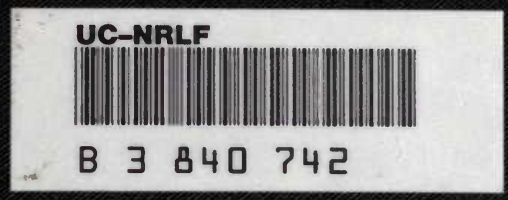



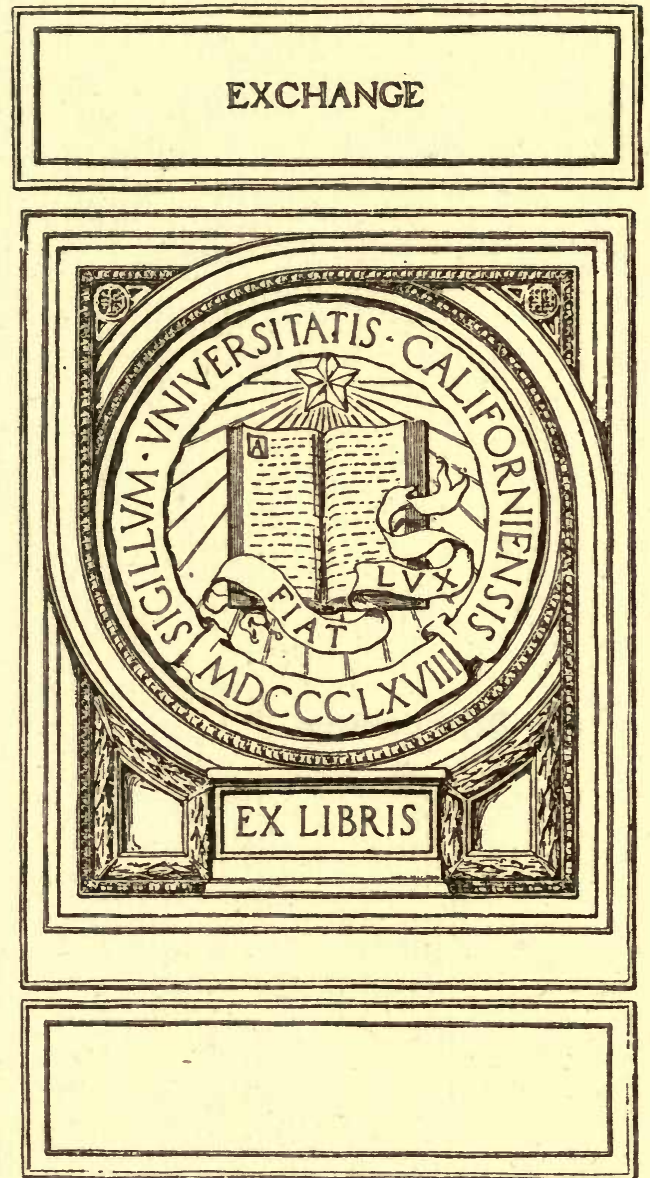




\title{
IOWA
}

GeologicalSurvey

\author{
Bulletin No. 5
}

\section{THE RODENTS OF IOWA}

BY DAYTON STONER

GeORge F. Kay, Ph. D., State Geologist

James H. LeES, Ph. D., Assistant State Geologist

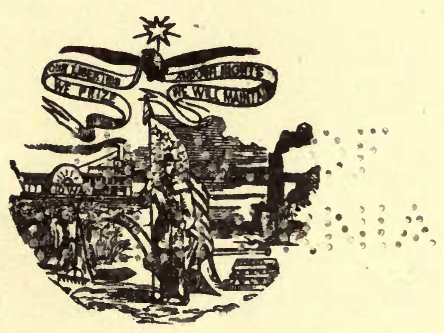

DES MOINES:

Published For Iowa Geological Survey 


\section{DES MOINES}

Robert Henderson, state printer

John M. Jamieson, State bindeR

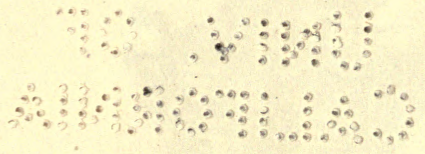




\section{LETTER OF TRANSMITTAL}

IOWA GEOLOGIGAL SURVEY

\section{To Governor William L. Harding and Members of the Geological Board:}

Gentlemen: I submit herewith a bulletin on the Rodents of Iowa which has been prepared by Mr. Dayton Stoner of the department of Zoology of the University of Iowa.

The rodents are the most numerous and the most widely distributed of all the orders of mammals, and since all of them are either herbivorous or omnivorous in diet they are of considerable importance to the agriculturist. Some of them are harmful and some of them are helpful in relation to crop production. It is necessary, therefore, that the farmer and gardener be able to discriminate between those rodents which are his friends and those which are his foes. Of the thirty-one species of rodents of Iowa, the most destructive species is the pocket gopher. Each year it is responsible for a loss of half a million dollars to the crops of the state.

The bulletin of Mr. Stoner describes the various rodents which are found in Iowa, their general characters, habits, distribution, economic importance, and the best methods of control of the most destructive species and the proper methods for encouragement of the most beneficial species.

Already the Iowa Geological Survey has published two bulletins which deal with subjects of economic interest relating to the Natural History of the state. One of these describes the Grasses of Iowa and the other the Weeds of Iowa. Both have been of great service to the people of the state. It is with the hope that the bulletin on the Rodents of Iowa will prove to be of equal value to the citizens of Iowa that it is now presented with the recommendation that it be published as Bulletin 5 of the Iowa Geological Survey.

I have the honor to be,

Yours sincerely,

George F. Kay,

State Geologist. 



\section{GEOLOGICAL BOARD.}

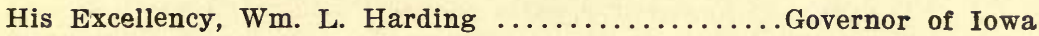

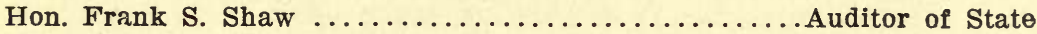
W. A. Jessup .................. President State University of Iowa

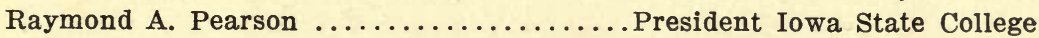

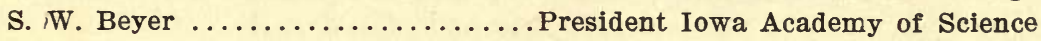

\section{ADMINISTRATIVE OFFICERS.}

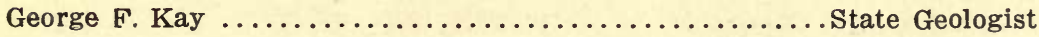

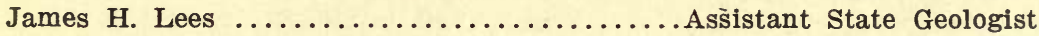
Nellie E. Newman Secretary 



\section{ILLUSTRATIONS}

Frgure 1. Map showing locality records of

1. Southern Flying Squirrel (Glaucomys volans volans)........ 18

Figure 2. Western Fox Squirrels a few days after birth. Photo from life by Frank C. Pellett. From "Our Backdoor Neighbors.". 19

Figure 3. Western Fox Squirrels ten days after the previous picture was taken. Photo from life by Frank C. Pellett. From "Our Báckdoor Neighbors." .............................. 21

FraURE 4: Map showing locality records of

1. Northern Gray Squirrel (Sciurus carolinensis leucotis).

2. Southern Red Squirrel (Sciurus hudsonicus loquax). ....... 24

Figure 5. Map showing locality records of

1. Gray Chipmunk (Tamias striatus griseus)............... 28

Figures 6 AND 7. The Plains Prairie-Dog (Cynomys ludovicianus).

(From U. S. Department of Agriculture.) .............. 41

Figure 8. The Plains Prairie-Dog (Cynomys ludovicianus).

(From U. S. Department of Agriculture.)............... 43

Figure 9. Plan of a Woodchuck burrow. (From Field Museum of Natural History.) ............................. 47

FIGURE 10. Pet Beavers. (From U. S. Department of Agriculture.) 51

Frgure 11. Northern White-footed Mouse (left). House Mouse (center). Prairie White-footed Mouse (right). Photo from life by Frank C. Pellett.................................... 53

Figure 12. The Brown Rat. (From U. S. Department of Agriculture, Bureau of Biological Survey.)...................... 54

Figure 13. Guillotine trap made entirely of metal. (From U. S. Department of Agriculture, Bureau of Biological Survey.) ....662

FigURE 14. Guillotine trap with wooden base and trigger plate. (From U. S. Department of Agriculture, Bureau of Biological Survey.)

FIGURE 15. Barrel trap: 1, with stiff paper cover; 2, with hinged cover; $a$ stop; $b$ baits. (From U. S. Department of Agriculture, Bureau of Biological Survey.) ........................... 64

FTgUre 16. Map showing locality records of

1. Northern White-footed Mouse (Peromyscus leucopus noveboracensis).

2. Prairie White-footed Mouse (Peromyscus maniculatus bairdi). 71

FIGURE 17. Field-Mouse skulls taken from pellets found under owl roost in Smithsonian tower, Washington, D. C. (From U. S. Department Agriculture, Bureau of Blological Survey.).......... 72

Figure 18. Prairie Harvest Mouse. Photo from life by Frank C. Pellett. 


\section{ILLUSTRATIONS}

Figure 19. Meadow Mouse caught in a guillotine trap. (From U. S. Department of Agriculture.) .................. 79

Figure 20. Map showing locality records of

1. Meadow Mouse (Microtus pennsylvanicus pennsylvanicus).

2. Prairie Meadow Mouse (Microtus ochrogaster ochrogaster).

3. Woodland Vole (Microtus pinetorum nemoralis) .......... 81

Figures 21 and 22. Apple trees five inches in diameter girdled by Prairie Mice (Microtus ochrogaster). The trees were saved by heaping up soil about the trunks to cover the injury. (From U. S. Department of Agriculture, Bureau of Biological Survey.) .... 88

FIgure 23. Apple tree killed by Prairie Mice. (From U. S. Department of Agriculture, Bureau of Biological Survey.) ........... 89

Figure 24. Root and trunk of apple tree from Laurel, Maryland, gnawed by Pine Mice. (U. S. Department of Agriculture, Bureau of Biological Survey.) ........................... 92

Figure 25. Pine tree killed by Pine Mice. (From U. S. Department of Agriculture, Bureau of Biological Survey.)........... 94

Figure 26. The Muskrat. (From U. S. Department of Agriculture, Bureau of Biological Survey.).................. 98

F'igure 27. Map showing locality records of

1. Goss's Lemming Mouse (Synaptomys cooperi gossii).

2. Prairie Harvest Mouse (Reithrodontomys megalotis dychei.)..107

Figure 28. Faces of Pocket Gophers, showing pouches and incisors.

(From U. S. Department of Agriculture.) .................. 109

Figure 29. Apricot tree killed by Pocket Gopher. (From U. S. Depart-

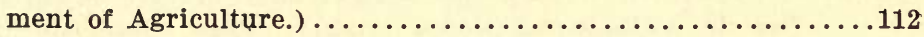

Figure 30. A section of the Apricot tree shown in the preceding view. The injury was under ground. (From U. S. Department of

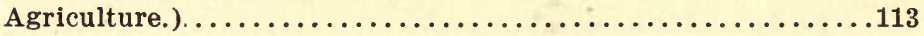

Figure 31. Root of Apple tree gnawed by Pocket Gopher. Root knots prominent. (From U. S. Department of Agriculture.) ......114

Figure 32. Map showing locality records of

1. White-tailed Jack Rabbit (Lepus townsendi campanius.)

2. Great Plains Jack Rabbit (Lepus californicus melanotis.).....132

Figure 33. Young Cottontail at about the time of leaving nest. Photo from life by Frank C. Pellett.......................

Figure 34. Cottontail Rabbit in its "Form". (From U. S. Department of Agriculture, Bureau of Biological Survey.).............135

Figure 35. Apple tree killed by Rabbits. (From U. S. Department of Agriculture, Bureau of Biological Survey.) ..............136

Figure 36. Details of a Wellhouse Rabbit trap. (From U. S. Department of Agriculture, Bureau of Biological Survey.) ............138 


\section{GONTENTS}

Introduction

Part I. Description of Iowa Rodents with Discussions of

Habits, Distribution, Economic Importance, Methods

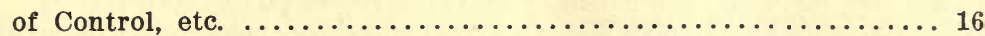

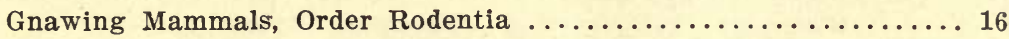

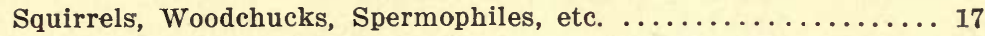

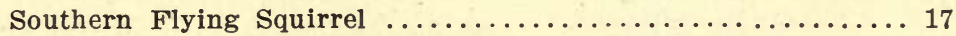

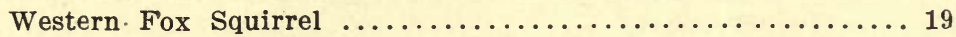

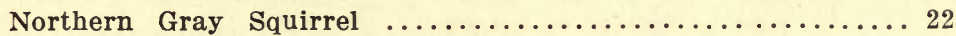

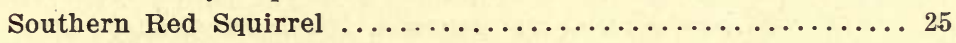

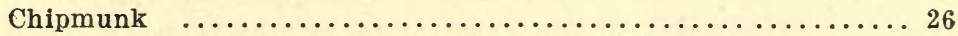

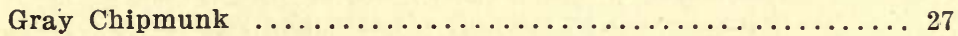

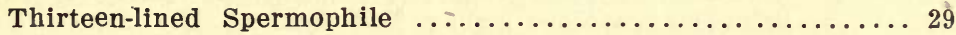

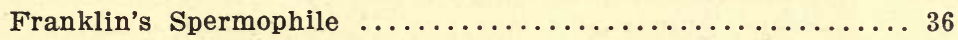

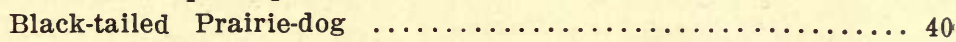

Southern Woodchuck ....................... 45

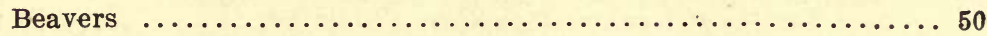

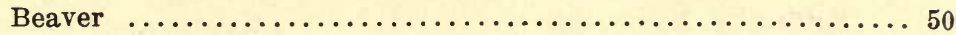

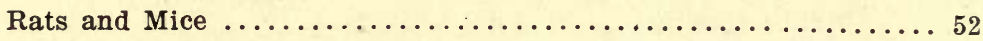

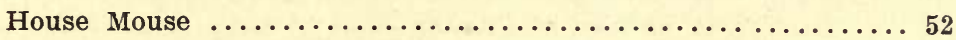

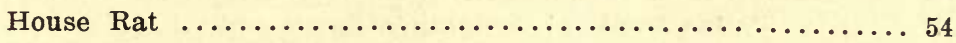

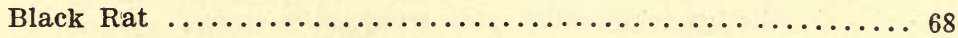

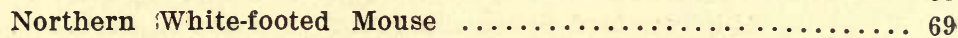

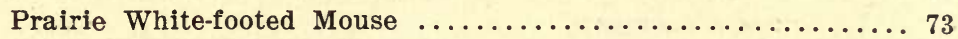

Prairie Harvest Mouse . . . . . . . . . . . . . . . 76

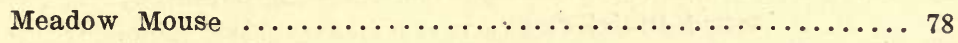

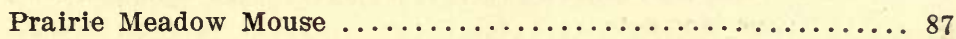

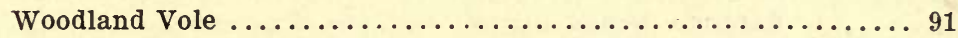

Common Muskrat .............................. 96

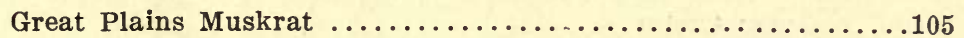

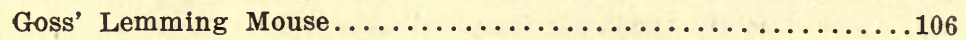

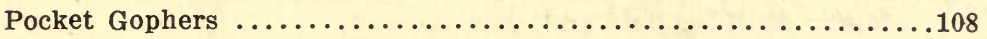

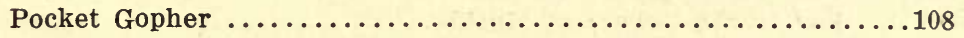

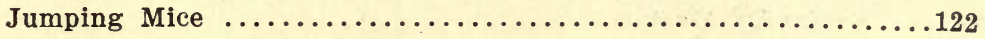

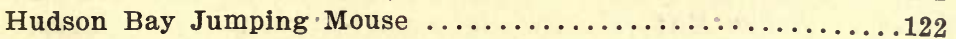

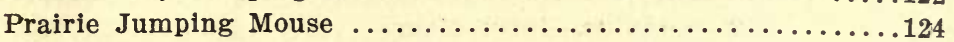

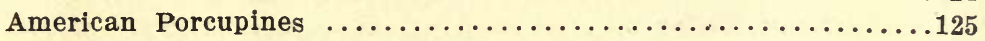

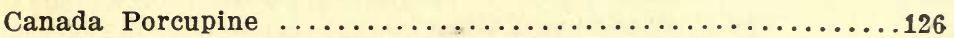

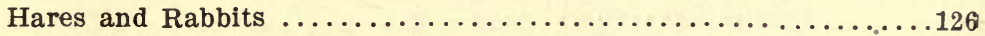

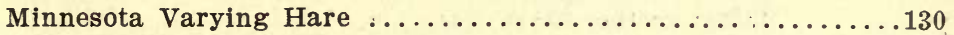

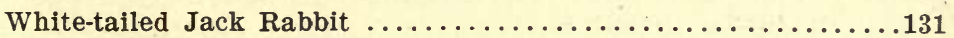

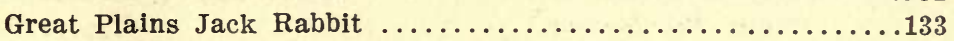

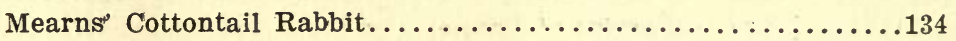


Part II. Keys to the Suborders, Families, Genera and

Species of Iowa Rodents . . . . . . . . . . . . . . . . . . 141

Order Rodentia, Gnawing Mammals ..........................

Key to Suborders of Rodentia . . . . . . . . . . . . . . . . 141

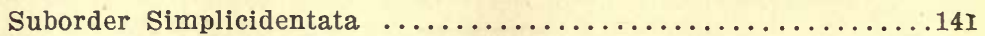

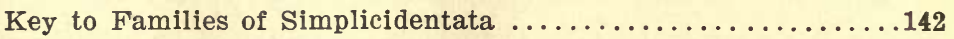

Family Sciuridæ, Squirrels, Woodchucks, etc................

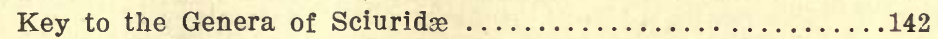

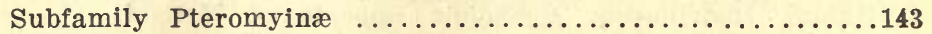

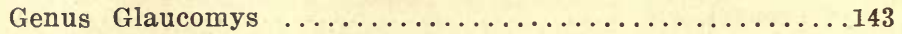

Glaucomys volans volans, Southern Flying

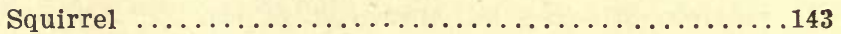

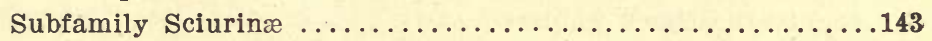

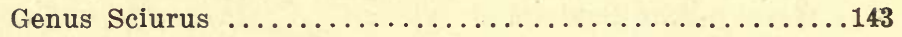

Key to Species of Sciurus ......................

Sciurus carolinensis leucotis, Northern Gray

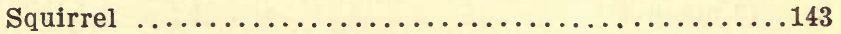

Sciurus niger rufiventer, Western Fox Squirrel.........143

Sciurus hudsonicus loquax, Red Squirrel ...........143

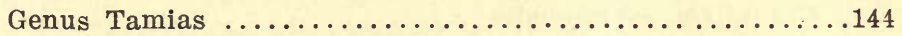

Key to species of Tamias ........................

Tamias striatus striatus, Chipmunk ..............144

Tamias striatus griseus, Gray Chipmunk............144

Subfamily Marmotinæ ......................

Genus Citellus ............................

Key to Species of Citellus .....................

Citellus franklini, Franklin's Spermophile...........144

Citellus tridecemlineatus tridecemlineatus,

Thirteen-lined Spermophile ....................

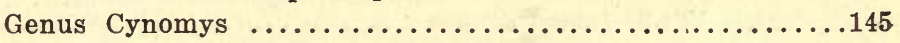

Cynomys ludovicianus ludovicianus, Black-

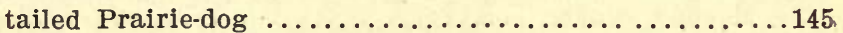

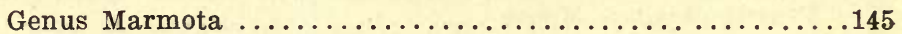

Marmota monax monax, Southern Woodchuck........145

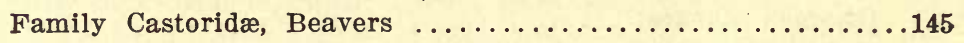

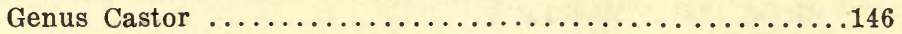

Castor canadensis canadensis, Beaver.............146

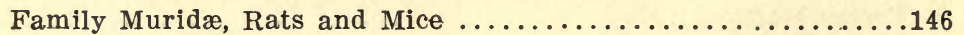

Key to the Genera of Muridæ ...................... 146

Subfamily Murinæ .........................

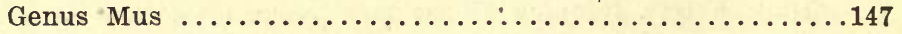

Mus musculus, House Mouse ................147

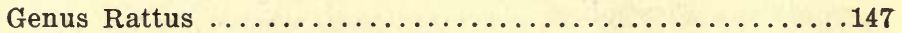

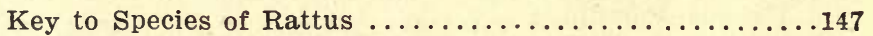

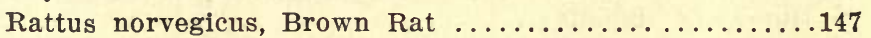

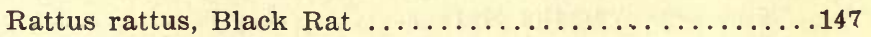

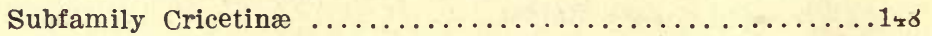

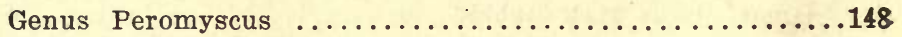

Key to Species of Peromyscus .................. 148 
Peromyscus maniculatus bairdi, Prairie White-

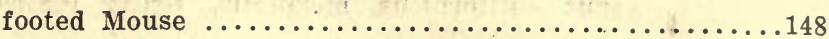

Peromyscus leucopus noveboracensis, Northern

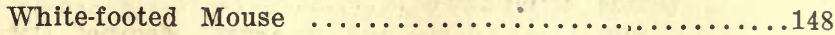

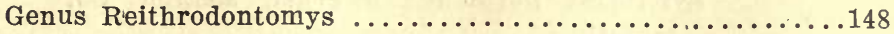

Reithrodontomys megalotis dychei, Prairie

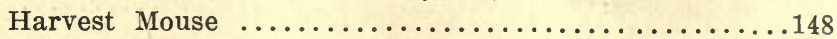

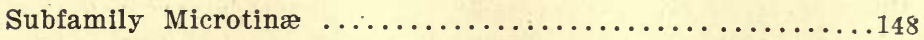

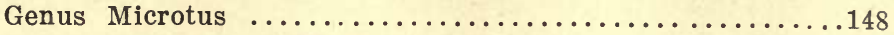

Key to Species of Microtus ....................... 149

Microtus pinetorum nemoralis, Woodland Vole..........149

Microtus ochrogaster ochrogaster, Prairie

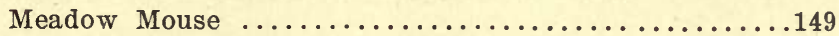

Microtus pennsylvanicus pennsylvanicus,

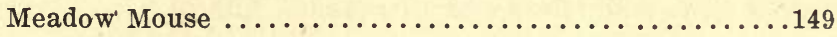

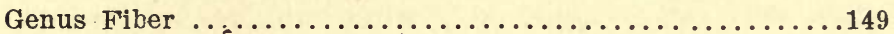

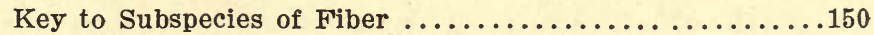

Fiber zibethicus zibethicus, Common Muskrat........150

Fiber zibethicus cinnamominus, Great Plains

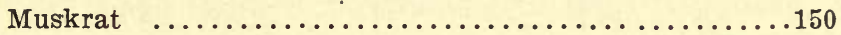

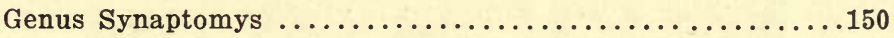

Synaptomys cooperi gossii, Goss' Lemming

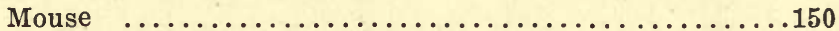

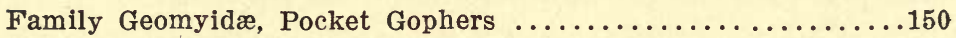

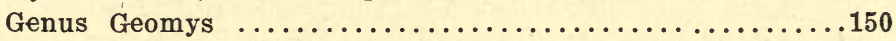

Geomys bursarius bursarius, Pocket Gopher.........150

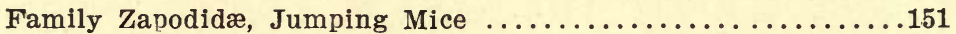

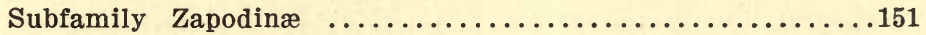

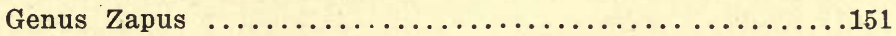

Key to Subspecies of Zapus ......................

Zapus hudsonius hudsonius, Hudson Bay

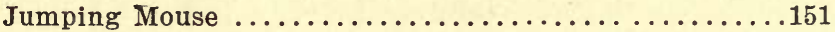

Zapus hudsonius campestris, Prairie Jumping

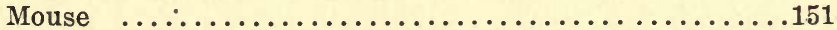

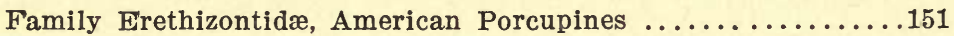

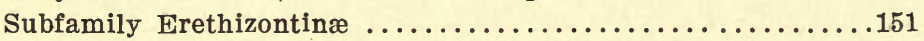

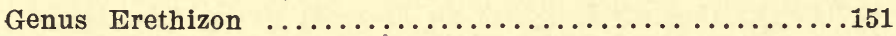

Erethizon dorsatum dorsatum, Canada Porcu-

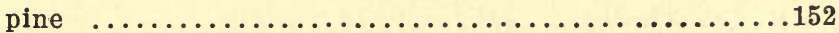

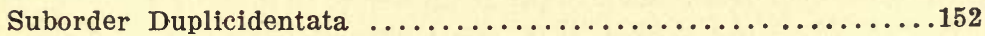

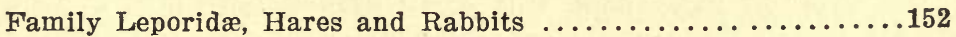

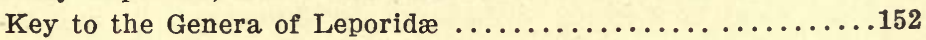

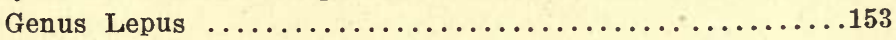

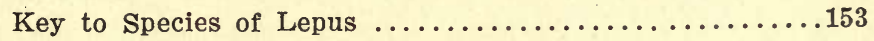

Lepus americanus phæonotus, Minnesota

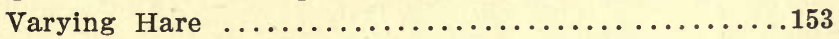

Lepus townsendi campanius, White-tailed Jack

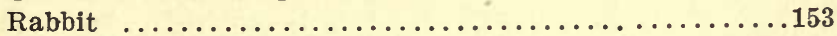


Lepus californicus melanotis, Great Plains

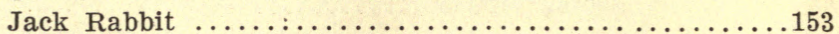

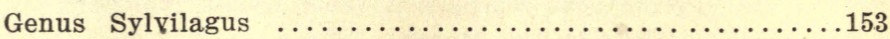

Sylvilagus floridanus mearnsi, Mearns' Cot-

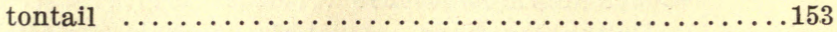

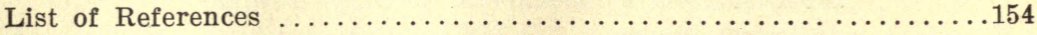

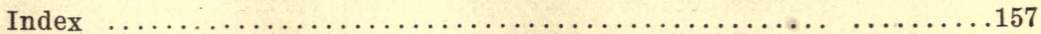




\section{THE RODENTS OF IOWA}

\section{Introduction.}

The present bulletin is offered to the people cf the state with the object of giving such information as is available upon a group of animals which is of considerable economic importance. The material contained in Part I of the bulletin consists of brief diagnostic descriptions of the various rodents known with certainty to occur or to have occurred within the borders of the state, together with something of their habits, distribution, economic importance and also methods of control where such are deemed desirable. Most of the measurements included in the descriptions are given in inches. To avoid small and inconvenient fractions of inches some small measurements are given in millimeters, a millimeter being equivalent to approximately 1-25 of an inch. The measurements given for the various forms indicate the average; so that specimens may be found which are somewhat below or above the figures indicated. These measurements are taken in the following manner:

Total length.-Distance from tip of nose to tip of tail vertebræ not including the hairs.

Tail vertebrae or tail.-Distance from the point where the tail joins the body to tip of tail, not including the hairs.

Hind foot.-Distance from heel to end of longest claw.

In order to facilitate ready determination of groups and species, simple keys based, for the most part, upon external characters are added, and will be found in Part II of the bulletin. It is.hoped that these identification tables will be found useful to individuals as well as in schools where study of this nature can profitably be taken $n$, and it is further hoped that this paper may be of service in creating among the people of the state a greater interest in the wild life about them.

The entire paper has been prepared with special reference to the needs of the lay public, and an attempt has been made to make it as non-technical as possible without sacrificing too much that is seriously and strictly scientific.

A further attempt has been made to give special consideration to those rodents which are of economic importance to us. Any 
animal is worthy of consideration from an economic standpoint if it is sufficiently abundant and is in some way or other detrimental to man's best interests. Nature seeks to maintain a proper "balance" among all the forms of life on the giobe, but when man steps in and interferes with this great plan some penalty must often be paid. When the numbers of any species of animal are maintained at about the normal, the damage done is so slight as to be almost negligible. If, however, the numbers of any species, through some cause or other, reach a point far above normal, their habits and even their presence make them worthy of consideration. The kind and quality of the food destroyed are matters rather of secondary importance. Since many of the rodents are prolific breeders and most of them are also hearty eaters, methods of control and remedial measures of various kinds are often of considerable value.

In the main, the system of classification and arrangement of species here adopted is that employed by Cory in "The Mammals of Illinois and Wisconsin.", In some cases, however, a later system has been followed. Attempt has not been made to include all the forms which "possibly" or "probably" occur within the state, but for the most part, only those appear of which certain and authentic records are available. For this reason and because of the fact that many of the species have been split up into a greater or lesser number of subspecies and geographic races, it is possible that some forms not mentioned in these pages should be added, but the main object of the paper will not have been defeated on this account. In the preparation of this bulletin rata have been drawn freely from Cory's work and from the various papers published by the United States Biological Survey. Other articles which have proved of value are included in the list of references. Under every species and subspecies reference is given to the first publication of the specific or subspecific name.

During the preparation of the present work various parts of the state have been visited for the purpose of observation and the securing of material. In addition, the assistance of others has been invited, so that the list of those who have contributed in some way or other is rather a long one. The following persons have thus aided materially in the securing of specimens from which many locality records were obtained:

\footnotetext{
${ }^{1}$ Cory, Charles B. The Mammals of Illinois and Wisconsin: Field Mus. Nat. Hist., Pub. 153, Zool. Ser. XI, 1912.
} 
J. K. Alter, Wayland; *B. H. Bailey, Cedar Rapids; Paul Bauman, Melvin; Virgil Bearden, Thayer; Merrill Deal, Waukon; H. R. Dill, Iowa City; Kenneth Dunlop, Jefferson; Marcus Fiene, Ocheyedan; Joe Gibson, Corning; Porter Green, Garrison; Sanford Griswold, Charles City; W. F. Kंubichek, Iowa City; J. R. Martin, Tama; Marion Mincks, Ottumwa; Henry Schroeder, Vinton; J. A. Spurrell, Wall Lake; A. O. Thomas, Iowa City.

Specimens have been examined in the Museum of the State University of Iowa, the Coe College Museum, the Grinnell College $\mathrm{Mu}$ seum, and the Iowa State Museum at Des Moines. The sources of other material and information are given in the text.

In addition, data of various kinds have been obtained from farmers, hunters, and trappers while the county auditors of the various counties visited have given information and notes on bounties. All have been uniformly courteous and sympathetic.

Determinations of specimens have been made and verified by officials of the United States Biological Survey through the courtesy of Mr. E. W. Nelson, Chief of the Survey. Various points of difficulty have, from time to time, been referred to workers in the Survey, and the response has always been prompt and gratifying. Certain of the figures herein published have also keen furnished by the Division of Publications, United States Department of Agriculture.

Mr. Frank C. Pellett of Atlantic has furnished notes, specimens, and data relating to some of the forms discussed; and several of the photographs herein included are the result of his work.

Miss Jane E. Roberts, Librarian at the State University of Iowa, has made it possible for me to have access to various books and papers not found in the University Library, but which were essential to the prosecution of this work.

Especial thanks are due Professors C. C. Nutting and H. F. Wickham, of the Department of Zoology, State University of Iowa, for helpful suggestions and criticism during the preparation of this paper.

Dr. James H. Lees, Assistant State Geologist, has offered suggestions and granted many courtesies.

To Professor G. F. Kay, Director of the Iowa Geological Survey, I desire to express my appreciation for having made possible this bulletin and for continued encouragement and interest during its preparation.

*Deceased. 


\section{PART I. \\ DESCRIPTIONS OF IOWA RODENTS. \\ GNAWING MAMMALS. \\ Order RODENTIA.}

The order Rodentia is the largest and most widely distributed of the mammalian orders; and, due to the fact that all the members are either herbivorous or omnivorous in diet, it forms a group of considerable economic importance, especially to the agriculturist. In such a large group as this it is but natural to expect great variety in form and habits. Some, such as the muskrat, are semiaquatic; others, such as the pocket gopher and the spermophiles, are more or less fossorial and live in underground burrows; still others, such as the squirrels, are arboreal; while many representatives of the group are terrestrial.

In spite of this great diversity in habits, certain peculiarities are characteristic of the group. A rodent may at once be distinguished from any other mammal by the large, chlisel-like front teeth (incisors), the absence of canines, and the long toothless space between the incisors and the molar series. There is never more than a single pair of lower incisors; and in only one group, the Duplicidentata, the suborder containing the hares, rabbits and their allies, is the number of upper incisors greater than the lower. In the Duplicidentata a second pair of small incisors is found situated immediately back of the large normal front pair. Due to the fact that these incisor teeth are furnished with enamel on their anterior faces and also that these teeth continue growing as they become worn away, a sharp, chisel-like edge is maintained which is very effective in cutting. Both upper and lower incisors are regularly curved, the curvature of the upper pair being somewhat greater than that of the lower pair although the tips of these teeth oppose one another.

The mouth is divided into two cavities which communicate by a constricted orifice in the space between the incisor and molar teeth, so that the two cavities each contain one of these sets of teeth; the hairy skin of the face is continued inward behind the incisors. Such an arrangement prevents substances not intended for food 
from being taken into the mouth, and is thus effective when the posisessor is gnawing some obstruction.

Thirty-one forms of rodents have been recorded from Iowa and are discussed in this paper. These represent six families, five of which belong to the suborder Simplicidentata.

\section{SQUIRRELS, WOODCHUCKS, SPERMOPHILES, ETC.}

\section{Family SCIURIDA.}

This is a family of wide distribution and high specialization, and in Iowa some of the forms are so abundant and destructive as to be worthy of consideration in their economic relations. They vary in form and habits from the arboreal flying squirrel fitted for semi-aerial progression, to the terrestrial and fossorial woodchuck. Some forms hibernate in our latitude. Many of the forms are more or less brilliantly colored, reds, yellows, and browns predominating.

\section{SOUTHERN FLYING SQUIRREL. FLYING SQUIRREL.}

\section{Glaucomys volans volans (Linnæus).}

[Mus] volans Linnæus, Syst. Nat., X ed., I, 63, 1758.

Description.-Upper parts grayish or grayish brown, more or less shaded with russet, with the upper surface of tail slightly darker; most of the upper surface of flying membrane dark brown; under parts white, the hairs entirely white at the bases; under surface of tail buffy or buffy white; fur very smooth and soft. In winter, the coloration is similar, but the upper parts are more deeply tinged with grayish brown.

Measurements.-Total length, 9.25 inches, tail vertebræ, 3.90 inches; hind foot, 1.20 inches.

Habits, Distribution, Etc.-This little squirrel seems to be fairly common in rather heavily wooded areas throughout the state, but is more abundant in the eastern half. It is not often seen by the average person because of its nocturnal habits, though it sometimes comes out in late afternoon. One of its common methods of progression is to climb to the top of a high tree and then to launch forth into the air when, by means of the expanded integument at the sides of the body, it is able to glide to the lower branches or trunk of a tree often some distance away. And thus the animals, while they are not able to "fly" can glide from a higher to a lower point. 
Flying squirrels are more or less gregarious and make their nests of moss and leaves in hollow trees. Often, when such a tree is disturbed, several of these little gray fellows will scamper out and sail away to another tree. Many abandoned red-bellied or red-headed woodpeckers' nests are inhabited by families of these squirrels, and a single tree may contain several families. The young are from four to six in number and are said to make interesting pets.

Contrary to some observations it is not probable that flying squirrels really hibernate during the winter, although they do remain in their nests during severe weather; but their sleep is easily broken, and upon being aroused from the nest they are apparently as active as ever.

The food of flying squirrels consists for the most part of seeds, nuts, acorns, corn, insects, and sometimes of birds' eggs and even of the young birds themselves. However, they can scarcely be said to be sufficiently plentiful in any locality to cause serious harm and should not be slaughtered indiscriminately. Neither should it be considered good form to hold as captives and merely for the amusement of the possessor any of these handsome little animals.

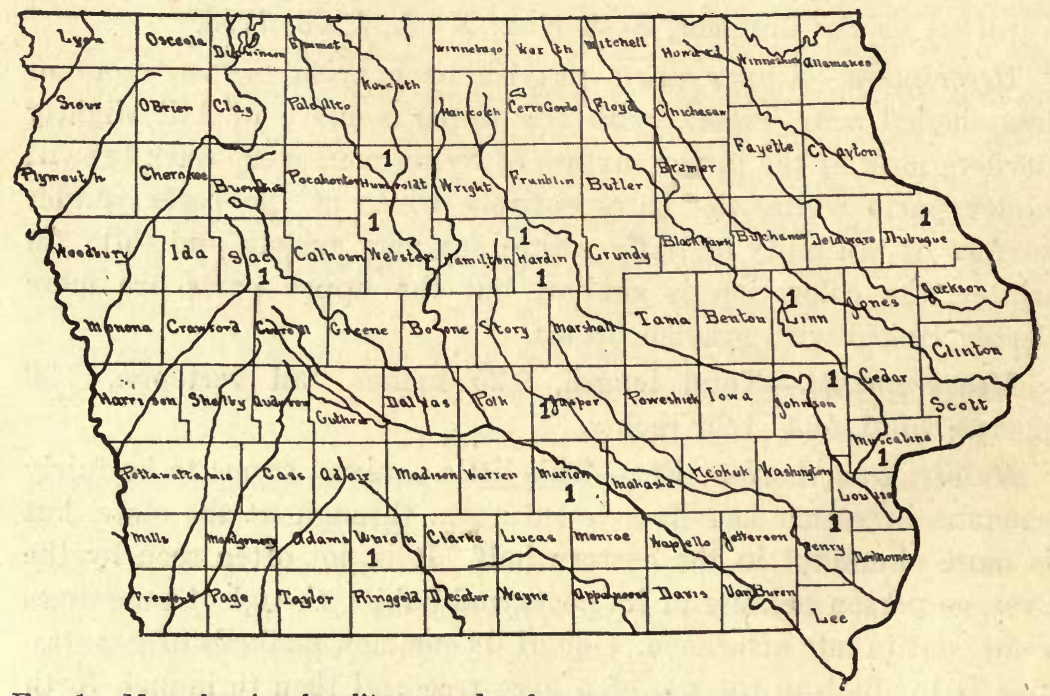

Fig. 1.-Map showing locality records of-

1. Southern Flying Squirrel (Glaucomys volans volans).

Specimens are at hand from the following localities: Iowa City, Wayland, Knoxville, Wall Lake, Ft. Dodge, Iowa Falls, Humboldt, Moscow, Steamboat Rock, Dubuque, Thayer, Colfax, Cedar Rapids. 
In early days, according to the best information obtainable, this species was common in many localities where it is now scarce. Towards the extreme western part of the state the species is reported as rare or absent. With the cutting off of the heavily timbered areas in many parts of the state the distribution of the flying squirrel has become much more restricted than formerly and its numbers have correspondingly diminished.

\section{WESTERN FOX SQUIRREL. FOX SQUIRREL.}

Sciurus niger rufiventer (Geoffroy).

Sciurus rufiventer Geoffroy, Cat. Mamm. Mus. d'Hist. Nat., 176, 1803.

Description.-General color, upper parts tawny brown with darker brown intermingled; tail mixed black and rufous, the tips of the hairs tawny or rufous; ears rufous brown; under parts pale rufous or yellowish brown.

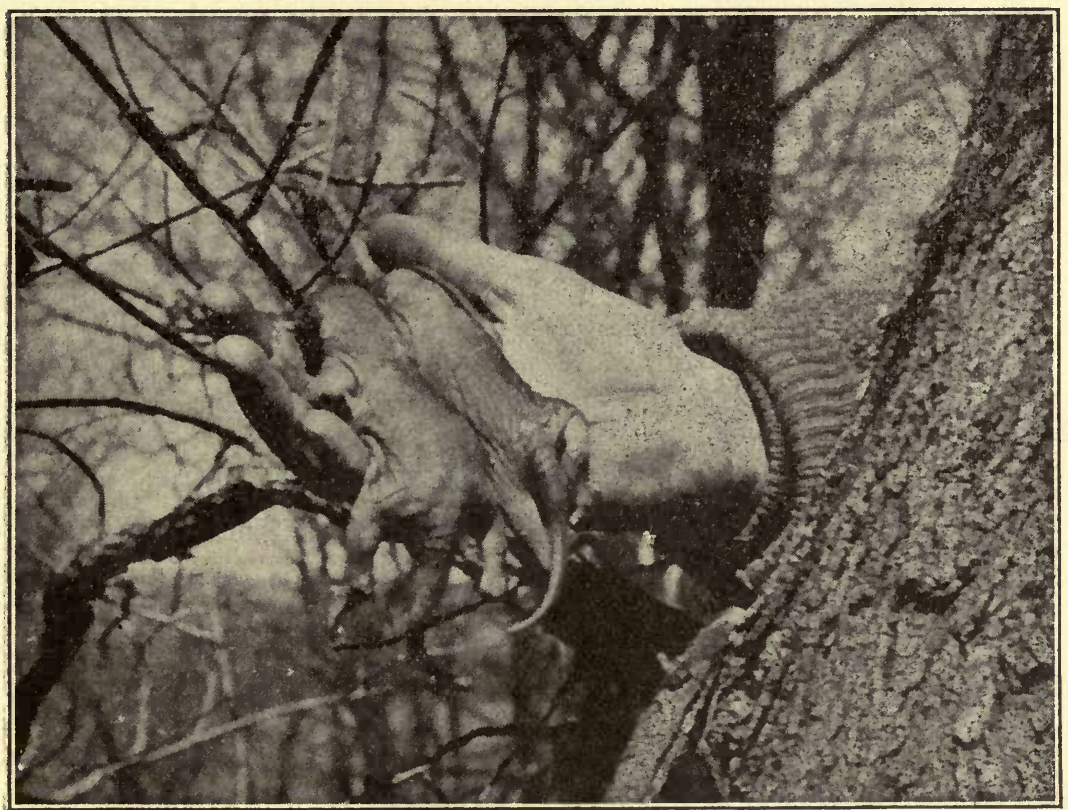

FIG. 2.-Western Fox Squirrels a few days after birth. Photo from life by Frank C. Pellett. From "Our Backdoor Neighbors."

Measurements.-Total length, 22.00 inches; tail vertebræ, 9.75 inches; hind foot, 3.00 inches. 
This is a very variable form and one for which a single description will not fit every specimen. Some individuals are entirely black, while others present a mixture of rufous and tawny with all sorts of intermediate variation. Usually; however, the solor above is tawny gray-brown with yellow or pale orange below; the hairs of the tail are rufous more or less mixed with black, usually tawny or rufous at the tips and with the under surface bright ferruginous. The gray squirrel is the only other Iowa form which is likely to be mistaken for the present species, which may at once be distinguished from that form by the tawny or rufous tips to the hairs on the tail and the presence of but four teeth of the molar series on each side of both jaws. In addition, the gray squirrel averages about three to four inches smaller than the present species.

Habits, Distribution, Etc.-This the largest of our arboreal squirrels inhabits the more or less heavily timbered districts of the state and is much less often found in open ground. It has become abundant in many of our parks and even on the lawns in cities, where its antics afford interesting diversion for many people. It is a more solitary species than the gray squirrel, and seldom are more than two adults found living together. Usually in the summer and fall the old males go about by themselves. The fox squirrel often builds several nests, usually in tall trees but in some cases not more than fifteen to twenty feet from the ground. These nests are composed of leaves and sticks placed in the fork of the tree. The nest materials are usually cut from the tree in which the nest is made, although adjoining trees may be visited for the securing of this material. After the young are able to shift for themselves they either leave the nest of their own accord or are driven away by the mother, and for a time lead more or less of a wanderer's existence, building nests for themselves as the occasion arises and perhaps abandoning them again in a short time. Sometimes the fox squirrel chooses a hollow tree as an abode; but it does not require such a domicile in which to rear its yourg, as the author has personal knowledge of young being reared in nests composed of leaves and twigs. Usually two or three young are produced at one birth although the number varies from one to five. The young are born blind and naked and do not assume a squirrel-like appearance until about three weeks old. It seems probable that in some instances two litters are brought forth in a season. 
The food of the fox squirrel is composed of nuts, acorns, seeds, and the buds of trees, particularly of maple and elm. In late summer and early fall it eats the fruit of various thorn and berry bushes and sometimes also destroys insects. It has been observed to snaw the bark from dead trees in order to secure beetles and their larvæ. In cities and towns where the food supply is rather limited it sometimes visits granaries and destroys or carries away considerable grain. The writer has seen an adult squirrel while carrying a good-sized ear of corn, ascend a tree without much difficulty. In many localities this squirrel has been reported as destroying birds' nests and eggs; and while there is some evidence to corroborate this, the habit does not seem sufficiently widespread and serious to require drastic measures of control. Sometimes by eliminating a single pair of squirrels or even a single individual from a restricted locality the difficulty will be solver.

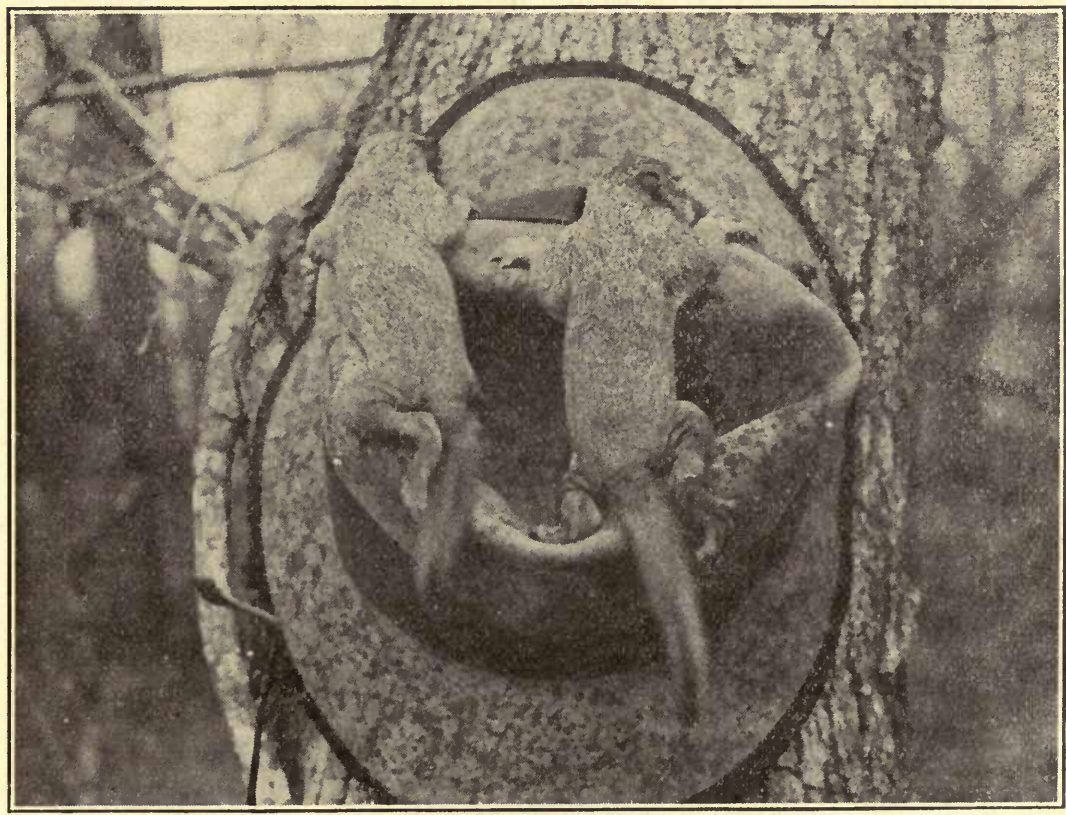

Fig. 3-Western Fox Squirrels ten days after the previous picture was taken. Photo from life by Frank C. Pellett. From "Our Backdoor Neighbors."

In Dubuque county a member of the board of supervisors informed the writer that this species destroyed about five acres of growing corn on cne farm where the shooting of these rodents was prohibited. However, this is the only instance of serious damage by this animal to which the writer's attention has been called. 
The fact has also been pointed out by some, that "squirrels," probably including the present species, seek out and feed upon acorns in which living larvæ of the Oak Weevil (Balaninus sp.) are developing. In such cases the fox squirrel, along with others, acts as an element in the control of this insect pest. Considering its habits in general, this squirrel should be protected and encouraged to nest in our parks and woods; and the toll that it may exact in the destruction of a few birds must be included in the great scheme of Nature for maintaining a proper balance among animals.

The fox squirrel is reported as common or abundant by observers in practically all parts of the state, but the numbers diminish somewhat towards the extreme western and eastern portions. In almost any locality where the woods are not too dense these animals are most abundant. Of late years a general sintiment toward the protection of this species has sprung up with the result that in our public parks and even along city streets which are fairly well furnished with shade trees the fox squirrel is not uncommon and often breeds. In eastern Iowa, particularly in northeastern Iowa, considerable tracts of dense woodland still remain, and such are not frequented so much as are the central prairie woodlands. Thence toward our western border even sparsely wooded areas are much less frequent, so that this feature of the topography also seems to have some effect upon the distribution of this animal. John Spurrell of Wall Lake writes that this form first appeared in that locality about 1904, so that the wave of dispersal seems to be towards the west. At Sibley, in Osceola county, this form is reported to have appeared only within the last three years.

If a list of locality records were prepared for this species it would probably include every county in the state so that a complete record would seem superfluous. It has been reported in practically all of the sixty-two counties visited during the preparation of this paper. Specimens are at hand also from many localities.

\section{NORTHERN GRAY SQUIRREL. GRAY SQUIRREL.}

Sciurus carolinensis leucotis (Gapper).

Sciurus leucotis Gapper, Zool. Journ., V, 206, 1830.

Description.-Summer: General color above grayish with a faint tinge of brownish along middle of back, at the sides of the rody just behind front legs, on the ears and about the head and face; under parts white or whitish, sometimes with a rusty tinge on back 
and chest; hairs of tail yellowish at base followed by blackish and tipped with white. Winter: Above silvery gray, the bases of the brown hairs on the head entirely or almost concealed.

Measurcments.-Total length, 19.75 inches; tail vertebræ, 9.00 inches; hind foot, 2.70 inches.

This is another form which varies markedly in color from entirely black to gray with many intergradations; sometimes also albino specimens are found. In the Museum of the State University of Iowa is a mounted specimen with the under parts and sides of the head entirely black. This squirrel may be separated from its closest ally in our fauna by the fact that it usually possesses five teeth of the molar series on either side of the upper jaw; two of these tceth are premolars and three are molars; in addition, the hairs of the tail are tipped with white.

Habits, Distribution, Etc.-The northern gray squirrel seems to prefer the more heavily wooded regions of the state, and towards the extreme east and northeast is reported as more common than the fox squirrel. In these regions densely timbered areas are not uncommon, while farther west many of the extensive timbered sections have been destroyed-and along with them the gray squirrels. At Ottumwa and Albia this species was formerly rather abundant, but the numbers have been much lessened of late, as the miners have killed a great many for food.

It is seldom that in restricted localities the gray squirrel and the fox squirrel are found in equal numbers, the advantage in this respect being usually with the former. The gray squirrels are the more pugnacious of the two and will not tolerate the presence of the fox squirrels, making life so miserable for them that they soon abandon the locality.

This is one of the more gregarious species of our arboreal squirrels and considerable numbers of them in some instances occupy a limited area. In early days the species was more or less migratory; but while it may at the present time migrate somewhat, the numbers have been so greatly reduced that attention is not directed to the phenomenon. These migrations occurred at irregular intervals and were probably undertaken for the purpose of securing a more adequate food supply.

The northern gray squirrel nests in hollow trees and in habitations constructed of leaves, twigs, and bark which are placed among the branches. These exterior nests have a roof and an en- 
trance from the side. In many cases two litters of young are produced in a season, the first usually early in April and the serond in late August or early September. A litter usually consists of from three to five young, which are born naked.

Although this squirrel remains in a quiescent or semi-dormant condition often for long periods of time during severe winter weather, it does not hibernate in the true sense of the word. When weather conditions become more favorable it comes out, runs abour and feeds, and upon the appearance of another period of cold again enters its nest.

The food of the gray squirrel is very similar to that of the fox squirrel and both indulge in the same habit of burying nuts and acorns in holes in the earth. It is not probable that squirrels "remember" where the morsel has been placed, but probably depend upon a keen sense of smell for again finding the buried nuts. Sometimes they burrow beneath the snow to reach the buried food, while many times, no doubt, they never appear again at the spot where a nut or acorn has been hidden.

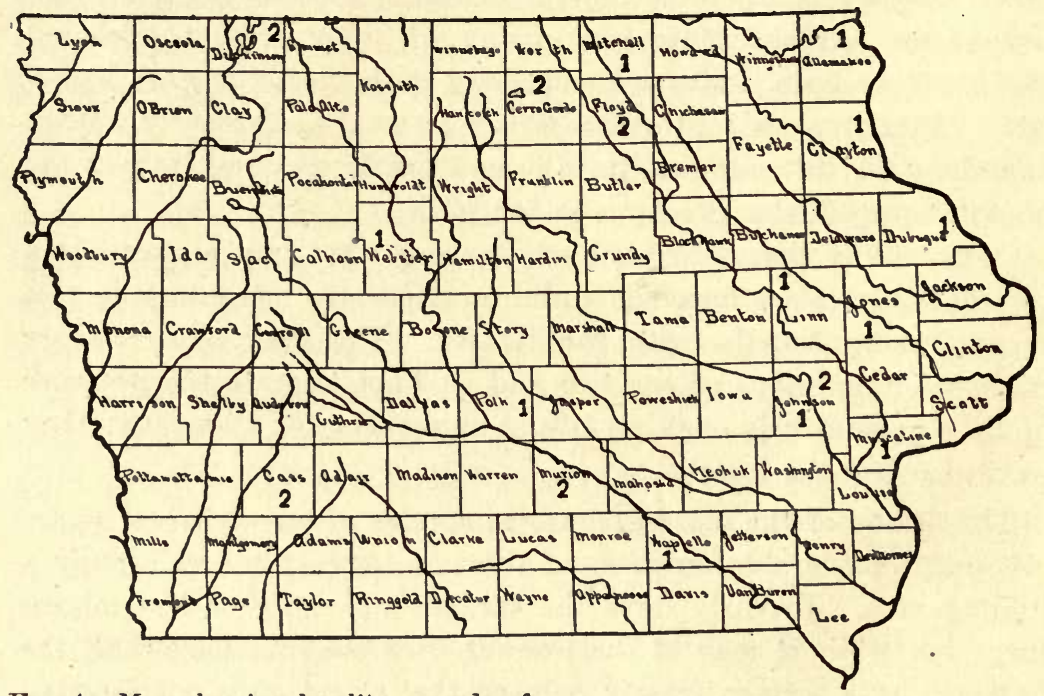

FIG. 4. Map showing locality records of-

1. Northern Gray Squirrel (Sciurus carolinensis leucotis).

2. Southern Red Squirrel (Sciurus hudsonicus loquax).

The northern gray squirrel is reported as abundant nowhere in the state except in the northeastern portion. At Waukon, McGregor, and Dubuque it is more abundant than the fox squirrel. In localities farther to the west individuals are met with occasionally, 
but with the cutting over of the heavily timbered areas and the more or less wanton destruction of these animals the numbers are becoming much reduced. At Iowa City this form is much less common now than fifteen years ago. Towards the southcentral part of the state it is seldom seen while towards the northwest in Clay county it is reported as fairly common. Other localities from which specimens have been sent or where the species is reported as being at least common are: Muscatine, Oxford, Monticello, Fort Dodge, Paralta, Des Moines, and Osage.

\section{SOUTHERN RED SQUIRREL. RED SQUIRREL. CHICKAREE.}

\section{Sciurus hudsonicus loquax (Bangs.)}

Sciurus hudsonicus loquax Bangs, Proc. Biol. Soc. Wash., X, 161, 1896.

Description.-Summer: Upper parts reddish brown; a conspicuous black lateral stripe separates the color of the back from the white under parts, which on some specimens are tinged with rusty; tail mostly deep rufous brown, the terminal hairs blackish at tips; front of fore legs and upper surface of hind feet yellowish. Winter: A broad median dorsal stripe of bright rufous brown or orange rufous extends from between ears to tip of tail; sides olive gray; lateral stripe wanting or but faintly indicated; under parts grayish white; under surface of tail olive gray, the hairs on the sides and tip of tail with a subterminal band of black and tipped with tawny. Soles of feet furred.

Measurements.-Total length, 12.50 inches; tạil vertebræ, 5.00 inches; hind foot, 1.85 inches.

In summer the red squirrel is of a reddish brown color with the under parts white or grayish white, while in winter the upper parts are grayer with the bright rufous stripe down the back and the under parts also grayer. The tail is somewhat flattened; in winter the ears are tipped with long hairs, and the soles of the feet bear soft hair.

Habits, Distribution, Etc.-The red squirrel is most at home in the well wooded areas of the eastern half of the state, but occurs also though not so commonly in the forests of western Towa. Usually it makes its home in a hollow log or tree, but sometimes a deserted woodpesker hole is chosen for a habitation. In rare 
cases it makes its nest in a hole in the ground and in perhaps equally rare cases it constructs a nest of leaves and twigs among the branches of trees. Although it does not hibernate in winter, it is not active during severe weather; when the temperature has moderated somewhat, even though the ground is covered with snow, it comes out as usual.

Usually four or five young are produced at a single birth; they are born in April.

The red squirrel may be classed as an almost omnivorous feeder, but it is seldom so abundant in any locality as to cause serious damage to stored food or grain. In places where it is abundant, it may make rare attacks on cornfields which are planted along the edges of woods, but the writer has heard of no damage of this sort in the state. Among the kinds of food of which it is particularly fond may be mentioned acorns, nuts of various kinds, wild fruits and berries, mushrooms and insects; birds' eggs and sometimes even their young are eaten. Many other things might be included in the list. In autumn this squirrel stores away quantities of acorns, nuts, seeds, etc., for use during the winter and in some localities it is reported to have carried off the stores and food of both the fox squirrel and the gray squirrel.

While this form is found more particularly in the eastern half of the state, its distribution is not thus limited; for it may be met with in almost every wooded area of any size within the borders of the state. Towards the south it seems to be much less common and here the wooded areas are also much less limited in extent. Among the definite locality records may be mentioned Clear Lake, Knoxville, Iowa City, Lake Okoboji, Charles City, Atlantic. See also the map on page 24 .

The Minnesota chickaree (Sciurus hudsonicus minnesota Allen), formerly considered a valid geographical race has now been proved to be only a lighter color phase of the red squirrel and hence is not included in this paper.

\section{CHIPMUNK. STRIPED CHIPMUNK.}

Tamias striatus striatus (Linnæus).

[Sciurus] striatus Linnæus, Syst. Nat., X ed., I, 64, 1758.

Description.-Upper parts rusty brown with flanks and limbs pale yellowish brown; deep chestnut rufous on the rump; back 
with five black stripes, the median one bordered by chestnut brown; a yellowish white stripe on either side of the back separating the two lateral black stripes; under parts white or whitish; tail rufous margined with black.

Measurements.-Total length, 9.60 inches; tail vertebræ, 3.75 inches; hind foot, 1.25 inches.

This is one of the smaller members of the family and is further characterized by the flattened and only slightly bushy tail, the striped back and the chestnut rufous rump; it is also smaller than its nearest ally, T. s. griseus.

It is probable that many records of this species in the state may be referred to the following form and that the two have been often confused. The exact status of these forms is not yet definitely known. In habits and general charasteristics the present form is very like T. s. griseus. A single specimen in the Coe College Museum, collected at Traer, June 23, 1902, and another collected at Iowa City are the only two definite locality records which are available. Reports from different parts of the state indicate that "chipmunks" are becoming less common; and this, no doubt, is due to the clearing of many of the timbered areas for agricultural purposes. Damage from this or the following species has not been reported.

\section{GRAY CHIPMUNK. GRAY STRIPED CHIPMUNK.}

Tamias striatus griseus Mearns.

Tamias striatus griseus Mearns, Bull. Am. Mus. Nat. Hist., III, 231, 1891.

Description.-Very similar to Tamias striatus striatus but grayer and larger; lower back and rump cinnamon brown; back with five black stripes between which the color is distinctly gray; under surface of tail paler and the hairs of the tail tipped with gray.

Measurements.-Total length, 10.25 inches; tail vertebræ, 4.15 inches; hind foot, 1.45 inches.

This form varies somewhat in color and in measurements, those indicated above being the average, and variations of a half inch above or below those given may occur. It may be distinguished from the preceding form by its larger size and by the darker color of the rump. Intermediates are likely to be met with, particularly in northeastern Iowa, but most of the Iowa specimens seem to be referable to T. s. griseus. 
Habits, Distribution, Etc.-The gray chipmunk is more terrestrial in its habits than any of the species of squirrels which have been discussed and it is usually found in rocky, wooded areas grown up in underbrush and about old logs or buildings which are surrounded by growths of bushes and weeds to offer concealment. Sometimes it ascends large trees, but for the most part it contents itself with climbing about logs, rocks, and fences and in this art it is very expert. During the summer it industriously stores up grain, seeds, nuts, etc., for food during the winter. These materials are carried to its home, which is usually an underground burrow among loose rocks or under a decaying log or stump. In addition to these things it subsists to some extent upon young mice, birds, and small snakes.

While the gray chipmunk does not truly hibernate during the winter, it remains quiescent for longer or shorter periods of time during severe weather; when the weather moderates, even though there is snow on the ground, it comes forth and disports itself in its accustomed manner. In many cases, however, on the approach of cold weather it $t$ ters its burrow not to reappear until

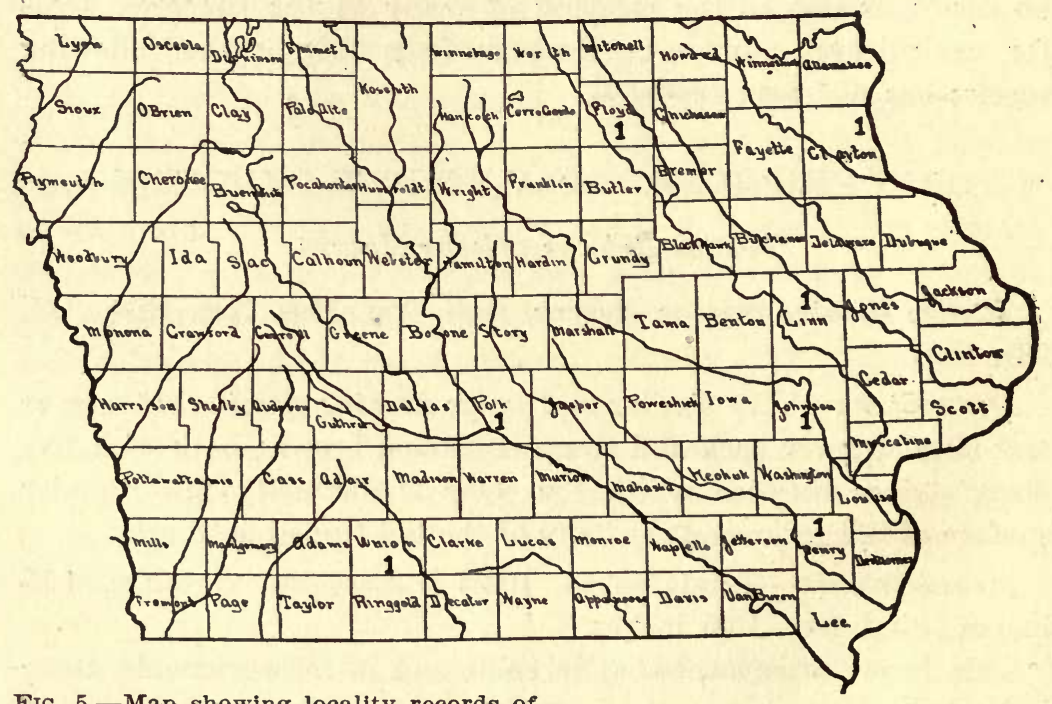

FIG. 5.-Map showing locality records of-

1. Gray Chipmunk (Tamias striatus griseus).

the signs of early spring have tempered the surroundings. These little animals afford interesting diversion for the observer if they are allowed to come about buildings, and the writer has never 
heard of any damage being attributed to them, beyond the carrying away of a few nuts. This chipmunk is somewhat sociable and more or less gregarious; sometimes several pairs apparently occupy the same burrow during the winter. The young are usually four or five in number and are born blind and naked.

When the animal is undisturbed it utters a sort of dull cluck which may be repeated many times, but when it is disturbed a series of rapid shrill chips is often given.

Of the two chipmunks found in the state this seems to be much the more abundant, and the writer has found that in most cases where "chipmunks" are reported, reference is made to this form. It seems to be quite generally distributed over the state and is reported as common or fairly common by nearly all observers. In many localities, however, it is reported that the numbers are rapidly decreasing. At the Iowa Lakeside Laboratory it is quite common in the surrounding woods, and in the summer of 1916 half-grown young were much in evidence during the first half of July. At Iowa City this form as well as the preceding one seems to be present. Other definite locality records for the present species are: McGregor, Cedar Rapids, Des Moines, Wayland, Charles City, Thayer.

THIRTEEN-LINED SPERMOPHILE. STRIPED SPERMO. PHILE. THIRTEEN-LINED GROUND SQUIRREL. STRIPED GROUND SQUIRREL. STRIPED GOPHER.

Citellus tridecemlineatus tridecemlineatus (Mitchill).

Sciurus tridecem-lineatus Mitchill, Med. Repos., N. S., VI, 248, 1821.

Description.-Color above dark brown, varying from chestnut to nearly black; back with seven yellowish white lines which alternate with six rows of rounded yellowish white spots in a background of brown; below pale tawny brown; tail comparatively short and not bushy; middle of tail brown and white bordered by an inner stripe of black, the ends of the hairs forming the fringe buffy white; a pale ring around the eye.

Measurements.-Total length, 10.50 inches; tail vertebræ, 3.75 inches; hind foot, 1.35 inches.

This animal, which possesses an unusually large number of local names, while somewhat squirrel-like in appearance, is the more slender of our two spermophiles and the tail is comparatively short 
and not bushy. The chipmunk (Tamias striatus griseus) is sometimes confused with this species; but the chipmunk inhabits the forests and climbs trees, while the striped spermophile is found on the prairies and does not climb trees. The chipmunk has no spots and is further characterized by a more bushy tail and longer ears. Albino specimens of the striped spermophile are occasionally met with.

The word spermophile by which this and the following species are properly known is derived from the Greek words meaning "seed" and "to love," and refers to the propensity of these animals for eating seeds, which, indeed, form a large part of their diet.

Habits, Distribution, Etc.-This is more particularly a prairie form inhabiting the open fields practically throughout the state, and scattered colonies may be seen in almost any locality not too densely wooded. Often they are found along the edges of timber or groves. The animals are gregarious and diurnal, and during the summer months one often hears their whistle as they scamper through the fields or away from the roadside.

The striped spermophile obtains shelter and protection in burrows which it digs in the ground. These burrows, which are usually made in pastures, along fences and rights of way of railroads, and in other uncultivated places, are about two inches in diameter; they descend abruptly for a short distance and then extend horizontally. Many of the tunnels are short and used simply for safe hiding places when danger approaches. The tunnels leading to the nests where the animals spend the winter and rear their young are often fifteen to twenty feet in length and from one to two feet beneath the surface. The entrance to the burrow is sometimes on the bare ground, sometimes hidden by a tuft of grass.

In the fall the spermophiles become very fat and after a few nights of frost and before the ground freezes they disappear within the burrows not to reappear until the ground thaws in the spring. Competent observers state that these animals hibernate in the true sense of the word for the bodily processes are so feeble that a few degrees below freezing is sufficient to actually cause death. With the thawing out of the ground in the spring the animals issue forth, and the young are usually produced in late May or early June. The number of young in a litter varies from 
seven to ten. They are naked and blind when born and require a longer period of care by the mother than is usual in rodents. In late June and during July when the half-grown young appear above ground the voices of these animals are most frequently heard, the mother and young constantly ealling back and forth; during the breeding season the adults are shy and quiet. In the summer the young begin to dig shallow burrows and before fall leave the mother to shift for themselves.

Adults of this species are at times quite pugnacious and often engage in fierce battles among themselves, scarred faces and ears and lost tips of tails apparently being the most serious results of such encounters. One observer reports having seen a male of this species kill a weasel in a fair fight by biting entirely through the weasel's skull.

The striped spermophile is widely distributed through the central part of North America, and in Iowa is common or abundant in practically every locality visited. It is found generally throughout the state and is much more widely distributed than Franklin's spermophile; in most localities it is more abundant than that species, and its local range is also less restricted.

Food Habits, Economic Importance and Control Mcasures.-As above indicated, the name spermophile means seed lover and scarcely a grain or seed grows where these animals are found that they do not eat. Among the cultivated seeds eaten are wheat, barley, oats, corn, rye, and millet, but their diet is not restricted to these cultivated seeds alone for they are also fond of various cultivated fruits and roots. In addition, acorns, hazelnuts, seeds of pigweed, bindweed, knotweed, pigeon grass, and ragweed make up a goodly share of their food. Nor is their diet confined to the vegetable world; for animal food makes up a part of their diet and they feed particularly on various insects such as grasshoppers, beetles, caterpillars, and ants. "Of the total contents of eighty stomachs examined, more than half consisted of insects. The percentage of animal matter was 52.9 ; of vegetable matter 44.4; and of undetermined matter 2.7. The cheek pouches contained 100 per cent of vegetable matter, being filled exclusively with grain and seeds of various plants." ${ }^{2}$ Since this species is so abundant and widely distributed in the state and because of the nature of its food it has gained an evil reputation among farmers. In addition to destroying the cultivated seeds above

2U. S. Dept. Agr., Bull. No. 4, 43, 1893. 
mentioned observers everywhere report that it pulls up and eats newly planted corn and other seeds. This is especially true if the cultivated field adjoins a pasture or uncultivated area such as is frequently inhabited by these animals. Often the outer five or six rows of newly planted corn are pulled up and destroyed. While the striped spermophile destroys insects of various kinds it does not exercise any qualities of discrimination and beneficial as well as harmful kinds are eaten. On the whole therefore it cannot be said to be of value to the farmer. Vernon Bailey says: (1. e., p. 42.) "Undoubtedly the good which the Striped Spermophiles do by destroying insects, and seeds of noxious weeds is of no small importance but it is doubtful if it is sufficient to offset the damage perpetrated by them in grain fields. In many localities it is impossible to raise a full field of corn without first killing the spermophiles. As soon as the corn is planted they begin to dig up the seed but do most mischief after the corn begins to come up and until it is a week or ten days old, or until all the nutriment is drawn from the grain. They dig down by the side of the stalk and eat the swollen, starchy grain, of which they seem very fond, leaving the stalks to die. As a single spermophile will dig up many hills of corn in a day and continue digging for nearly two weeks, it is not difficult to see that serious damage is done where they are numerous, averaging as they often do four or five to an acre. Large fields of corn are entirely destroyed by them and have to be planted over several times. A great deal of wheat, oats, barley and rye is taken in the same way making it necessary to sow an extra amount of seed. Even this means is not effectual, and frequently fields of sowed grain suffer materially from their attacks. As the small grains begin to fill soon after blossoming the spermophiles eut down the stalks and eat the ovules, and in order to find the best heads they cut down a great deal more than they eat. As the grain becomes hard they carry large stores of it into their burrows to be eaten at leisure, probably when they wake from their winter's sleep. The amount of damage done depends upon the abundance of the animals and is often serious. If a field is small and isolated the spermophiles sometimes collect and destroy almost the whole crop."

The above statement agrees in almost every particular with reports of farmers in practically all parts of the state, so that this animal is to be considered a menace to agriculture. 
These spermophiles do not go their way unmolested, for a number of natural enemies harass and kill them, thus holding the numbers somewhat in check. Among the natural enemies of spermophiles in the state may be mentioned the marsh hawk, Cooper's hawk, red-tailed hawk and its subspecies, Swainson's hawk and red-shouldered hawk; of the owls, the barn owl and the great horned owl render valuable assistance in keeping down the numbers of this destructive rodent. Among the mammals which also render efficient service along this line may be mentioned foxes, skunks, and the badgers, which, however, are comparatively rare in the state. In Dubuque county it is reported that skunks do much towards keeping in check the numbers of striped spermophiles and no doubt this holds true for other localities in the state. Of the weasels the long-tailed species (Putorius longicauda) is of value in controlling the increase among spermophiles for it enters the burrows and kills the occupants without any difficulty. Some of the larger snakes such as the hognosed snake and bull snake also destroy great numbers of spermophiles, particularly the young.

So, even without the aid of man, Nature makes certain provisions for keeping the numbers of these animals within reasonable limits and for preventing a too rapid increase. Thus is obtained a "balance" in nature which Hudson Maxim has expressed as follows: "The harmony of nature depends upon inharmony between the meat-eaters (Carnivora) and the vegetable-eaters (Herbivora). Their interests are, from their very nature antagonistic."

In spite of the efforts on the part of Nature to keep matters adjusted, man has interfered and disarranged the plan by destroying many of his friends which are the enemies of spermophiles. As a direct result of this the number of these animals has increased very markedly in many localities with a resulting increase in the amount of damage. On this account the expedient of offering a bounty has been tried in some counties, in few of which it has been continued for any length of time. The bounty situation is taken up more fully under the discussion on the pocket gopher farther on in this bulletin and so will be but briefly considered here. A bounty, at best, can be but a temporary method of reducing the numbers of these or any animals and is altogether impracticable as a method of exterminating them. 
In Iowa, wherever bounty has been paid on these animals, it has been at the option of the boards of supervisors and there has been no uniformity in the matter of the amounts offered or in the evidence required for payment of bounty. As a result, fraudulent means have been employed in some instances to secure bounty money and a considerable amount of the county funds has often been diverted for such payment without securing adequate returns for the amount expended. Not one of the counties visited during the prosecution of this work pays a bounty upon the striped spermophile, although some counties have paid in past years. As illustrating the point under discussion we may take Lyon county as a typical example. In 1914, $\$ 2132.66$ was paid out for all bounties. During the two months March and April of that year, $\$ 1684.00$ of the above amount was paid out in bounty on the striped spermophile and Franklin's spermophile at five and ten cents each respectively. According to the county auditor the bounty on both these animals has been discontinued, because it caused too great a drain upon the county funds in proportion to the amount of benefit derived.

While spermophiles do render some assistance to the farmer, as has been indicated above, ways and means must be devised for combating them when the numbers become excessive and crops are damaged to a serious extent. However, a wholesale destruction of the animals is not advisable and if serious damage is not done they should be spared for the good which they do. In many localities this damage is very great and would be still greater if some methods of control were not employed. In many places which have been visited various control measures have been used to which the bounty offered upon the animals is supplementary. Among the effective and economical means for destroying these animals may be mentioned fire arms, traps, poisoning, and fumigation.

Under certain conditions where the animals are not too numerous or wary, small areas such as meadows and pastures may be freed from spermophiles by shooting; but they soon become so shy that it is difficult to secure them in this way and more economical and efficient methods must be substituted.

Trapping is slow but has the advantage in being sure, simple and safe and spermophiles are easily taken in this way. For ordinary purposes the No. 0 steel trap with the spring under the pan 
has been found very effective. The trap should be chained to a stake or heavy object and set at the mouth of a burrow; it should be covered lightly with fine earth, and may be baited with almost any kind of grain although the bait is not essential. The guillotine traps of which there are many kinds on the market are also well suited to this purpose since they kill instantly. Rolled oats or almost any kind of grain may be used as bait.

For poisoning, the formula given under the discussion on the prairie $\operatorname{dog}(p .42)$ is very effective against spermophiles. A teaspoonful of the poisoned oats should be placed near each spermophile hole on the hard ground, letting it scatter somewhat as it falls. Early spring, as soon as the animals are out of hibernation and when the vegetation is not far along is the best time to poison the animals.

Another poison formula which has been successfully employed in the West may be added here:

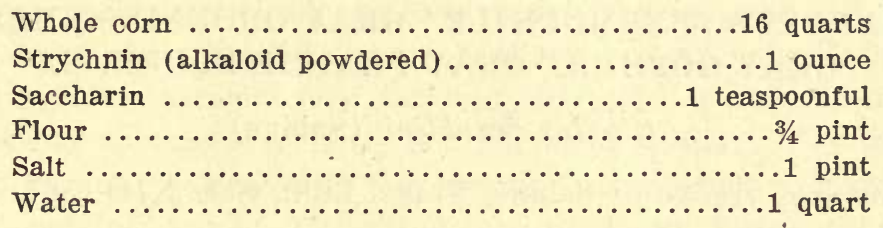

Dissolve the saccharin and strychnin in the amount of water called for, add the flour and salt, mix thoroughly with an eggbeater and heat until the flour begins to thicken, stirring constantly Pour the poison solution over the grain and mix thoroughly, then spread and dry.

Follow the above directions closely, for success in the use of the formula depends upon accuracy in the preparation of the poison solution and upon the complete coating of the grain. A half dozen kernels will suffice for each burrow and experiments have shown that not more than one or two kernels are required to kill an animąl.

Caution.-Do not put the poisoned grain where stock, birds, or children will have access to it.

Fumigation by means of carbon bisulphid is also an effective and cheap method of combating these animals. Carbon bisulphid is a colorless liquid with a peculiarly offensive odor and is a violent poison when taken internally. Its use in fumigation depends upon the fact that it evaporates rapidly, giving off a poisonous vapor which is heavier than air. For this purpose the 
commercial variety is as good as and cheaper than the pure. To use, roll into a ball about the size of a hen's egg a wad of cotton or waste and saturate thoroughly with the liquid. Push this saturated waste as far down the burrow as possible and quickly close the opening with earth to prevent any possible escape of the fumes. The best time for fumigating is just following a rain when the soil is saturated with water and the fumes of the liquid are less likely to escape. With this method the animal is killed within its own burrow and thus ereates no offensive odor upon decaying, while too, there is no risk of its poisoning any other animal even though it be dug up.

Caution.-Carbon bisulphid is an inflammable and highly explosive liquid and should not be handled near a fire or near anyone who is smoking. It also evaporates very rapidly and should be kept tightly corked.

FRANKLIN'S SPERMOPHILE. GRAY GROUND SQUIRREL. GRAY GOPHER. GRAY PRAIRIE SQUIRREL.

Citellus franklini (Sabine).

Arctomys franklinii Sabine, Trans. Linn. Soc. XIII, 587, 1822.

Description.-Color above, except on head and tail, yellowish or grayish brown, the hairs marked with blackish; top and sides of head and neck blackish lightly speckled with white; a buffy ring around the eye; color below buffy white; tail grayish with three blackish lines, the outermost broad and fringed with white.

In the young the brownish or tawny tinge is not so evident and the back has irregular blackish bars.

Measurements.-Total length, 14.75 inches; tail vertebræ, 4.75 inches; hind foot, 1.85 inches.

This form resembles somewhat a small gray squirrel, but may at once be known by the shorter and less bushy tail, the more evident tawny tinge of the upper parts, and the very short ears.

While this animal possesses a very great number of popular names, none are employed consistently throughout its range except perhaps the least known of these, Franklin's spermophilethe only one which is properly applicable to this form and the one which we shall employ in this discussion.

Habits, Distribution, Etc.-Franklin's spermophile is an inhabitant of open prairies and is not found in timbered regions, al- 
though it often lives along the edges of timber and small groves. At Lake Okoboji it is quite common near the sparse woods and groves bordering the water, and has even taken up its abode near the buildings of the Lakeside Laboratory. In most places it is not as common as the striped spermophile although in a few localities it is reported as more common than that species. In most places the two species range together and their habits are also very similar. The note of Franklin's spermophile is the same rapid, shrill trill of the striped spermophile but somewhat heavier. As with the other spermophiles, this form is often seen sitting erect and motionless on its hind feet near the opening to the burrow. When alarmed it usually runs with a low, sneaking gait through the grass, but when very much frightened takes long liaps.

This species also constructs a burrow which is similar to that of the striped spermophile but somewhat deeper; in many cases these burrows are excavated in cultivated fields. The nests to which the burrows lead are constructed of grass and soft plants and are always kept clean and sanitary. In autumn Franklin's spermophiles become very fat and disappear within their burrows not to reappear until the following spring. The time of reappearance varies with the season, but is usually during the first half of April. The young are produced during the latter part of May and by the first of August are half grown.

This species is more migratory in its habits than the striped spermophile; the males live a wandering life during the summer, and indeed pairs or even small companies of individuals frequently migrate from one locality to another; sometimes a pair will migrate from the wintering burrow to a breeding burrow and perhaps winter in still another. This migratory habit may account for the reports received from various places to the effect that "this species was common here last summer, but I have seen only a very few this year."

From various sources it has been learned that not often do this species and the striped spermophiles inhabit the same field; and it seems that the latter, being somewhat more pugnacious, drive the Franklin's spermophiles from any limited territory which they themselves wish to occupy.

Although this form is quite generally distributed throughout the state, in the driftless region of northeastern Iowa it is not commonly met with. It seems, however, to be working its way 
into this region from the north and west, and a few miles west of the hilly section it is fairly common. At Corning it is reported that this species did not appear until 1909; now it is abundant in that locality. In almost every locality visited Franklin's spermophile is found; but its numbers are, in general, less than those of the striped spermophile. Definite locality records are: West Liberty, Iowa City, Ruthven, Gilmore; Des Moines, Mt. Pleasant, Algona, Hampton, Carroll, Muscatine, Osceola, Corning, Eldora, Rockwell City, Lake Okoboji, Rock Rapids, Spencer, and Cherokee.

Food Habits, Economic Importance, Etc.-Most of the food of Franklin's spermophile consists of seeds and varicus cultivated grains. Corn, wheat, oats, rye, and barley are among its favorite foods; and much complaint is heard from farmers in many sections of the state as to the damage done by this spermophile's digging up newly planted grain. Corn, in particular, is attacked in this way, and when the animals are numerous replanting and careful watching are necessary in order to secure a crop. On one farm in Henry county it was found necessary to replant more than forty acres of corn during one season on account of ravages by these animals. Of course the amount of damage done in a locality is in direct proportion to their numbers, and where they are numerous damage may be quite serious. Among the ripe small grains more of the grain is trampled down in attempting to get at the heads than is actually eaten, so that considerable loss occurs in this manner also.

While grains and other vegetable food make up a large share of the entire food of Franklin's spermophile, animal food is also taken. Many insects such as beetles, crickets, grasshoppers, caterpillars, and ants also are eaten and thus perhaps some of the evil which it does is mitigated by its usefulness in destroying these noxious forms.

On the farms damage is also sustained from the animal owing to its inclination to burrow in or along the banks of ditches and under drains filled with brush so that wher heavy rains come these banks are more easily washed away.

Natural enemies of various kinds, among them the hawks and owls mentioned as enemies of the striped spermophile, tend to keep down to a certain extent the numbers of Franklin's spermophile. A good many are caught by house cats also in regions where these spermophiles are abundant, since they seem to have 
a habit of frequenting old buildings and even situations near buildings which are in use; this coupled with the fact that they are perhaps somewhat less active than the striped spermophiles renders them more liable to attack by the felines.

Franklin's spermophiles have long been recognized as enemies of agricultural interests and the expedient of offering bounty has been resorted to in various counties in the hope of either exterminating them or materially reducing their numbers. These sporadic attempts have not met with any degree of success. Although it is apparent that this species is recognized as more destructive in its habits than the striped spermophile, the added incentive to its capture in the way of a larger bounty offered has proved of no avail. In none of the counties visited is a bounty now paid upon these animals; but in several, bounties once in vogue have been discontinued because they did not bring the desired results. In some places inquiries are made by farmers from time to time as to whether a bounty is paid. Certain localities seem still to indicate a sentiment towards paying a bounty but indicate further that it should be uniform throughout the state. The bounty system is considered more fully in the discussion on the pocket gopher.

In general, the same control measures recommended for the striped spermophile are applicable to the Franklin's spermophile when its numbers become excessive in any locality. In addition, these animals as well as the striped spermophiles, may be drowned out by pouring water into their burrows and since this species is less active than the striped spermophile it may be more easily killed with a club when it leaves the burrow following such a deluge.

In Clay county much success in controlling the numbers of Franklin's spermophile has been met with in the use of poisoned corn. A solution of strychnin sulphate, two cunces to two quarts of water, is made, and shelled corn is soaked over night in this. The poisoned corn is then scattered along the edges of fields and in fields infested with this spermophile. While this method has been found effective, it is not especially recommended since the poisoned grain may be eaten by birds and other animals for which it is not intended. Instead of scattering the corn promiscuously it is better to put a few grains at the entrances of the burrows as this lessens the likelihood of other animals feeding upon it. Care should be taken that domestic animals are kept from the poisoned grain. 


\section{BLACK-TAILED PRAIRIE-DOG. PRAIRIE-DOG.}

\section{Cynomys ludovicianus ludovicianus (Ord).}

Arctomys ludoviciana Ord, Guthrie's Geogr., 2d Amer. ed., II, 292, 302, 1815.

Description.-Summer: Above reddish brown, varied with gray and black hairs; upper lip, sides of nose and eye ring buffy white; cheeks and sides of head buffy with blackish hairs; feet buffy; tail above like back, the apical third black or blackish brown above and below; under parts of body from chin to near tail white or buffy white. Winter: Pelage much thicker, longer and softer than in summer; above, grayish cinnamon with numerous intermingled black hairs; tail as in summer; under parts pale-buff or cinnamon, the hairs black at bases.

Measurements.-Total length, 15.57 incbes; tail vertebræ, 3.50 inches; hind foot, 2.57 inches.

Owing to the fact that both summer and winter coats fade and wear, the variations in color are very great. All prairie-dogs but one species have two molts annually; these molts are entire except on the tail where there is but a single yearly renewal; as a result, specimens may be found in all stages of intergradation depending somewhat upon the season.

The prairie-dog is one of the true ground squirrels or spermophiles and the appellation "dog" is not strictly in accordance with science. However, owing to the very general usage of the word in connection with this animal a substitute would perhaps be out of place.

Habits, Distribution, Etc.-Although the prairie-dog appears to have made but little headway in increasing its range in Iowa, and although it is present in only a few restricted localities along our western border, it will bear watching and any further spread of the species should at once be combated. Sometimes it is practically omnivorous, feeding upon grasses, roots, stems, and leaves of green plants. Without doubt it is responsible, in western localities, for great damage to grain and pastures; and in some places practically the entire forage crop would be lost unless preventive measures were taken. Of course in many localities the "towns" occupy waste places and in such instances they do not interfere with man. In their natural habitat, the Great Plains and Rocky Mountain regions of the United States, these animals are gre- 

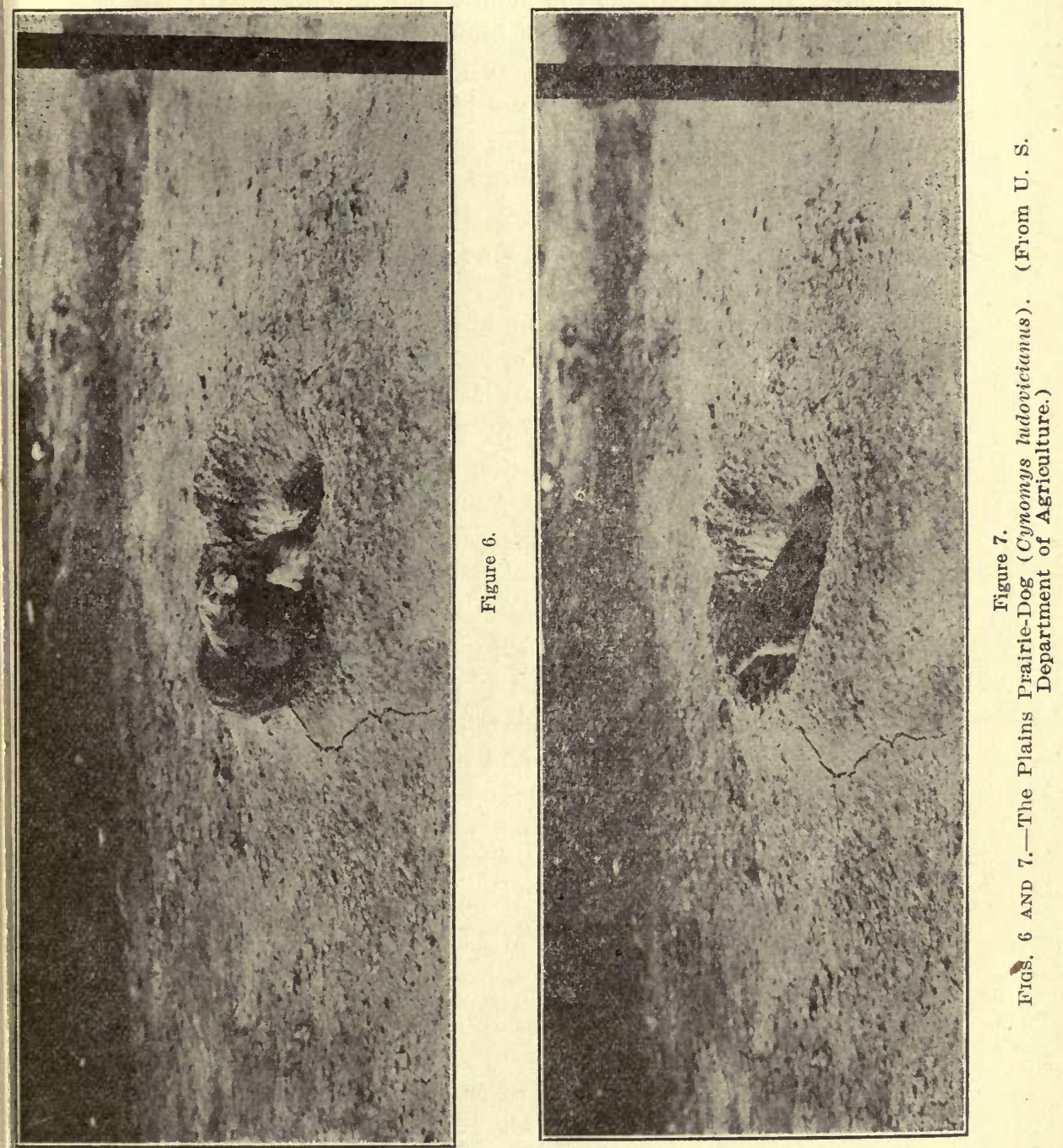
garious, and some of the villages extend for miles while the number of inhabitants is very great.

The burrows in which the animals live vary according to local conditions. In arid regions the mounds are usually small; but in places where the rainfall is great, high mounds are necessary and require the constant care and attention of the animals. Prairiedogs, except at high altitudes, do not hibernate, although they may remain under cover for days during severe winter weather. They may, however, appear above ground on fine days even though the ground is covered with snow. In the extreme north, when deep snow covers the villages for many weeks the animals remain concealed for long periods.

Prairie-dogs are attacked by a number of natural enemies among which are the coyote, badger, eagle, black-footed ferret, and roughlegged hawk. Although many stories have been told concerning the occupancy of a single burrow by prairie-dogs, burrowing owls and rattlesnakes, careful observation shows that while all these animals are often found together, the association is not of advantage to the prairie-dog, for many of its young are sacrificed to the intruders.

Control Measures.-In many localities where the animals are abundant various measures of extermination have been tried, among the best of which is the use of poison-coated grain. A formula similar to the one given below has been employed with excellent results in North Dakota and elsewhere and is equally effective in destroying Franklin's and the thirteen-lined spermophiles.

Formula for poison preparation:

1. Mix thoroughly 1 ounce strychnia sulphate (powdered) and 1 ounce baking soda.

2. Sift this into $3 / 4$ pint thin hot starch paste and stir to a creamy mass. Make the starch paste by dissolving a tablespoonful of dry gloss starch in a little cold water, then add this to $3 / 4$ pint of bolling water. Boil and stir constantly until a thin paste is formed.

3. Add $1 / 4$ pint heavy corn syrup and stir thoroughly.

4. Add $1 / 8$ ounce saccharin (or sugar 1 pint) and stir thoroughly.

5. Pour poison solution over $\mathbf{1 5}$ quarts clean oats and mix thoroughly so that each grain is coated. Prepare 24 to 48 hours before using. 


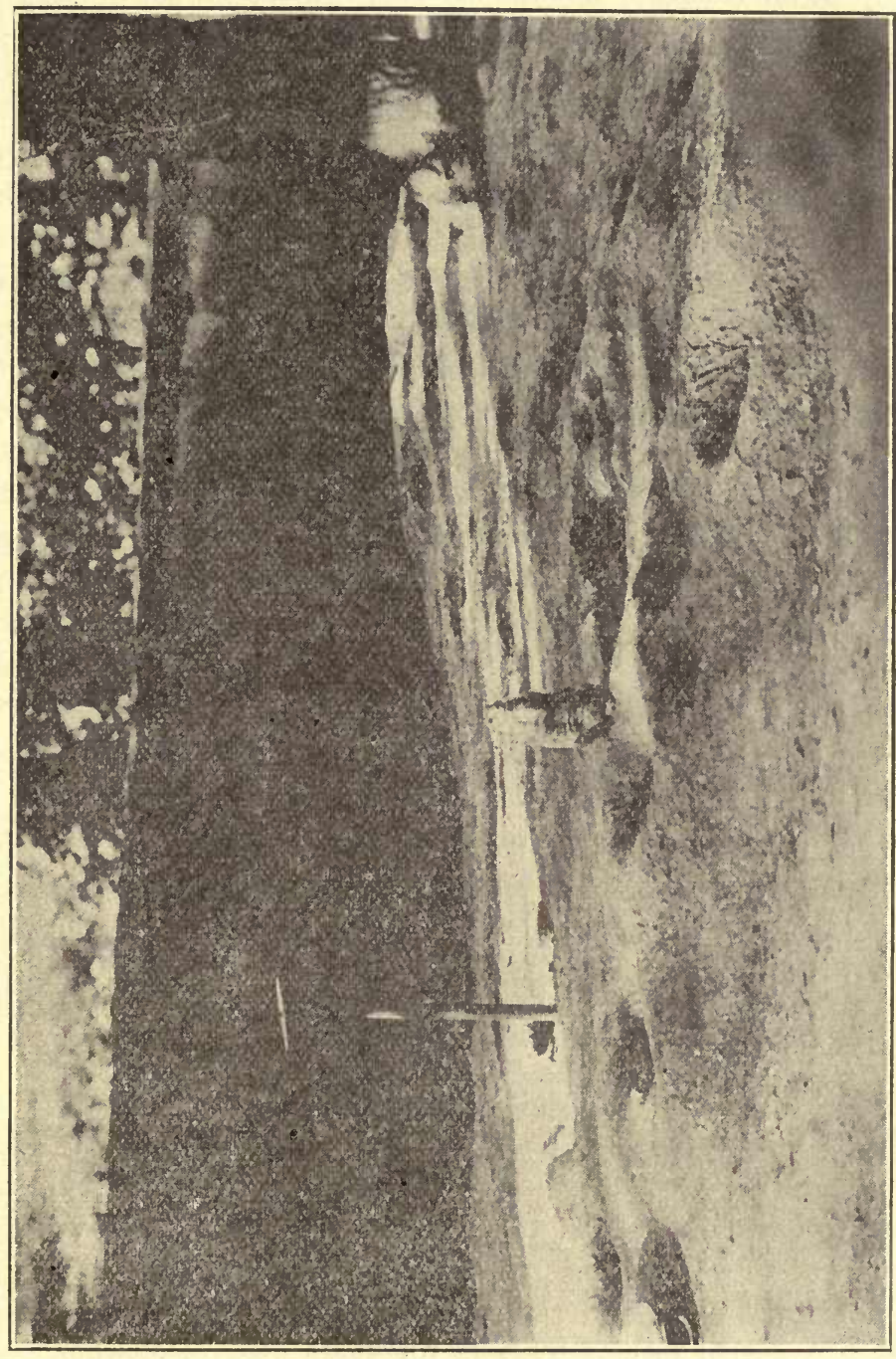

क्ष 
6. Distribute a tablespoonful of poisoned oats on the clean, hard ground before the hole. A quart of grain will be sufficient to treat forty holes. Put out in early morning and take special care that the grain is not put on the loose earth of the mound or into the burrows. Do not put out in rainy weather, and take special precautions that other animals, particularly birds, do not reach it. Foisoning is best done in early spring before the vegetation is well along.

The Prairie-dog in Iowa.-The prairie-dog has been reported from a number of localities in Iowa, but in most cases the records are for introduced individuals or colonies. Introduced colonies are reported to have existed at Burlington, and from Jackson township in Sac county a prairie-dog town of about twenty burrows was reported in 1900 ; but in both cases it is likely that the individuals were escaped pets or their descendants. A specimen reported to have been killed in Palo Alto county a few years ago, was probably an escaped pet since such an animal had been lost some time before the specimen mentioned was killed. At Logan in Harrison county a specimen of this species was killed in a lumber yard in 1916, but it appears likely that this also was an introduced individual. M. P. Somes reports that he has seen "two small colonies of the prairie-dog between the Missouri River and the C. M. \& St. P. R. R. tracks about five miles north of Calliope in Sioux County." Frank C. Pellett says, "Knew of one in Cass county several years ago.",3

At the present time J. A. Moody of Shenandoah has two small colonies of prairie-dogs on his farm, one colony about one hundred and fifty yards from his home, the other about forty rods distant. He writes as follows regarding the animals: "They were not native of this part but a single pair was sent me some 20 years back from Fort Morgan, Colorado. The animals increased rapidly as each mother dog will rear ân average of about six young each year. They are inclined to be very domestic and will not wander away from their little towns unless overerowded. In that case they will seek other parts.... Nothing is allowed to grow within the bounds of their colony but grass; not a weed or a bush is allowed to grow. This is for their own protection. The colony nearest our home contains about thirty, the larger one about a hundred.... If not allowed to become too numerous and colonize on pasture land they will remain there and will not molest the nearby growing crops in any way. For destroying the animals I use

${ }^{3}$ Proc. Ia. Acad. Sci., XVII, 214, 1910. 
earbon disulphide... The holes run down at an angle of about 45 degrees to a depth of nearly or quite seven feet, then they continue their burrows for some four feet further on a level. At the end a spacious room is rounded out large enough for the family that is to occupy the snug, warm place."

The above records seem to indicate that the prairie-dog is not particularly successful in maintaining itself in the state, even if it is introduced; and the Missouri river seems to have served as a fairly effective natural barrier to its eastward dispersal from $\mathrm{Ne}$ braska. It may, however, be in place here to utter a timely word of warning in regard to the introduction of such noxious animals as pets or for exhibition. As has been pointed out before this is a species which may become a pest and a menace to agriculture on account of its fecundity, its adaptability, and its food habits; so it were better not to take any chances of its spreading by introducing it into any locality. If specimens are brought into the state great care should be taken that they be placed in properly constructed eages from which there is no possibility of escape. Such a serious matter should receive due forethought and consideration and care should be exercised that this pest of western states does not obtain a foothold in our own.

SOUTHERN WOODCHUCK. WOODCHUCK. GROUND HOG.

Marmota monax monax (Linnæus).

[Mus] monax Linnæus, Syst. Nat., X ed. I, 60, 1758.

Description.-Color above grayish brown, the hairs of the back reddish brown with gray tips and black bases; cheeks gray, the mouth margined with whitish; nose and chin gray; tail dark brown, the hairs tipped with gray; color below brownish chestnut; feet brownish or blackish; throat grayish.

Measurements.-Total length, 23.25 inches; tail vertebræ, 5.50 inches; hind foot, 3.50 inches.

This species is somewhat variable both as to size and coloration; in length it varies from twenty to twenty-five inches, and in coloration from pure white to black; although, of course, specimens colored some shade of gray are much more common than are specimens of other colors.

Habits, Distribution, Etc.-The woodehuck is a common rodent throughout the eastern half of the state, but is seldom met with in the extreme western counties. It is the largest common rodent 
now existing in the state and in point of size is exceeded only by the porcupine and the beaver, neither of which now probably occurs within our borders. Frank C. Pellett has a specimen taken at Atlantic in 1916, and says that he has seen but one other in Cass county during the last thirty years although he has heard of two more specimens that have been taken in that county. In North American Fauna No. 37, 1915, a specimen of this form is recorded from Wall Lake. At Emmetsburg a specimen was taken a few years ago along the west branch of the Des Moines river. Along the Chicago, Milwaukee \& St. Paul Railroad tracks between Fostoria and Milford the writer found two burrows of this species. The above data indicate that while the woodchuck is found ocea. sionally in the western part of the state its numbers there are much less than in our eastern more wooded and rougher counties.

The woodchuck, or ground hog as it is commonly called, is frequently found in open prairie fields, where it digs burrows in the ground. In hilly regions it often constructs its burrows in the side of a ledge of earth or fill. The animal is seldom found in wooded areas, but often digs its burrows along the edges of woods or groves. The burrows vary considerably in length and form. The shorter burrows are in most cases not more than ten feet in length, while few of the longest are longer than fifty feet; usually they extend parallel to the surface of the earth and four or five feet below it, and each burrow ordinarily has at least two points of entrance.

The following sketch shows the plan of a woodchuck burrow examined by Charles B. Cory at Lake Geneva, Wisconsin, and is taken from his book, "The Mammals of Illinois and Wisconsin," page 153.4 Usually only a single pair of the animals inhabits a burrow. The young are produced in the latter part of April, and there are usually from four to six in a litter. They are very small and blind when born and do not emerge from the burrow until permanent warm weather occurs.

Woodchucks do not store up food for winter use, for they hibernate during the cold season. A popular superstition is abroad to the effect that the woodchuck emerges from its burrow on the second day of February and looks about. If he sees his shadow cold weather, it is thought, will continue for a period of at least six weeks and he will return into his burrow to continue his sleep for that length of time; if, however, he fails to see his shadow,

${ }^{4}$ Cory, Charles B., Pub. Field Mus. Nat. Hist. Zool. Series, Vol. XI, 1912. 
spring will open early and the cold weather will be of short duration. Of course there is no truth attached to this superstition and the way in which it arose is merely a matter of conjecture.

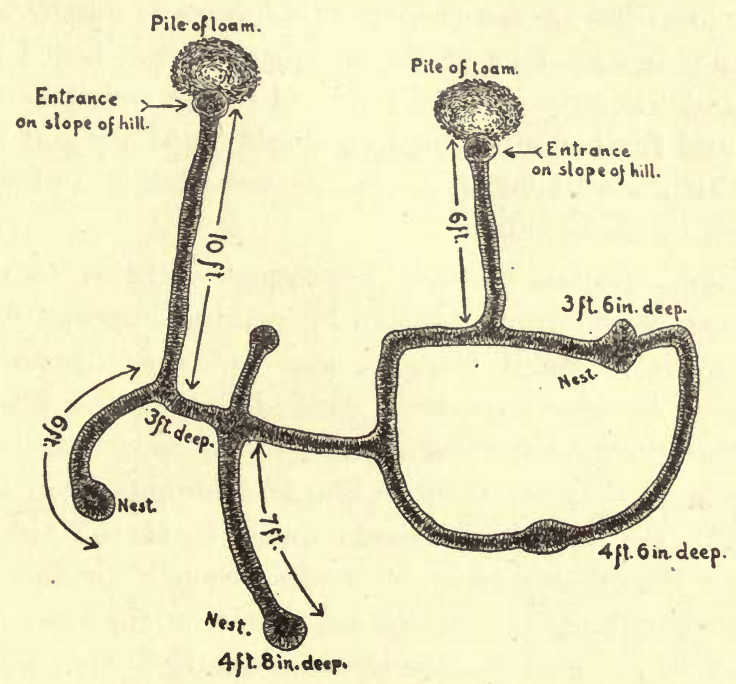

Fig. 9.-Plan of a Wloodchuck burrow. (From Field Museum of Natural History.)

The woodchuck is more particularly a ground inhabiting species and does not habitually climb trees. It is able, nevertheless, to climb with a fair degree of skill. While walking along the road near Waukon, in northeastern Iowa, the writer once disturbed an adult of this species which had been feeding on the vegetation in a nearby pasture. The animal galloped rapidly through the grass to a small white oak tree a few yards distant and ran up the trunk about ten feet without apparent exertion. The animal was soon dispatched with a club, and on opening the stomach it was found to be entirely filled with blades of green grass and the leaves and stems of weeds.

Food Habits, Economic Importance and Control Measures.Woodchucks are, for the most part, vegetarians in their food habits, the favorite food being grasses and clover; but if present in localities where truck crops are raised, they will eat pumpkins, beans, cabbage, melons, young corn, etc. They are very fond of corn when it is in the milk, and often destroy much more than they eat by breaking down the stalks and leaving the ears half-devoured. The animals feed regularly morning and evening and often during 
the day and on clear, moonlight nights. Usually they are quite shy and when disturbed move with a low, loping gait. If cornered they are able to put up a very presentable fight.

In many localities farmers report this speeies as destroying young ehickens and ducks. One of the members of the board of supervisors in Dallas county in 1914 reported to the writer several such instances, and further said that in a single night sixty of his young chickens which were kept in a brooder were killed and some were partly eaten by these animals.

In Dubuque, Dallas, Clarke, and other counties visited, these animals cause considerable damage by making burrows behind the abutment walls of small bridges; and in many instances entire approaches to bridges have been washed out during heavy rains, on account of their having been undermined by woodchucks. The animals seem to be most troublesome and abundant on low roads near timber; on the higher roads away from the timber their harmfulness is not so great. Of course cement bridges and culverts offer something in the way of protection in such cases, but even with such precautions considerable damage often follows.

In places it is reported that these animals burrow under shocks of grain, not only destroying the grain but in addition leaving large holes in the earth which may be the beginnings of washouts or in which farm stock may step with possible serious injury.

Again, many complaints have keen made that the "dead earth" thrown out by the animals in constructing their burrows covers up the vegetation and underlying productive soil, and that the earth thus thrown out is not productive until it has been fertilized and cultivated for a time.

The flesh of the wood.chuck is said to be very palatable and there is no good reason why it should not be considered fit for food. The habits of the animals are cleanly, the burrows and nests are clean, and there is nothing in their food habits to render them objectionable. The fur is not much used, since it is harsh and coarse; but the skin when tanned makes a good, pliable, and wearresisting leather.

In consideration of its damage to agricultural interests and to the successful upkeep of good roads, which have now come to be a necessity, the woodchuck must be reckoned with; and here as in other instances attempts have been made in some counties to reduce the numbers by offering bounties. The following table 
will show in condensed form the bounty situation in the counties in which inquiry has been made.

\begin{tabular}{|c|c|c|c|c|}
\hline CoUnty & $\begin{array}{l}\text { RATE } \\
\text { (CENTS) }\end{array}$ & DATE & $\begin{array}{l}\text { AM'T PAID on } \\
\text { WOODCHUCKS }\end{array}$ & REMARKS \\
\hline Allamakee & 10 & 1914 & (June) $\$ 112.10$ & $\begin{array}{l}1909 \text { offered } 15 \mathrm{c} \text { each; } 1912 \$ 1.00 \\
\text { a dozen }\end{array}$ \\
\hline & & 1915 & & Discontinued \\
\hline Buchanan & 25 & 1913 & 250.00 & \\
\hline & & 1915 & $\cdots \ddot{3}$ & $\begin{array}{l}\text { Discontinued } \\
\text { Began paying bounty in } 1911\end{array}$ \\
\hline Clay & 25 & $\begin{array}{l}1913 \\
1915\end{array}$ & $\begin{array}{l}2.50 \\
8.35\end{array}$ & \\
\hline Clayton & 25 & $\begin{array}{l}1913 \\
1915\end{array}$ & $\begin{array}{l}1,314.00 \\
1,665.15\end{array}$ & \\
\hline Dallas & 15 & $\begin{array}{l}1913 \\
1915\end{array}$ & $\begin{array}{r}53.60 \\
\ldots \ldots\end{array}$ & Discontinued \\
\hline Davis & 25 & $\begin{array}{l}1913 \\
1915\end{array}$ & $\begin{array}{r}1.50 \\
146.75\end{array}$ & \\
\hline Delaware & 20 & $\begin{array}{l}1913 \\
1915\end{array}$ & $\begin{array}{l}714.20 \\
763.45\end{array}$ & \\
\hline Fayette & 20 & $\begin{array}{l}1910 \\
1915\end{array}$ & $\begin{array}{r}2,064.80 \\
\ldots \ldots\end{array}$ & Paid only in 1910 and 1911 \\
\hline Henry & 20 & $\begin{array}{l}1913 \\
1915\end{array}$ & $\cdots \cdots$ & $\begin{array}{l}\text { Withdrew in } 1912 \\
\text { No bounty }\end{array}$ \\
\hline Union & 15 & $\begin{array}{l}1913 \\
1915\end{array}$ & $\begin{array}{r}22.95 \\
\ldots \ldots\end{array}$ & $\begin{array}{l}\text { Bounty in } 1913 \text { and } 1914 \text { only } \\
\text { No bounty }\end{array}$ \\
\hline Wapello & 25 & $\begin{array}{l}1913 \\
1915\end{array}$ & $\begin{array}{r}6.50 \\
10.50\end{array}$ & \\
\hline Winnesl & 10 & $\begin{array}{l}1913 \\
1915\end{array}$ & $\begin{array}{r}2,786.00 \\
\ldots \ldots\end{array}$ & $\begin{array}{l}\text { Total bounty on gophers, wolves, } \\
\text { foxes and woodchucks }\end{array}$ \\
\hline
\end{tabular}

Of the sixty-two counties visited during the preparation of this paper but five are now paying a bounty on this animal, althcugh some others have paid a bounty in times past. The most common answer to the question as to why the bounty on woodchucks was discontinued is that it has been too great a drain upon the county funds in proportion to the results obtained. In looking over the table it will be seen that no uniformity of bounty prevails, and that the rate differs from ten cents to twenty-five cents. In some cases the rates in adjacent counties present a considerable difference and animals killed in the county offering a small bounty are often taken to the county in which a larger bounty is paid. It would seem that the bounty in order to be at all effective and fair to everyone concerned should be uniform in all parts of the state. However, the bounty system is not here advocated as an effective method of dealing with the woodchuck situation. In localities where the animals are plentiful and a cause of considerable damage, trapping may be resorted to with excellent results. Woodchucks are easily caught in steel traps and if every farmer 
whose land is infested with these animals would see to it that the numbers are reduced and held in check the situation could be much improved without the expenditure of county funds. The animals can also be shot without difficulty, the principal prerequisite on the part of the hunter being a fair degree of "watchful waiting."

\section{BEAVERS.}

\section{Family CASTORIDE.}

This family is made up of but a single genus, represente: in North America by one species, of which there are five recognized geographical races.

Beavers are the largest of the North American rodents, varying from thirty to fifty pounds in weight, and excepting the capybara of South America, are the largest of existing rodents. The animals are semi-aquatic and the arms and hands are small and adapted for burrowing as well as for holding substances between them. Beavers were and still are in localities where they are sufficiently plentiful, hunted and trapped for their skins which are of great commercial value. In addition, the anal glands of the animal contain an oily, yellowish, sticky, and strongly-scented fluid called castoreum which is used by trappers as a bait; it is also used in the manufacture of perfumes, and is furthermore asserted to have medicinal properties.

The beaver, as a type, is one of the oldest living mammals, and has been contemporaneous with many now extinct species. His prolificacy, semi-aquatic habits, rugged strength, and food habits have fitted him for successful maintenance in his struggle for existence. However, the competition with avaricious man has been too great, and in many places where he was formerly abundant the beaver is now entirely extinct. In both the United States and Canada governmental protection has in recent years, been given this animal, and its numbers are now somewhat on the increase.

\section{BEAVER. CANADIAN BEAVER.}

\section{Castor canadensis canadensis Kuhl.}

Castor canadensis Kuhl, Beitr. z. Zool., 64, 1820.

Description.-General color brown; hairs of upper part dark brown at base and tipped with chestnut; top and sides of head and neck, rump and thighs chestnut; under parts paler than upper 
parts ; tail flat, scaled, paddle-shaped, black in color; claw on second toc of hind foot divided.

The fine or true fur varies in length from one-half to three-fourths inch while the coarse bristle-like hairs are from one and threefourths to two and one-half inches in length, and are dense enough to entirely or almost entirely conceal the fur proper.

Measurements.-Total length, 42.00 inches; tail vertebræ, 16.25 inches; hind foot, 6.75 inches. The bare scaly portion of the tail is about 9.00 inches long, by 4.50 inches wide, and 1.50 inches through the thickest part.

The beaver is somewhat variable as to both size and coloration, reddish brown, however, being the prevailing color; adults weigh from thirty to sixty pounds though the latter weight is attained only in rare instances.

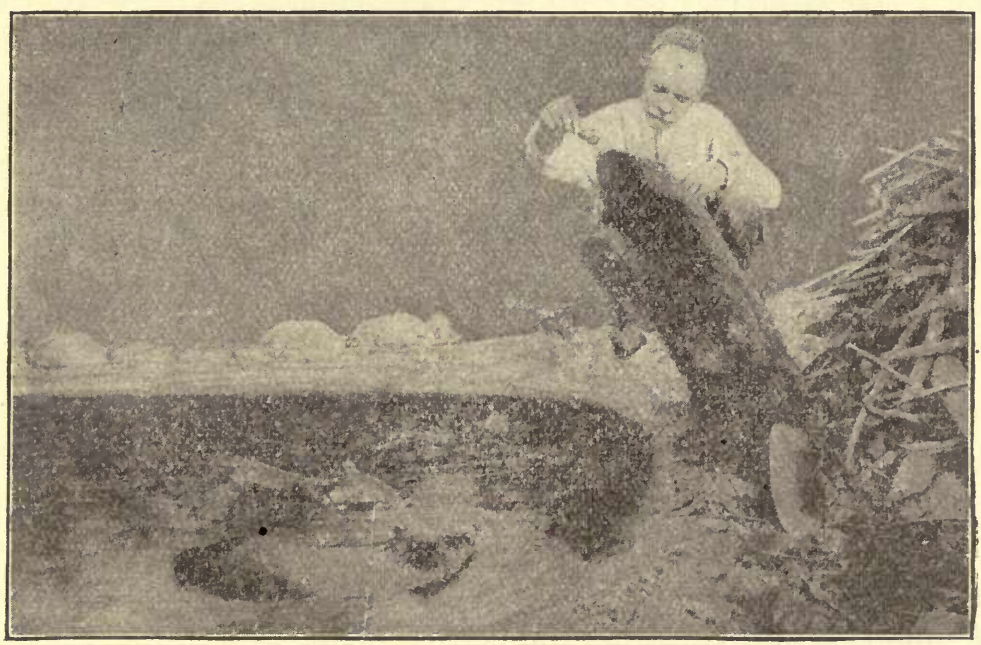

FIG. 10.-Pet Beavers. (From U. S. Department of Agriculture.)

Although in early days beavers were very common in almost all parts of the state, they have been entirely exterminated, the last individuals apparently having been killed in the early nineties. John A. Spurrell of Wall Lake, informs the writer that the last beavers trapped on the Boyer river in Sac county were taken in 1886. M. P. Somes reports that a beaver was killed on Lizard creek, about five miles northwest of Fort Dodge by J. T. Somes about 1887. "A family of beavers is reported by Sirrine as having worked on 
Big Creek, North Tama county, for eight years past, but not a trace of them could be found last fall." 5

Doubtless many other records of the occurrence of this rodent in different parts of the state could be collected; but they would serve no useful purpose so far as the object of this paper is concerned, and those above given will suffice.

\section{RATS AND MICE.}

\section{Family MURIDE.}

The Muridæ is the largest family of rodents and, indeed, of the whole class of mammals, as it numbers over five hundred forms. The family is cosmopolitan in distribution, and some forms such as the brown rat are met with throughout the world, having been carried from place to place in shipping. Every country, including North America, has its own peculiar species. Both terrestrial and aquatic forms are found in the family. Various localities and habitats are chosen according to the mode of life; and swamps, lakes, rivers, prairies, cultivated lands, and woods all have their representatives. In size the members of the family vary from the small harvest mice to the muskrat, the largest representative of the family.

\section{HOUSE MOUSE.}

\section{Mus musculus Linnæus.}

[Mus] musculus Linnæus, Syst. Nat., X ed., I, 62, 1758.

Description.-Color above dark brown grading to lighter brown on sides of body; color below grayish brown, but without distinct line of demarcation between color of this part and that of sides; tail dusky, scantily haired and longer than body; feet grayish brown.

Measurements.-Total length, 6.75 inches; tail vertebræ, 3.15 inches; hind foot, .75 inch.

This form may be distinguished from our other small mice by the grayish brown under parts, the size, the length of tail, and the fact that the molars or grinding teeth have the tubercles on the crowns arranged in three longitudinal rows.

Habits, Distribution, Etc.-The house mouse is a species introduced into this country from Europe, arriving soon after the first American settlements were established. It now inhabits all the

'Nutting, C. C., Proc. Ia. Acad. Sci., I, pt. III, 40, 1892. 
settled parts of North and South America and cecasionally is found even in unsettled districts. It usually reaches a new settlement sooner than the rat, but on account of its small size it does not do so much damage as that species. However, its presence is just as objectionable, and it has the adventage over its larger relatives in being able to crawl through very small holes.

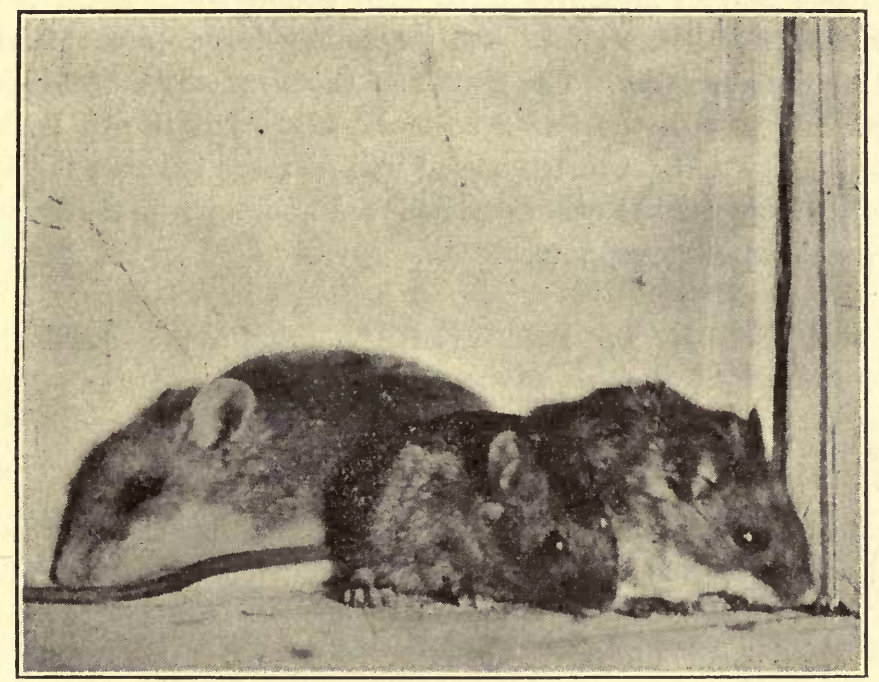

FIG. 11.- Northern White-footed Mouse (left). House Mouse (center). Prairie White-footed Mouse (right). Photo from life by Frank C. Pellett.

The house mouse is extremely r rolific, several litters of from four to ninc each being born in a year. The usual number in a litter is five or six and the young rexch maturity in about three months.

The nests are usually construeted in buildings or cellars and are made from various materials that have been chewed into bits. Paper, clothing, and articles of leather in many eases form the basis f these nests. Often, too, the animals nest out of doors in gardens and fields, and numerous specimens eaught in such places have been sent in to the writer from time to time.

House mice are practically omnivorous in their dict; they feed upon all kinds of animal and vegetable matter, and pollute much that is not eaten. Serious fires are caused when the animals gnaw matches, and floors, furniture, clothing, books, and other stored articles are damaged by their teeth. In addition, these mice are important carriers of bubonic plague and other diseases of human 
beings. During the summer months serious losses to grain in the shock and stack are sustained by their depredations.

When present in any numbers this mouse destroys considerable amounts of food and stores, yet all efforts to exterminate it in the United States have proved futile. Indeed its numbers seem in no way to be diminished.

Various control measures have been employed in keeping down the numbers of house mice, such methods being applicable, in general, for the house rat. The details of these measures are discussed in connection with the latter animal. Suffice it to say here that precautionary and concerted action will do more towards the lessening of damage than is generally believed and such measures should receive widespread support.

\section{HOUSE RAT. BROWN RAT. NORWAY RAT.}

\section{Rattus norvegicus (Erxleben).}

[Mus] norvegicus Erxleben, Syst. Regni Anim., I, 381, 1777.

Description.-General color above grayish brown, darkest on middle of back, the over hairs of the upper parts tipped with black; sides grayer; color below pale grayish brown; hair coarse; tail not longer than head and body, usually less; tail scaly and sparsely haired, above dusky, beneath paler.

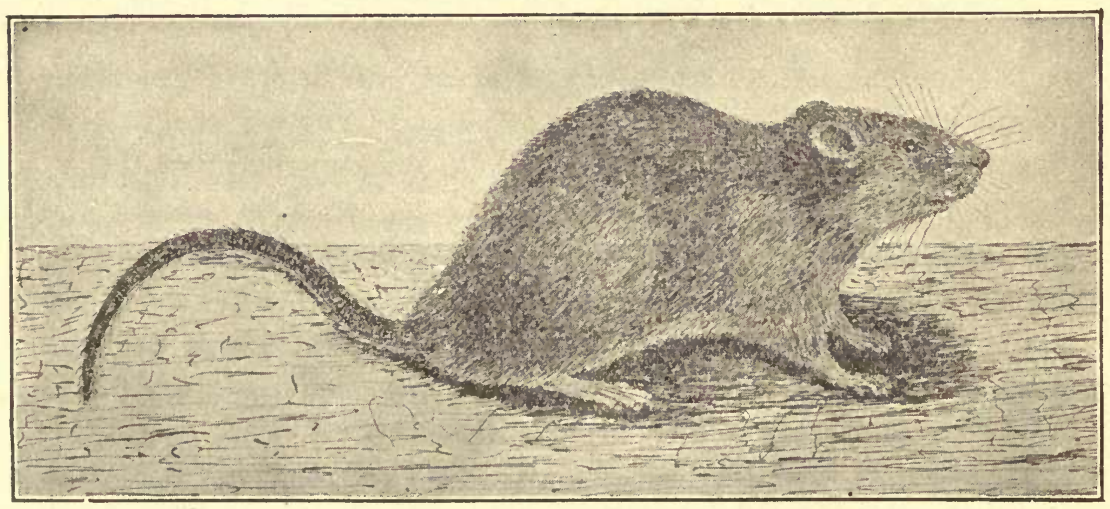

FIG. 12.-The Brown Rat. (From U. S. Department of Agriculture, Bureau of Biological Survey.)

Measurements.-Total length, 16.50 inches; tail vertebræ, 7.10 inches; hind foot, 1.75 inches. 
Rats must be classed as one of the most successful of all groups of animals, and this success is due, in large measure, to their ability to adapt themselves readily to their surroundings. Not only do they exist under seemingly adverse conditions, but they breed and multiply.

This is the common rat found about barns and houses in the country and about warehouses, markets, and wharves in cities. It is supposed to be of Asiatic origin, but its status in this respect has not been definitely determined. It is known that the species reached England from the east.about 1729, having probably migrated thence from northern Asia, and it was first reported in Paris in 1750. It was introduced into the United States, probably from England, about 1775, where, in spite of many attempts at control and extermination, it has increased in distribution as well as in numbers. J. A. Spurrell of Wall Lake, Sac county, writes as follows in regard to the first occurrence of this species in that county: "The first gray or barn rat came from New York in the spring of 1858 in a box of goods. It escaped and was trapped the following fall. Barn rats were next reported in 1868."

Since the brown rat is usually transported in ships, it often becomes first established in a new locality at seacoast towns and from thence works its way inland. Audubon and Bachman report the brown rat as not having reached the Pacific Coast in 1851, but Baird, in 1857 says, "At the present time, however, it is very abundant there [on the Pacific Coast] as far north as the Columbia River."'6 Other writers have thought that this rat appeared in certain California cities even before 1851. At any rate, within a period of approximately eighty years, this pest became pretty generally distributed over almost the entire United States.

Habits, Distribution, Etc.-The brown rat is one of the most abundant rodents in the state. It usually breeds more rapidly than it is destroyed; and such places as stables, warehouses, creameries, sewers, and markets where its food is abundant are often swarming with the pests. Refrigerating plants, cars, and ships also harbor them; and cases have been reported of vessels carrying refrigerating plants which had not been subject to fumigation for a long time, in which the animals had grown an extraordinary coat of fur, which served as a protection against the extreme cold.

'Pac. R. R. Reports, VI, General Report, 439, 1857. 
Without doubt the rate of increase among rats is more rapid in temperate climates, extremes of heat and cold retarding multiplication by decreasing the number of litters and the number of young in each litter. A plentiful supply of stored grain or other nutritious food is also conducive to rapid multiplication and maturity. While young may be found throughout the year, early spring and summer are the periods of greatest reproductive activity. Briefly summarized, the breeding habits of the brown rat as stated by Lantz are as follows: "The animals breed from three to five times a year, each time bringing forth from 6 to 19 young. After a gestation period of twenty-one days the females give birth to their young in nests built in underground burrows or under floors, stacks, lumber, wood piles, or other shelter. The young are blind and naked when born, but grow rapidly, and young females are capable of breeding when less than three months old." 7 In central United States observations show that this rat breeds from six to ten times in a year and produces in each litter an average of ten young.

Inland, where living conditions change with the season, movement of rats from houses, barns, and outbuildings to the fields occurs in spring when the green vegetation lures them forth. Upon the approach of autumn they again seek the shelter of buildings and an abundant food supply in the way of stored grains. While these seasonal migrations are commonly observed, more general movements sometimes occur in which great numbers of rats invade, in a body, new territory, taking up their abode and eausing heavy damage. It is probable that these extensive movements are brought about by overcrowding and the consequent reduction in the food supply.

The brown rat is more pugnacious than the black rat, and in places where the latter formerly held sway it has been driven out by its more formidable relative. Rats seldom attack human beings, except perhaps in self defense; and contrary to a popular opinion the bite is not poisonous, though it may be dangerous owing to the likelihood of infection setting in.

The sight of rats is not keen in daytime, as is indicated by the fact that they move about slowly and with hesitation. However, the whiskers serve as feelers and in them the sense of touch seems to be particularly well developed. It is a common observation that

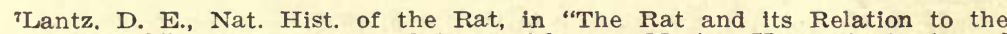
Public Health": Treas. Dept., Pub. Health and Marine Hospital Service of U. S., 1910 . 
rats in attempting to escape an enemy will run along a wall or the side of a room with much greater certainty than in the open.

Food Habits, Economic Importance, and Control Measures.Rats are practically omnivorous in diet, and it is in part due to this fact that they are able to maintain themselves under seemingly adverse circumstances. The following are some of the principal articles of diet: grain and seeds of practically every variety with the food products made from them; fruits and garden erops; bulbs, roots, stems, leaves, and flowers of herbaceous plants ; bark of trees ; eggs, milk, and butter; young chickens, ducks, and other poultry; fresh and decaying meat; mice, rats, fish, frogs, and mollusks. Water is taken in considerable amounts.

The usual feeding time of rats is after sunset, especially if there is more or less disturbance in the vicinity during the daytime. In situations where they are not often disturbed they will feed in daylight. Cellars of houses and the basements of granaries and cribs are the places often chosen for homes; and from the burrows which they usually construct in these places the rats make excursions through the buildings at night in search of food. If food becomes extremely scarce the stronger animals sometimes kill and eat their weaker brethren.

It is estimated that rats cause an annual loss of $\$ 200,000,000$ in the United States alone. Not only the amount of food actually eaten but also that which is polluted and rendered unfit for use must be taken into consideration; so that the material losses thus sustained form sufficient argument for the destruction of the pests. The useful work that is done by rats as scavengers is very slight when compared with their detrimental qualities, and there is adequate reason for saying that the animals should be exterminated if possible.

In addition to the food that is eaten and destroyed by rats and mice considerable damage is done in other ways. Stores and warehouses are invaded and silks, earpets, furniture, furs, leather goods and many other articles are damaged. More than one serious fire can be attributed to rats, because of their gnawing matches or the insulation of electric wires in buildings. Houses are in some cases flooded because the animals have gnawed through lead pipes and occasionally leaks in lead gas-pipes are to be accounted for from the same source. 
The foundations of floors and buildings are in some instances undermined by rats, thus causing the structures to sag or to fall. Unsightly holes in uncemented cellar floors and walls usually indicate the presence of these pests. The corners of doors and of boxes containing stored materials are eaten away; and even artificial ponds and embankments may be ruined by the numerous burrows of the animals.

Rats are also objectionable from an hygienic point of view and are known or suspected to be the transmitters of several diseases.

It is believed that rats are responsible for the presence of human plague in a community, and also that they frequently carry the disease from one locality to another. Rat leprosy is not an uncommon disease among these animals and is of interest because of its similarity to that disease in man. In March, 1917,'T. T. Job of the Department of Animal Biology of the State University came upon a specimen bearing this disease. The rat was collected in one of Iowa City's livery stables.

A number of species of internal parasites are harbored by rats and mice, and some of these parasites bear a close relation to certain diseases of man. The disease known as trichinosis, due to the presence in the body of minute parasitic worms called trichinæ or flesh-worms, is most frequently carried by rats and mice and probably will never be entirely eradicated from man until these rodents themselves have been exterminated. For this reason rats that have been killed or trapped should never be fed to swine, but the bodies should be buried or burned.

Natural Enemies.-To the all too widespread desire for the killing off of birds and other animals which habitually prey on destructive rodents, rats and mice included, the great increase in the number of such pests is largely due. "The value of carnivorous mammals and the larger birds of prey in destroying rats and mice should be more fully recognized, especially by the farmer and game preserver. Rats actually destroy more poultry and game, both eggs and young chicks, than all the birds and wild mammals combined; yet some of their enemies among our most useful birds of prey and carnivorous mammals are persecuted almost to the point of extinction. An enlightened public sentiment should cause the repeal of all bounties on these animals and afford protection to the majority of them." "Greater care should be exercised in discriminating

${ }^{8}$ Lantz, D. E.. House Rats and Mice: U. S. Dept. Agr., Bur. Biol. Surv. Farmers' Buil. 896, 20, 1917. 
between the actually harmful and the harmless birds of prey and predaceous mammals. Too often the farmer is inclined to think that because one hawk, or owl, or skunk destroyed a fowl for him, all hawks, owls, and skunks should be killed since all are harmful. As has before been indicated in this bulletin hasty conclusions should not be drawn; and if the indiscriminate hunter of these animals will take the trouble to investigate he will find that with exceedingly few exceptions all are worthy of his protection, and pay, many times over, for an occasional fowl. The fact that an individual may have the perverted habit of destroying poultry ought not to be taken as sufficient evidence for condemning the species as a whole.

Most of the larger hawks and owls destroy considerable numbers of rats. Hawks feed during the day time and in open fields where rats often go for food; in mornings and afternoons during summer these alert birds of prey find and destroy the rodents. The redtailed hawk, broad-winged hawk, red-shouldered hawk, rough-legged hawk, and the marsh hawk are particularly effective in this work. Owls hunt largely in the evening and at night when mice and rats are abroad about buildings. The barn owl is a most efficient destroyer of rats and mice as well as one of the most wantonly persecuted of this group of predaceous birds on account of its large size and peculiar appearance. It often makes its home about farm buildings, and in such surroundings enjoys ample opportunity for securing rats and mice. Needless to say it is one of the most useful birds on the farm and deserves better treatment than it usually receives. The screech owl, great horned owl, barred owl, long-eared owl, and short-eared owl all destroy rats and mice taken either from the fields or about buildings. While the great horned owl, also occasionally takes a fowl or game bird, the good which it does in destroying rodent pests far outweighs the comparatively small amount of actual damage done.

Of the predaceous mammals, skunks are most efficient as ratters and quickly destroy or drive away rats and mice from the premises. These animals usually hunt at night, and if poultry is properly housed it is safe from them. If skunks are not disturbed they will remain in the vicinity of farm buildings as long as mice and rats may be secured for food. Weasels and minks also destroy many rats and mice, but are prone to attack poultry that is not properly protected from them and sometimes kill apparently merely for the love of killing. 
Domestic dogs, of the terrier variety, with a very little training usually make good ratters and are of value in destroying these rodents about farm buildings, warehouses, etc.

Domestic eats are usually so well fed that they will not make an effort to destroy rats, and, moreover, not many cats will attack a full grown rat. Some cats that will not attack rats will destroy mice; but the half-wild eats that roam the fields at large are usually such inveterate destroyers of young birds and poultry as to counteract their efficiency as mousers.

Tame ferrets are sometimes employed in catching rats, but the services of a well-trained dog are needed in addition, the rats being driven out by the ferret and then killed by the dog. Unmuzzled ferrets sent into the rat burrows are likely to remain quiet after sucking the blood of the rat or to escape through some unlookedfor opening and be lost. Ferrets, too, are delicate creatures and need more or less attention; so that this method of ratting is scarcely likely to produce good results unless the owner of ferrets is experienced in handling these animals.

Precautionary Measures.-Since house rats and mice are much alike in food habits and in the situations chosen for nesting and rearing their young the following precautionary and control measures are applicable, in general, for either pest. In the control of rats and mice, as with the control of other rodent pests, precautionary and preventive measures are more easily effected than are remedial measures after the pests have once gained access to and begun to breed in places offering abundant food and safe retreats.

The use of cement in the construction of modern buildings presents many advantages in the way of eliminating favorable hiding places for rats and mice. Care should be taken that basements and cellar windows left open for ventilation are properly screened and that outer doors are not left open. The lower edges of outer doors to such places as markets and warehouses should be faced with metal plates through which the animals cannot gnaw. Openings in walls, around steam, gas, or water pipes should be closed with concrete. Rat holes can also be closed permanently in this manner. Sometimes bits of glass or crockery are added to the cement to be used for this purpose. Concrete walls, footings, and floors in basements are all effective in keeping these pests from buildings.

Wooden floors, sidewalks, and porches built close to the ground offer safe hiding places for rats and should be replaced by others 
of cement construction. Wooden floors of buildings and porches should be some distance above the ground.

Henry Field, of the Field Seed Company at Shenandoah, informs the writer that since the wooden floors of his warehouses have been replaced with cement floors, and the basements floored and lined with cement, he has sustained little loss through the work of either mice or rats. The problem of keeping the place in a cleanly condition has also thereby been simplified.

In the construction of farm buildings such as stock barns, pig pens, and poultry houses the floors and supports should be of concrete. The above animals may be kept from actual contact with the cement by the use of dry sand or a wooden floor laid over the concrete. Corn cribs and granaries may be built entirely of concrete, or, by the use of a galvanized wire netting placed all round the inside or outside of a new or old crib, mice, rats, and sparrows may be excluded. The netting should be of not greater than halfinch mesh and of sufficient weight to resist the teeth of rats. If sparrows are not to be excluded the netting may be carried up three feet from the ground and a belt of sheet metal a foot wide nailed along its upper edge. Cribs and granarics may be built upon smooth posts high enough to prevent rats from obtaining a foothold and at the same time high enough to hold the floor well above the ground, say fourteen to twenty inches, the floor being then protected from below by wire netting or sheet metal. The floors should be as tight as possible, so that the grain may not leak through and attract the rats. By placing the floors entirely above the earth, thus leaving no hiding places for the rats, there is little inducement for the pests to make such places their abode.

An important measure in the repression of rats and mice is the keeping of food materials from them. Old buildings which cannot be easily and cheaply made rat-proof by some of the methods suggested above may be torn down and replaced with new ones as a matter of real economy. If the animals can secure food easily they breed more rapidly and the difficulties in putting into effect successful control measures are increased. Foodstuffs, forage crops, clothing, furniture and the like, if stored for a time are subject to attack with more or less resultant loss and damage. Food supplies in cellars, pantries, and kitchens may be kept safe by placing in wire-covered, rat-proof containers. The proper collection and disposal of garbage and waste from homes, hotels, cafes, slaughter 
houses, and other places where such materials accumulate is also an important factor in rat repression. Wastes, of whatever kind, should be collected in metal containers furnished with covers, care being taken that the covers are always in place. Such containers should be emptied frequently and the contents utilized in some useful manner or promptly burned.

Control Measures.-Mice are more easily trapper than rats; but with either animal it is difficult to obtain results if food is plentiful. Rats are also more cunning and suspicious than mice and this fact contributes further to the difficulty of this method of control. However, constant, consistent and concerted effort in trapping is one of the best means of controlling the pests.

One of the most efficient traps is the so-called "guillotine" trap

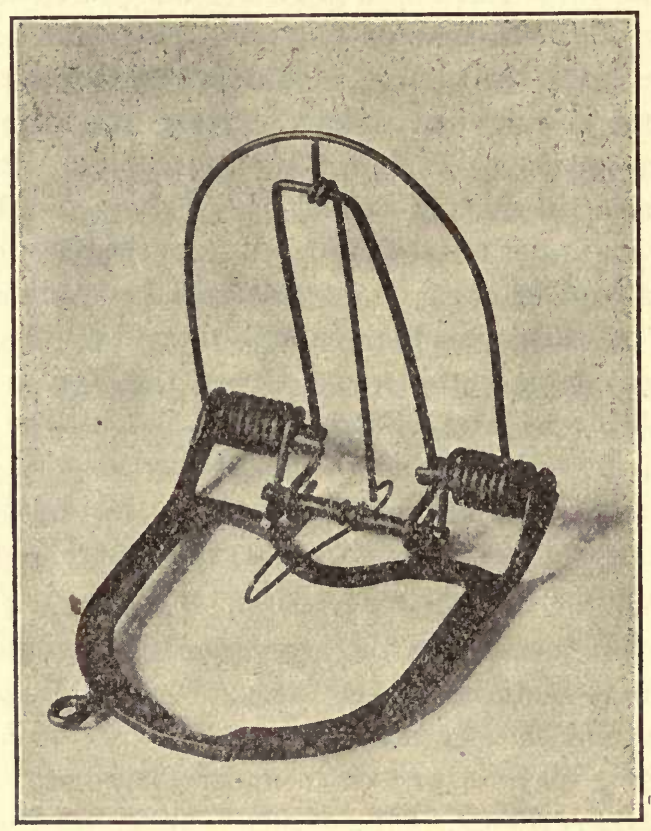

14IG. 13.-Guillotine trap made entirely of metal. (From U. S. Department of Agriculture, Bureau of Biological Survey.)

made in various styles and sizes, those of simple construction being preferable. Traps composed entirely of metal are best. In choosing a bait it is best to select some food which is not found in the vicinity. The following baits have been found excellent: Bacon, wienerwurst, oatmeal, toasted cheese, and breal (with butter), fish, 
fresh liver, raw meat, apples, carrots, corn, and sunflower or pumpkin seeds. In winter fresh vegetables such as cucumbers, tomatoes and egg-plant make excellent baits. Such baits may be placed upon the trigger plate, or the trigger wire may be bent outward and the bait placed under it. If a guillotine trap with a wooden base is used oatmeal has been found to be a most excellent bait. A number of such traps of small size thus baited will be found effective in ridding a dwelling of mice. Good results should not be expected with a small number of traps, but in an ordinary house or barn several dozen should be used.

If considerable numbers of rats are present in a building the large wire cage traps may be used effectively; but care should be

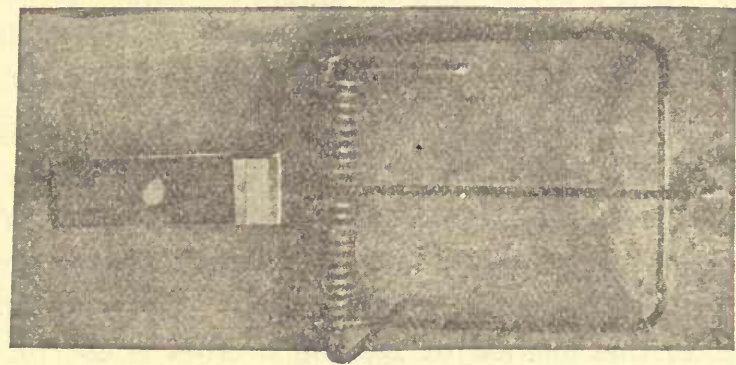

FIG. 14.-Guillotine trap with wooden base and trigger plate. (From U. S. Department of Agriculture, Bureau of Biological Survey.)

taken in purchasing such traps to see that the wires are of sufficient weight so as not to be bent by the confined rats. Such traps should be partly concealed, carelessly, and without obvious attempt. A board placed over the trap and an old cloth or sack or a bunch of straw loosely thrown over it will answer very well. Sometimes good results are obtained by placing the entrance of the trap opposite a rat hole, fitting it closely so that the rats in order to leave the hole must enter the trap. These cage traps may also be baited and left for several nights until the rats become accustomed to enter them when they should be freshly baited and closed. If a single rat is caught it may serve as a decoy to attract others. Cage traps are most effective in securing young rats, for after a little time the adult animals become suspicious of the trap and will not enter. The traps should be handled as little as possible; and some trappers make a practice of subjecting the trap, whether cage, guillotine, or steel, to the smoke of a fire and then of placing it 
with a stick or other instrument. Sometimes also gloves are worn in the setting of these traps.

The common spring steel trap (No. 0 or 1 ) may be used, but since the rat is usually caught by the foot its squeals frighten the other rats and they are made more wary. Such traps may be set in narrow runways or at the openings of burrows and covered lightly by oats or other grain. Care should be taken to keep the trigger plate free from grain. A food which is not commonly accessible will prove to be the best bait; so that in and around a slaughter house or meat market, vegetables or grain will serve best, while in a barn or granary a bait of meat will give best results. The bait should be kept fresh, should be handled as little as possible, and should be changed when a given kind no longer continues attractive. Of course other foods should be made as inaccessible as possible while trapping is in progress.

The barrel trap is reported to have been used with considerable success in some places and the method of using it may be briefly mentioned. The rats are first attracted to a given place for several nights by baits placed upon the tops of barrels covered with heavy brown paper or with a light wooden top. After the rats become accustomed to this method of feeding a cross is cut in the paper
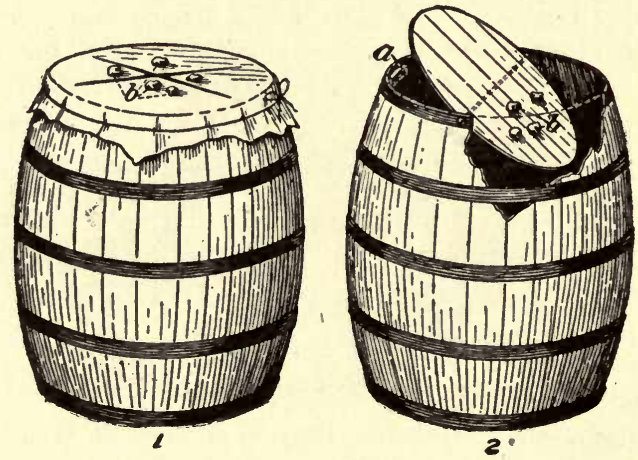

FIG. 15.-Barrel trap; 1, with stiff paper cover; 2, with hinged cover; $a$, stop; $b$, baits. (From U. S. Department of Agriculture, Bureau of Biological Survey.)

and the rats on coming to the usual place fall into the barrel. In the case of the wooden-topped barrel, the cover is hinged on a rod; and the baits are fastened to the cover which is properly weighted so that it will turn with the weight of the rat, and after the animal has been dropped into the barrel will again come to a horizontal position ready for the next victim. A stop is placed on the side 
of the barrel opposite the baits to prevent the lid from tilting in more than one direction.

Professor C. C. Nutting informs the writer of a unique but apparently successful method of driving out rats from a dwelling. He has tried it and his experience may be briefly mentioned here. Upon returning to his Iowa City home in late summer at the close of his vacation, Professor Nutting found the cellar of his house literally overrun with rats. Holes and burrows had been made in the walls and floor of the cellar and the animals were evidently well satisfied with their lot. Upon discovering this state of affairs, Professor Nutting promptly placed about two tablespoonfuls of red pepper in each burrow and rat hole that he could find. The result was that every rat on the premises disappeared very shortly and reinfestation has not since occurred.

Poisons offer one of the quickest, surest, and most efficient methods of combating mice and rats, especially around barns and outbuildings; but the odor arising from the dead animals renders this method inadvisable in occupied dwellings. Extreme caution should be observed in the use of any poison, and care should be taken not to place it or the poisoned baits where children or domestic animals of any kind can reach it. Pains should be taken, also, to see that the bodies of any rats or mice that have been killed by poison have been disposed of either by burying or burning them.

Strychnia sulphate (dry crystals) may be inserted into such haits as raw meat, toasted cheese, or wienerwurst cut into pieces. The baits are then placed along the runs or burrows. A strychnin syrup is easily made, and oatmeal, wheat or corn poisoned by soaking in this semi-liquid. The syrup is prepared by dissolving a half ounce of strychnia sulphate in a pint of boiling water; a pint of thick sugar syrup is then added, and the whole stirred thoroughly. If catmeal is used as a bait, it should be thoroughly moistened with the syrup; wheat, corn, or other grain should be soaked over night in the syrup. Smaller amounts of this poison preparation ean be made by using the proportions given above.

Barium earbonate is a cheap, effective, and comparatively slowacting poison without taste or smell; and after rats or mice have partaken of it they usually leave the premises in search of water. This feature adapts the poison, in a measure, for use in occupied dwellings. Oatmeal is a good bait, and mixed with about one-eighth 
its bulk of barium carbonate and sufficient water to form a thick dough is easily handled and distributed. The poison may also be fed in the form of a dough made of four parts flour or meal to one of the poison. It may also be spread upon moistened toast, fish, or bread and butter. Such baits may be placed in small pieces along and in the runs. If the first application does not bring the desired results another bait should be tried. This poison has a corrosive action upon the stomach lining.

Powdered white arsenic (arsenious acid) has long been used as a poison for rats, but while some rats may be killed by it others will survive and once recovered they will seldom be attracted a second time. The baits mentioned above for use with barium earbonate or strychnin may be used with arsenic. A successful method. of using this poison is to take twelve ounces of corn meal and one ounce of the arsenic to which are added the whites of enough aggs to form a heavy dough.

Phosphorus is a commonly used poison, and the writer has used it with a considerable degree of success. However, the phosphorus pastes which may be obtained at the drug stores vary to such a great extent in the proportion of phosphorus present that they can scarcely be relied upon, while in some the amount of phosphorus present renders the paste highly inflammable. Home-made preparations are liable to result in conflagrations. Phosphorus paste does not prevent decomposition of the body of the animal which has eaten it, neither do the animals leave the premises before dying. On the whole phosphorus paste is not a satisfactory poison for rodents, and its use in this respect is not encouraged.

Where rats infest buildings ard yards occupied by poultry the poisoned baits may be placed in a small wooden box over which is set a considerably larger box, bottom upward, with one or more holes in the sides sufficiently large to admit the rats. The pests thus have access to the poison while the fowls eannot reach it.

Fumigation with carbon bisulphid is effective in destroying rats in burrows in fields and along river banks and levees. Carbon bisulphid is a highly inflammable liquid which evaporates rapidly upon expasure to the air and gives off a poisinous vapor. It can be used in fumigation only where the fumes can be confined sufficiently so that the animals are asphyxiated, and for this reason is not effective in most buildings. To fumigate rat burrows take a wad of cotton or other absorbent material, saturate thoroughly with the liquid and push into the burrow as far as possible with a stick. 
The opening should then be quickly packed with earth to prevent escape of the fumes. Care should be taken that lighted cigars, pipes, cigarettes, matches, and open lights are not brought near the carbon bisulphid.

Hydrocyanic acid gas has been effectively used to destroy all animal life in buildings; and if properly used will successfully destroy rats, mice, and insects. Since this gas, however, is extremely poisonous to human life, this method of fumigation should not be undertaken by an inexperienced person without following careful and detailed instructions. Farmers' Bulletin No. 699 of the U. S. Department of Agriculture, prepared by L. O. Howard and C. H. Popenoe and entitled "Hydrocyanic Acid Gas against Household Insects," will give details regarding fumigation with this poisonous gas.

Coöperative and organized effort in the destruction of mice and rats is of very great importance. Individual and sporadic effort, while instrumental in reducing the number of pests locally, cannot bring about large results for the animals soon come in from surrounding localities where repressive and control measures have not been in vogue. Whole townships, counties, and cities should give continuous and united effort in the destruction of these pests in order that permanent results be abtained. In the city of Muscatine a bounty of one cent each is offered on rats by the city council. The bounty has been in force for about three years and has had the effect of reducing, to a considerable degree, the number of pests. While a municipal bounty is not recommended as an excellent control measure, it sometimes gives good results and draws attention to the situation, so that coöperative work is likely to meet with more popular favor.

Organized rat hunts, while effective at the time, are not of permanent value unless followed up by continued effort, which may often be stimulated by the offering of prizes. Various civic and citizens' clubs, Boy Scout troops, women's clubs and other organizations can do profitable work by encouraging a continuous campaign of destruction against the rat.

In conclusion, a summary of the important measures for repressing and eliminating rats and mice as given by Lantz in Farmers' Bulletin No. 896 may be pertinently included here:

"1. The requirement that all new buildings erected shall be made rat-proof under competent inspection. 
2. That all existing rat-proof buildings shall be closed against rats and mice by having all openings accessible to the animals, from foundation to roof, closed or screened by door, window, grating, or meshed wire netting.

3. That all buildings not of rat-proof construction shall be made so by remodeling, by the use of materials that may not be pierced by rats, or by elevation.

4. The protection of our native hawks, owls, and smaller predatory mammals-the natural enemies of rats.

5. Greater cleanliness about markets, grocery stores, warehouses, courts, alleys, stables, and vacant lots in cities and villages, and like care on farms and suburban premises. This includes the storage of waste and garbage in tightly covered vessels and the prompt disposal of it each day.

6. Care in the construction of drains and sewers, so as not to provide entrance and retreat for rats. Old brick sewers in cities should be replaced by concrete or tile.

7. The early threshing and marketing of grains on farms, so that stacks and mows shall not furnish harborage and food for rats.

8. Removal of outlying straw stacks and piles of trash or lumber that harbor rats in fields and vacant lots.

9. The keeping of provisions, seed grain, and foodstuffs in ratproof containers.

10. Keeping effective rat dogs, especially on farms and in city warehouses.

11. The systematic destruction of rats, whenever and wherever possible, by (a) trapping, (b) poisoning, and (c) organized hunts.

12. The organization of clubs and other societies for systematic warfare against rats."

\section{BLACK RAT. \\ Rattus rattus (Linnæus).}

[Mus] rattus Linnæus, Syst. Nat., X ed., I, 61, 1758.

Description.-Color above sooty or plumbeous black; fur softer and thicker than in the brown rat; the mixture of darker and lighter over hairs gives the animal a shiny appearance; color below paler than above; feet brown; tail longer than head and body.

Measurements.-Total length, 14.90 inches; tail vertebræ, 8.10 inches; hind foot, 1.40 inches. 
The black rat is not so stout as the brown rat and has a longer, more pointed head and larger and broader ears, while the tail is longer than the head and body together.

The black rat was carried from Europe to South and Middle America about 1554 but the time of its arrival in the North American colonies is not definitely known. Apparently it had become well established in the settled districts by the beginning of the eighteenth century; but with the appearance of the brown rat the numbers of the black rat began to decrease, and in most localities it is no longer present.

In the United States the black rat is still found in some parts of the South; a few colonies occur in Canada and in some states east of the Mississippi. At some seaports like San Francisco and the immediate coastal islands, it is probable that numbers of this species are introduced in shipping from the far East, but these individuals are usually destroyad before they have much opportunity to reproduce their kind. So far as our neighboring states are concerned the black rat has been recorded from Wisconsin, Indiana, Tennessee, and Kentucky. The species was first recorded from Iowa by Professor Herbert Osborn in 1888, and to the record he adds the statement, on the authority of Jordan, "being supplanted by preceding"' [Rattus norvegicus]. ${ }^{9}$ This rat is again recorded from the state by the same author in 1891, without comment. ${ }^{10}$ The writer is not familiar with any other records of the occurrence of this form in Iowa, and it is probably no longer found within our borders.

NORTHERN WHITE-FOOTED MOUSE. WOODLAND DEER MOUSE.

Peromyscus leucopus noveboracensis (Fischer).

[Mus sylvaticus] Noveboracensis' Fischer, Synopsis 'Mamm., 318, 1829.

Description.-General color above brown, slightly darker along middle of back; ears dusky, narrowly margined with white; whiskers blackish above, white below; tail thickly clothed with hair, brownish above and gradually shading into white below; feet white;

\footnotetext{
'Osborn, Herbert, Catalogue of the Mammals of Iowa, Proc. Ia. Acad. Sci., I, 43,1888 .

${ }^{10}$ Osborn, Herbert, A Partial Catalogue of the Animals of Iowa: Ames, Iowa, 5,1891 .
} 
color below white, entirely concealing the slaty undercolor; entire pelage long and soft.

Measurements.-Total length, 7.00 inches; tail vertebræ, 3.00 inches; hind foot, 0.87 inch.

This is the best known of the white-footed mice, since it is most common in thickly populated regions of the United States, including such districts in Iowa. The name "deer mouse" apparently has been given this animal on account of the supposition that the seasonal change in color corresponds to that of the Virginia deer. Adult mice do not show so much seasonal difference as the deer, the main difference being in juvenile and adult pelage. While the pelage of the adult mouse is almost constantly changing such change is due to wear and fading, there being but a single annual molt, which occurs in summer or early fall.

Habits, Distribution, Etc.-The northern white-footed mouse is partial to wooded areas, although in summer it is often found in pastures where old stumps and bushes occur. In no case, however, is it found far from woods. Sometimes old corn and small grain shocks along the edges of woods are used as homes. This mouse is mainly nocturnal in its habits, though occasionally it goes about during the day. It wanders about freely and makes no beaten runways, though undoubtedly it often utilizes those made by other rodents, especially meadow mice. This form burrows very little, the most ambitious undertaking in this direction usually being a simple, shallow runway under a log or other object. Though living largely on the ground it is to some extent arboreal and can climb trees almost as well as a squirrel.

The nests are built in or under an old hollow log or stump, in some cases in a pile of brush or in bushes. Often these mice occupy the deserted nests of woodpeckers or chickadees, and again they may use either temporarily or permanently a bird's nest in a small bush. Frank C. Pellett reports having found them living in hollow limbs in the top of a large tree. The nest is usually composed of small twigs, leaves, and grass and when on the ground is reached by short, underground tunnels. On April 13, 1914, near Bayfield, the writer turned over a small hollow log and found a nest of this form occupied by a single individual. The nest was composed entirely of grass, and was on low land, near water in a sparsely wooded area; the nearest buildings were about one mile distant. 
This white-footed mouse does not hibernate, but is active throughout the winter, and stores up grain and seeds for use during cold weather. It is very prolific, usually bearing from four to six young at a time, and it breeds throughout the year; so that, ordinarily, two or three litters are produced in a season.

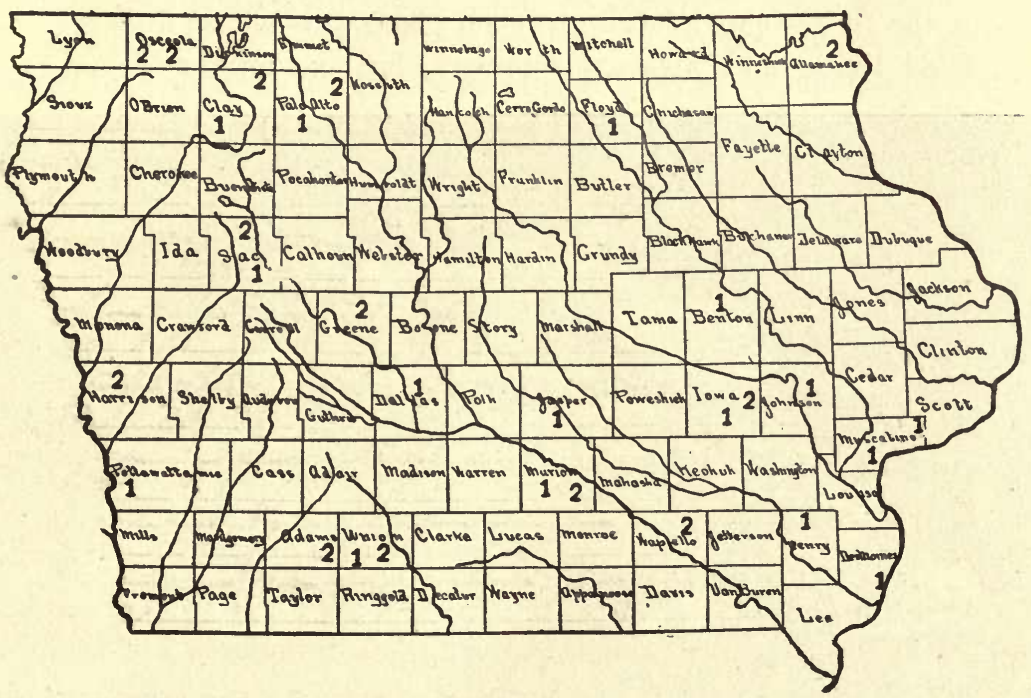

FIG. 16.-Map showing locality records of-

1. Northern White-footed Mouse (Peromyscus leucopus noveboracensis).

2. Prairie White-footed Mouse (Peromyscus maniculatus bairdi).

This mouse is distributed throughout the state, and in some localities, particularly in wooded areas, is quite abundant. The localities represented by specimens are Wayland, Bayfield, Burlington, Fairport, Thayer, Wall Lake, Iowa City, Charles City, Homestead, and Newton. It has also been recorded from Knoxville, Redfield, Council Bluffs, and from Clay and Palo Alto counties.

Food Habits, Economic Importance, Etc.-The northern whitefooted mouse does not feed to any great extent upon green plants as do the meadow mice; its food consists mainly of nuts, acorns, the seeds of maple and other trees, grain in the fields, and seeds of noxious weeds. It is also very fond of basswood seeds, the pits of wild cherries, and the seeds of many wild shrubs and grasses. "In wooded regions or on waste land, where it commonly lives, it is not very injurious to agriculture; but when living about the edges of cultivated ground it sometimes devours or carries away grain in considerable quantities. . . . It occasionally gnaws the 
bark of young fruit trees or nursery stock, but such harm is more often due to meadow mice (Microtus)." "11

This species often enters out-buildings and even houses, particularly in rural districts and communities in which the house mouse has not become established, for the latter mouse seems able to drive away the white-footed form. In such places this mouse finds a comfortable living and pleasant quarters, but commits more or less

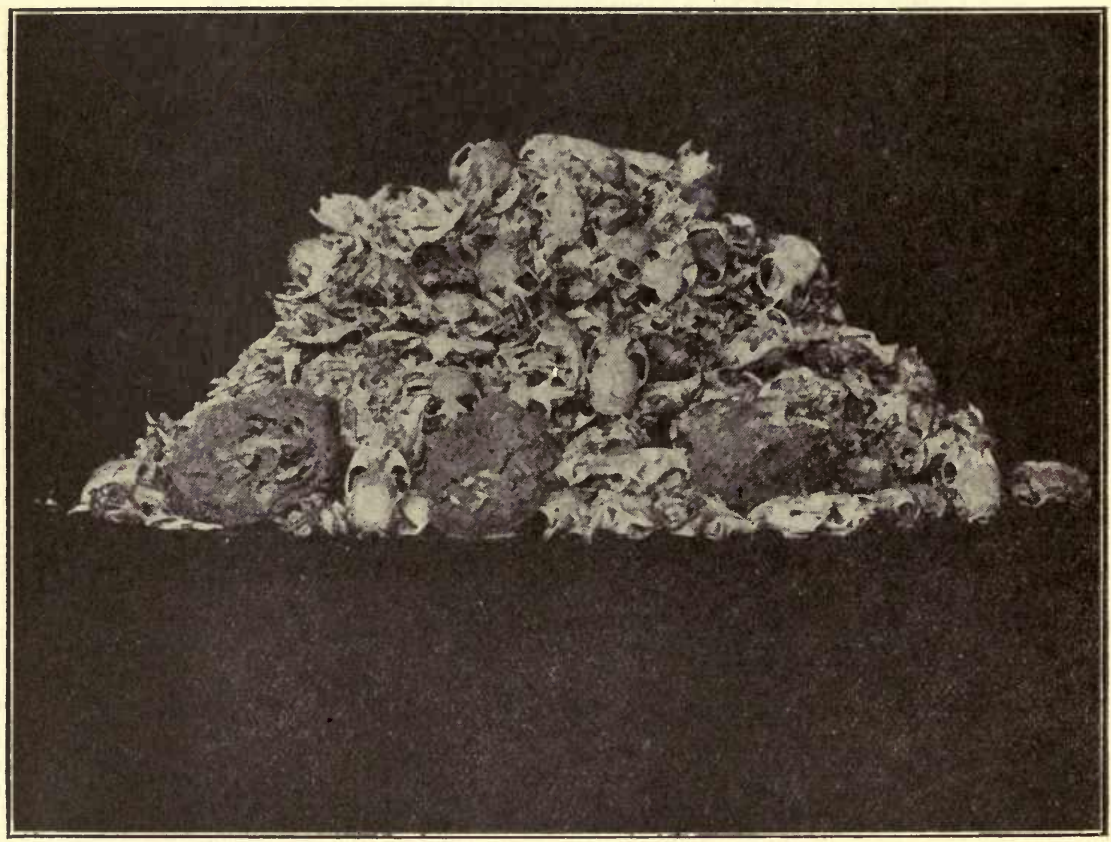

FIG. 17.-Field-Mouse skulls taken from pellets found under owl roost in Smithsonian tower, Washington, D. C. (From U. S. Department of Agriculture, Bureau of Biological Survey.)

depredation in the way of cutting up cloth for nesting materials and destroying foodstuffs and provisions of various kinds. Sometimes damage is done in granaries and in hay and straw stacks. Since this mouse is so prolific, and since it is mainly nocturnal in its habits, with the result that it is not much attacked by hawks, its numbers in a given locality may increase considerably above normal with resulting injury to agricultural interests. However, in no case has the writer heard specific charges of serious damage against the northern white-footed mouse in the state, although it is probable

${ }^{11}$ Lantz, D. E., N. A. Fauna No. 28, 27, 1909. 
that damage may have occurred and have been attributed to the house mouse. Of course owls, weasels, and the larger harmless snakes destroy numbers of white-footed mice; and, in addition, domestic dogs and cats occasionally kill them. They can be kept off one's premises only by constant vigilance, since any decrease in the supply is immediately made good by invasion from neighboring wocds and fields. When these mice infest houses and other buildings, they may be destroyed by trapping (the common snap traps are good), or by poisoning. Strychnin in the form of strychnia sulphate is one of the best methods of poisoning. One ounce of the poison is used for one-half bushel of wheat. The strychnia sulphate is first dissolved in a pint of hot water, after which a pint of heavy syrup or molasses is added. This poison fluid is now poured over the wheat and the mass stirred until each grain is coated, when the whole is left for from twelve to twenty-four hours before it is distributed. Care should be exercised that birds and live stock are not allowed access to the poisoned wheat either in bulk or after it has been distributed.

\section{PRAIRIE WHITE-FOOTED MOUSE. PRAIRIE DEER MOUSE.}

\section{Peromyscus maniculatus bairdi (Hoy \& Kennicott).}

Mus bairdii Hoy \& Kennicott, in Kennicott, Agricultural Report, U. S. Patent Office (1856), 92, Pl. XI, 1857.

Description.-Winter: Color above brown mixed with black, the latter confined to middle of back; sides paler than back; sides of face paler than top of head; ears brownish black narrowly margined with creamy; tail sharply bicolor, black or blackish brown above, white below; feet white; color below white or whitish, the tips of hairs white, their bases slaty gray; the dark bases are not concealed and this gives a grayish tinge to the under parts. Summer: The worn pelage becomes brighter and the dark dorsal line reduced and changed to pale brownish.

Measurements.-Total length, 5.75 inches; tail vertebræ, 2.45 inches; hind foot, 0.70 inch.

This form is similar to the northern white-footed deer mouse, save that the ears and feet are smaller and the tail markedly shorter, more thickly haired, and more sharply bicolor; in addition, the general color is darker than in that species, and the entire animal is decidedly smaller. 
Habit's, Distribution, Etc.-The prairie white-footed mouse seems to be confined to the open prairie and cultivated fields of the Mississippi Valley. In Iowa it is distributed practically throughout the state and seems to be at least no less common than the northern white-footed mouse.

This mouse inhabits dry cultivated fields and prairies, and, to some extent, is found in small sparsely wooded areas. Ruthven and Wood report that the nine specimens secured in Clay and Palo Alto counties "were found in burrows in stubble fields, pastures and on the shores of lakes." ${ }_{12}$ Robert Kennicott, who many years ago made extensive observations on this animal, reports as follows concerning its habits: "Not having on the prairies, the shelter found by its timber-loving cousins in old tree stumps and trees this species digs burrows. These are rather simple, with few or no side-passages, and often with but one entrance, the depth and extent being variable, but never great. The nest is small, composed of soft grass, etc., it is spherical, and the small internal cavity is entered through a narrow opening on one side. In cultivated fields the burrows are frequently dug at the roots of fruit trees, the bark of which is often gnawed, sometimes causing great injury. In nurseries, fruit-trees are often taken up and 'heeled in'; that is, laid down close together, with the roots placed in a trench, and then covered in such manner that they are kept safely in a very small space, and can be readily pulled out when desired. The loose earth among the roots of these offers an inviting habitation to the mice; and, in nurseries infested by them, they will be found burrowing in almast every lot of trees thus buried, where they feed upon the bark of the roots, and thus cause serious damage. In the fall, they are often found in cornshocks, making a nest among the stalks, though they do not so often burrow under these as the arvicolae. But, during winter, they may be tracked in corn-fields from their burrows to the neighboring cornshocks, which they have visited for food. In spring, the young are always produced in burrows. During the summer, however, they occasionally are observed in nests, under bits of wood or bunches of hay, on the surface of the ground. In autumn, I have found nests of the young in small burrows only a few inches below the surface, or under an inverted sod. I have never observel more than one nair of adults occupying the same burrow; and, unlike

1eRuthven, A G., and Wood, N. A., Proc.'Ia. Acad. Sci. XIX, 204, 1912. 
the Mus leucopus [White-footed mouse] this species never appears to be gregarious.

"I have found the young in March and April, and observed two females, each with five young, apparently but a few days old, about the tenth of November, while they are found in every intervening month. In nearly every instance within my observation the number of young produced at a birth has been five. I once found six, and have at times, though rarely, seen three or four. The young are attached to the teats, as in the species last described; and a female was seen to carry five for several rods in this way, jumping along rapidly despite their weight. As soon as they are able to take care of themselves, the young leave the mother. In summer, I have several times found one apparently but a few weeks old, living alone in a nest made by himself. In spring, I have always found the old male living with the female and young; but during the summer, I have sometimes observed the male leading a solitary life, and the females and young in burrows by themselves. The food of this mouse, on the prairies, appears to be herbaceous plants, with their seeds; but I have been unable to see that it ever digs for roots. It is interesting to observe that this, like the Mus leucopus, seeks its food on the top of the ground, running on the snow in winter in search of seeds, and collecting them in autumn instead of rocts, when it travels as often by springing over the grass as by running through it. This mouse probably feeds more or less upon insects, as it is carnivorous in captivity; though some specimens are much less so than others." 13

On November 10,1917, the writer received from Vinton an adult female example of this form along with four young apparently less than a week old. The latter were scantily haired and had the eyes closed. This family was found in a burrow about five inches deep in the soil. No evidences of stored food were found in the burrow. The measurements of the young are as follows:

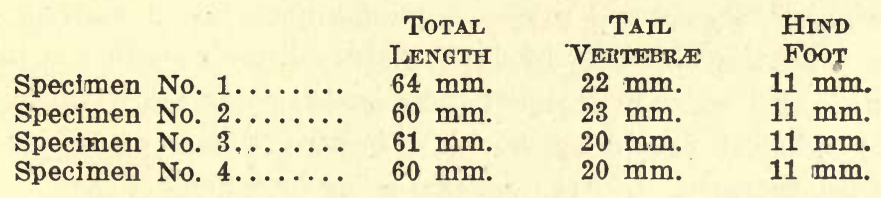

NotE-Since the specimens were so small the measurements are given in millimeters instead of fractions of an inch.

${ }^{13}$ Hoy \& Kennicott, in Kennicott, Agr. Rept. for 1856, U. S. Patent Office Rept., 93-94, 1857. 
Of course in localities where these mice are abundant they cause some damage to grains, orchards, and nursery stock. Since they are abroad during the daytime more than the preceding species, they are subjected to the attacks of a greater number of enemies than are the northern white-footed mice, a fact which serves to keep down their numbers somewhat. Skunks, minks, weasels, hawks, owls, crows, herons and bitterns, the larger harmless snakes, and domestic dogs and cats are all efficient in keeping down the numbers of this mouse.

Of the control measures which may be employed, those offered in the discussion of the preceding species will be found effective. A further suggestion as to method of poisoning may be mentioned here and one which has the advantage of not placing in danger the lives of domestic animals and birds. Instead of scattering the grain on the ground, place the poisoned wheat in short pieces of drain pipe, having a diameter of one ard one-half inches. The pipes are then placed on the ground near the burrows or nests where the mice may readily enter.

This seems to be the more abundant of our white-footed mice, and many specimens are at hand from Corning, Jefferson, Thayer, Wall Lake, Ottumwa, Melvin, Waukon, Rodman, Ocheyedan, Logan, and Homestead. The species has also been recorded from Knoxville and from Clay and Palo Alto counties. See also the map on page 71 .

\section{PRAIRIE HARVEST MOUSE.}

Reithrodontomys megalotis dychei Allen.

Reithrodontomys dychei Allen, Bull. Am. Mus. Nat. Hist., VII, $120,1895$.

Description.-Winter: Color above brownish buff mixed with black, the middle line above in many cases noticeably darker; sides grayish buff, the lateral line on some specimens well marked; ears brownish, thinly clothed with bufiy hairs on inner surface, a tuft of brownish buff hairs in front of their bases; color below white; feet white; tail dark brown above, white below. Summer: Colors less strongly contrasted and the general color browner.

Measurements.-Total length, 5.25 inches; tail vertebræ, 2.25 inches; hind foot, 0.65 inch. 
This little mouse has somewhat the appearance of Goss's lemming mouse; but the present form is browner above, lighter below, lacks the dusky mark at the base of the whiskers, and has the groove on the upper incisors (front teeth) near the middle of the tooth rather than near the outer edge. In addition, the molars of the upper jaw are furnished with rounded points or tubercles on the crowns extending in two longitudinal rows, in place of the irregular triangles shown in Goss's lemming mouse.

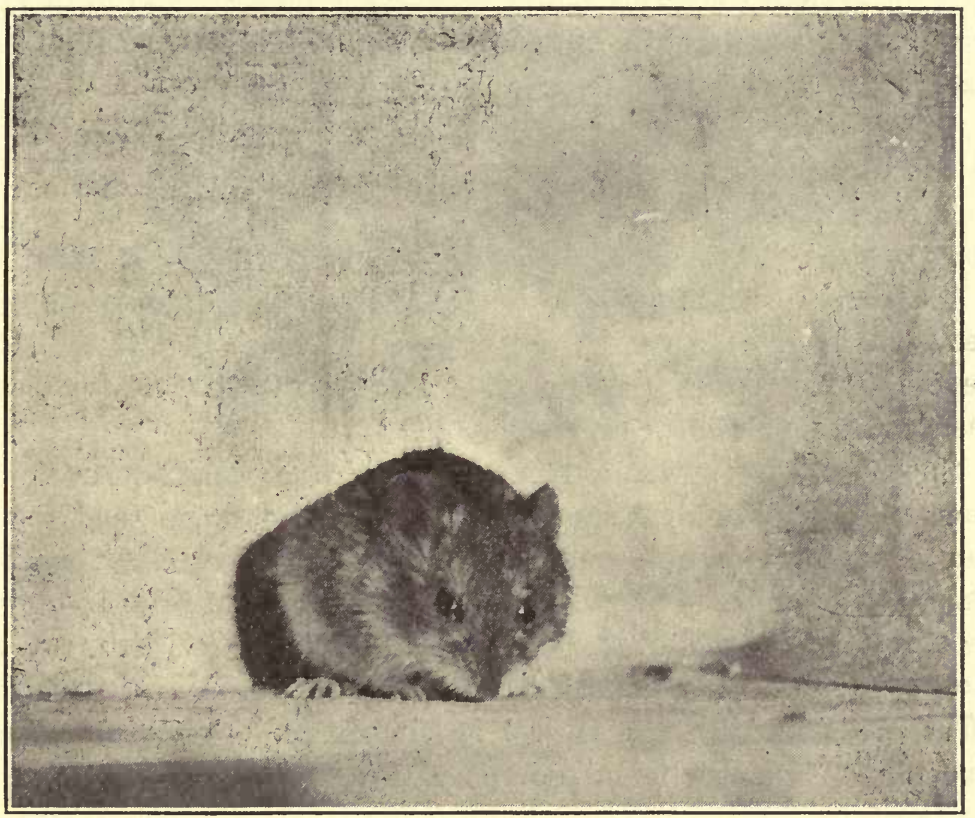

Fig. 18.-Prairie Harvest Mouse. Photo from life by Frank C. Pellett.

Habits, Distribution, Etc.-The harvest mice, to which group the present form belongs, all live in more or less neglected, open, grassy fields and along the edges of cultivated fields. Although they live for the most part above ground, sometimes burrows and crevices are used in which to construct their nests. These nests are built of grasses lined with soft material. The prairie harvest mice sometimes travel in beaten paths of their own making or in runways made by meadow mice. They do not hibernate and are about both at night and during the day.

The prairie harvest mouse molts only once a year, in late fall, but marked changes in pelage are to be noted from other causes, namely, 
fading and wear. Not much evidence of wear is shown before early spring; but as the tips of the hairs wear off the pelage becomes redder, and by the middle of the summer it shorrs indications of considerable fading.

Grain, seeds, and green vegetation form the principal articles of diet of the prairie harvest mouse. From the fact that it prefers more or less neglected areas overgrown with native plants which are of no value or of only slight value to the agriculturist it is evident that, in Iowa at least, this mouse does little damage. Add to this the fact that it is apparently not common in any locality and the likelihood of damage is also lessened.

In Utah the species is reported as eausing some damage by climbing grain stalks and cutting off the heads. It is also reported that in eastern Kansas this form is found under shocks of wheat and corn in the fall and that in such situations it takes some grain.

This is a western form that is apparently working its way to the east and north; the records given below indicate that it is pretty generally distributed throughout the state, although nowhere does it seem to be abundant or even common.

Specimens are at hand from the following localities in Iowa: Iowa City, Wall Lake, Atlantic, Ottumwa, Tama, Logan, and Jefferson. This form has also been recorded from Fairport, Hillsboro, and Palo Alto county. These records indicate that the prairie harvest mouse is distributed rather sparingly over practically the entire state; though Mr. Pellett reports that it is common in the vicinity of Atlantic and he has several specimens in his collection from that place. See also the map on page 107.

\section{MEADOW MOUSE. MEADOW VOLE.}

Microtus pennsylvanicus pennsylvanicus (Ord).

Mus pennsylvanica Ord, Guthrie's Geography, 2d Amer. ed., II, 292, 1815.

Description.-Color above reddish brown to yellowish chestnut, mixed with blackish hairs; sides lighter, the lower sides yellowish brown; feet brownish with six calloused tubercles on the soles; tail dark above, paler beneath, and more than one-third the length of head and body; color below grayish white, on some specimens faintly washed with cinnamon brown.

Measurements.-Total length, 6.50 inches; tail vertebræ, 1.70 inches; hind foot, 0.85 inch. 
This is our most common representative of this section of the family; and, in addition to the characters above mentioned, it is to be distinguished from the following closely allied form by the number of teats, which is eight. In winter the fur is longer and duller colored than in summer.

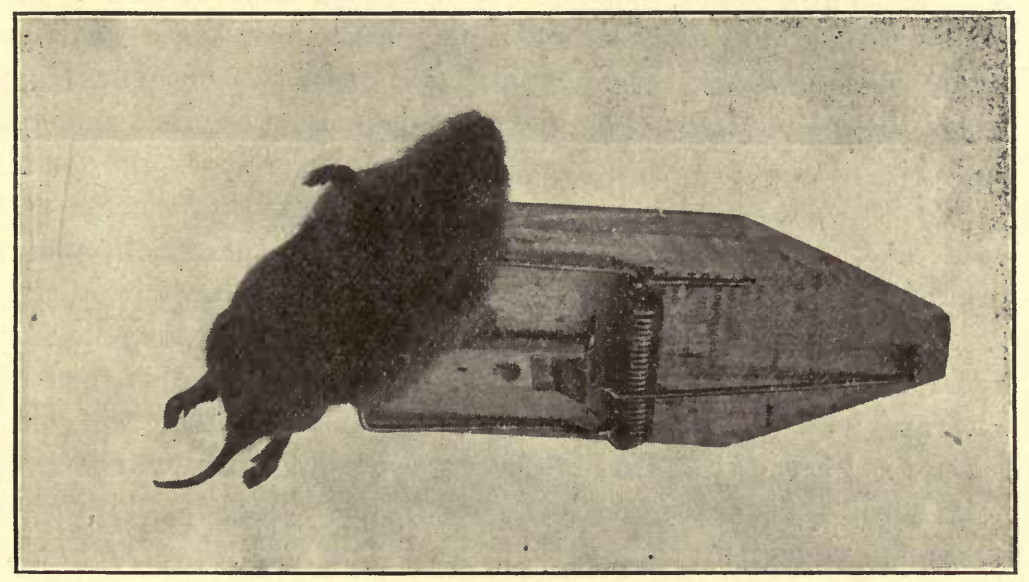

FIG. 19.-Meadow Mouse caught in a guillotine trap. (From U. S. Department of Agriculture.)

The meadow mice proper, of which there are three forms occurring in the state, and of which this is the first to be discussed, are to be recognized in general by their stout bodies, the short, round and hairy tail, the blunt, rounded muzzle, and the short ears, which in winter are almost concealed by the fur. The fur is long, that of the back being mixed with still longer hairs.

Habits, Distribution, Etc.-The meadow mouse is common throughout the state in moist meadows and in the grassy borders of marshes and wooded swamps. It is not uncommonly found in dry pastures, cornfields, uncultivated or waste fields, and in rpen spaces bordering timber land. Most meadows are infested with these animals, and in the proper situations their trails are quite evident. In swamps these paths often cross mud flats and even shallow water, and where deep snow has melted or where dry grass has been burned off the network of runways can be seen without difficulty. In the construction of these trails meadow mice utilize many kinds of low shelter, such as fallen weeds, leaves, and grass under which the trails take on the nature of half-tunnels. These trails lead to the roots of food plants and to underground nests, and are also used as 
places of refuge. The meadow mouse is often seen in daytime, and is not so nocturnal in its habits as are many of the related forms. It is especially active in the evening and early morning.

The nest is usually constructed in burrows which follow along under clumps of grass above the surface of the damp ground. It is made up of grass or strips of weeds, coarser materials being used on the outside and finer stuff within. Each nest has a small entrance hole near the bottom from which run two or more trails. One of these often leads to an underground tunnel opening some distance from the nest. Nests in which the young are born are usually lined with some soft material such as the "cotton" from the milk weed or. "eat-tail." Such nests are ordinariy placed in underground burrows. If a nest is destroyed a new site is immediately chosen, fresh materials are secured, and another domicile constructed often in a single night. When the home is disturbed the occupants rush about without much idea of where they are going, and are as likely to go towards the source of danger as away from it. Apparently their eyesight is not good in the sunlight. If a way of escape is not evident, they will put up a fight with claws and teeth.

Ordinarily two, in some cases three litters of young are produced in a season, the number in a litter ranging from four to eight with six the average number." The young are born blind and hairless. The breeding season extends over most of the year except midwinter. D. E. Lantz says: "The common meadow mouse (M. pennsylvanicus) is one of the most prolific of the American species. If six young, the average number, are produced at a birth, and four litters in a season, and if no enemy or disease check the multiplication, the increase would be appallingly great. A single pair and its progeny would in five seasons amount to over $2,000,000$. This calculation is conservative being based on the theory that the young of one season do not breed until the next year-an assumption that is likely to be incorrect; for, the animals mature very quickly, and the young born in spring probably breed in the fall of the same season. If a thousand pairs of meadow mice survive a winter in any locality, it is easy to understand how, after two or more seasons of uninterrupted increase, they might become a menace to agricultural interests." ${ }^{14}$

Dr. C. H. Merriam in discussing this species says: "In the beginning of winter, when the ground is frozen for some distance be-

${ }^{14}$ Lantz, D. E., Meadow Mice in Relation to Agriculture: Yearbook, U. S. Dept. Agr., 367, 1905. 
low the surface, it abandons its burrows and lives entirely a'sove ground. Its nests of dry grass then lie flat upon the surface, without attempt at concealment and are soon buried in the snow. As winter advances and the snow becomes deeper, the Meadow Mice regularly betake themselves to their nests for rest. The heat from their bodies soon melts the snow in contact with and immediately adjoining the nests, which, from the continued operation of the same cause, come to be surrounded by slowly-growing, dome-shaped chambers. These increase in size until the spring thaws in March and April, melt away their roofs, thus admitting the light and cold. They are then deserted." 15

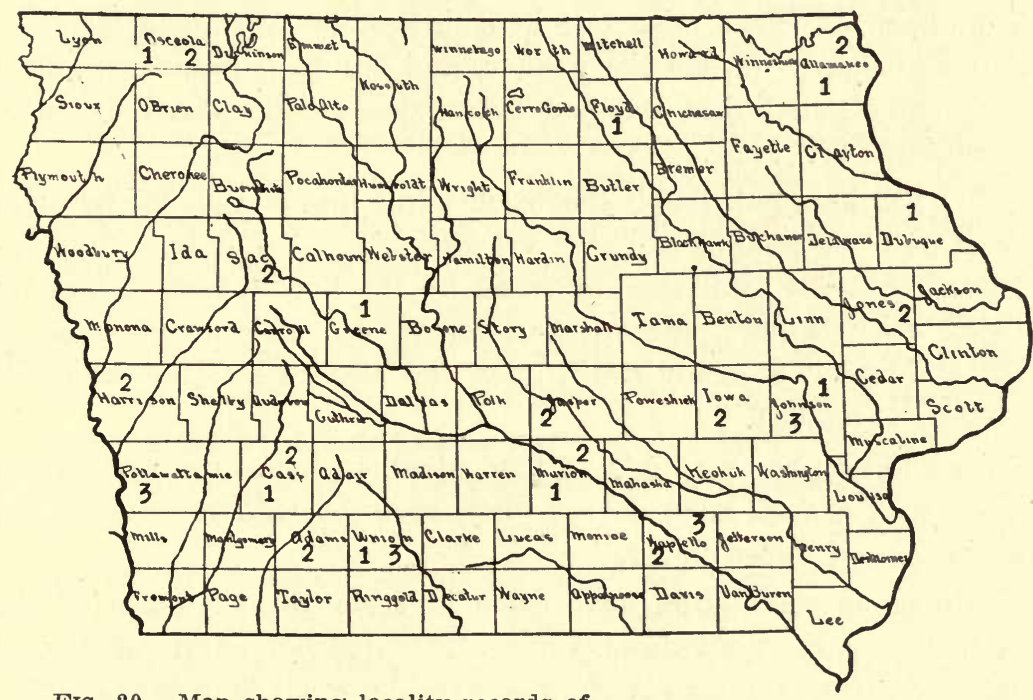

FIG. 20.-Map showing' locality records of-

1. Meadow Mouse (Microtus pennsylvanicus pennsylvanicus).

2. Prairie Meadow Mouse (Microtus ochrogaster ochrogaster).

3. Woodland Vole (Microtus pinetorum nemoralis).

This form has been included in the earliest lists of Iowa rodents and is one of the most abundant species of the group. It is found in practically every locality in the state. Specimens are at hand from the following places: Melvin, Thayer, Atlantic, Jefferson, Waukon, Charles City, and Iowa City. It has also been recorded from Knoxville and Luxemburg.

Food Habits, Economic Importance and Control Measures.-In summer the food of the meadow mouse consists mainly of green

${ }^{15}$ Merriam, C. H., Mammals Adirondack Region, 272, 1886. 
vegetation and of the roots and seeds of grain and grasses. In winter grain and various kinds of roots are substituted for the leaves. and stems. If green vegetation is lacking, young apple orchards, forest trees, or shrubbery are often attacked if they are convenient and considerable damage is done. Such depredations occur most often in winter, though they are not confined to this season, for summer girdling of trees has been noted in many instances.

"Stomach examinations show that in addition to bark, green leaves, and seeds of grasses and sedges, field mice eat all kinds. of bulbs, tubers, and roots and occasionally animal food. The larger aquatic species are said to eat mollusks, and crayfish. When a number of these mice are kept in confinement, the stronger animals usually devour the weaker, and our field naturalists have frequently noted that trapped field mice are devoured by their brethren............

"It has been calculated that each adult meadow mouse requires from 24 to 36 pounds of green vegetation per year. It is thus apparent that the total amount eaten by the hordes that ordinarily infest the meadows, swamps and forests of our country is incalculable, and is a steady drain upon the resourees of the farnır." (Lantz, l. c. 368).

In addition to the kinds of food mentioned, the meadow muse feeds to a considerable degree upon roots of wild morning-glory, cat-tails, and sweet clover.

Numerous complaints have come in from various parts of the state concerning depredations upon trees, pastures, and gardens by meadow mice. Damage is often more widespread than is ordinarily believed, since injury actually caused by the meadow mice is often attributed to rabbits and gophers. Damage done by meadow mice can usually be recognized by the small, narrow tooth-marks and by the fact that it is lower down on the trees than that ordinarily done by rabbits. In consideration of the great prolificacy of the species and the large amount of food required by a single individual during. a year it is evident that where local conditions have been favorable to an undue increase of the animals considerable loss to agricultural interests is sure to follow. Where meadow mice are present even in normal numbers the loss though not serious may be worthy of consideration in these times of conservation.

The meadow mouse works under the snow in winter, burrowing along the roots of clover, timothy, and other plants, often destroying. 
an entire meadow. Damage is more likely to occur where the growth is long and thick than in closely pastured meadows. This sort of damage is most noticeable in late winter or early spring.

Meadow mice also do much damage to truck crops, and are especially destructive to strawberry, raspberry, currant, blackberry, and rose bushes and also to grape vines. Since the various berry ljeds just mentioned are often mulched, the material thus used affords hiding places and covering for the burrows. The animals are especially fond of the crowns of strawberry plants. Many growing vegetables, such as potatoes, beets, parsnips, carrots, celery, etc., are attacked by meadow mice, and in autumn when these vegetables are left in piles for a few days considerable damage may be done to them.

Corn, wheat, oats, rye, barley, and other growing crops are sometimes cut down and eaten. Corn is attacked mostly in the shock, while some of the small grains also are thus attacked. At Osceola and Corning such damage has been reported. Not only is the grain eaten, but a portion is also lost or covered by earth so that, on the whole, the net loss is often considerable. Alfalfa and clover also are subject to the attacks of this mouse with considerable resultant damage as reported from some parts of the state; fields of red clover in some cases have to be plowed up and planted with another erop.

The list of trees and shrubs attacked by these mice is a long one and includes practically all those grown ky the horticulturist. Among the trees most liable to injury are apple, plum, pear, peach, cherry, sugar maple, oak, ash, cottonwood, willow, and wild cherry. Other forest and fruit trees often suffer also. Damage to standing nursery stock is often done when the ground is covered by deep snow, under which conditions the trees are not only girdled but the mice often burrow down along the trunk and attack the roots. Trees recently transplanted from the nursery to the orchard seem to be favorite objects of attack, although trees five to six inches in diameter are also damaged and in some cases are killed. Since small orchards are frequently planted for family use only and hence, on account of the care demanded by other crops, in many instances are neglected and grow up in weeds and grass, they afford excellent hiding places for meadow mice and encourage them to remain throughout the season in the presence of a continuous and abundant supply of food. 
Meadow mice inflict considerable damage in parks and lawns by destroying shrubs, vines, bulbs and herbaceous plants. In some cases the straw or grass used to protect delicate plants in winter affords shelter and hiding places for the animals. Low hedges also afford shelter under which the mice construct their burrows.

Meadow mice are not, for the most part, inhabitants of waste lands, but of more or less cultivated regions; and in consideration of their food habits as above described they must be considered as injurious. That they are, to a slight extent, valuable as tillers of the soil and as destroyers of noxious seeds cannot be denied, but the slight good done in this way is more than offset by their destructive qualities. An invasion of these mice into an agricultural community would cause disastrous results, so that preventive and control measures should be continually encouraged and engaged in. In view of the fact that the meadow mouse is so widely distributed, that its habitats are usually inacessible in ordinary control measures, and that the species is so prolific, complete extermination is impossible. However, the numbers may be materially reduced in any locality, so that crops may be rendered comparatively safe from serious attacks.

There are a number of natural agencies which cannot be left out of consideration in the repression of meadow mice. In this connection Lantz says: "Climatic conditions so strongly influence the natural increase of field mice that an understanding of their relation to such increase is important. It has often been noticed that the period of greatest abundance of voles follows one or more open, warm winters succeeded by wet summers. If at the same time food - particularly grain-is abundant, the most favorable conditions for the increase of the animals are present, and the maximum number of young at a birth, as well as the maximum number of litters, are brought forth. When grain is abundant the young of some species are said to begin to reproduce when only 2 months old.

"The continuance of favorable conditions for two or more years is sure to be followed by an enormous increase of field mice, with serious injury to crops.

"Very cold winters without snow and summers of long droughts are unfavorable to the increase of field mice. Occasionally a severe frost following a heavy downpour of rain destroys nearly all field mice over large areas." "16

${ }^{16}$ Lantz, D. E., An Economic Study of Field Mice : U. S. Dept. Agr., Biol. Surv. Bull. No. 31, 37, 1907. 
One reason that may be advanced as to the causes of increase of rodent pests, meadow mice included, is the almost universal desire of man to destroy any living thing; and many of the birds, mammals, and reptiles thus thoughtlessly destroyed are among the forms which are particularly effective in keeping down the numbers of just such pests as we are now considering.

Of our wild mammals wolves, foxes, skunks, minks, weasels, and shrews are efficient destroyers of meadow mice; and this coupled with the fact that some at least, destroy noxious insects affords a measure of compensation for the damage they do.

Of the birds hawks, owls, crows, shrikes, herons and bitterns are very effective in the destruction of these mice. The red-tailed hawk, the brcad-winged hawk, and the sparrow hawk are worthy of special mention; and what farmer has not seen a shrike pounce down upon a luckless mouse and carry him away to be torn to pieces on the top of a post, or impaled upon a barb wire fence or thorn of an osage-orange bush. Crows destroy young mice in the rests anil sometimes also kill the adults. Of the owls the barn owl, long-eared owl, short-eared owl, and barred owl are especially efficient as destroyers of meadow mice.

Snakes subsist largely upon a diet of insects and small rodents, the latter standing second in importance on the bill of fare The blue racer, bull snake, hog-nosed snake, and larger garter snakes all destroy meadow mice. Most people do not realize the important service that the harmless snakes do for agriculture, but, due merely to their prejudice, destroy any and every snake wherever and whenever it is possible.

Domestic dogs and cats perform some service in the destruction of meadow mice, but cats are liable to roam widely and in their wanderings destroy young birds, which seem to be preferred to the mice.

Prevention of damage is more easily effected than a cure, and some of the preventive measures that have proved most effective will be briefly mentioned. Drainage of swamps and the clearing of waste places will destroy the breeding grounds and situations offering shelter to the mice. Clean cultivation in field, orchard and nursery, one of the most effective of the preventive measures, is highly recommended along with rotation of erops, while the burning of weeds, dry grass, and rubbish about those plots will elimisate the hiding-places of the mice and lessen the likelihood of damage. 
The clean mowing of grass lands and meadows, so that old grass is not left over winter, also produces the same results. And finally, the destruction of the natural enemies of the mice should be avoided as largely as possible and not indulged in indiscriminately.

Destruction of trees or nursery stock may be eliminated by using a lime-sulphur wash, which while very effective is also very cheap. To make the wash use twenty pounds unslaked lime, fifteen pounds flowers of sulphur, and water to make forty-five to fifty gallons. Boil in an iron, kettle at least an hour before application, which should be made by means of a brush or in the form of a spray while the mixture is yet warm.

If trees have already been girdled by meadow mice, prevention from decay and possible death is desirable. When these injured places are subjected to the weather the bark dries and the trees die; while if the wounded places can be covered so is to exclude the air, new bark will form and the injured parts will heal quickly. A quick and efficient remedy is to mound up the trunks of the trees with soil until the wound is covered, making due allowance for settling. These mounds should remain in place all summer. Nursery stock if only slightly injured by mice may in some cases be saved by covering over the wounds with grafting wax or soil. The wounds will heal over in one season.

Trapping is a simple and effective method of destroying meadow mice, but is not adapted to large or heavily intested areas since results are slow. However, if the infested area is small, such as a lawn or garden where the number of mice is limited, this method is efficient, and if persisted in the mice may be practically exterminated. Meadow mice will not enter cage traps, so the guillotine or simple wire snap trap which kill instantly are preferable. They are to be set with or without bait across the runways of the mice. Cornmeal or oatmeal may be used successfully as a bait.

The most satisfactory method of destroying meadow mice is through the use of various baits poisoned with strychnin. To prepare the poison dissolve a half ounce of strychnia sulphate in a pint of boiling water and add a pint of thick syrup. Stir thoroughly. This quantity is sufficient to poison a half bushel of wheat or corn, every grain of which should be thoroughly coated. If a smaller amount is desired use the same proportions. The poisoned bait should be placed under boards or other shelter so as to exclude birds but admit mice. Pieces of drain tile about one and one-half 
inches in diameter may be laid along the trails and the baits inserted with a spoon. Other baits, such as oatmeal and the seeds of dandelions or sunflowers may be used in place of the wheat or corn.

In winter a good method of destroying meadow mice as well as rabbits is to cut small twigs from apple trees, dip them in the strychnin syrup, and distribute them about the trees to be protected. This plan is recommended for orchards and nurseries.

Of course every precaution should be employed in the use of these poisoned baits so that children, domestic animals, and birds may not have access to them.

Another poison which has proved efficient in the destruction of meadow mice is barium carbonate, which is very cheap and both odorless and tasteless. "This poison is usually administered in the form of a dough made of four-fifths flour or meal and onefifth barium earbonate. A little sugar is added to sweeten the mix. ture and, if desired, a couple of drops of anise oil. The dough is cut into small lumps the size of a large pea for mice........ The poison may be fed also in moistened bread or oatmeal." (Lantz, l. c. 58.)

Although meadow mice are active during practically the entire year, winter is the most favorable time for poisoning them since the supply of green food is then very limited. The mice are active on mild winter days, and are most likely to partake of the poisoned baits in the evenings of such days. Do not put out the poison on the surface of the snow for the mice usually work under it.

Coöperation among farmers in the destruction of these pests is the. most successful way of meeting the problem. By giving attention to the preventive measures suggested, much can be done in the way of food and grain conservation; and the results will amply repay those who have made the effort.

\section{PRAIRIE MEADOW MOUSE. PRAIRIE VOLE.}

\section{Microtus ochrogaster ochrogaster (Wagner).}

Hypudaeus ochrogaster Wagner, Schrebeis Säugthiere, Suppl. III, 592, 1843.

Description.-Color above mixed light and dark brown, giving a grizzled appearance; sides of body paler; feet brown with five calloused tubercles on soles; tail dark brown above, pale below, and less than one-third the length of head and body; somewhat dusky 
or blackish about the nose; color below buffy gray or pale brownish gray.

Measurements.-Total length, 6.00 inches; tail vertebræ, 1.30 inches; hind toot, 0.80 inch.

This form may be distinguished from its closest ally in our representatives of the family, the meadow mouse, by the somewhat smaller size, the grizzled upper parts, and the buffy or brownish under parts; in addition, the prairie meadow mouse has but five ealloused patches on the soles of the feet and the teats are six in number.

Habits, Distribution, Etc.-The natural habitat of the prairie meadow mouse is in dry fields and overgrown pastures of open prairie country, and hence it is very likely to destroy cultivated areas. Many native meadows, borders of corn and small grain fields, as well as cultivated clover and alfalfa fields are overrun with these animals. Wherever grasses and weeds are allowed to

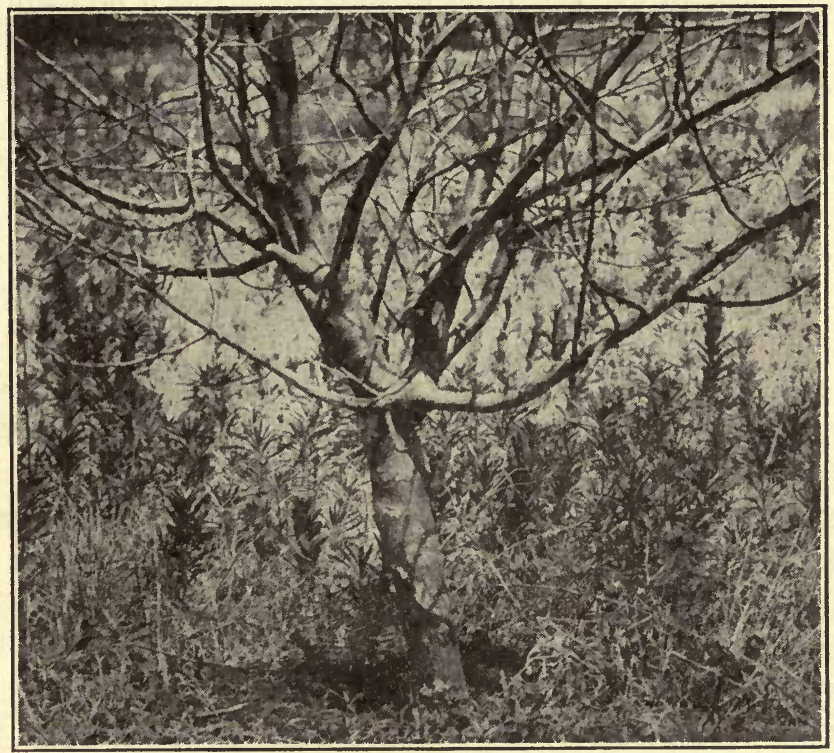

Fig. 23.-Apple tree killed by Prairie Mice. (From U. S. Department of Agriculture, Bureau of Blological Survey.)

grow and accumulate in dried matted bundles these mice are likely to be found. Pastures and neglected orchards are favored situations also, but if closely pastured the mice are driven elsewhere. If cultivated crops are not in the vicinity, their trails in some instances 
extend out for considerable distances into such pastures and orchards. Their food consists largely of roots of grasses and various cultivated small grains, and in late fall and winter they do ronsiderable damage to the roots of fruit trees and nursery stock. In this latter respect this form probably causes greater damage than does the common meadow mouse. In autumn prairie mice are often to be found under corn shocks where they cause considerable loss of grain. If cultivated crops are not to be had, these mice feed upon the roots, seeds, and leaves of various wild plants.

The nest resembles that of the meadow mouse in its construction and situation, but is somewhat smaller, while the trails and runways are constructed much as described for that species. Prairie mice seem to multiply less rapidly than meadow mice, since the number produced in a litter is usually but three or four and the long droughts of summer and continued extreme cold of winter lessen the reproductive period.

Following is an extract from Robert Kennicott's account of the habits of the prairie mouse in Illinois: "Their winter burrows on the uncultivated prairie are often in old ant-hills, or, if not, the earth thrown out of them forms little hillocks. They are not very deep, seldom over six inches or a foot, but are remarkable for the numerous and complicated chambers and side-passages of which they are composed. In one of these chambers, considerably enlarged, is placed the nest, formed of fine, dry grass. It is globular, from four to six inches in diameter, and with but a small cavity in the centre, which is entered by a very narrow opening on one side. This burrow and nest are occupied in winter, and in it at least the first litter of young is produced in the spring; but in the summer and fall these meadow-mice may be found in similar nests in grass, above ground, in which the young are often, if not usually brought forth. Nests formed under the snow in winter are also occupied by them. From the burrows, innumerable runways traverse the neighborhood, intersecting those from other burrows, thus forming a complete net-work so that often scarcely a square yard can be found in an acre not crossed by wne or more of these tracks. The runways of one pair may sometimes be traced five or ten rods on every side. These roads are not only formed for use in winter, when the ground is covered with snow, but are also employed as highways in summer. They are made above ground by pressing down and gnawing off the grass, and the earth is often 
worn quite smooth and bare in those most used. The inhabitants can travel easily along them at all times, in search of food, being well concealed by the overarching grass. In winter, these paths are formed on the ground, under the snow, as well as in the grass. The mice do not inhabit prairie pastures, where the grass is eaten close and affords them no cover." "17.

Since the food habits, economic importance, and natural enemies of the prairie meadow mouse are so nearly like those of the common meadow mouse, whatever has been said with reference to that species is, in general, applicable here and the reader is referred to that discussion for a consideration of those points. Control measures indicated for the meadow mouse are also practicable for the prairie mouse so that they need not be repeated in this place.

This mouse seems to be as widely distributed as the meadow mouse, and judging by the number of specimens received from various localities it is as abundant as or even more abundant than that species. Specimens have been received from Newton, Ottumwa, Monticel!o, Wall Lake, Waukon, Logan, Corning, Melvin, Atlantic, and Homestead. This form has also been recorded from Knoxville. See also the map on page 81 .

\section{WOODLAND VOLE.}

Microtus pinetorum nemoralis Bailey.

Microtus pinetorum nemoralis Bailey, Proc. Biol. Soc. Wash., XII, 89, 1898.

Description.- "Upper parts dull chestnut, slightly lined with blackish tipped hairs on back and rump, becoming paler on sides; belly washed with cinnamon rufous over the plumbeous underfur; tail indistinctly bicolor, agreeing with dorsal and ventral colors of body; feet thinly clothed with pale buffy or sometimes dusky hairs.

"Measurements.-Type specimen: Total length 130 [mm.]; tail vertebræ 24 ; hind foot 18 . Average of five females and five males from type locality: Total length 135 ; tail vertebræ 25 ; hind foot 18.1." (Bailey, l. c., 89-90.)

This is the largest of the so-called "pine mice;" its fur is longer and duller than in the other forms occurring to the south and east of Iowa.

Habits, Distribution, Etc.-The pine mice differ in habits from the other members of the genus Microtus, and on account of these

\footnotetext{
1857 .

17Kennicott, Robert, Agr. Rept. for 1856: U. S. Patent Office Rept., 98-99,
} 


$$
l
$$


habits are not so well known as the typical meadow mice. The woodland vole naturally inhabits wooded areas and brush land and the nearby edges of upland fields. It spends most of its lile in underground burrows built much after the fashion of those of the mole; and indeed they are sometimes mistaken for the burrows of that animal, although the internal diameter of the mole's burrow is greater. Loose, moist, and more or less sandy soil is preferred by this vole in which to construct its complicated series of burrows and tunnels. Nesting places are constructed both in the burrows and on the surface of the ground in sheltered places such as brush piles, fallen timbers, flat stones, and fences.

By means of these runways under the surface of the ground the voles invade orchards, nurseries, fields and gardens; and since the animals remain so much concealed, any injury that may have been done is not evident for some time.

In discussing the pine mouse ( $M . p$. scalopsoides), a form closely allied to the woodland vole, Lantz says: "The nurnber of young at a birth evidently averages less than is usual in the genus Mirrotus, as is shown by the small number of mammæ. Observations as to the number of litters in a season seem to be lacking, but the rate of reproduction is probably less in the pine mice than in any other American group of field mice. Blasius says concerning $M$. subterraneus of Europe, that 'it produces five or six times a year three to five young, which are blind for ten days after birth;' and this statement is probably true, with slight modifications, for all the species of the group. To compensate for slower multiplication, their liability to attack by natural enemies is much less, owing to their underground existence; so that within their range pine mice are ahout as abundant as other field mice." 18

'The food of the woodland vole consists principally of the roots of both cultivated and uncultivated plants and trees. Potatoes, sweet potatoes, beets, carrots, parsnips, and other garden vegetables, whether growing, stored in pits, or piled up in the fields are eaten by pine mice. Such damage is often attributed to moles, because of the tunnels which lead to the point of damage. However, though moles may cut off the roots of growing plants in their tunneling operations, they seldom eat the roots for they feed principally upon insects, earthworms, and other animal food.

\footnotetext{
${ }^{18 L a n t z, ~ D . ~ E ., ~ A n ~ E c o n o m i c ~ S t u d y ~ o f ~ F i e l d ~ M i c e: ~ U . ~ S . ~ D e p t . ~ A g r ., ~ B i o l . ~}$ Surv. Bull. No. 31, 20-21, 1907.
} 


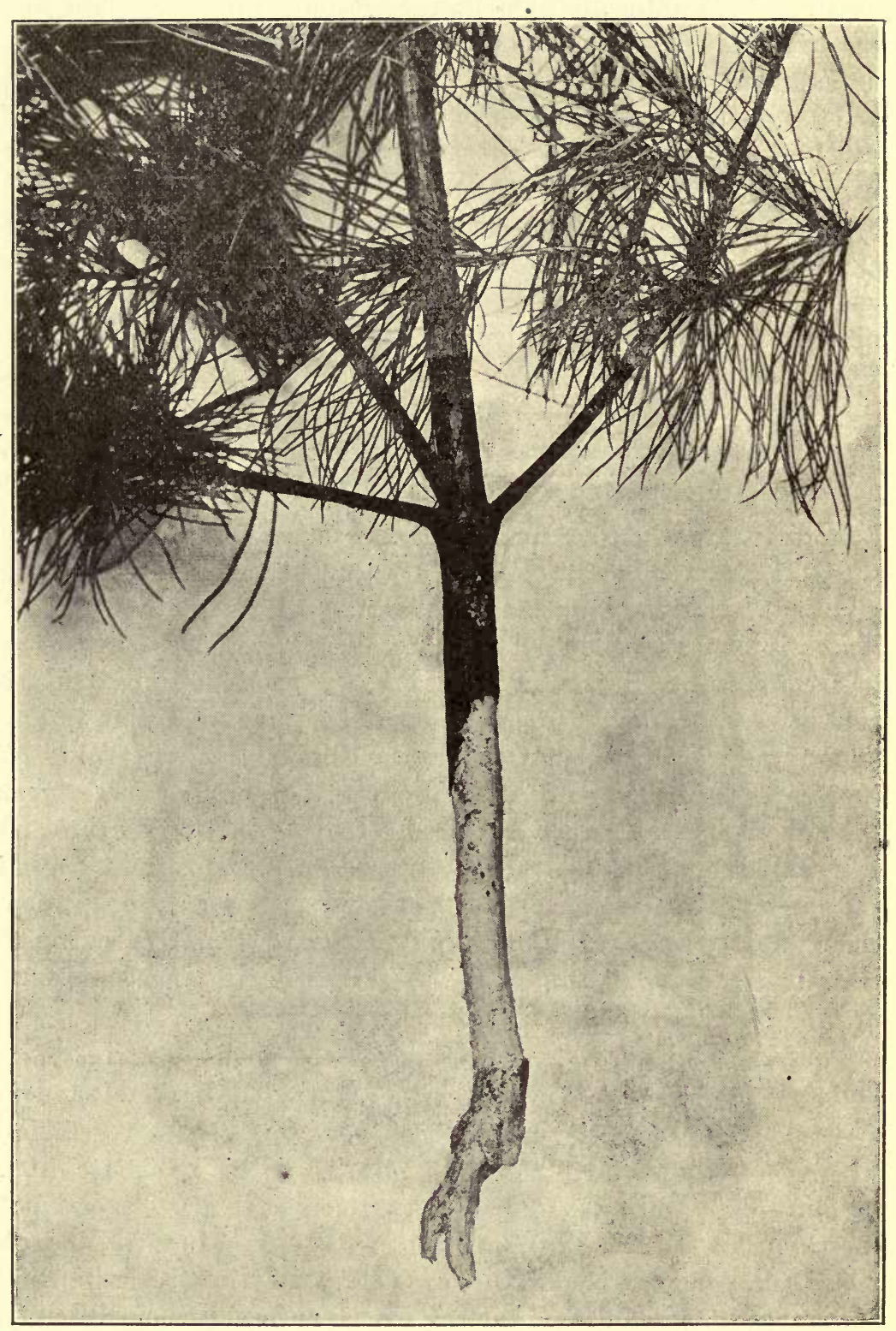

FIG. 25.-Pine tree killed by Pine Mice. (From U. S. Department of Agriculture, Bureau of Biological Survey.) 
In discussing the habits of the pine mousa in Indizna, Quick and Butler state that, "As a rule the pine mice winter in a last summer's nest which is a round ball of blue grass blades, from four to six inches in diameter; the interior is composed of fine grass which is nicely bound together with longer blades. The nest is generally placed beneath a pile of leaves or in an old stump. In winter collecting single specimens are generally observed occupying these old nests.

"The pine mouse, in winter lives upon the tender roots of young hickories, the young sprouts of the white clover (Trifolium repens), the fruit of the red haw (Crataegus coccinea L.) and the tuberous roots of the wild violet (Viola cucullata Ait.). The first of these he uses for luncheon while excavating his runways. It is never found stored in his burrows, but as his passages approach these roots they expand, laying bare a large portion of the root from which the bark is generally entirely removed. The other products we find buried, the latter in numerous deposits, some of which contain a gallon of tubers and extend eighteen inches below the surface of the ground. This latter article evidently forms the bulk of their winter food." ${ }^{19}$

So far as the writer is able to determine this is the only form of pine mouse for which authentic records from the state are at hand. The localities represented are Thayer, Ottumwa, and Iowa City. In addition, Vernon Bailey in North American Fauna, No. 17, 1900, records four specimens from Council Bluffs. See map, page 81 .

It would thus seem that this form is distributed throughout southern Iowa, Iowa City being the most northerly point in the state from which it has been taken. In states farther to the south and east of us this form is more abundant. The type locality was Stilwell (Boston Mountains), Indian Territory.

Economic Importance and Methods of Control.-While the woodland vole is apparently not sufficiently common or widely distributed in the state to be considered of major cconomic importance, both its numbers and area of distribution are likely to increase, with probable resultant damage. It is further probable that sume of the damage now attributed to the mole may be the work of this animal, owing to the fact that the latter is not generally known to the ordinary observer. Garden crops are sometimes seriously injured, both the planted seeds and the terder growing plants

\footnotetext{
${ }^{19}$ Quick, E. R., and Butler, A. W., The Habits of Some Arvicolinae: Am. Nat., $\mathrm{XIX}$, No. 2, 116, 1885 .
} 
being damaged. In addition, nurseries and orchards are often attacked and serious loss thereby sustained.

In general, the methods of control recommended for the meadow mouse will serve for the present form. Wheat, corn, oatmeal, or the seeds of sunflower, tomato or pumpkin, poisoned with the strychnia sulphate solution offer the best means of combating this vole where it has become a pest. In placing the poisoned baits it is a good plan to distribute them in the underground tunnels where the voles are most likely to find them and where the lives of birds and other animals will not be endangered.

Guillotine traps, baited or not, may be set in the underground tunnels across the runway after a place has been enlarged sufficiently to receive the trap. The opening to the outside should then be closed. This method is effective for small areas such as lawns and gardens.

It cannot be too strongly urged that clean and thorough cultivation, particularly of nurseries and orchards, the elimination of brush, dead grass and debris which offers the animals hiding places, the protection of natural enemies; and the proper and periodic rotation of crops, are all preventive measures which if properly carried out will eliminate likelihood of infestation by this vole. A high state of cultivation materially lessens danger from attack.

\section{COMMON MUSKRAT. MUSKRAT.}

\section{Fiber zibethicus zibethicus (Linnæus).}

[Castor] zibethicus Linnæus, Syst. Nat., XII ed., I, 79, 1766.

Description.-Color above dark chestnut brown, darkest on head; fur of back and rump mixed with long, blackish brown hairs; sides chestnut; feet dark brown, the claws yellowish brown; tail black, sparsely haired, compressed vertically; color below brownish white, a little lighter on throat and belly; underfur light grayish; a small spot on chin and hair of wrist and heel blackish.

Measurements.-Total length, 22.00 inches; tail vertebræ, 11.00 inches; hind foot, 3.50 inches.

Considerable variation in size and color is exbibited in this form. The worn pelage is paler and duller than is indicated in the above description; almost totally black specimens are occasionally met with; while white or partly white specimens are sometimes captured. Charles B. Cory in discussing this point says: "About three years ago Mr. W. S. McCrea of Chicago, called my 
attention to a series of seven Muskrat skins from Hayfield, Iowa, all of which were uniformly marked, having a white ring around the neck and the entire under parts, feet and terminal portion of the tail white. Such uniform coloration in a series of specimens was perplexing and suggestive especially as they all came from the same locality; but later two specimens were received from Indiana, which were similarly marked, but with the dark parts much paler. The Field Museum collection contains a pure white example of this species.",20 A specimen collected November 2, 1914, at Sabula, Iowa, and sent in to the University Taxidermist's laboratory is a uniform rusty white.

Habits, Distribution, Etc.-The muskrat or musquash, as it is sometimes called, derives its name from the peculiar musky odor which is given off by the animal. Its favorite haunts are in ponds, streams, and overflowed marshes; and it is found in practically every part of the state where such situations occur. It lives partly on land, and possesses also characters which adapt it for living in the water. The hind feet are slightly webbed, and are formed so that they may be turned edgewise when moved forward while the animal is swimming, thus affording the least possible resistance to the water. The long flattened tail acts as a rudder in swimming; the fur is long and glossy, and the underfur is very dense, thus making practically a waterproof covering.

Muskrats sometimes wander a considerable distance from water. particularly in late fall, early spring, and during severe droughts. The spring migration has been thought to be due to sexual excitement, but no definite reasons can be assigned for the movements at other times.

While muskrats are, for the most part, abroad at night, they are often seen in daytime swimming about, lying in the sun along a bank, or working on their winter houses.

Muskrat houses are composed of grasses, roots and stems of aquatic plants, rushes, weeds, etc., and the writer has seen entire houses constructed almost wholly of mud and cornstalks. Apparently the animals utilize the material closest at hand, and that which, at the same time, will serve the purpose required. These houses rest upon the bottom of the pond or stream, the domelike top composed of disarranged materials rising from one and one-

${ }^{20}$ Cory, Charles B., Mammals of Illinois and Wisconsin: Pub. Field Mus. Nat. Hist., Zool. Ser., XI, 226, 1912. 


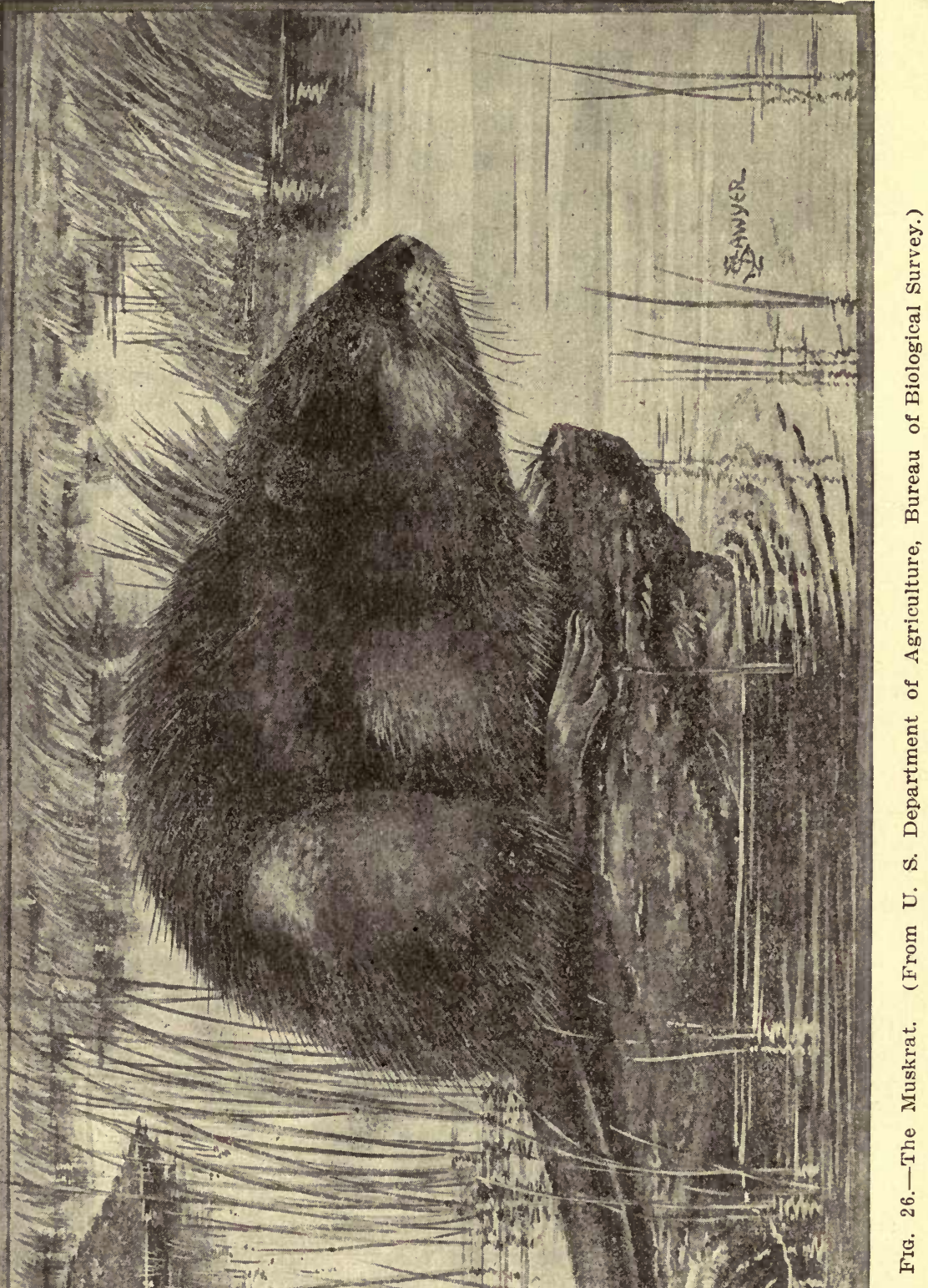


half to three feet above the water. Cory in describing one of the houses that he has seen says: "It was built in a marsh on the edge of a shallow pond; and it was constructed of reeds, weed stalks and sticks mixed with mud and was somewhat oblong in shape, although from a distance it appeared to be nearly round. The top of the rounded dome was three feet high, measured from the surface of the swamp and slightly over four feet where built up from the side under water. The greatest diameter was 6 feet. The inside chamber measured about $20 \times 17$ inches, the height above the water being about 14 inches at the highest point, the ceiling being irregular. The floor of the chamber was about 7 inches above the water but slanted downward at one side to a large hole or passageway leading out under water into the pond. The size of the houses varies considerably, however, and many are larger." (l. c., 228-229.) The writer has examined houses similarly constructed, though in many cases the materials used have been different. On March 11, 1916, the writer visited Swan lake, a body of shallow water covering between seventy and eighty acres, eleven miles northwest of Iowa City. In many places the water, was frozen to the bottom. Between twenty and thirty muskrat houses were seen, the largest being three feet high and about six feet in diameter. All were built of rushes, eornstalks, and debris of different kinds and appeared to be resting upon grass hummocks.

Such houses are used largely for shelter during the winter and also for storing places for food, but it is seldom that the young are born in them. Usually a single family occupies a house.

High banks are often taken advantage of in the construction of habitations, and in such cases the entrances to the tunnels are usually under water. The tunnels extend into the bank below the level of the water, and often are protected by roots of trees and shrubs. These tunnels are of varying lengths, and lead up to a large chamber which in many cases contains a nest composed of dry vegetation. Usually two tunnels lead from the nest to the water, and in some instances each tunnel has two branches. Burrows seem to be preferred to houses for winter habitation; but in shallow ponds and marshes houses become a necessity, and as cold weather comes on the animals add to the old winter houses, construct new ones, and deepen the channels leading to houses and burrows. The animals do not hibernate and often make little provision for winter. Julius Knepper informs the writer that on 
one occasion when the horses of a farmer broke through one of these houses on the edge of a pond near Marengo (Iowa county) at least a bushel of corn was fuund within. This may have been surplus food, which is to be found in some quantity at almost any time. When the streams and ponds are frozen over, these animals are able to obtain air in spaces under the ice and frequently air holes are to be found which are kept open through use.

Not much exact and definite information is available concerning the breeding habits of the muskrat, but the facts so far as known may be stated in the words' of Lantz: "Normally the animals mate in March and the first litter is born in April; a second litter is due in June or early July, and a third in August or September. In favorable seasons a fourth or even a fifth litter may be produced. The period of gestation is possibly no longer than twentyone days, as with the common rat and probably with the field mouse. The young are blind and naked when born but develop rapidly. Outside of low marshes, muskrats are usually born in the underground burrows." 21

The food of the muskrat consists, for the most part, of vegetable matter, but occasionally animal food is taken. In winter its staple articles of diet are the roots of aquatic plants. Carp and other mud-loving fishes as well as elams also are eaten. Robert Kennicott in speaking of the food habits of this animal says: "The muskrat is active in winter, seeking its food under the ice, and carrying it into its burrow, or house to be eaten. Though roots are sometimes found in a nest in winter, they are only such as have recently been brought in, no considerable stores of food being collected. The food, in winter, appears to consist of aquatic plants. In summer, it also feeds upon the leaves of various plants, as well as upon mussels, (Unio anodonta and $U$. plicatus, etc.), of which they consume great quantities in some of our rivers. Collecting them at the bottom it carries them in its teeth to a log or stone, where, sitting upon its haunches and grasping them in the fore-paws, it opens the shell with the incisors as skillfully as it could be done with an oyster-knife. In this way, large piles of shells are collected around stones and logs, by examining which the conchologist may often find rare species brought from the

${ }^{2}$ Lantz, D. E., The Muskrat: U. S. Dept. Agr., Farmers' Bull. No. 396, 15, 1910. 
mud by these animals which have been more successful collectors than himself.','22

While the muskrat does secure some air under the ice, in feeding it must reach the outer air. Sometimes food is eaten in the houses, which are not air-tight, while a large portion of the winter food is eaten near air holes in the ice, which, as has been said beiore, are kept open by constant use.

The summer fare of the muskrat includes greater variety and is made up of roots, stems, leaves and fruit of aquatic plants, supplemented by other fruits and vegetables from adjacent fields. Garden vegetables are in great favor and onions, cabbage, celery, carrots, parsnips, beets, peas, etc., are subject to attack with considerable resultant damage. At Chariton, Adel, and Marengo damage is reported to have been done to green corn, especially in fields bordering streams. In addition to the mollusks above referred to, muskrats occasionally feed on the bodies of dead wild birds, and have been known to attack wounded or trapped individuals of their own kind. It is said that when food is scarce they will kill and eat members of their own community.

The food collected by the muskrat in summer is usually eaten at the edge of the water, in many instances while the captor is sitting on the end of a log, or on a pile of driftwood.

The muskrat is distributed over most of the state, though during the past four or five 'years the numbers have been steadily on the decrease owing to the extensive trapping and to the draining of marshes and ponds. In Kossuth, Carroll, Hardin, Calhoun, Emmett, Winnebago, and other counties of the state in which considerable areas have been drained, the number of these animals has been materially reduced. In both Emmett and Palo Alto counties more than one hundred county drainage ditches have been constructed within the past few years. This extensive system of drainage has driven out the muskrats but of course many thousands of acres of exceedingly fertile land have been opened to cultivation. Outside of the counties above mentioned, considerable numbers of the animals have been reported from Dickinson, Franklin, Lucas, Dallas, Iowa, and Dubuque counties. Bergman Island, in the Mississippi river near MeGregor, supports many houses of the muskrat. M. X. Geske of McGregor informs the writer that in the spring of 1914 he counted forty-two houses in one slough

${ }^{22}$ Kennicott, Robert, Illinois Agr. Rept. for 1856: U. S. Patent Office Rept., $106,1857$. 
near that place. Muskrat houses are also much in evidence in the vicinity of Spirit Lake and Estherville. Numerous other ponds and marshes over the state furnish their quota, but trappers and collectors everywhere state that the number of these animals has decreased markedly in the past four or five years.

Economic Importance.-In an economic way the use of muskrat fur is of greatest importance. As compared with other furs of small size muskrats furs are dense, soft, and at the same time possess excellent wear-resisting qualities. The furriers have worked out methods of imitating many of the more costly furs with that of the muskrat, and thus a constant demand for the latter is created. C. Freedman, furrier at the Edes Robe Tanning Company of Dubuque, informs the writer that of the smaller mammal skins that come to the tannery muskrat skins head the list so far as numbers are concerned. J. A. Spurrell of Wall Lake writes that, "Muskrats were the most important, [fur-bearing animals] because the most abundant. The skins were worth from eight to ten cents each in 1857 and from 12 to 15 cents each in 1870, when Shelt Tiberghien and two partners trapped 6250 muskrats from October, 1870, to May, 1871. The muskrats were called the 'savior of the people', and taxes were paid from the proceeds of trapping

Muskrat fur first came into demand through its use in the making of imitation beaver hats. Later, silk and wool having replaced the beaver, muskrat skins came to be used as an imitation of sealskin; and if properly made up they are, indeed, difficult to tell from the real article, although the wearing qualities are much inferior.

In regard to the trade in muskrat furs Lantz says: "The growth of the demand for muskrat furs is shown by the records of London importations and sales. From 1763 to 1800 (thirty-eight years) the total number of skins imported and sold in that market was $2,831,453$, an average of less than 75,000 yearly. During the fifty years from 1801 to 1850 the total was $20,571,428$, or an average of 411,000 yearly. From 1851 to 1890 , inclusive, the importations were $99,893,591$, a yearly average of $2,500,000$. The average London sales in recent years have been cyer $4,000,000$ per annum, and the entire output of skins for 1900 was 5,285,000. A large part of the total collection is sold through London, but in the last few years an increasing number are dresser and manufactured in America.

Notwithstanding that during the past century and a half nearly a quarter billion of muskrats have been trapped, the supply has not 
greatly diminished. The total output of 1905 , as indicated by London sales of $5,000,000$ skins in 1906 , was over $7,000,000$. The sale of these was accompanied by an advance of 40 per cent in prices. The sales for 1907 showed a further advance of about 25 per cent, but a falling off in the offerings of fully 1,500,000 skins. The London sales for 1908 and 1909 showed still further rise in prices, which were again advanced in the January and March sales of 1910.', (l. c., 24-26.)

The flesh of the muskrat has been used widely as food, particularly by the Indians and by professional hunters and trappers; while of recent years persons of refined tastes have eaten the flesh, although with considerable diversity of opinion as to its flavor. The flesh is fine-grained and dark red in color; but skill and care are required in skinning the animal that the hair does not come in contact with the flesh, and that the musk glands come away from the flesh without tearing. The following recipe for cooking muskrat is copied from Forest and Stream: "Soak the carcass over night in cold water or let it freeze in the open air. Cut in pieces ready to serve and place in a pot with a few slices of salt pork. Add water enough nearly to cover the meat and stew slowly until about dry - say, for an hour and a half. Pepper and salt to taste while cooking.' (1898, 368.) The musky odor permeates the flesh in summer, at which season it would scarcely be fit for food.

Muskrats are easily trapped and in winter and early spring readily take such baits as carrots, sweet apples, parsnips, and turnips. Usually the ordinary No. 1 steel trap is used. Sometimes the trap is sunk in the trail and embedded partly in the mud and sand in shallow water. At other times it is set at the opening of the burrow into a bank, in whick case bait is not required. Local conditions and the ingenuity of the trapper play a considerable nart in successful trapping. Various methods and details of trapping may be found in Farmers' Bulletin No. 396 of the U. S. Department of Agriculture.

While the muskrat does cause some damages in a few places, its destructive qualities in this state are scarcely sufficient to warrant drastic control measures. In not many places in Iowa are dams or dikes employed to hold back large quantities of water, while in marshy localities the good which the animals do outweighs the damage. Practically the only incentive to trapping is the value of the skins; and since their value has, of late years, increased ma- 
terially, the number of animals may before long be reduced to a point where the species is in danger of extermination.

The natural enemies, of the muskrat include the mink, and the larger hawks and owls. Of course floods, droughts and very severe winters take their toll of muskrat lives, but trapping and the reclamation of swamps and marsh lands are mainly responsible for the great reduction in numbers. The drainage of swamp land is being carried out extensively in many parts of Iowa, and if a supply of fur is to be maintained protective laws and private ownership must seek to maintain the proper equilibrium. Of course it cannot be denied that the land thus reclaimed is exceedingly valuable from an agricultural standpoint, but farmers and owners of land on which suitable muskrat habitats are found should take a part in the protection of this fur-bearer and see that a few places are reserved for its use.

In Iowa, the muskrat is protected from April 1 to November 1, except when found damaging private or public property. It is entirely proper that legal enactment should forbid the destruction of these animals, especially during the season of reproduction which the above time is designed to cover. Every one should see that this law is strictly enforced. Spearing, shooting, and the destruction of houses should not be tolerated in any community where the animals are not sufficiently numerous to do material damage; and if they are properly protected they will furnish a constant source of fur for many years.

Where muskrats are exceedingly abundant, especially in the vicinity of eanals, drainage ditches and embarkments of streams, methods of control are sometimes required. Trapping is effective in both summer and winter, but is a slow process. Shooting is effective for a short time, although a continuation of the practice causes the animals to become exceedingly wary. Poisoning is an effective method of destroying them. Powdered strychnia sulphate mixed with a little powdered sugar and sprinkled over freshly cut pieces of carrot or apple, has been used with considerable success. Sometimes good results can be obtained by inserting crystals of the strychnia sulphate into baits of apple or carrot. Great care must be observed in keeping the baits where poultry or live stock will not reach them.

When any. such protective measures as above suggested are employed, it is well to confine them to the time when the fur is at its 
best. In this way something is realized in the way of protection, and at the same time, the skin is thrown upon the market.

Various means of protecting property from damage by muskrats have met with considerable success, and a few of these may be mentioned here.

In the construction of dams and bridges the use of concrete foundations will entirely obviate any likelihood of damage from muskrats, besides rendering the structures safe from other danger for many years.

The use of sand or coarse gravel on the surface of embankments for artificial ponds and the like will prevent muskrats from burrowing, since the sand and gravel fill in the hole as rapidly as it is opened.

Gardens and truck patehes may be protected from muskrats by erecting a galvanized wire fence at least three feet in height and of one and one-half inch mesh entirely around the plot or at least on the side bordering the stream or pond. The lower edge of the fence should be set down into the earth at least six inches in order to prevent the animals from digging beneath it.

\section{GREAT PLAINS MUSKRAT.}

Fiber zibethicus cinnamominus Hollister.

Fiber zibethicus cinnamominus Hollister, Proc. Biol. Soc. Wash., XXIII, 125, September 2, 1910.

Description.-"Fresh pelage: Upper parts and sides cinnamon brown, dorsal areas only slightly darker, with few black hairs. Nose to forehead and eyes seal brown. Cheeks and underparts creamy clay color, lighter on neck, throat, and inner sides of legs. A very small brown spot on chin. Feet drab; iails yellowish. Tail dark brown. Worn pelage: Varying from wood brown to russet, depending upon the state of wear or renewal. Specimens in the short-haired early fall pelage are the darkest, and those in extreme faded or washed out early summer coat are the lightest." ${ }_{23}$

Measurements.-Total length, 19.00 inches; tail vertebræ, 9.20 inches; hind foot, 2.80 inches.

This form averages smaller than the common muskrat, and the teeth are smaller than in that form. Also paler, the coloration is with considerable red or reddish in the pelage. With these ex-

\footnotetext{
${ }^{23}$ Hollister, N., A Systematic Synopsis of the Muskrats: N. A. Fauna, No. 32, 20, 1911 .
} 
ceptions the great plains muskrat closely resembles the common muskrat; but its distribution is more to the westward. Hollister (l. c.), gives the geographical distribution of the present form as follows: "Great central plains region of western United States and Canada; from Manitoba south to northern Texas; east to central Iowa and west to the Rocky Mountains.'. A single individual is recorded from Knoxville, Iowa. The writer has not obtained specimens of this muskrat, but collectors and trappers should be on the lookout for it in western Iowa where the area of intergradation occurs. It is found in the sloughs and streams of the interior plains region, and its habits are practically the same as those of the common muskrat.

\section{GOSS' LEMMING MOUSE.}

\section{Synaptomys cooperi gossii (Merriam).}

Synaptomys helaletes gossii Merriam, Proc. Biol. Soc. Wash., X, 60, 1896.

Description.-Summer: General color above rusty brown or reddish brown, with which are intermingled black-tipped hairs; a blackish mark at base of whiskers; tail short, brownish above, pale below; color below slaty gray, the hairs tipped with white but the gray showing through. Winter: Grayer and with less reddish brown. The young are slaty or grayish brown above, the color varying with the age.

Measurements.-Total length, 5.00 inches; tail vertebræ, 0.70 inch; hind foot, 0.75 inch.

Some little variation in size and color obtains in this form, which, in our fauna probably most nearly resembles Dyche's harvest mouse. However, it may be distinguished from that species by the much shorter tail, the absence of a distinct line along the middle of the back, and the fact that the upper incisors (front teeth) have the longitudinal groove on the anterior face much narrower and near the outer edge. The crowns of the molars (cheek teeth) have transverse loops. These two mice are our only representatives of the family which have grooved upper incisors, though the extent of the groove in the two forms differs markedly and in other respests they are rather widely separated.

Habits, Distribution, Etc.-This is one of our smallest mice and appears to inhabit grassy fields and hillsides and open places 
in the woods. A. H. Howell of the United States Biological Survey has reported this form present in considerable numbers at Horseshoe Lake, St. Charles county, Missouri, towards the latter part of April. Concerning this observation he reports as follows: "A large colony had occupied a low marshy meadow close to the Mississippi River. At the time of my visit the water in the river was very high, and the meadow was overflowed to a depth of 12 to 18 inches. The mice had been driven from their burrows by the high water, and were hiding as well as they could on tussocks and under patches of floating debris. When disturbed they ran rather freely over the submerged vegetation and swam freely, but they were easily overtaken. Many had been killed by dogs or other predatory animals, and I was able to get as many specimens as I needed by catching them in my hands. The burrows in this meadow were on the little hillocks, the entrances near the top. Thus they are probably dry except in times of very high water.

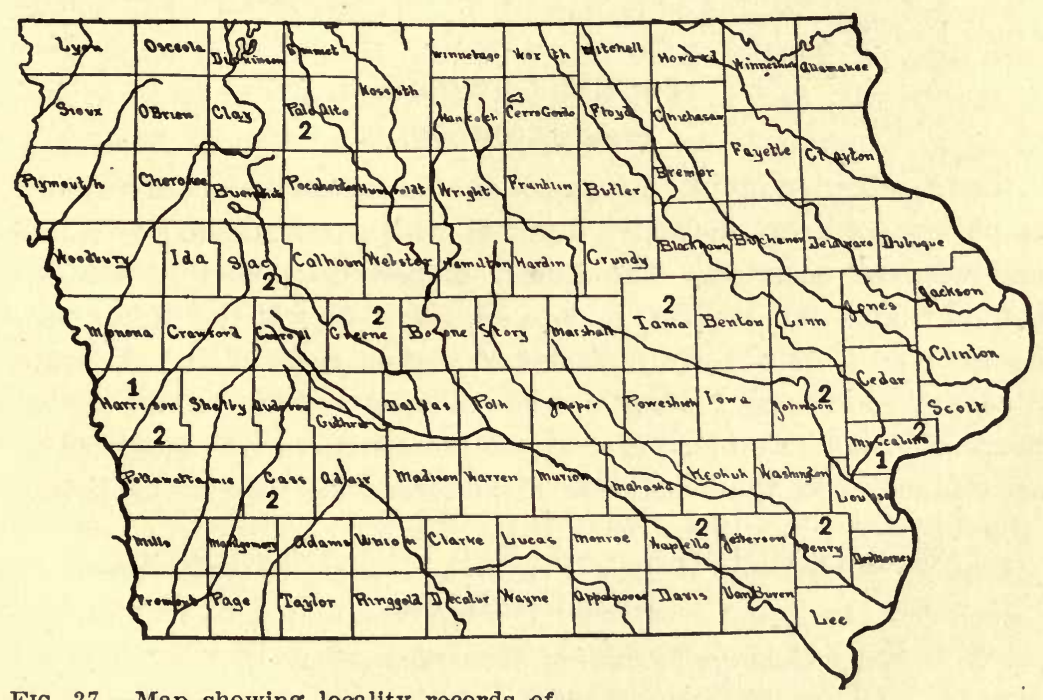

FIG. 27.-Map showing locality records of-

1. Goss' Lemming Mouse (Synaptomys cooperi gossii).

2. Prairie Harvest Mouse (Reithrodontomys megalotis dychei).

The entrances are perfectly oper and not concealed under vegetation as is the habit of Synaptomys cooperi in the eastern states. Well-beaten runways extended out from the burrows and under the dead vegetation." 24

${ }^{24}$ Howell, A. H., Mammals of the Middle Mississippi Valley: Proc. Biol. Soc. Wash., XXIII, 30, 1910. 
The geographical distribution of several of the closely allied forms of the genus Synaptomys has not yet been definitely worked out, so that some of the reports which have been made concerning the habits of one form may properly be credited to what may prove to be another. This is probably the form recorded by Osborn (Proc. Ia. Acad. Sci., 43, 1887-1889) and in, "A Partial Catalogue of the Animals of Iowa," (Ames, Iowa, 5, 1891), but in neither case are definite localities given. T. Van Hyning, (Proc. Ia. Acad. Sci., XX, 311, 1913), recorded this form from Fairport, the record being taken from a single specimen secured by T. Surber of the U. S. Biological Station, February 16, 1912, on the laboratory grounds. This mouse has also been recorded from Knoxville. In the course of this work but one specimen has been received and that from Logan, Harrison county, at the extreme western border of the state. Thus, although the recorded specimens have been taken at widely separated points in the state, the probability is that Goss's lemming mouse may be found sparingly in practically every locality.

\section{POGKET GOPHERS.}

\section{Family GEOMYIDA.}

The family Geomyidæ comprises the mammals commonly known as pocket gophers; the distribution of which is restricted to North and Central America. The family is best developed in western. United States and Mexico; it does not occur east of the Mississippi Basin except in the Gulf States where it reaches the Atlantic States in Florida and Georgia. The members of the family are all fossorial and live under ground and their structure is modified in accordance with the needs for a subterranean method of living.

\section{POCKET GOPHER. SHA.W'S POCKET GOPHER.} RED GOPHER.

\section{Geomys bursarius bursarius (Shaw).}

Mus bursarius Shaw, Trans. Linn. Soc. Lond., V, 227, 1800.

Description.-Upper parts chestnut brown with the concealed bases of the hairs dark plumbeous; under parts paler; feet whitish; tail stout, the basal portion with hairs chestnut brown, the apical portion sparsely covered with white or whitish hairs; body heavy, neck very short; fur-lined cheek pouches opening to the exterior; front feet enlarged, fitted for digging, the claws usually large and long. 
Measurements.-Total length, 11.00 inches; tail vertebræ, 3.25 inches; hind foot, 1.50 inches.

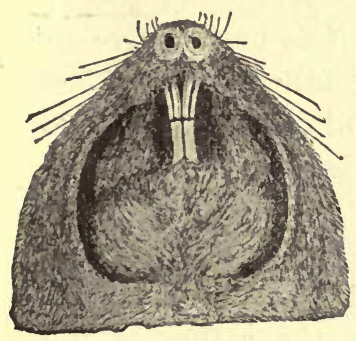

$x$

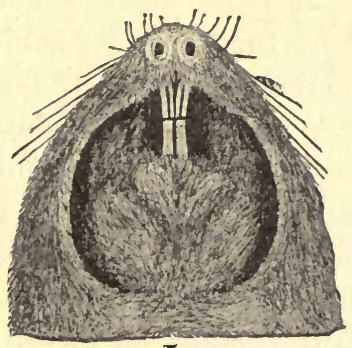

6

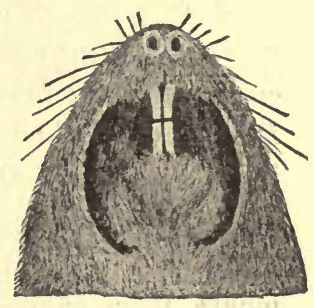

c

FIG. 28.-Faces of Pocket Gophers, showing pouches and incisors. (From U. S. Department of Agriculture.)

The pocket gopher shows but little tendeney to variation in color according to season, but the variation in size, due principally to difference in sex, is quite pronounced. The females are always smaller than the males, the discrepancy in this species being as much as an inch in total length, a half inch in length of tail and from three to five millimeters in length of hind foot. In addition, differences in cranial characters, aside from the matter of size; are apparent in the two sexes; the female usually has a broader and flatter brain case, the zygomatic arches are narrower, the rostrum and nasals shorter, and the entire skull smoother than is characteristic of the male.

Habits, Distribution, Etc.-The pocket gopher is of more economic importance than all of the other species of the family together and in Iowa at least is of greater consequense economically than all our other species of rodents combined. Iowa is fortunate in that she is furnished with a great deal of exceedingly fertile land, but unfortunate in that this rodent pest is apparently most at home in just such rich and densely populated cultivated territory. A very conservative estimate indicates that the annual loss to agricultural interests in the state of Iowa due to depredation by the pocket gopher amounts to a half million dollars. This is a sum which is worthy of consideration and which could be materially reduced by proper and uniform control measures, which will be discussed below.

The pocket gopher lives almost entirely in underground tunnels which it excavates in loose alluvial soils rather than in those which are hard or clayey. Sandy soils are seldom worked, since burrows can not be successfully constructed in such loose material; as a 
result sandy regions are not much troubled with this pest, and the sandy sections of the state which have been visited report few of the animals and little damage done. While the pocket gopher is not strictly nocturnal in its habits, it is most active in early morning and evening; however, if temperature and weather conditions are favorable it may work all day and on into the night. Hot, dry weather affords little incentive for digging. In working its way through the earth the animal uses the powerful upper incisors in loosening the soil, while the front feet are also used in digging and in pushing the earth backward beneath the body where it is carried still further backward by the action of the hind feet. After a quantity of earth has accumulated behind the burrower he turns around in the tunnel, places the palms of the front feet vertically beneath the ehin and pushes himself and the earth along with his hind feet. On arriving at the opening of the tunnel he forces the earth out to form the so-called gopher "hill."

The writer has seen such mounds of earth six to eight feet in diameter and a foot or more in height. It is said that on wild prairie land the pocket gopher frequently throws up mounds larger than this. The great number of fresh mounds that may appear in a restricted locality during the course of twenty-four hours, indicates that considerable distances are traversed.

The burrows are usually about two feet beneath the surface and often are quite complicated, forming a kind of network of subterranean roads. At intervals of a few feet shafts are run to the surface for the conveyance of the earth that has been removed in the construction of the tunnel. It has been estimated that the burrows of a single animal from one season's burrowing, if straightened out, would measure a mile in length. In one of the larger mounds the gopher has its nest where it hoards a supply of food and rears its young. "Apparently pocket gophers breed but once a year, usually early in the spring and they produce from two to six young in a litter. T. H. Scheffer, of the Kansas State Agricultural College, trapped thirty-four pregnant females from January 31 to May 13 . The smallest number of embryos found was 1 ; the largest 6 ; the average 4.2. While gophers are less prolific than many other rodents, the seclusion in which they live compensates in great measure for their lack of fecundity, since their enemies have relatively few opportunities to secure them. Except in 
the mating season and when the female is caring for her young, gophers seem to live alone." 25

Frank C. Pellett of Atlantic has in his collection a young female pocket gopher taken from the nest of a red-tailed hawk May 18, 1916. The measurements are as follows: Total length, 6.50 inches; tail vertebræ, 1.80 inches; hind foot, 0.90 inch.

Pocket gophers have a tendency to roam about somewhat, particularly in late summer and fall, and at these times numbers of new mounds are often found in fields some distance away from the regularly inhabited areas. Even in late autumn and during the winter the animals, especially the males, wander about more or less. On October 13, 1913, a live specimen was brought to the office of the writer by $\mathrm{A}$. O. Thomas. He had found it running about on the surface of the ground evidently in migration. This specimen was kept confined in a wire cage in the office for several days. It appeared to dislike the light and embraced every opportunity to escape from it. Apples, potatoes, and the roots and green stalks of dandelions were fed the animal. . It seemed especially fond of the green dandelions; and holding a stalk in its front claws would begin at one end and not stop until the entire stalk was eaten, when it would be ready for another. The animal took water from a pipette at times rather greedily and with much relish.

Charles Miller, living near Decorah, reports having taken pocket gophers alive in winter from under the snow. The animals had probably worked out of their burrows and were unable to find their way back again.

Pocket gophers do not hibernate in the true sense of the word, but lay up enormous stores for the winter, some of which they place only a little distance beneath the surface of the earth so that they are overturned by the plow. Other and more extensive stores are placed deeper in the soil. The various roots upon which the animal feeds are cut in short pieces, packed into the great cheek pouches, and carried away to these caches which usually contain much more food than the animal can possibly eat. This great destruction of food materials adds to the extensive damage done by these animals.

The pocket gopher occurs throughout the state, but is rather more abundant in the central, northcentral, and eastern countics,

${ }^{25}$ Lantz, D. E., Pocket Gophers as Enemies of Trees: Yearbook, U. S. Dept. Agr., 210, 1909. 
where of course it does most damage. However, not a single county is blessed by the entire absence of the pest; and, if anything, its numbers seem to be on the increase in spite of the rather sporadic efforts made toward its control. In addition to cultivated fields, the rights of way of railroads form one of the most generally infested areas in most parts of the state.

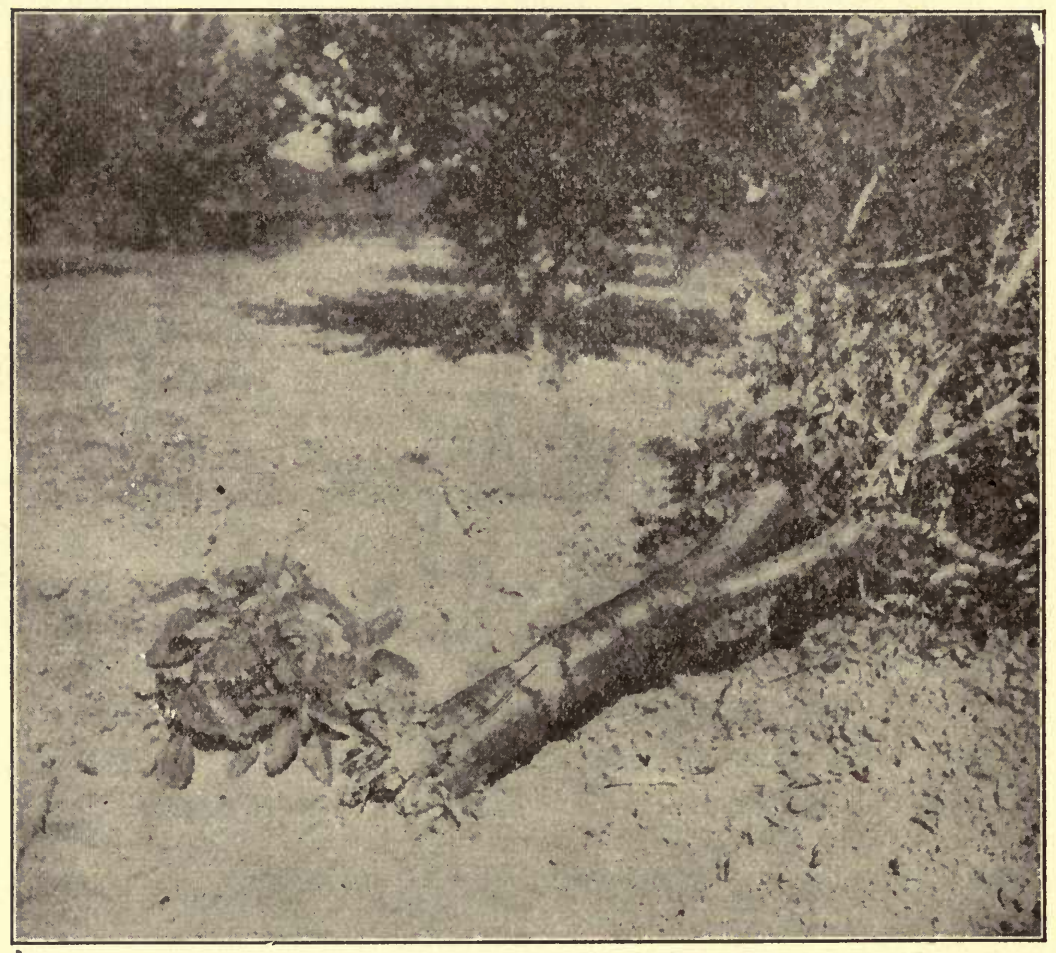

FIG. 29.-Apricot tree killed by Pocket Gopher. (From U. S. Department of Agriculture.)

Food Habits, Economic Importance, and Control Measures.-The food of the pocket gopher consists, for the most part, of the roots of various plants, which are usually attacked from below, and without the animal's issuing from the burrow. In early days it fed on the roots and stems of native plants, but upon the introduction of eultivated plants by the settlers, it immediately turned its attention to them, in many cases with disastrous results. In addition, with the settling of the country, numbers of the natural enemies of the gophers were destroyed and the soil more or less 
loosened by cultivation, so that the living conditions of the animal were improved rather than harmed. As a result, in many places where strict and coöperative methods of control have not been in vogue, the animals have increased in numbers and extended their range.

Among the cultivated plants most attacked by these pests are clover, alfalfa, timothy, potatoes, and garden vegetables, in addition to fruit and other trees; while of the uneultivated plants the roots of wild sunflower, spike-flower, rosin-weed, and other weeds form the main items.

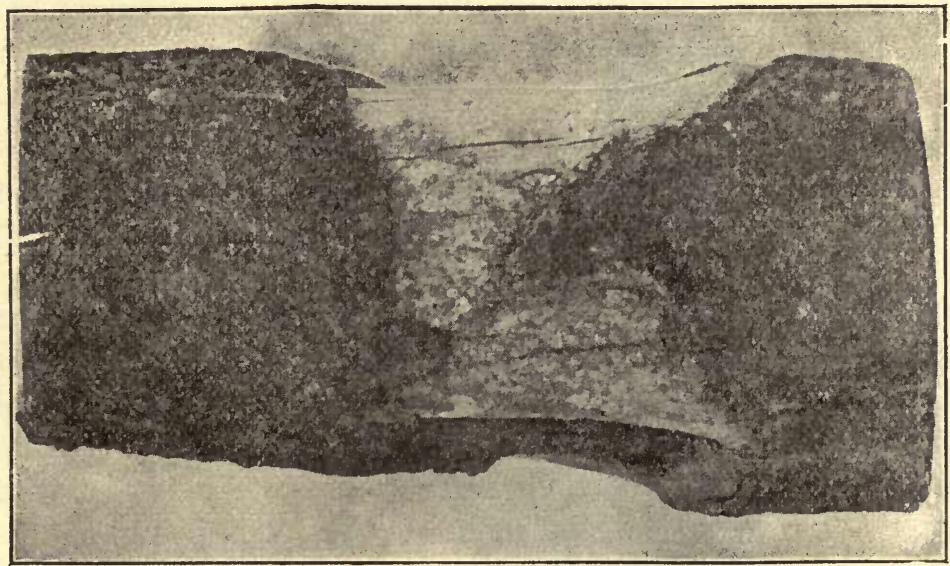

FrG. 30.-A section of the Apricot tree shown in the preceding view. The injury was under ground. (From U. S. Department of Agriculture.)

Besides this, gophers do much harm in other ways; they cover hay lands with earth, thereby preventing close mowing; the burrows allow the entrance of surface water, and on hilly ground these form the beginnings of gullies; and burrows in dams often cause serious breaks. In fields of small grain and corn in the shock, they sometimes do a good deal of damage by throwing up mounds of earth under the shocks, thereby burying considerable grain.

One reason that may be advanced for the extreme destructiveness of pocket gophers is the fact that since they work beneath the surface their ravages may remain unseen for some time and considerable damage be done before suitable control measures are thought to be necessary. 
While gophers seldom inhabit forests and hence cause little injury to forest trees, they do cause considerable damage to orchards. and nursery stock, apparently not exercising much choice in the kind of trees attacked but feeding indiscriminately on their roots. The animals take not only the bark but the entire root, such roots if particularly relished being entirely eaten leaving the trunk loose in the earth. At Clarion, F. E. Osier reports that pocket gophers had gnawed the roots of some of the pine trees in the cemetery there so that the trees leaned very noticeably to one side. The nursery stock in the Welch Nursery at Shenandoah also has been damaged in this way.

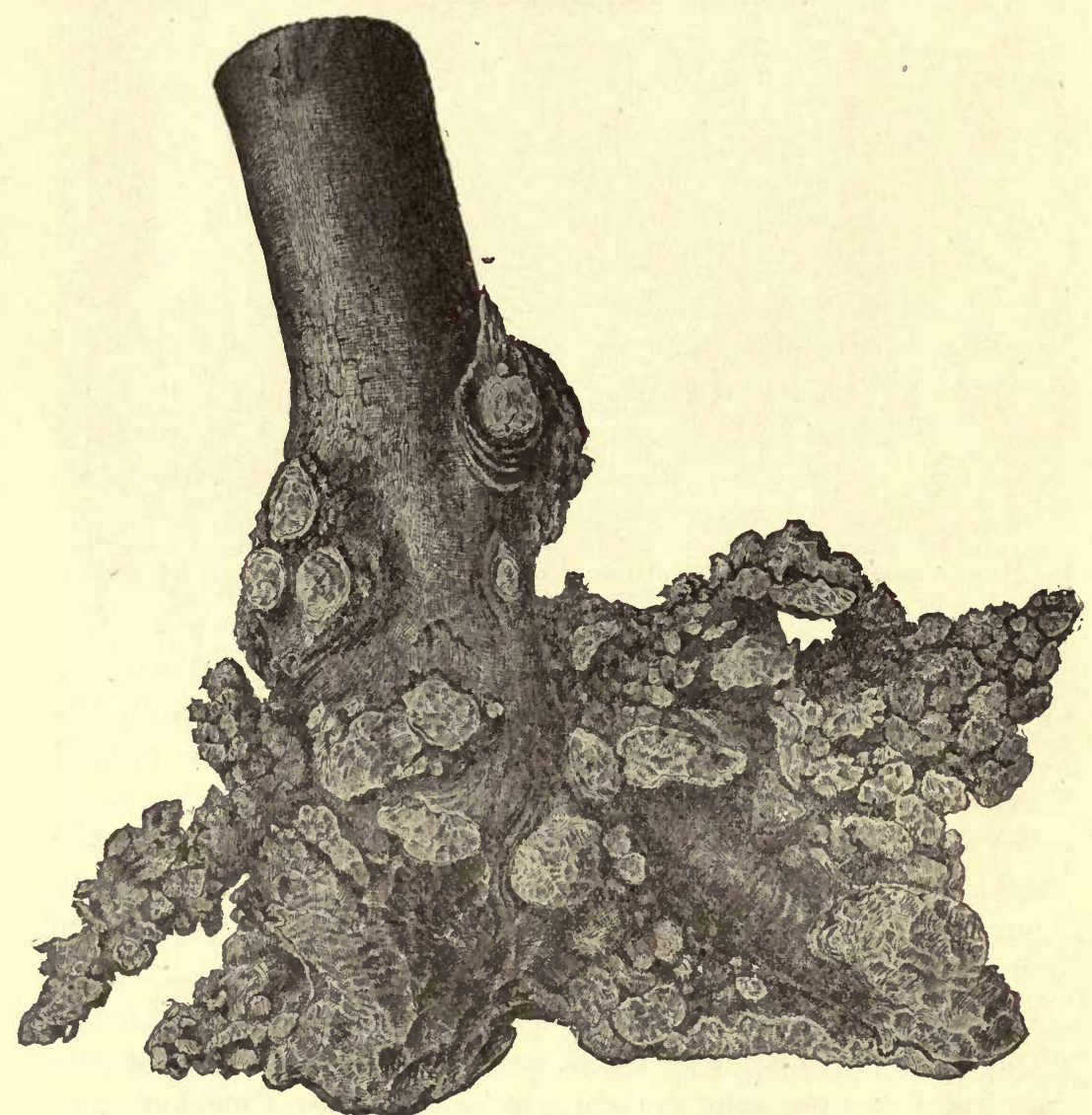

FIG. 31.-Root of Apple tree gnawed by Pocket Gopher. Root knots prominent. (From U. S. Department of Agriculture.)

Of course the gopher, in spite of its fossorial and semi-diurnal habits, has many natural enemies which assist in holding its num- 
bers in check. Practically all our larger hawks and owls, particularly the barn owl, capture numbers of these rodents outside of the burrows. Badgers, weasels, and skunks also lay claim to a share in destroying the pests, skunks and weasels being particularly effective. J. P. Kingsley of Dubuque reports that in that locality skunks kill many of the gophers. Of the snakes the bull snake and hog-nosed snake are of first importance. The snakes and weasels are of special value in that they are able to enter and traverse the gophers' burrows. It should be unnecessary to state that all of the above-mentioned enemies of the pocket gopher should be protected and not needlessly or thoughtlessly killed as is so often the ease. A moment's reflection before striking down one of these allies of the agriculturist will be productive of much good.

In the artificial control of any rodent pest, little of permanent value can be accomplished without mutual coöperation. If a farmer or nurseryman or fruit-grower in a given locality destroys the pocket gophers on his own land without others of the community coöperating in the warfare, his efforts will avail little and his land will be in constant ranger of being reinfested from neighboring farms. It cannot be too strongly emphasized here that united effort on the part of the individuals of a township or county is the only safe and satisfactory way in which to secure thorough and permanent immunity from these pests.

That enormous damage is sustained from the ravages of pocket gophers has long been recognized, and in the attempt to control the increase and spread of the animals bounties have been offered in our own state as well as in many others.

Section 2348 of the Supplement to the Code (1907) as amended by the thirty-fourth General Assembly (1911) relating to the payment of bounties on pocket gophers provides a uniform, statewide bounty of ten cents each and reads as follows:

"Sec. 2348. Bounties.

Sec. 2348-a. Amount of Bounty. There shall be paid from the general fund of the county a bounty of ten cents for each pocket gopher caught and killed within the county, provided that the person entitled to such bounty shall make, as hereinafter provided, proof of the destruction of such animal within thirty days after the same was destroyed. 
Sec. 2348-b. Proofs required. The person eatching and killing any such animal shall remove and present to the officers, before whom he makes his proof, both front feet and claws of each animal for which he claims the bounty, and the person claiming the bounty shall furnish written proof, under oath, that each animal for which he claims the bounty was caught and killed in the county against which he presents the claim for bounty, and the board of supervisors may require in addition to the above any other and further proof which it deems necessary and reasonable to show that each animal for which the bounty is claimed was caught and killed within the county against which the claim is presented.

Sec. 2348-c. To whom presented. The claws and other proofs 1 equired may be presented to the county auditor; and the board of supervisors of each county may appoint registrars or other off:cers in other parts of the county to whom claws of the animal caught and other proofs of the killing may be presented."

However, as has been indicated before in this paper, the bounty system as a means of reducing the number of rodent pests is not only unsatisfactory but very expensive. At best, a bounty is but a temporary expedient for checking the increase of the animals, and even if it is made sufficiently large to materially reduce their numbers in a given locality the time soon comes when it becomes no longer profitable to secure the animals for bounty. Seldom, if ever, is a bounty effective in exterminating a noxious animal. With such an animal as the pocket gopher at least, hope of extermination by offering bounty is entirely out of the question. Under present conditions it does serve in a measure, to keep down the numbers of the pests even if extraordinary expense is involved. If, on the other hand, coöperative effort towards control measures could be secured along some of the lines that will presently be suggested, vastly better results could much more economically be secured, so that the funds now expended in this attempted control might be diverted into more fruitful channels. North Dałota, California, and other states have successfully carried out this plan and with excellent results.

Under the bounty system, as at present carried out, various methods of payment by the auditors of different counties are employed, while also the evidence required is somewhat at variance according to the interest taken by the county officials. In two of the sixty-two counties visited the people vere virtually given 
to understand by those in authority that a bounty was not paid on the pocket gopher. In some cases it was found that the full amount of bounty was paid for a single front foot. In other places justices of the peace and officers called registrars are entrusted with the payment of bounties, these officers making their reports to the county auditor. Some of the registrars are charged with dishonesty in the payment of such bounties. In Muscatine county the board of supervisors decided, in 1911, that the payment of bounties involved an unnecessary drain upon the county funds; and accordingly the bounty was removed from all animals upon which it had been paid and upon which it might be paid except wolves, and this in spite of the enactment of the General Assembly.

In the course of the preparation of this paper an attempt was made to ascertain the amounts paid out in bounty for pocket gophers in the various counties visited. In all, data from sixtytwo counties of the state have been obtained; and while the results are not entirely satisfactory, they will give a general idea of the large amounts expended for the destruction of these pests. The year 1913 has been chosen simply at random and not with special reference to any particular point, save that that year seemed to indicate a fair general average as regards all items concerned. As a basis for comparison the bounties paid out in the year 1915 in the same counties are added.

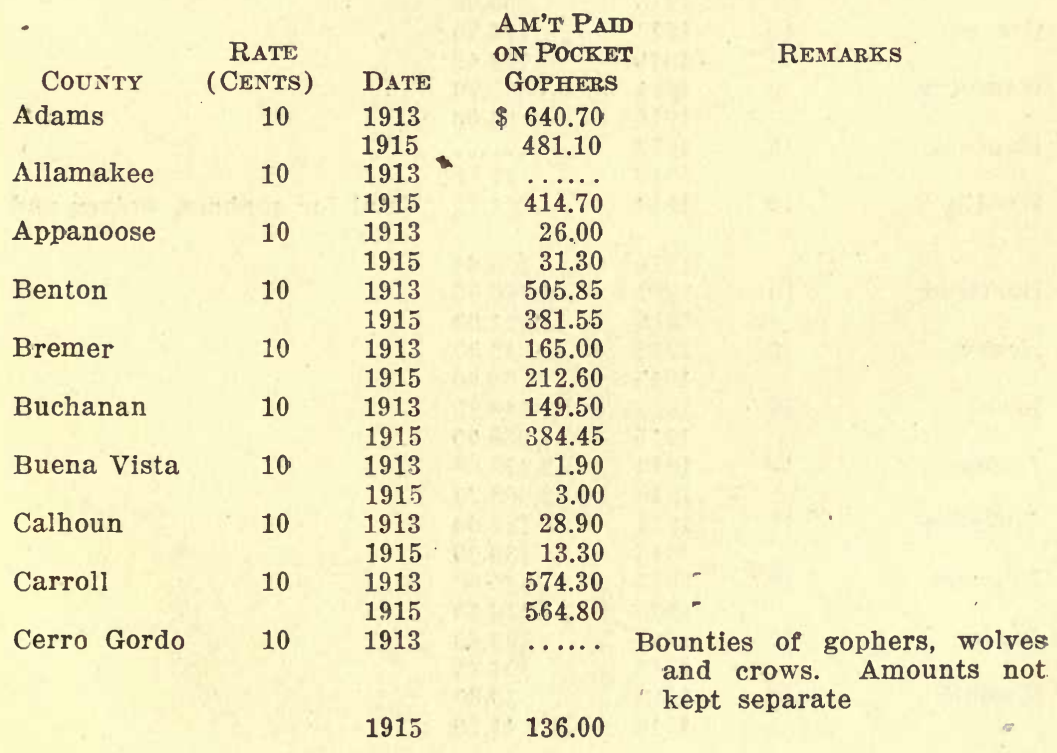




\begin{tabular}{|c|c|c|c|c|}
\hline County & $\begin{array}{c}\text { RATE } \\
\text { (CENTS) }\end{array}$ & Date & $\begin{array}{l}\text { AM'T PAID } \\
\text { ON POCKET } \\
\text { GOPHERS }\end{array}$ & REMARKS \\
\hline Cherokee & 10 & $\begin{array}{l}1913 \\
1915\end{array}$ & $\begin{array}{r}55.00 \\
108.90\end{array}$ & \\
\hline Chickasaw & . & 1913 & ...... & Bounty discontinued in 1910 \\
\hline Clarke & 10 & $\begin{array}{l}1915 \\
1913 \\
1915\end{array}$ & $\begin{array}{r}\dddot{87.45} \\
239.55\end{array}$ & s. \\
\hline Clay & 10 & $\begin{array}{l}1913 \\
1915\end{array}$ & $\begin{array}{r}5.25 \\
.70\end{array}$ & * \\
\hline Clayton & 10 & $\ddot{19 \dot{15}}$ & 463.... & \\
\hline Crawford & 10 & $\begin{array}{l}1913 \\
1915\end{array}$ & $\begin{array}{l}2,826.60 \\
3,088.43\end{array}$ & \\
\hline Dallas & 10 & $\begin{array}{l}1913 \\
1915\end{array}$ & $\begin{array}{l}157.90 \\
165.40\end{array}$ & \\
\hline Davis & 10 & $\begin{array}{l}1913 \\
1915\end{array}$ & $\begin{array}{r}9.80 \\
\ldots \ldots\end{array}$ & \\
\hline Delaware & 10 & $\begin{array}{l}1913 \\
1915\end{array}$ & $\begin{array}{l}496.60 \\
380.40\end{array}$ & \\
\hline Des Moines & 10 & $\begin{array}{l}1913 \\
1915\end{array}$ & $\begin{array}{l}142.50 \\
288.60\end{array}$ & \\
\hline Dickinson & 10 & $\begin{array}{l}1913 \\
1915\end{array}$ & $\begin{array}{l}30.40 \\
28.80\end{array}$ & \\
\hline Dubuque & 10 & $\begin{array}{l}1913 \\
1915\end{array}$ & $\begin{array}{l}104.70 \\
276.40\end{array}$ & \\
\hline Emmet & 10 & $\begin{array}{l}1913 \\
1915\end{array}$ & $\begin{array}{l}44.00 \\
20.50\end{array}$ & \\
\hline Fayette & 10 & $\begin{array}{l}1913 \\
1915\end{array}$ & $\begin{array}{l}333.70 \\
521.20\end{array}$ & \\
\hline Floyd & 10 & $\begin{array}{l}1913 \\
1915\end{array}$ & $\begin{array}{l}244.60 \\
197.10\end{array}$ & \\
\hline Franklin & 10 & $\begin{array}{l}1913 \\
1915\end{array}$ & $\begin{array}{l}113.00 \\
300.00\end{array}$ & \\
\hline Greene & 10 & $\begin{array}{l}1913 \\
1915\end{array}$ & $\begin{array}{l}114.70 \\
114.40\end{array}$ & - \\
\hline Hamilton & 10 & $\begin{array}{l}1914 \\
1915\end{array}$ & $\begin{array}{l}65.70 \\
24.00\end{array}$ & . \\
\hline Hancock & 10 & $\begin{array}{l}1913 \\
1915\end{array}$ & $\ddot{17.50}$ & \\
\hline Hardin & 10 & 1913 & 344.72 & $\begin{array}{l}\text { Total for gophers, wolves and } \\
\text { foxes }\end{array}$ \\
\hline Harrison & 10 & $\begin{array}{l}1915 \\
1913 \\
1915\end{array}$ & $\begin{array}{r}235.80 \\
3,980.06 \\
11,021.50\end{array}$ & \\
\hline Henry & 10 & 1913 & $\begin{array}{l}42.50 \\
56.80\end{array}$ & \\
\hline Iowa & 10 & $\begin{array}{l}1913 \\
1915\end{array}$ & $\begin{array}{l}848.85 \\
950.00\end{array}$ & \\
\hline Jasper & 10 & $\begin{array}{l}1913 \\
1915\end{array}$ & $\begin{array}{l}2,220.55 \\
2,068.70\end{array}$ & \\
\hline Jefferson & 10 & $\begin{array}{l}1913 \\
1915\end{array}$ & $\begin{array}{l}132.00 \\
139.00\end{array}$ & \\
\hline Johnson & 10 & 1913 & $\begin{array}{r}625.00 \\
1,146.59\end{array}$ & \\
\hline Jones & 10 & $\begin{array}{l}1913 \\
1915\end{array}$ & $\begin{array}{l}322.80 \\
301.40\end{array}$ & . \\
\hline Kossuth & 10 & $\begin{array}{l}1913 \\
1915\end{array}$ & $\begin{array}{l}30.80 \\
41.20\end{array}$ & \\
\hline
\end{tabular}




\begin{tabular}{|c|c|c|c|c|}
\hline County & $\begin{array}{l}\text { RATE } \\
\text { (CENTS) }\end{array}$ & Date & $\begin{array}{l}\text { ON POCKET } \\
\text { GoPHERS }\end{array}$ & REMARKS \\
\hline \multirow[t]{2}{*}{ Lee } & 10 & 1913 & 12.20 & \\
\hline & & 1915 & 28.70 & \\
\hline \multirow{2}{*}{ Linn } & 10 & 1913 & 376.90 & \\
\hline & & 1915 & 596.80 & \\
\hline \multirow[t]{2}{*}{ Lucas } & 10 & 1913 & 168.20 & \\
\hline & & 1915 & 519.00 & \\
\hline \multirow[t]{2}{*}{ Lyon } & 10 & 1913 & $5,554.95$ & $\begin{array}{l}\text { Includes bounties on gophers, } \\
\text { wolves, Franklin's spermo- } \\
\text { phile and striped spermo- } \\
\text { phile }\end{array}$ \\
\hline & & 1915 & 42.50 & \\
\hline \multirow[t]{2}{*}{ Marshall } & 10 & 1913 & 982.70 & \\
\hline & & 1915 & 725.00 & \\
\hline \multirow[t]{2}{*}{ Mills } & 10 & 1913 & $1,617.75$ & \\
\hline & & 1915 & $2,760.75$ & \\
\hline \multirow[t]{2}{*}{ Mitchell } & 10 & 1913 & 117.90 & \\
\hline & & 1915 & 87.70 & \\
\hline \multirow[t]{2}{*}{ Monroe } & 10 & 1913 & 45.00 & \\
\hline & & 1915 & 630.70 & \\
\hline \multirow[t]{2}{*}{ Montgomery } & 10 & 1913 & 645.00 & \\
\hline & & 1915 & $\begin{array}{r}42.06 \\
\ldots \ldots\end{array}$ & No bounties on gophers since \\
\hline \multirow{2}{*}{ Muscatine } & $\cdots$ & 1913 & ….. & $\begin{array}{l}\text { No bounties on gophers since } \\
1911\end{array}$ \\
\hline & & 1915 & & \\
\hline \multirow[t]{2}{*}{ Osceola } & 10 & 1913 & 20.63 & \\
\hline & & 1915 & 13.70 & \\
\hline \multirow[t]{2}{*}{ Palo Alto } & 10 & 1913 & 15.10 & \\
\hline & & 1915 & 3.70 & \\
\hline \multirow[t]{2}{*}{ Plymouth } & 10 & 1913 & 891.16 & $\begin{array}{l}\text { Includes bounties on gophers, } \\
\text { wolves and rattlesnakes }\end{array}$ \\
\hline & & 1915 & 668.54 & \\
\hline \multirow[t]{2}{*}{ Polk } & 10 & 1913 & $3,493.50$ & \\
\hline & & 1915 & $1,456.30$ & \\
\hline \multirow[t]{2}{*}{$\mathrm{Sac}$} & 10 & 1913 & 232.00 & \\
\hline & & 1915 & 186.25 & \\
\hline \multirow[t]{2}{*}{ Scott } & 10 & 1913 & $1,103.70$ & \\
\hline & & 1915 & $1,246.80$ & \\
\hline \multirow[t]{2}{*}{ Union } & 10 & 1913 & 333.60 & \\
\hline & & 1915 & 349.85 & \\
\hline \multirow[t]{2}{*}{ Wapello } & 10 & 1913 & 99.60 & \\
\hline & & 1915 & $1,084.20$ & \\
\hline Warren & 10 & 1913 & 929.90 & \\
\hline \multirow{2}{*}{ Wayne } & 10 & $\begin{array}{l}1915 \\
1913\end{array}$ & $\begin{array}{r}1,062.50 \\
3.60\end{array}$ & \\
\hline & & 1915 & 88.30 & \\
\hline \multirow[t]{2}{*}{ Winnebago } & 10 & 1913 & 168.40 . & \\
\hline & & 1915 & 103.89 & \\
\hline \multirow[t]{3}{*}{ Winneshiek } & 10 & 1913 & $2,786.00$ & Figures include bounties on \\
\hline & & & & $\begin{array}{l}\text { gophers, woodchucks, wolves } \\
\text { and foxes }\end{array}$ \\
\hline & & 1915 & $2,947.40$ & \\
\hline Woodbury & 10 & 1913 & $1,118.15$ & \\
\hline Wright & 10 & $\begin{array}{l}1915 \\
1913\end{array}$ & $\begin{array}{r}3,381.40 \\
53.30\end{array}$ & \\
\hline & & 1915 & 27.68 & \\
\hline
\end{tabular}


In Iowa, control of the pocket gopher is best effected in one of two ways, trapping or poisoning. If the numbers of the pests are not great there is little to choose between the two methods, but if the animals are abundant or distributed over large areas poisoning is the cheaper and more efficient method.

Poisoning.-Among the baits that may be successfully used are parsnip, sweet potato, Irish potato, carrot, beet, celery, and sugar beet. Any of these may be cut up into small cubes and poisoned with strychnia sulphate by inserting a few crystals in a slit made with the point of a knife. Prunes or raisins may be used in place of the vegetables with as good results.

After the baits have been prepared, the tunnels are located by using a probe made of a spade or hoe handle shod with a metal point and with a metal cross-bar for the operator's foot about fifteen inches above the point. When this probe is withdrawn it leaves a hole through which the poisoned bait may be dropped into the runs. The hole may be left open or closed with equally effective results.

Another method of poisoning gophers which has proved effective in North Dakota and which is recommended by the United States Biological Survey, is the placing of cubes of sweet potatoes or parsnips in their underground burrows. The following simple directions will prove useful: "The bait should be cut about an inch long and a half inch square and washed and drained. From a pepper box slowly sift $1 / 8$ ounce of powdered strychnine (alkaloid) and $1 / 10$ of this quantity of saccharine (ground together in a mortar) over about 4 quarts of the dampened baits, stirring to distribute the poison evenly.

"The runways, which are usually 4 to 8 inches beneath the surface, can be located by means of a probe made of any strong handle an inch in diameter and 36 inches long. One end should be bluntly pointed. Into the other end should be fitted a piece of $3 / 8$ inch rod, protruding about 12 inches and bluntly pointed. A foot rest aids in probing in hard soils. By forsing down this iron rod near gopher workings, or a foot or two back of fresh mounds, the open tunnel can be felt as the rod breaks into it. The blunt end of the instrument is now used to carefully enlarge the hole, a bait or two is dropped into the run and the probe hole closed.

"One soon becomes expert in locating the runs, and a man can treat 300 to 500 gopher workings in a day. Baits need be placed 
at only two points in each separate system of 20 or 30 mounds which is usually the home of a single gopher. In fields in which mounds are so numerous that separate groups cannot be recognized, baits inserted into the runs at intervals of 50 or 60 feet will probably kill all the gophers. Small stakes are useful to mark the locations of baits. In our experience, baits placed fairly in the open runs have invariably killed the gophers. The method has found great favor wherever it has been introduced." ${ }_{26}$

Mr. Gwynn, manager of the Welch Nursery of five hundred acres at Shenandoah, informs the writer that gophers cause considerable damage, and that a constant warfare in the way of trapping and poisoning is carried out. Sometimes crystals of strychnia sulphate are placed in apples or pumpkin seeds which are buried along with apple and plum seeds planted for future nursery stock.

Trapping.-In places where gophers are not too abundant trapping gives effective results at a minimum expense. Willis Adams, who does considerable trapping in the vicinity of Chariton, reports that in 1912 on one farm near this place and working an average of from two to three hours daily he caught 664 of these pests. Many other and similar instances have come to hand from time to time.

The ordinary steel trap (No. 0) is successfully employed in most places. To set this trap, open up the inain runway of the gopher with a spade and place the trap so that the top is about level with the bottom of the turnel. The chain should be made fast to a stake or heavy object and the hole closed with boards and sod in order to exclude light.

There are other and special gopher traps which are used effectively, and these are often set in the laterals as well as in the main runways. One of the best of these traps is the Macabee Gopher Trap, which is made and sold by Z. A. Macabee, Los Gatos, California. Size No. 3 is best for use against our pocket gopher. Directions for proper setting accompany the traps, which cost about $\$ 2.00$ a dozen.

In setting these traps, after selecting the freshest mound of earth, the trapper should dig back with a trowel to the open part of a lateral and place the trap there. The hole should be covered

${ }^{25}$ Bell, W. B., and Piper, Stanley E.. Extermination of Ground Squirrels, Gophers and Prairie Dogs in North Dakota: N. Dak. Agr. Exp. Sta., Circ. 4, $9-10,1915$. 
to exclude light. In looking over the mounds of earth that have been thrown out by the gophers, a slight depression about three inches in diameter will be noticed; this indicates the spot to begin digging.

Although success in trapping may not be met with on the first few attempts, by a little persistence experience will be gained and with it better results. Trapping is safe, sure, efficient, and inexpensive.

\section{JUMPING MICE.}

\section{Family ZAPODIDA.}

The jumping mice of North America are found only in the boreal and semi-boreal regions and are nowhere abundant, though distributed from Hudson Bay to North Carolina and from Alaska to New Mexico and California. In Iowa, two forms belonging to a single genus have been recorded; but they are not sufficiently common to be considered of economic importance, and in many places the capture of a specimen arouses considerable local interest.

\section{HUDSON BAY JUMPING MOUSE.}

\section{Zapus hudsonius hudsonius (Zimmermann).}

Dipus hudsonius Zimmermann, Geog. Gesch. Mensch. u. vierfüss. Thiere, II, 358, 1780 .

Description.-About the size of the common house mouse, but with the tail and hind legs markedly longer and more slender; color above tawny to yellowish brown mixed with darker hairs, the bases of the hairs plumbeous; a broad dorsal stripe running from top of head to base of tail, is distinctly darker than the rest of the upper parts; lower parts and feet white with usually a distinct yellowish brown line separating the color of the upper and under parts; tail dark above, whitish below.

Measurements.-Total length, 8.00 inches; tail vertebræ, 5.00 inches; hind foot, 1.20 inches.

In spring and early fall this mouse is noticeably darker in oolor than in summer and the dark dorsal stripe is in part obliterated.

On account of its elongated tail and hind legs and its peculiar method of locomotion when disturbed, this mouse is not likely to be confused with any of our other forms except the following subspecies whose distribution in the state is apparently much more limited. 
The Hudson Bay jumping mouse inhabits meadows, shrubby fields, and thickets bordering woodland. Often it is found in damp situations along fences. It is most often seen during the haying season, when it is driven from its hiding place while the grass is being eut.

The little animal is well named, for when disturbed it moves away by a series of leaps or jumps, sometimes remaining motionless for a moment between leaps. Ordinarily, the distance traversed in one of these leaps is from six to eight feet, though if occasion requires this distance can be increased. The animal is assisted in leaping by the long tail, which aids it materially in keeping its balance while in the air.

Jumping mice do not follow beaten paths or runways as is so often observed among meadow mice, but appear to wander about, following, to some extent, natural paths and open places.

Toward the latter part of the summer a rounded nest four or five inches in diameter is constructed. This nest is usually concealed under rocks, bushes, or dried grass and has an entrance hole at one side. Two individuals, probably a pair, occupy this type of nest which is used only at the close of the breeding season.

The nest in which the young are brought forth is usually underground, but in some eases in a hollow log or stump. The young are from three to six in number and are produced in May or June.

Hibernation apparently occurs in this latitude, beginning at the time of the first heavy frosts and lasting until spring. "The animals are generally found singly (sometimes in pairs) in nests in holes at a depth varying from a few inches to 2 or 3 feet below the surface. They lie rolled up like a ball with the feet close together and tail curled about them. If removed from the nest and subjected to a moderate degree of heat they revive and in the course of a few hours move about freely, but generally resume their lethargic state if again exposed to the cold. The pulse and respiration are very slow." ${ }^{27}$ Hibernation is also said to take place in a nest above ground.

The food of the jumping mouse consists, in cultivated areas, of various grains as well as grass and weed seeds; when it inhabits the vicinity of wooded places it feeds upon the seeds and nuts of trees. Sometimes, during the summer, stores of food are laid up

27Preble, E. A., North American Fauna, No. 15, 8, 1899. 
in nests or burrows, but it is probable that the animal does not use this food since it usually remains quiescent throughout the cold season.

While the Hudson Bay jumping mouse undoubtedly occurs throughout the state, it seems to be more common in the prairie regions. The few definite locality records which have been obtained are as follows-a mounted male specimen (No. 3931) in the Museum of the State University of Iowa was collected at Oskaloosa in 1889. The Coe College Museum possesses two mounted specimens, one collected at Britt, August 20, 1911; the other bears no data, although B. H. Bailey assured the writer that it was collected "somewhere" in Iowa. A female specimen of this species collected near Pomeroy was sent in to the University Taxidermist's Laboratories, March 20, 1916. The animal had been killed a few days previously. T. C. Stephens of Morningside College reports three specimens of this form captured near the Iowa Lakeside Laboratory in the summer of 1915.

\section{PRAIRIE JUMPING MOUSE.}

Zapus hudsonius campestris Preble.

Zapus hudsonius campestris Preble, N. Amer. Fauna, No. 15, 20, 1899.

Description.-Summer: Color above similar to brightly colored specimens of the preceding form; dorsal area distinct, suffused with ochraceous buff, the sides ochraceous buff; under parts and feet white; tail dark gray above, yellowish white below. Fall: Sides yellowish; the dorsal area almost black, the hairs tipped with yellowish; upper surface of tail darker than in summer, and ears darker and bordered with whitish.

Measurements.-Total length, 8.75 inches; tail vertebræ, 5.30 inches; hind foot, 1.10 inches.

This form is very similar to the preceding, differing from it mainly in its slightly larger size, its brighter color, and higher brain ease. The area of intergradation of the two forms includes the western part of Iowa, the present form being distributed from Manitoba south over the Great Plains to Nebraska and west to Colorado and Wyoming. The prairie jumping mouse is said to replace the Hudson Bay jumping mouse over the northern and more elevated portions of the plains west of Minnesota and Towa to the base of the Rocky Mountains. 
Definite locality records are not at hand for this form, and observers and collectors should be on the lookout for specimens so that the distribution within the state may be definitely worked out.

\section{AMERICAN PORGUPINES.}

\section{Family ERETHIZONTIDE.}

The American Porcupines are so entirely different from our other rodents, or, indeed, from any other group of mammals that they are readily distinguished. In North America the family is represented by a single genus which contains five forms, while South and Central America have representatives placed in cther genera. These latter have long tails fitted for grasping while the North American species have short, blunt and spiny tails. All the American forms are short-legged, slow-moving, more or less arboreal animals with a thick body-covering of hairs mixed with quills. A good deal of superstition has been associated with these quills. While they are loosely attached to the skin of the animal and become detached very easily, the animal is not able to "shoot" them at an adversary as has been so often stated. These quills are barbed or serrate, so that if they once become embedded in the skin the efforts of the victim to remove them will usually only cause the quill to work into the flesh still more deeply.

The porcupine inhabits forests and spends most of its time in trees, from which it obtains a large share of its food. Leaves, twigs, and bark of maple, basswood, birch, and hemlock are most preferred; but others are utilized when these are not available. "In Canada and in the northern portion of Michigan and Wisconsin they frequent the vicinity of lumber camps and show a decided fondness for any substance which has a salty flavor, such as old pork rinds, and they have often been known to gnaw to pieces old butter firkins and boxes which have contained salty food of any kind." 28

Porcupines are, in the main, nocturnal in habits, though they occasionally wander forth in the daytime. On the ground their movements are slow and awkward and they depend for safety upon the formidable array of sharply pointed and barbed spines.

${ }^{28}$ Cory, Chas. B., Mammals of Illinois and Wisconsin: Pub. Field Mus. Nat. Hist., Zool. Ser. XI, 257, 1912. 


\section{CANADA PORCUPINE.}

\section{Erethizon dorsatum dorsatum (Linnæus).}

[Hystrix] dorsata Linnæus, Syst. Nat., X ed., I, 57, 1758.

Description.-Hairs of upper parts mixed with quills or spines, the hairs long and entirely or almost concealing the quills on the lower back, hips, and sides of base of tail; general color above dark brown to nearly black varied with yellowish white; quills white at base, the apical third usually black; often a few quills are entirely black or white; length of quills variable, the longest from three to four inches; color beneath brownish black.

Measurements.-Total length, 35.00 inches; tail vertebræ, 5.50 inches; hind foot, 3.50 inches.

The writer has been unable to find any recent records of the Canada porcupine in Iowa, but it is probable that in earlier days the species occurred sparingly in the northern and particularly in the northeastern part of the state. With the cutting of the forests and the settling of the country the animals have practically disappeared. J. A. Spurrell writes that a porcupine was killed in Grant City (Sac county) in 1854. T. Van Hyning gives the following record: "In about 1908 'some hounds in the same section,' Allamakee County, 'were badly stuck.up by porcupine quills, which had to be pulled from their mouths. Last summer, on French Creek, Allamakee County, I saw some scrub Hemlocks freshly cut and gnawed by porcupines.' Ges. H. Berry, Cedar Rapids, Iowa, April 8, 1913.'" 29

\section{HARES AND RABBITS.}

Family LEPORIDE.

The members of this family are widely distributed throughout the United States but only two forms are at all common in Iowa. A great number of subspecies and geographical races have been described and this leads to some confusion in the matter of determining them. Two genera, probably represented in Iowa by but four species, make the task of separating our forms less arduous. Two of the Iowa forms herein discussed occur very rarely in the state, so that there is little danger of confusion.

Ordinarily the terms hare and rabbit are used interchangeably as applying to members of this family; but properly, the word hare is restricted to those forms which do not live in burrows in

${ }^{20}$ Van Hyning, T., Proc. Ia. Acad. Sci., XX, 311, 1913. 
the ground and whose young are born with a well developed coat of hair and with the eyes open; rabbits, on the other hand, live in burrows and the young are born naked and with the eyes closed. Of our species, then, the members of the genus Lepus are properly called hares, while the members of the genus Sylvilagus, and other genera not represented in Iowa, are properly termed rabbits. Common usage makes it unlikely that the names "jack rabbit," "snowshoe rabbit," etc., will be changed to meet this strictly scientific demand.

It is a well known fact that hares and rabbits are exceedingly prolific, from four to six young being born at a time and two or sometimes three litters being produced in a year. In some cases the animals begin to breed when they are six months old.

While a good deal is known of the habits of the forms occupying the more populated regions of the United States, much remains to be found out concerning details of life history of even the well known species. Most species are mainly nocturnal, although the jack rabbit and even the cottontail moves about in daytime particularly if the weather is cloudy. If food is scarce both hares and rabbits become more diurnal. "All the species of Lepus make nestlike 'forms' in sheltered spots, in which they conceal themselves during the day; although in summer Lepus campestris [White-tailed jack rabbit] sometimes uses the deserted holes of other mammals, and in winter burrows into the snow for protection from the bitter cold, and from the birds and beasts of prey in the open where it lives.

"Most members of the genus Sylvilagus [this genus contains the cottontails] use both forms and the deserted burrows of other mammals, or find shelter under rocks, roots or trees and similar places. Forms are in common use in summer and in regions which have a warm winter climate but some species habitually use old burrows, which they sometimes enlarge. The forms are usually made under the shelter of dense herbage or under low brushy growths, and the owner spends the day in them regularly for considerable periods. The females of many, if not all, species of Sylvilagus make soft, warm nests of fine grass, leaves and other vegetable material, lined with hair from their own bodies, and in these nests the young are born and lie concealed like mice in a nest, while small and helpless. The nests of cottontails are usually placed in a bowl-shaped depression in the ground in some sheltered spot, 
and during the absence of the parent the young are covered and completely concealed by the material of the nest. At such times the top of the nest is so like the surrounding surface of the ground: on which lie dead leaves and grasses, that its presence can be detected only by chance." ${ }_{30}$ The young are suckled in the nest for about three weeks and then are left to shift for themselves.

The pelage of hares and rabbits varies in length and thickness according to climate. Its color responds readily to climatic influences, also, a fact which accounts in large part for the great number of recognized geographical races. The pelage is thickest on the back, and is made up of three sets of hairs which are best differentiated in this region; a short dense underfur, a longer coarser coat of hairs, and a still longer coarser and thinner set of hairs the tips of which overlie the middle coat. Differences in pelage due to age are to be noted also; the juvenal pelage is soft and woolly and is carried until the animal is about half grown when it gives place to the postjuvenal pelage which is characterized by the greater development of the middle hairy coat. The postjuvenal pelage is retained until the animal is almost full grown, when the typical adult pelage takes its place. This pelage has the characteristic coarse hairs of the middle coat accompanying the long black hairs of the back.

Of our representatives of the family the varying hare and whitetailed jack rabbit have two annual molts, while the great plains jack rabbit and the cottontail molt but once during the year. In the two former the change from the white winter coat to the dark summer coat is brought about only very gradually. In the two latter the single molt usually occurs in the late summer or early fall.

Among American rabbits, variation due to sex is not marked, though usually very old females are slightly larger than males of the same age. However, individual differences in coloration, size, length of ears, hind feet, proportion and size of skull are very marked, thus adding to the difficulty of delimiting closely related forms. Many forms are also subject to much variation due to environmental conditions, while other forms seem to be little affected.

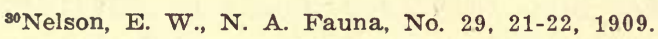


Wherever the number of hares and rabbits is excessive in an agricultural territory they are destruetive to fruit trees, nurseries, grape vines, and erops in general. In Iowa the cottontail is abundant almost everywhere and is to be considered an enemy of the fruitgrower and agrieulturist. Jack rabbits are much larger than cottontails, but are not common enough in Iowa to be of much economic importance. However, on account of their large size, even if present in small numbers they may eause considerable damage.

"Rabbits are striet vegetarians, animal food never being eaten by the adults. They cat all sorts of herbage-leaves, stems, flowers and seeds of herbaceous plants and grasses, and leaves, buds, bark, and fruit of woody plants or trees. The most sueeulent kinds, sueh as young shoots, tender garden vegetables, elover, alfalfa, and fallen ripe fruits are generally preferred; but when these fail, any green vegetable growth seems to be acceptable, and the bark of trees is often resorted to when deep snows eover other supplies or during long summer droughts." ${ }_{31}$

Considerable damage by rabbits to trees and nursery stock is reported from many parts of the state. At Corning, in 1915, it is reported that most of the nursery salez during that season were on stock to fill out orchards which had been damaged by rabbits. Henry Field of the Henry Field Seed Company, Shenandoah, reports more field damage from rabbits than from any other rodents. Mr. Gwynn, manager of the Welch Nursery at Shenandoah, hears out this statement, and says further that the greatest damage to nursery stock is done in winter and early spring after heavy snows, and particularly where drifts have blown up. Here small trees are girdled and eventually die. Similar reports come from other places in the state.

Methods of control are considered under the discussion on the cottontail.

Rabbits are our commonest and most widely distributed game animals, and during fall and winter are hunted persistently all over the state. Since their meat is high in food value, this, in part, makes up for some of their destructive qualities. The skins and fur are also used in the industries.

${ }^{31}$ Lantz, D. E., Yearbook, U. S. Dept. Agriculture, 1907, 331. 


\section{MINNESOTA VARYING HARE. VARYING HARE. SNOW-SHOE RABBIT.}

\section{Lepus Americanus phaeonotus Allen.}

Lepus. Americanus phaeonotus Allen, Bull. Amer. Mus. Nat. Hist. XII, 11, March 4,-1899.

Description.-Summer: Color above brown and ochraceous buff mixed with blackish; head and middle of back darkest; upper surface of tail buffy or dusky gray, below white; tops of fore feet and fore legs tinged with rusty brown; ears bordered with black, the posterior half whitish with a broad black margin; inside of ears grayish; color below white except throat which is brownish; sometimes color of sides also encroaches on the white. Winter: Pure white except tips of ears, which are bordered with black and sometimes with brownish buff in front of them. During spring and fall irregular markings of brown and white are evident when the semi-annual change of pelage occurs.

Measurements.-Total length, 18.00 inches; tail vertebræ, 1.50 inches; hind foot, 5.25 inches.

Habits, Distribution, Etc.- This is an exceedingly variable form which prefers wooded regions in which there is dense undergrowth. The nest is a mass of dried grass lined with fur furnished by the mother, and is usually concealed in weeds or thickets. From two to four young are found in a litter; they are haired and have the eyes open when born.

The food of this species is made up of grasses, leaves of various shrubs, clover, and bark of young trees. In some places outside of the state it causes considerable damage by eating the barls of fruit trees and grape vines; garden crops also are damaged to some extent. While the animals usually feed at night they are often seen during the daytime.

The writer has no definite locality records for the varying hare in Iowa, but it is included here on the evidence of Pellett and Van Hyning in their "Annotated Catalogue of the Recent Mammals of Iowa", 32 in which the following information is given: "Mr. Pellett has seen specimens taken in Iowa."

It is stated also by residents and hunters in northwestern Iowa that a rabbit different from the jack rabbit cecurs there, and it may be that this is the form to which reference is made. Hunters

${ }^{32}$ Van Hyning, T., and Pellett, Frank C., Proc. Ia. Acad. Sci., XVII, 212, 1910. 
and collectors should be on the lookout for this species in order tr; definitely affirm the above data, so that specimens and exact localities may be available for reference.

\section{WHITE-TAILED JACK RABBIT. JACK RABBIT.}

\section{Lepus townsendi campanius Hollister.}

Lepus campestris Bachman (nomen præoce.) Journ. Acad. Nat. Sci. Philadelphia, VII, part 2, 349-353, 1837.

Lepus townsendi campanius Hollister, Proc. Biol. Soc. Wash. XXVIII, 70, March 12, 1915.

Description.-Summer: Color above, nearly uniform, varying from pale yellowish gray to brownish gray, the brownish color of under-fur showing through; rump similar to rest of back, but a little paler at sides; entire tail usually white; front and outside of fore legs and feet dull buff; anterior border of ears with brownish buff; posterior half of cutside of ear white with a broad terminal black patch which includes border of ear at tip; inside of ear with a long dusky patch near posterior side; posterior border whitish or buffy; color below white except under side of neck . which is dull yellowish or grayish buff. Winter: Usually pure white except irregular areas of reddish buff on tops of fore feet, nose, and about eyes; front and inside of ears reddish brown; the underfur reddish brown which shows through when the overlying white coat is disturbed.

Measurements.-Total length, 24.00 inches; tail vertebrae, 3.50 inches; hind foot, 5.80 inches.

This form resembles somewhat the varying hare, but may be recognized by its larger size, its long ears tipped with black, and the much longer tail which is entirely white.

The jack rabbit is our largest representative among the rablits. It has two annual molts, but is subject to considerable color variation, particularly in summer. This is more pronounced on the head and body, which may vary from dark yellowish buffy with the underfur of a dusky brown color to paler and brighter buff varying to grayish buff.

Habits, Distribution, Etc.-This animal has been included in all the published lists of rodents of the state and has been indicated as becoming more common and as increasing its distribution to the east and south. In the Proceedings of the Iowa Academy of 
Sciences for 1888, Professor Herbert Osborn lists one specimen taken at Ames. In a later paper, "A Partial Catalogue of the Animals of Iowa" (1891), he again mentions this form and says, "Becoming common in some of the northern counties." Professor C. C. Nutting in his paper, "Report of the Committee on State

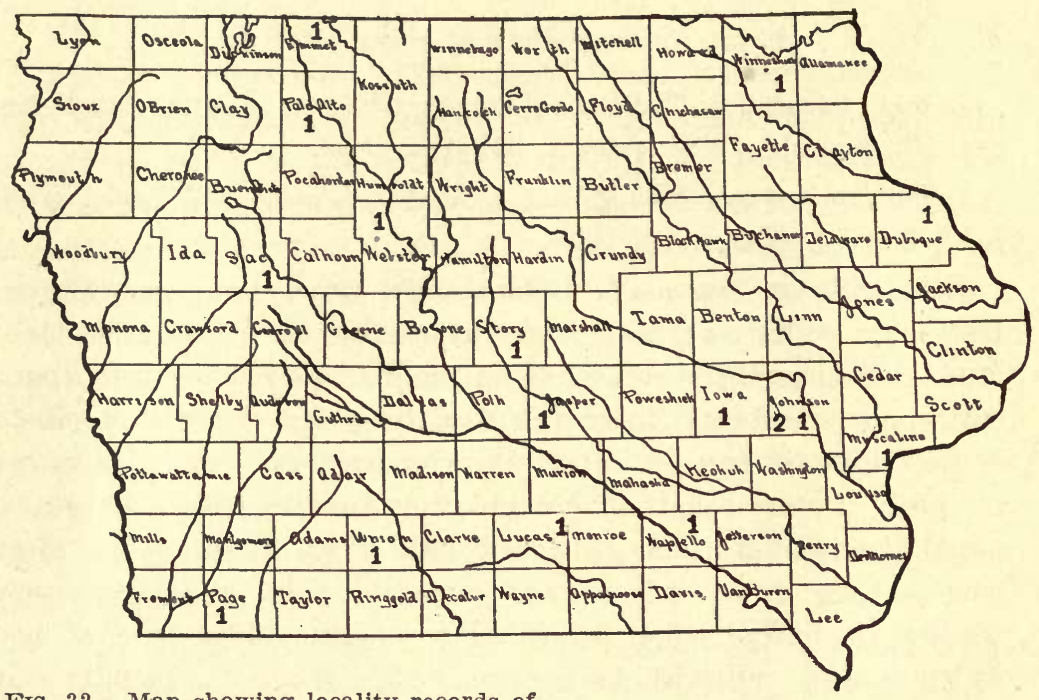

FIG. 32.-Map showing locality records of-

1. White-tailed Jack Rabbit (Lepus townsendi campanius).

2. Great Plains Jack Rabbit (Lepus californicus melanotis).

Fauna" ${ }_{33}$ says, "this species is slowly working its way south. Last year it was reported by Prof. Witter from Muscatine county and during the past fall a specimen was killed in Johnson county, and is now in the State University Museum." Three other specimens are in the State University Museum; an adult mounted specimen taken at Iowa City January 19, 1895, and two immature specimens taken in Emmett county in 1897. M. X. Geske of McGregor informs the writer that this species is coming into that locality and that the numbers have been on the increase during the past twelve years. At Creston, Ottumwa, and Chariton the species is reported as rare. Mr. Gwynn, manager of the Welch Nursery at Shenandoah, informs me that three specimens were taken at that place during the winter of 1914 . In practically all the northerm counties reports indicate that the jack rabbit is becoming more abundant and is increasing its distribution to the east and south. At Decorah it is reported to have come in only during the past

\footnotetext{
s3Proc. Ia. Acad. Sci. Vol. I, part III, 40, 1892.
} 
six or seven years. M. P. Somes informs the writer that he has taken specimens at Fort Dodge, West Bend, and Ruthven. J. A. Spurrell of Wall Lake writes as follows: "Jack rabbits or prairie hares, are becoming more plentiful yearly but the first record I can find is of one seen in the southern part of the county (Sac) in 1868 or 1869 . One was killed near Lake View in 1870 and it was five years before the hunter saw another. They did not become numerous until 1890 to 1900 .' 34 The writer has seen or has in his eollection specimens from the following additional localities: Marengo, Wall Lake, Estherville, and Jasper county.

The jack rabbit is scarcely abundant enough in the state to be considered of particular economic importance, but such control measures as may be necessary are equally applicable to Mearns' cottontail and will be found under the discussion of that species further on in this paper.

\section{GREAT PLAINS JACK RABBIT.}

\section{Lepus californicus melanotis Mearns.}

Lepus melanotis Mearns, Bull. Am. Mus. Nat. Hist., II, No. 4, 297-303, February, 1890.

Description.-Winter: General color above deep ochraceous buff varying to light ochraceous buff overlaid with blackish; sides of body paler; rump patch gray, large and conspicuous and divided by a broad blackish band extending over upper side of tail ; front of fore legs and tops of fore feet buffy, a little darker than the body; front of hind legs and top of hind feet pure white; inside of ears deep buff with a narrow white border on posterior edge, a black border on tip, and a brownish border posteriorly; color below white or grayish white.

Measurements.-Total length, 22.00 inches; tail vertebræ, 3.10 inches; hind foot, 5.10 inches.

The coloration of this form is variable as to individuals, season, and geographic location but the characters above will serve to differentiate it from any of our other forms. Only a single specimen of the great plains jack rabbit has thus far been taken in the state, and Iowa is so far from its supposed normal range that its appearance here can scarcely be considered more than accidental. The specimen was taken in the southern part of Johnson county

${ }^{34}$ History of Sac County, Iowa, by Wm. I. Hart, publişhed by B. F. Bowen and Co., Indianapolis, Indiana. 
in the autumn of 1915 . E. W. Nelson of the United States Biological Survey gives the geographical distribution of this ?orm as follows: "Great Plains from east central and northern Texas, northeastern New Mexico and north through western half of Indian Territory, all of Oklahoma, extreme southwestern part of Missouri, all of Kansas and Nebraska, except perhaps extreme eastern parts, southwestern Dakota, southeastern Wyoming, and all of Colorado east of Rocky Mountains." ${ }^{\text {, }}$ see also the map on page 132.

\section{MEARNS' COTTONTAIL RABBIT. COTTONTAIL. GRAY RABBIT.}

Sylvilagus floridanus mearnsi (Allen).

Lepus sylvaticus mearnsi Allen, Bull. Am. Mus. Nat. Hist., N. Y. VI, 171, 1894 (footnote).

Description.-Color above pale yellowish brown, with an uver. lying wash of blackish; sides of head and body paler; rump dull gray, forming a rather distinct rump patch; nape tinged with rufous brown or rusty brown; tail above dull brownish tinged

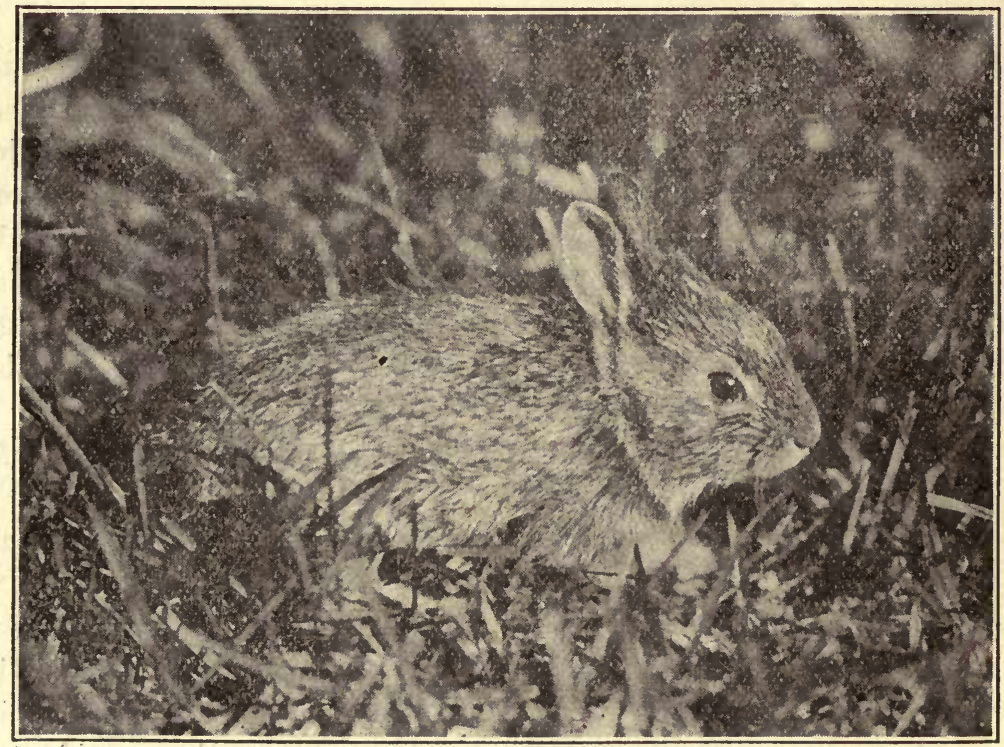

Fig. 33.- Young Cottontail at about the time of leaving nest. Photo from life by Frank C. Pellett.

${ }^{6}$ Neløon, E. W., N. A. Fauna, No. 29, 146, 1909. 
with grayish; under surface white; upper surface of legs pale brown; outside of ears buffy grayish, plainly bordered with black along front margin and at tip; inside of ears dull gray; color below white; under side of neck dark buffy.

Measurements.-Total length, 17.80 inches; tail vertebræ, 2.45 inches; hind foot, 4.00 inches.

This, like most other members of the family, is a variable form but is not likely to be confused with any of our other species.

Habits, Distribution, Etc.-The cottontail is our commonest species of rabbit and is usually found in thicketed woods and in open country supporting underbrush. It is also fond of frequenting gardens, particularly if there are bunches of weeds and bushes or tufts of grass under which it may construct its "forms." It does not make burrows, but often oceupies holes in the ground or in hollow logs. The cottontail is timid and gentle and when

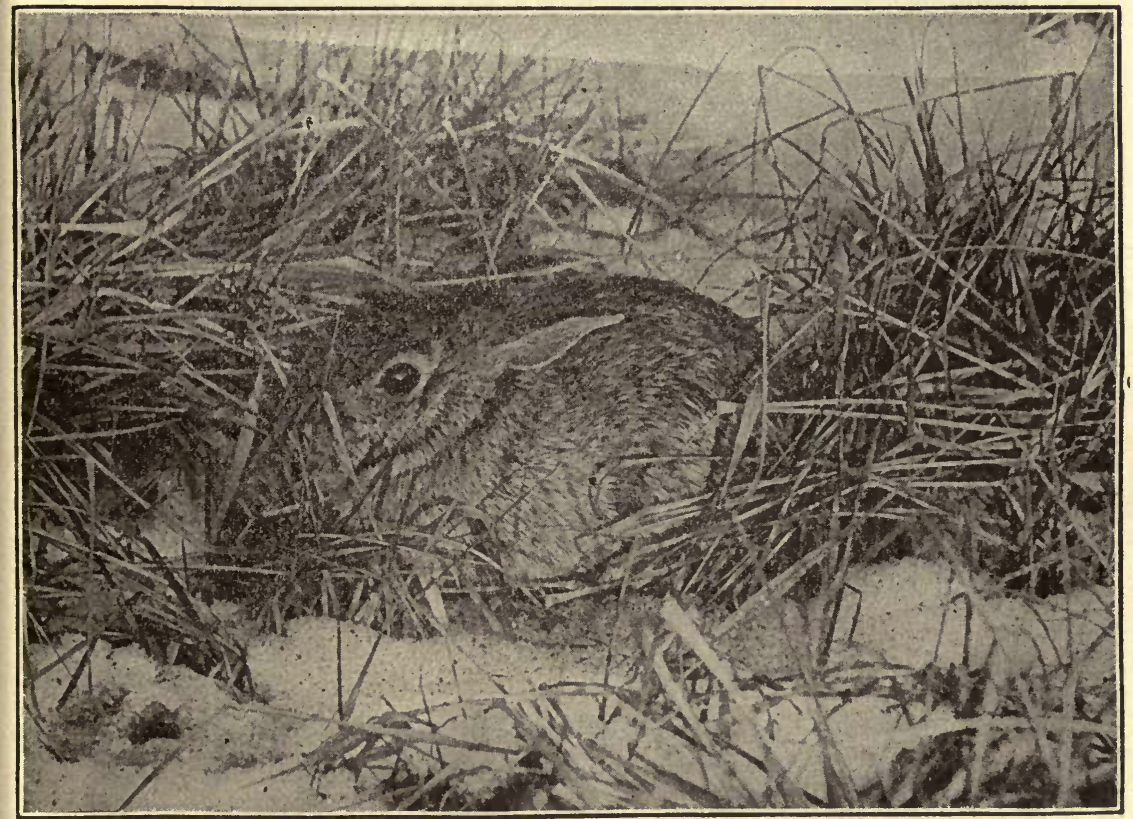

FIG. 34.-Cottontail Rabbit in its "Form." (From U. S. Department of Agriculture, Bureau of Biological Survey.)

eaught does not attempt to bite but often utters a shrill squeal. Although it is practically defenseless, the senses of hearing, sight, and smell are strongly developed as are those senses in other 
members of the family. When feeding undisturbed, cottontails move about leisurely by short hops; but when frightened they make good use of their long, muscular hind legs, and progress very rapidly by a succession of leaps of from eight to ten feet. They are able to maintain a sharp pace for a eonsiderable time.

The cottontail is common or even abundant in practically all parts of the state, and specimens are at hand from or have been seen in almost every locality visited.

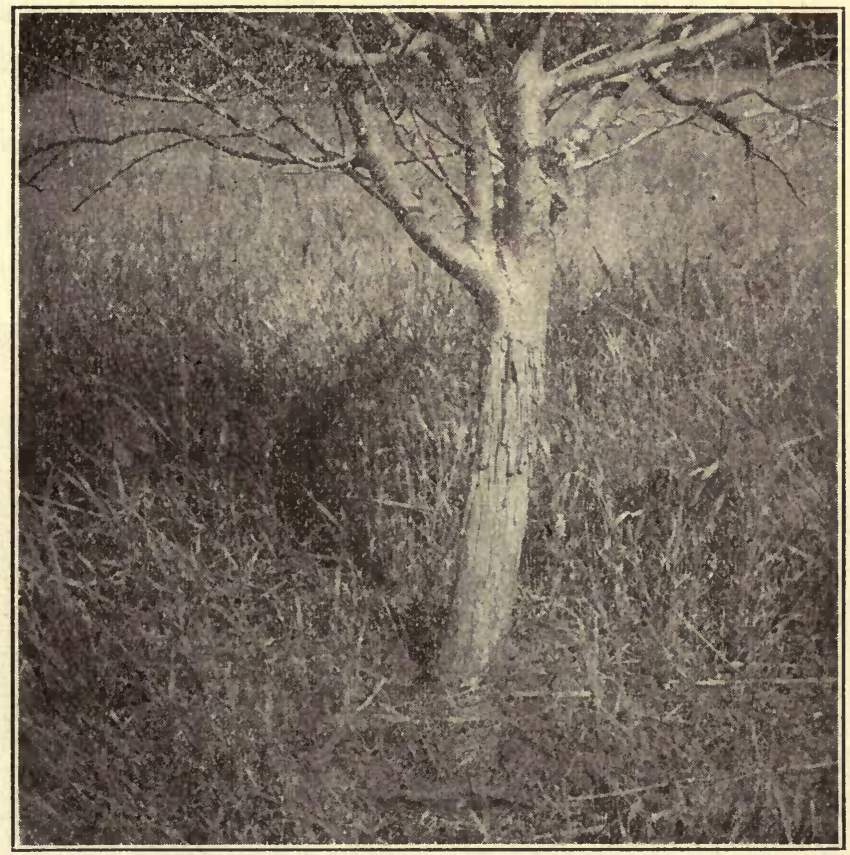

FIG. 35.-Apple tree killed by Rabbits. (From U. S. Department of Agriculture, Bureau of Biological Survey.)

Food Habits, Economic Importance, and Control Measures.-The food of the cottontail, in general, is included in the foregoing discussion of the family. In summer, grass, leaves of shrubs, bark of trees, clover, alfalfa, and corn; in fall, apples, cabbages, turnips, and other garden vegetables; and in winter, the twigs and bark of woody plants and trees form its principal articles of diet. It is especially ford of peas and cabbages and market gardens are in numerous instances damaged considerably. Trees and shrubs are injured either by the bark's being eaten or by the tips of 
branches and twigs being cut off. Some of the damage done by field mice is often attributed to rabbits; the tooth marks of the former, however, are small, and they usually begin their work at or below the surface of the ground; rabbits, also, usually tear off the bark in strips. In addition, in many cases nurseries of young fruit and ornamental trees and shrubs are severely damaged by rabbits.

Such a prolific and destructive animal must be held in elseck in some way, else it so increases as to berome a menace to agriculture. Among the natural enemies of the cottontail which are especially effective in reducing their numbers are the hawks, owls, and earnivorous mammals. Of the former msy be mentioned the marsh hawk, Cooper's hawk, Swainson's hawk, red-tailed hawk, rough-legged hawk, long-eared owl, short-eared owl, barred owl, and great horned owl. At least some of these birds are found in every locality in the state; and as practically all of them feed upon other noxious animals, they should be protected and not ivantonly destroyed. Of the mammals, wolves, foxes, minks, weasels, and domestic dogs and cats are effective in keeping down the numbers of rabbits.
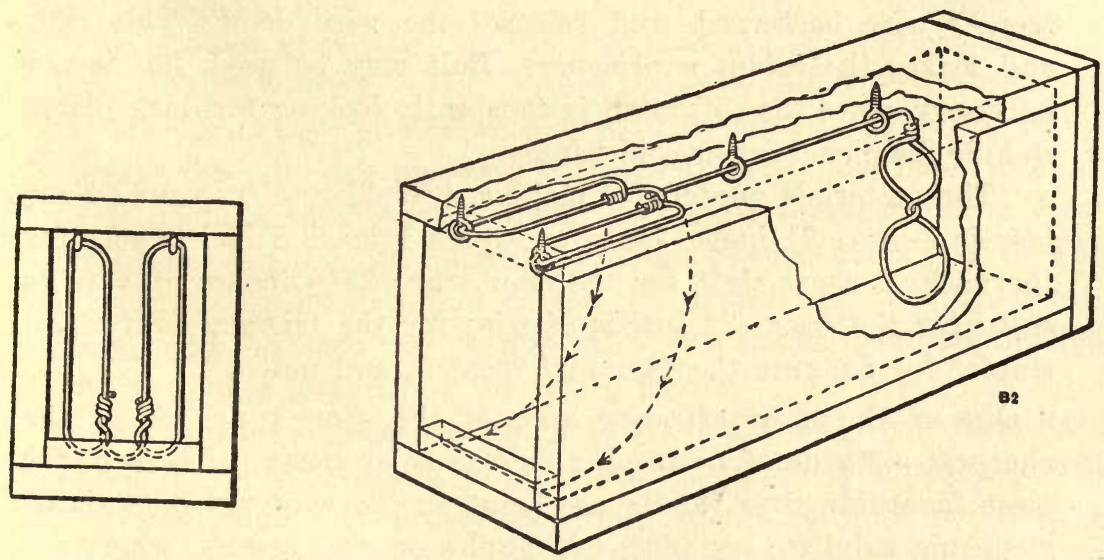

FIG. 37.-Details of a Wellhouse Rabbit trap. (From U. S. Department os Agriculture, Bureau of Biological Survey.)

In Iowa, at least, hunting has been the most effective method for holding in check the number of rabbits and of the methods of hunting, shooting seems to be generally chosen. The manager of the Welch Nursery at Shenandoah informs the writer that, with them, hunting is the most suceessful method of combating the cotcontail and the proprietors of the nursery employ hunters and 
furnish guns and ammunition ciuring practically all the winter months. Ferreting is practiced on a small scale in some localities, as is also the use of the beagle, in which case the gun is depended upon to kill the game.

Rabbits are easily trapped, and this method of destruction is quite widely practiced in the state. Although slow it is practicable in gardens, orchards, and nurseries. The old fashioned box trap with a figure-4 trigger, the details of whose eonstruction are known to almost every boy, is most often employed.

Another form of trap known as the "Wellhouse" trap and used very suecessfully in Kansas is easily constructed. "The trap is a box made of 6 -inch fencing bcards, old ones being preferred. The box is about 21 inches long, closed at the back by a board, but in front by a wire door only. The door is hung from the top and swings inward. A cleat at the bottom prevents its opening outward. The trap is set and the wire door is kept open by a wire trigger-rod, held in place by two staples fastered to the top of the box. This trigger is bent downward near the rear of the trap and formed into a loop or a figure eight. As the rabbit enters the trap and erowds into the back part, it pushes upon the loop, moves the trigger wire backward, and releases the wire door. This falls and makes the rabbit a prisoner. Bait may be used, but is not necessary, since the cottontail is constantly looking for dark plices to hide from enemies or cold winds.

"The materials needed for making a Wellhouse trap are: Four boards 1 by 6,21 inches long; one piece 1 by $\epsilon, 8$ inches long for the back; a short eleat for the door stop; $281 / 2$ inohes of wire to serve for the door; 22 inches of wire for the trigger; four small staples for hanging the door and trigger; and nails.",

One of the most effective and, at the same time one of the eheapest methcds of destroying rabbits is by means of poison, the most favorable time for its use being in the winter. Crystals of strychnia sulphate are placed in apples or ripe prunes, which are then scattered along the paths or runways frequented by the rabbits. The poisoned baits may be placed on the ground or raised on a short stick. This plan has proved effective in some of the nurseries of the state. Another method of poisoning rabbits in winter is to cut small twigs from apple trees and dip them into a solution of strychnin and sugar, after which they are scattered

\$8Lanț, D, F., Yearbook, U. S. Dept. Agriculture, 1907, 337-338, 
along paths and runways. With this method there is little danger of poisoning other animals than rabbits and field mice. Whenever poisoned baits of any kind are used, great precautions should be taken that human beings and farm animals are not aecidentally poisoned. In addition, the carcasses of poisoned rabbits should be buried whenever found.

If rabbits are abundant and the area to be protected is not great, such as a small block of nursery trees or a garden, a woven wire fence from 30 to 36 inches in height and of sufficiently fine mesh to keep out the animals may be employed. Sumetimes the lower edge is turned outward and covered with soil, or a barbed wire is stretched along the ground beneath it to prevent the rabbits srom digging under it. This method of protection is practiced in Jowa and is effestive unless the snow drifts badly thereby allowing the animals to walk over the fences.

Many devices and washes have been used and recommended for the protection of trees. One of the most effective and one which is applicable to both rabbits and field mice may be mentioned here. The formula for this wash, in the same proportions as given by Lantz (l. c. 340 ), is as follows :

Unslaked lime .......................... pounds

Flowers of sulphur.......................

Water to make......................9 to 10 gallons

Mr. Lantz says of this wash: "A little salt may be added to increase the adhesive property of the mixture. The lime, sulphur and about a third of the water are boiled together for at least one hour and the full quantity of water is then added....... For protection from mice and rabbits the trunks only require treatment and the wash may be applied with a brush. One application in November should last the entire winter."

Various mechanical means for protecting young fruit trees have been tried out, of which three or four of the most dependable will be mentioned. If protection from rabbits only is required, a woven wire netting, twenty-four to thirty inches wide and with a one-inch mesh, is recommended. Cut the wire into one-foot lengths and roll each section about the trunk of a tree, fastening the ends by bending the wires together; the wire should not be in contact with the trunk. This makes a permanent and effective protection. If the trees are to be protected rom field mice also a netting of closer mesh must be used, wire window screen netting being excellent for this purpose. 
Cloth wrappings well fastened offer effective protection, but should be removed in spring as they afford hiding places for destructive insects. Cornstalks are sometimes used for the protection of trees. They are cut into two foot lengths, split, and tied with the flat side towards the tree so that the trunk is eompletely surrounded. Various forms of wood protectors also are employed; and if pressed into the earth around the base of the tree, offer protection from field mice also. They should, however, be removed in spring as they furnish retreats for hibernating insects.

Clean eultivation, the removal of brush, grass heaps, ete., will also be of eonsiderable benefit, for this lessens the number of good hiding places. 


\section{PART II.}

\section{DIAGNOSTIC CHARACTERS OF THE RODENTS.}

In this more technical part of the bulletin is included a diagnosis of the order Rodentia, following which are keys and brief diagnostic descriptions of the suborders, families, and genera in regular sequence. Tables are included also ior use in delimiting the species and subspecies of rodents known to occur, or to have occurred in the state, these tables being intended only for the Iowa representatives of the group. The page number following the specific name in the keys, refers to the general discussion of the species in part I.

\section{Order RODENTIA. Gnawing Animals.}

Incisor teeth long, strong, growing from persistent pulps, the enamel chiefly or wholly on the anterior face, producing a chisellike cutting edge; canine teeth absent; molar teeth few, and separated from the incisors by a wide diastema; toes usually with nail-like claws; feet usually plantigrade; cæcum very large; brain smooth or with few furrows, the cerebrum not overlapping the cerebellum; articular surface for lower jaw elongated antero-posteriorly; malar bone in middle of zygomatic arch ; size small to moderate; furred, some forms spined.

Key to Suborders of Rodentia.

Never more than two upper incisors ; enamel confined to anterior

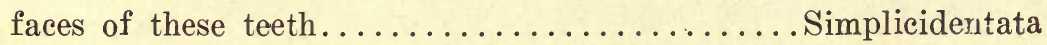

Upper incisors four in number, the second pair very small and situated immediately behind the first; enamel extending partly on sides of these teeth.................. Duplicidentata

\section{Suborder Simplicidentata.}

One pair upper incisors, the enamel confined to anterior faces; incisive foramina of palate moderate and distinct; bony palate extensive; tibia and fibula distinct, the latter not articulating with the calcaneum. 
Key to the Families of Simplieidentata.

1. Body bearing sharp, stiff spines partly concealed by hair

(6) Erethizontidæ

Body without spines.

2. Tail broad, flattened dorso-ventrally

(2) Castoridæ

Tail not broad and flattened dorso-ventrally $\ldots \ldots \ldots \ldots \ldots 3$

3. Hind legs and feet markedly elongate; tail very long

(5) Zapodidæ Hind legs, feet and tail moderate, not greatly elongate....4

4. Tail thickly haired and more or less bushy......(1) Sciuridæ Tail naked or closely or sparsely haired, not bushy.......5

5. External cheek pouches present; claws of front feet much elongated .......................4) Geomyidæ External cheek pouches wanting; claws of front feet not greatly elongated......................... Muridæ

\section{Family SCIURIDA.}

\section{SQUIRRELS, WOODCHUCKS, SPERMOPHILES, ETC.}

Tail eylindrical, bushy, with long hairs, never covered with scales; postorbital processes distinct; molar teeth rooted, tuberculate; first upper premolar small, and sometimes wanting; cheek pouches, when present, opening inside the mouth.

\section{Key to the Genera of Sciuridæ.}

1. Front and hind legs joined together by a lateral expansion of skin from sides of body............. Glaucomys Front and hind limbs not joined together by a lateral expansion of skin from sides of body $\ldots \ldots \ldots \ldots \ldots \ldots \ldots .2$

2. Length of body from nose to root of tail over 14.00

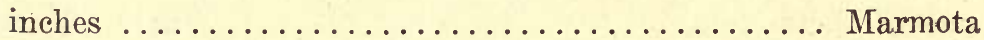
Length of body without tail iess than 14.00 inches........3

3. Tail long and bushy; cheek pouches absent or opening

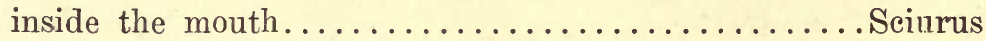
Tail moderate or short; cheek pouches present, external....4

4. Back with two pale stripes and several black ones; no

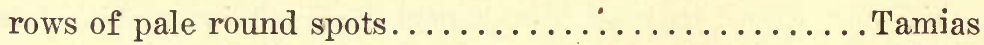
Back with or without stripes; if stripes are present, a series of pale, round spots along the middle of each dark

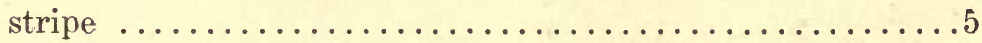


5. Thumb large, nail well developed; body thickset; no

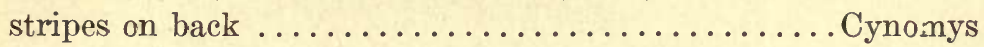
Thumb small, nail rudimentary; body rather slender; color pattern variable........................ Citlus

\section{Subfamily PTEROMYIN/E.}

Genus Glaucomys Thomas.

Fur soft and thick; legs connected by a loose skin extending out from the sides of the body ; tail depressed, thickly haired at sides ; ears large; eyes large; postorbital processes narrow, spinelike; rostrum short.

Dental formula-I. 1/1; Pm. 2/1; M. $3 / 3=22$.

A single form oceurs in Iowa.

Southern Flying Squirrel.

Glaucomys volans volans. p. 17

\section{Subfamily SCIURINE.}

Genus Sciurus Linnæus.

Tail long, broad, bushy especially at sides; eyes and ears large; five claws on front feet, the claw on thumb small, and scarcely evident; anterior upper premolar small or wanting; postorbital processes well developed, directed downward and backward; infraorbital foramen slitlike and confined to lower portion of maxillary.

Dental formula-I, $1 / 1 ; \mathrm{Pm} .2 / 1$ or $1 / 1 ; \mathrm{M} .3 / 3=22$ or 20 .

Key to Species of Sciurus.

1. General color gray; color below white or whitish.

Northern Gray Squirrel.

Sciurus carolinensis leucotis. p. 22

General color not gray; color below sometimes whitish tinged with rusty $\ldots \ldots \ldots \ldots \ldots \ldots \ldots \ldots \ldots \ldots \ldots \ldots \ldots \ldots \ldots \ldots \ldots \ldots$

2. Total length 21.00 to 23.00 inches; general color more or less tawny brown.

Western Fox Squirrel.

Sciurus niger rufiventer. p. 19

Total length 12.00 to 15.50 inches; general color reddish brown.

Red Squirrel.

Sciurus hudsonicus loquax. p. 25 


\section{Genus Tamias Illiger.}

Back conspicuously striped; tail short, not bushy; cheek pouches large; postorbital processes slender, pointed, directed obliquely backward and downward; infraorbital foramen oval, confined to lower part of maxilla.

\section{Dental formula-I, 1/1; Pm. 1/1. M. $3 / 3=20$.}

Key to Species of Tamias.

Back with two whitish stripes, and five black ones; chestnut rufous on rump; total length, about 9.60 inches.

Chipmunk.

Tamias striatus striatus, p. 26

Similar to above, but grayer and largen; rump cinnamon browil; total length, about 10.25 inches.

Gray Chipmunk.

Tamias striatus griseus. p. 27

\section{Subfamily MARMOTINE.}

Genus Citellus Oken.

Body rather slender; tail variable in length, but not bushy; ears variable, but not tufted; cheek pouches large; front feet with four well developed toes, the thumb rudimentary; hind feet with five toes; postorbital processes slender and spinelike; anteorbital foramen circular, a tubercle on lower outer edge; two upper premolars, the first much smaller than the second.

Dental formula-I. $1 / 1$; Pm. $2 / 1$; M. $3 / 3=22$.

Key to Species of Citellus.

Color grayish brown, not striped; total length, about 15.00 inches.

Franklin's Spermophile.

Citellus franklini. p. 36

Back with seven yellowish white lines, which alternate with six rows of rounded, yellowish white spots in a brown background; total length, 10.50 inches.

Thirteen-lined Spermophile. 


\section{Genus Cynomys Rafinesque.}

Body unmarked, not sharply bicolor; pelage short; tail short, flat; ears rudimentary; cheẹ pouches shallow; wrist and heel heavily furred; fect with claws on all five toes, the thumb large, and the nail well developed; postorbital processes strong, decurved; infraorbital foramen large, subtriangular; molar series divergent anteriorly, the teeth large, and expanded laterally; first premolar large.

Dental formula-I. 1/1; Pm. $2 / 1 ;$ M. $3 / 3=22$.

A single form occurs in Iowa.

Black-tailed Prairie-dog.

Cynomys ludovicianus ludovicianus. p. 40

Genus Marmota Blumenback.

Size large, legs short; tail short, thickly haired; front feet with four well developed tces, the thumb rudimentary and with a flat nail; hind feet with five tces; skull heavy, flattened above; postorbital processes broad at base, stout, decurved, at right angles to long axis of skull; first premolar nearly as large as second; molar series with two transverse grooves across their crowns; nearly parallel.

Dental formula-I. 1/1; Pm. 2/1; M. $3 / 3=22$.

A single form oceurs in Iowa.

Southern Woodchuck.

Marmota monax monax. p. 45

\section{Family CASTORIDE.}

BEAVERS.

Tail broad and flattened, hairless and eovered with seales; five toes on both fore and hind feet, the latter broadly webbed; seennd toe of hind foot with double claw; skull stout, without postortital processes; infraorbital foramen nearly concealed by a large, almost vertical ridge on the maxilla; incisors large, powerful, the lower much longer than the upper, and the anterior surface deep orangered in color; molars single-rooted with re-entering enamel folds, and decreasing in size posteriorly; molar series converging anteriorly; palate arehed and contracted anteriorly. 
Genus Castor Linnæus.

In addition to the family characters above mentioned, the following may be included here, since but a single genus is recognized: Upper molars subequal, with one inner and two outer enamel folds; molars with dentinal pulp persisting until late in life; teeth of molar series not parallel but converging anteriorly.

Dental formula-I. 1/1; Pm. 1/1, M. 3/3=20.

A single form has occurred in Iowa.

Beaver.

Castor canadensis canadensis. p. 50

\section{Family MURIDA.}

\section{RATS AND MICE.}

Lower incisors compressed; premolars wanting; molars never more than three in each jaw, with or without roots, tuberculate or with enamel folds; frontals contracted; infraorbital foramen wider above than below; jugal splintlike; postorbital processes wanting; tibia and fibula anchylosed below.

Key to the Genera of Muridæ.

1. Total length 10.00 inches or over................ 6

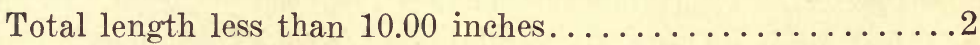

2. Front of upper incisors with longitudinal groove.......... Front of upper incisors without longitudinal groove......4

3. Superior incisors with a deep longitudinal groove nearly as broad as the face of the tooth.........Reithrodontomys Superior incisors longitudinally grooved on outer edges

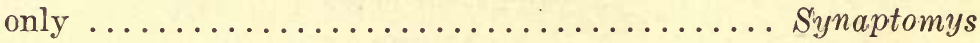

4. Tail short; length of tail vertebræ usually not over 2.00 inches; form short; ears short ..............Microtus Tail longer; length of tail vertebræ over 2.00 inches; form

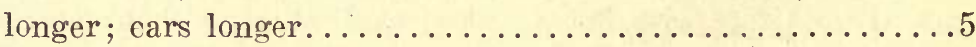

5. Molars of upper jaw with tubercles on crowrs extending

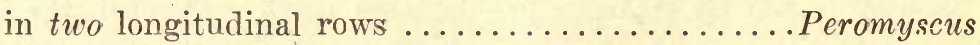
Molars of upper jaw with tubercles on erowns extending

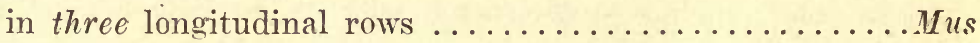

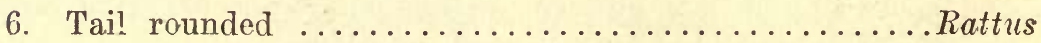
Tail laterally compressed.................... Fiber 


\section{Subfamily MURINE.}

\section{Genus Mus Linnæus.}

Three molars in upper jaw, the tubercles on the crowns arranged in three longitudinal rows; crown of anterior molar larger than both the others combined; third molar very small; fore feet with four developed toes and a rudimentary thumb with a short nail; five developed toes on hind feet; ears large, prominent; nose acute; tail long, usually nearly naked and scaly.

Dental formula-1. 1/1; M. $3 / 3=16$.

A single form occurs in Iowa and the United States.

House Mouse.

Mus musculus. p. 52

Genus Rattus G. Fisher.

Premolars wanting; upper molars with tubercles on! crowns arranged in three longitudinal rows; "molars slightly graduated in size from first to third, the anterior tooth not tending to assume the main function of the tooth row, the posterior tooth not tending to disappear, enamel folding of upper molars directly referable to a simple 9-cusped pattern and its reductions, the outer margins of $\mathrm{M}^{1}$ and $\mathrm{M}^{2}$ never with more than 3 cusps, the inner margin of same teeth never with more than 2 cusps, $\mathbf{M}^{1}$ usually with 5 roots, its first lamina not distorted by the backward displacement of the antero-internal tubercle; upper incisor muderately compressed, set at such an angle that its outer side is worn smoothly away by action of lower teeth.", ${ }_{37}$

\section{Dental formula-I. $1 / 1 ;$ M. $3 / 3=16$.}

Key to Species of Rattus.

Ears moderate; length of tail usually less than length of head and body; color grayish brown above, white below; hind foot, 38 to $46 \mathrm{~mm}$.

Brown Rat.

Rattus norvegicus. p. 54

Ears larger, broader; tail longer than head and body; entire pelage dusky in color; hind foot, 33 to $37 \mathrm{~mm}$. (Probably not now occurring within our limits.)

Black Rat.

Rattus rattus. p. 68

${ }^{37}$ Miller, G. S., Proc. Biol. Soc. Wàsh., XXIII, 58, 1910. 


\section{Subfamily CRICETINAE.}

\section{Genus Peromyscus Gloger.}

Unworn molars with a double series of conical tubercles which become worn by abrasion, resulting in a constantly changing pattern; molar series short, narrow, the teeth decreasing in size from front to back; size moderate, face long, nose pointed; ears thin, rounded; feet small, the palms naked, the soles of hind feet with five or six tubercles; tail slender, haired, at least two inches long; belly white or whitish; pelage soft, often glossy.

Dental formula-I. $1 / 1$; M. $3 / 3=16$.

Key to Species of Peromyscus.

Tail vertebræ less than 2.75 inches; tail sharply bicolor; general color brown mixed with black; total length, 5.50 to 6.50 inches. Prairie White-footed Mouse.

Peromyscus maniculatus bairdi. p. 73

Tail vertebræ more than 2.75 inches; tail not sharply bicolor; general color brown, darker alorig middle of back; total length, about 7.00 inches.

\section{Northern White-footed Mouse.}

Peromyscus leucopus noveboracensis. p. 69 Genus Reithrodontomys Giglioli.

Body slender; size very small; tail long, more than one-third total length, scaly, slender, and sparsely haired; ears prominent; soles of feet with six tubercles; no cheek pouches; upper incisors with a deep longitudinal groove nearly as broad as the face of the tooth; lower incisors simple; molars with the tubercles arranged in two longitudinal series; first upper molar with five principal tubercles; posterior border of palate square, terminating opposite posterior border of last molars; outer wall of anteorbital foramen a broad thin plate.

Dental formula-I. $1 / 1$; M. $3 / 3=16$.

A single form occurs in Iowa.

Prairie Harvest Mouse.

Reithrodontomys megalotis dychei. p. 76

\section{Subfamily MICROTINAE.}

Genus Microtus Schrank.

Form short, thickset; tail, lers and muzzle short; ears short, buried in the fur; upper incisors not grooved; root of lower in- 
cisor extending back to third molar, displacing the base of that tooth; molars not rooted, the crowns with irregular triangles or loops; soles of feet with four to :ix tubercles.

\section{Dental formula-I. $1 / 1 ;$ M. $3 / 3=-16$.}

Key to Species of Microtus.

1. Total length more than 5.50 inches; tail vertebræ more

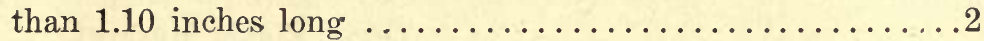
Total length less than 5.50 inches; tail vertebræ 1.00 inch or less long; upper parts dull chestnut; under parts plumbeous tinged with cinnamon rufous; mammæ 4

\section{Woodland Vole.}

Microtus pinetorum nemoralis. p. 91

2. Tail usually less than 1.60 inches long; five tubercles on soles of feet; upper parts mixed light and dark brown; under parts buffy gray; or pale brownish gray; mammæ 6

Prairie Meadow Mouse. Microtus ochrogaster ochrogaster. p. 87

Tail usually more than 1.60 inches long; six tubercles on soles of feet; upper parts brownish, but withcut the "grizzled" appearance of $M$. o. ochrogaster; under parts grayish white, sometimes tinged with brown; mammæ 8 .

Meadow Mouse.

Microtus pennsylvanicus pennsylvanicus. p. 78

\section{Genus Fiber Cuvier.}

Size large, form stout; legs short, feet large and modified for swimming; toes of hind feet partly webbed; tail long, vertically compressed, covered by thin scales, and scantily haired; external ears small, almost hidden in the fur, which is dense and waterproof; a series of long, glossy overlying hairs intermingled with the shorter pelage; well developed perineal glands secreting a strong odor; mammæ 6; five tubercles on soles of feet; upper incisors without grooves; molars rooted; auditory bullæ large, the edges protruding. 


\section{Dental formula-I. $1 / 1 ;$ M. $3 / 3=16$.}

Key to Subspecies of Fiber.

Size large; hind foot averaging over $80 \mathrm{~mm}$; color dark brown.

Common Muskrat.

Fiber zibethicus zibethicus. p. 96

Size smaller; hind frot less than $80 \mathrm{~mm}$.; color reddish or pale brown.

Great Plains Muskrat.

Fiber zibethicus cinnamominus. p. 105

Genus Synaptomys Baird.

Front of upper incisors with a distinct longitudinal groove near outer edges; root of lower incisor ending abruptly opposite last lower molar; crowns of molars with transverse loops; teeth of molar series strongly convergent anteriorly, the individual teeth large; ears equal to or longer than the fur; tail equal to or longer than hind foot; pelage dense and soft.

Dental formula-I. $1 / 1$; M. $3 / 3=16$.

A single form occurs in Iowa.

Goss' Lemming Mouse.

Synaptomys cooperi gossii. p. 106

\section{Family GEOMYIDAE.}

\section{POCKET GOPHERS.}

Form short, heavy; large, external, fur-lined cheek pouches opening outside the mouth; feet fossorial, the front pair being particularly well developed; eyes and ears minute; tail thick, fleshy, usually hairless; molars rootless.

Genus Geomys Rafinesque.

Upper incisors furnished with two longitudinal grooves, a broad, deep one along the middle, and a smaller and narrower one along the inner edge; crowns of teeth of molar series with transverse enamel loops, a single loop on each molar, two loops on the premolar; infraorbital foramen confined to lower portion of maxilla; auditory meatus tubular, elongated.

Dental formula-I. 1/1; Pm. 1/1; M. 3/3=20.

A single form occurs in Iowa.

Pocket Gopher.

Geomys bursarius bursarius. p. 108 


\section{Family ZAPODIDE.}

\section{JUMPING MICE.}

Body enlarged posteriorly; hind legs and tail much elongated, the latter greatly exceeding the trunk in length, very slender and scantily haired; fore legs short; upper incisors compressed and sulcate; molars rooted; anteorbital foramen large, with an additional notch or foramen at its lower portion.

\section{Subfamily ZAPODINAE.}

\section{Genus Zapus Coues.}

Internal cheek pouches present, small; first digit of fore foot rudimentary, nail flat and blunt; hind foot with five toes, each with separate metatarsal; anteorbital foramen large, obliquely oval; upper incisors short, stout, grooved; orange brown in color; upper premolar present, small; crowns of molars with complex enamel folds; pelage coarse.

Dental formula-I. $1 / 1$; Pm. 1/0; M. 3/3=18.

Key to Subspecies of Zapus.

Color above tawny to yellowish brown; total length, 8.00 inches. Hudson Bay Jumping Mouse.

Zapus hudsonius hudsonius. p. 122

Color above paler; total length, 8.75 inches.

Prairie Jumping Mouse.

Zapus hudsonius campestris. p. 124

\section{Family ERETHIZONTIDE.}

\section{AMERICAN PORCUPINES.}

Form short, stout; body more or less covered with sharp, stiff quills which are loosely attached to the skin; molars more or less completely rooted; facial portion of skull short, the jugal lacking the inferior angle.

\section{Subfamily ERETHIZONTINA.}

Genus Erethizon F. Cuvier.

Body covered with hairs intermingled with loosely attached quills or spines on back and sides; tail short, thick, non-prehensile, covered above with stiff hairs and spines, below and on sides with stiff bristles; limbs short, strong; four toes in front and 
five behind, all armed with strong, curved claws; ears short; anteorbital vacuity very large; crowns of molars with enamel folds and more or less completely rooted; mammæ four, all pectoral.

Dental formula-I. $1 / 1$; Pm. $1 / 1$; M. $3 / 3=20$.

A single form possibly occurs in Iowa.

Canada Porcupine.

Erethizon dorsatum dorsatum. p. 126

\section{Suborder Duplicidentata.}

Two pairs permanent upper incisors, the second very small and placed immediately behind the others; at birth three pairs of incisors are present but the outer one on each side is soon lost; enamel of incisors continuous and not confined to anterior faces of teeth; incisive foramina of palate large and usually confluent; bony palate narrow from before backwards; tibia and fibula united and articulating with the calcaneum.

This suborder is made up of two families, the Leporidæ, eontaining the true hares and rabbits, and the Ochotonidæ, containing the chief hares. These latter are small animals occurring in the mountainous regions af western North America, and do not oscur in Iowa.

\section{Family LEPORIDE.}

\section{HARES AND RABBITS.}

Hind legs greatly elongated; tail short, bushy; soles of feet covered with fur; eyes large; upper lip deeply cleft; cheek pouches wanting but inside of mouth partly furry; skull flat; facial surface of maxilla perforated; palate narrow; rami of mandible flat; clavicles imperfect.

\section{Key to the Genera of Leporidæ.}

Interparietal not distinct in adult; supraorbital process usually more or less expanded and subtriangular, usually somewhat divergent from skull; hind foot five or more inches long........ Lepus

Interparietal distinct in adult; supraorbital processes narrower, . the posterior notch usually narrower or wanting, owing to union of postorbital process with skull; hind foot about four inches

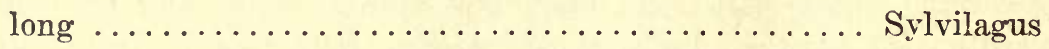




\section{Genus Lepus Linnæus.}

Interparietal not distinct in adults; supraorbital usually broadly expanded, subtriangular in outline; second to fifth cervical vertebræ longer than broad; median carina on dorsal surface; hind foot, in our forms, five inches or over.

\section{Dental formula-I. $2 / 1$; Pm. $3 / 2$; M. 3/3=28.}

Key to Species of Lepus.

1. Length of ear from skull to tip less than 3.75 inches; total length 17.50 to 18.50 inches; hind foot five inches or more.

Minnesota Varying Hare.

Lepus americanus phaeonotus. p. 130

Length of ear from tip to skull 3.75 inches or more;

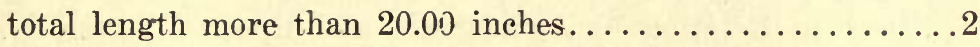

2. Tail entirely white above and below; rump whitish in winter, similar to rest of back in summer; total length, 24.00 inches.

White-tailed Jack Rabbit.

Lepus townsendi campanius. p. 131

Tail whitish below, the upper side marked with a blackish band extending backward from rump; rump patch large, gray; total length, 23.00 inches.

Great Plains Jack Rabbit.

Lepus californicus melanotis. p. 133

Genus Sylvilagus Gray.

Interparietal distinet in adult; supraorbital prominent, the postorbital process more slender and pointed than in Lepus; posterior notch usually narrowed or obliterated on account of union of postorbital with skull; second to fourth cervical vertebræ broader than long; no carina on dorsal surface; one annual molt; hind foot, in our representative, about four inches.

Dental formula-I. $2 / 1$; Pm. $3 / 2 ;$ M. $3 / 3=28$.

A single form occurs in Iowa.

Mearns' Cottontail. Sylvilagus floridanus mearnsi. p. 134 


\section{List of References.}

The following list of books and papers is arranged alphabetically by authors, and is intended to provide a series of suitable working references; some are general and some apply particularly to the Iowa fauna. Other, and more complete reference tables and bibliographies will be found in the various volumes herein listed.

Allen, J. A., Notes on the Mammals of Iowa, Proc. Boston Soc. Nat. Hist., XIII, 178-194, 1869 (1871).

Bailey, Vernon, The Pocket Gophers of the United States, U. S. Dept. Agr., Bull. No. 5, 1895.

Beddard, F. F., Mammalia, Cambridge Nat. Hist., X, 458-507, 1909. Bell, W. B., and Piper, Stanley E., Extermination of Ground Squirrels, Gophers and Prairie Dogs in North Dakota, N. Dak. Agr. Exp. Sta., Circ. 4, 1915.

Birdseye, Clarence, Some Common Mammals of Western Montana in Relation to Agriculture and Spotted Fever, U. S. Dept. Agr., Farmers' Bull. 484, 1912.

Cory, Charles B., The Mammals of Illinois and Wisconsin, Field Mus. Nat. Hist., Pub. 153, Zool. Series, XI, 1912.

Coues, Elliott, and Allen, J. A., Monographs of North American Rodentia, Rept. U. S. Geol. Surv. Terr., F. V. Hayden, XI, 1877.

Elliott, Daniel Giraud, A Synopsis of the Mammals of North America and the Adjacent Seas, Pub. Field Mus. Nat. Hist., Zool. Series, II, 1901.

Flower, W. H., An Introduction to the Osteology of the Mammalia, 1885.

Flower, W. H., and Lydekker, R., An Introduction to the Study of Mammals Living and Extinct, 443-495, 1891.

Goldman, Edward A., The Rire Rats of North America (Genus Oryzomp), N. A. Fauna No. 43, 1918.

Herrick, C. L., The Mammals of Minnesota, Geol. and Nat. Hist. Surv. Minn., Bull. No. 7, 1892.

Hollister, N., A Systematic Synopsis of the Muskrats, N. A. Fauna, No. 32, 1911.

Hollister, N., A Systematic Account of the Prairie-dogs, N. A. Fauna, No. 40, 1916.

Howell, A. H., Revision of the American Harvest Mice, N. A. Fauna, No. 36, 1914.

Howell, A. H., Revision of the American Marmots, N. A. Fauna, No. 37, 1915. 
Howell, A. H., Revision of the American Flying Squirrels, N. A. Fauna, No. 44, 1918.

Lantz, D. E., Meadow Mice in Relation to Agriculture and Horticulture, Yearbook U. S. Dept. Agr., 1905, 363-376.

Lantz, D. E., An Economic Study of Field Mice, U. S. Dept. Agr., Biol. Surv., Bull. No. 31, 1907.

Lantz, D. E., Methods of Destroying Rats, U. S. Dept. Agr., Farmers' Bull. No. 297, 1907.

Lantz, D. E., Use of Poisons for Destroying Noxious Animals, Yearbook U. S. Dept. Agr., 1908, 421-432.

Lantz, D. E., Pocket Gophers as Enemies of Trees, Yearbook U. S. Dept. Agr., 1909, 209-218 (3 pl.).

Lantz, D. E., How to Destroy Rats, U. S. Dept. Agr., Farmers' Bull. No. 369, 1909.

Lantz, D. E., The Muskrat, U. S. Dept. Agr., Farmers' Bull. No. 396, 1910.

Lantz, D. E., The Muskrat as a Fur Bearer, U. S. Dept. Agr., Farmers' Bull. No. 869, 1.917.

Lantz, D. E., House Rats and Mice, U. S. Dept. Agr., Farmers' Bull. No. 896, 1917.

Miller, G. S., Genera and Subgenera of Voles and Lemmings, N. A. Fauna, No. 12, 1896.

Morgan, L. H., The American Beaver and His Works, 1868.

Nelson, E. W., The Rabbits of North America, N. A. Fauna, No. 29, 1909.

Nutting, C. C., Report of the Committee on State Fauna, Proc. Ia. Acad. Sci., II, 43-44, 1894.

Osborn, H., Catalogue of the Mammals of Iowa, Proc. Ia. Acad. Sci., 1887-1889, 41-44, (1890).

Osborn, H., A partial Catalogue of the Animals of Iowa, Ames, Ia., 5, 1891.

Osgood, W. H., Revision of the Mice of the American Genus Peromyseus, N. A. Fauna, No. 28, 1909.

Preble, E. A., Revision of the Jumping Mice of the Genus Zapus, N. A. Fauna, No. 15, 1899.

Quick, E. R., and Butler, A. W., The Habits of Some Arvicolinæ, Am. Nat., XIX, No. 2; 113-118, 1885.

Ruthven, A. G., and Wood, N. A., Notes on a Collection of Mammals from Northwestern Iowa, Proc. Ia. Acad. Sci., XIX, 203-205, 1912. 
Stoner, Dayton, Notes on Some Iowa Rodents, Proc. Ia. Acad. Sci., XXIV, 353-356, 1917.

Van Hyning, T., and Pellett, Frank C., An Annotated Catalogue of the Recent Mammals of Iowa, Proc. Ia. Acad. Sci., XVII, 211-218, 1910.

Van Hyning, T., Additional Mammal Notes, Proc. Ia. Acad. Sci, XX, 311-312, 1913.

Various Authors, The Rat and Its Relation to the Public Health, Treasury Dept., Public Health and Marine-Hospital Service of U. S., 1910. 


\section{INDEX}

$\mathbf{A}$

Adams county, bounties in ..............................117

Algona, Franklin's spermophile at........................ 38

Allamakee county, bounties in...........................117

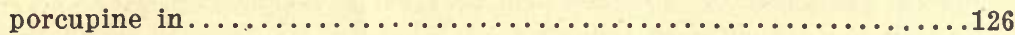

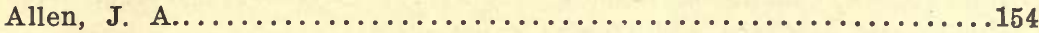

Alter, J. K....................................... 15

American porcupine................................. 151

Appanoose county, bounties in............................117

Arctomys franklinii...................................... 36

Arctomys ludoviciana................................... 40

Arsenic as poison.......................................66

Atlantic, meadow mouse at............................. 81

prairie harvest mouse at............................. 78

prairie meadow mouse at............................ 91

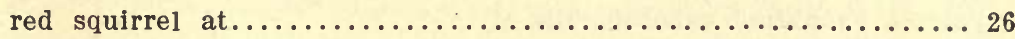

woodchuck at..................................... 46

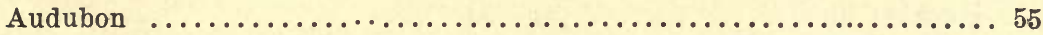

B

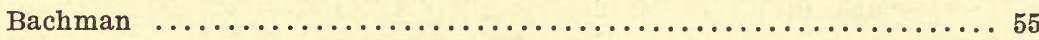

Badgers, enemies of rodents..................... 33, 42, 115

Bailey, B. H................................ 15, 124

Bailey, Vernon................................ 32,154

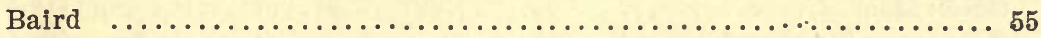

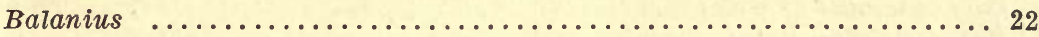

Barium carbonate as poison.......................... 65,87

Barn owls, enemies of rodents................... 33, 85, 115

Barred owls, enemies of rodents..................... 85, 137

Barrel trap.......................................... 64

Bayfield, northern white-footed mouse at................... 71

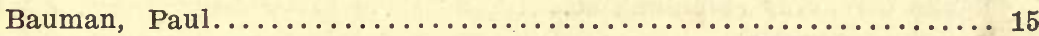

Bearden, Virgil ..................................... 15

Beavers ................................... 145, 146

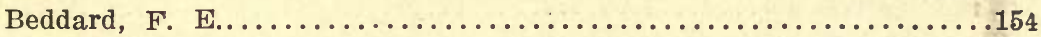

Bell, W. B........................................ 154

Benton county, bounties in..............................117

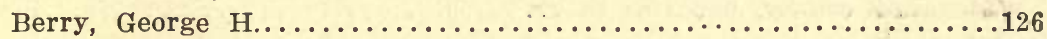

Biological Survey, Bureau of..........54, 62, 63, 64, 72, 92, 120, 135, 136

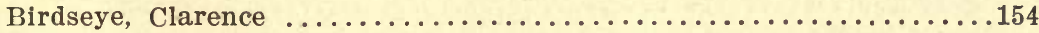

Bitterns, enemies of rodents....................... 76,85

Black-footed ferrets, enemies of rodents..................... 42

Black rat..........................................147 


\section{INDE.X}

Black-tailed prairie dog........................ 40, 145

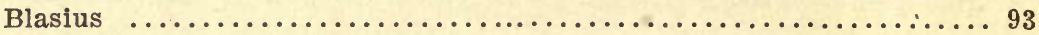

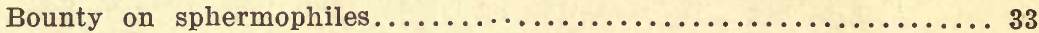

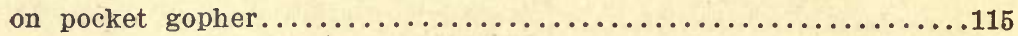

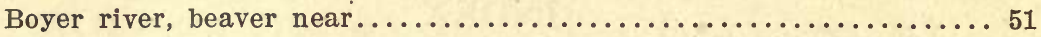

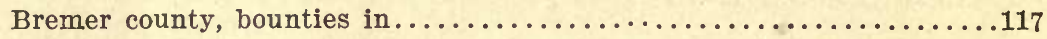

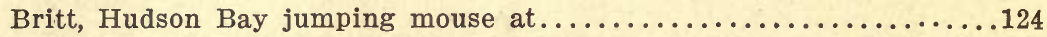

Broad-winged hawks, enemies to rodents..................... 85

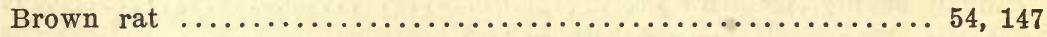

Broad-winged hawks, enemiest of rodents................... 85

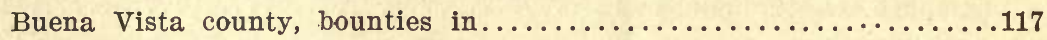

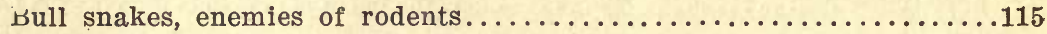

Burlington, northern white-footed mouse at................ 71

Butler, A. W........................... 155

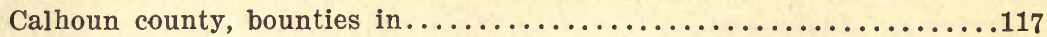

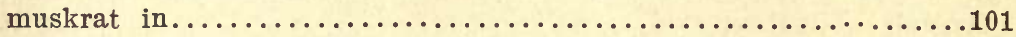

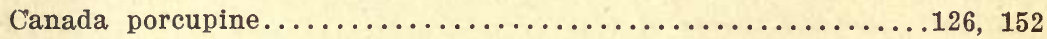

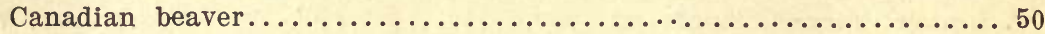

Carbon bisulphide as poison.......................... 66

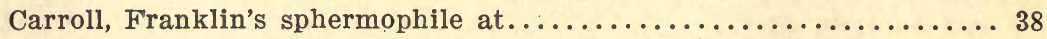

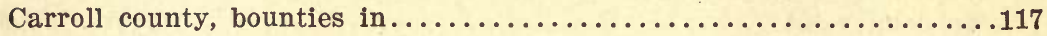

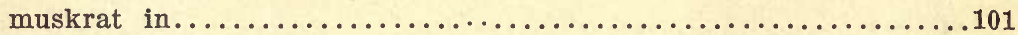

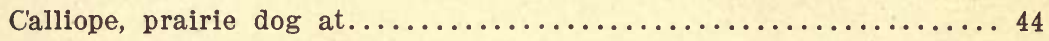

Cass county, prairie dog in........................ 44

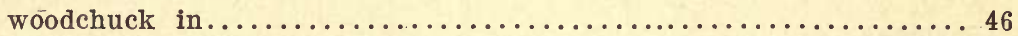

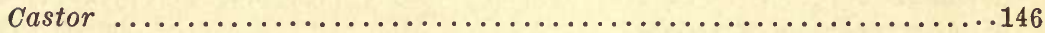

canadensis canadensis............................. 146

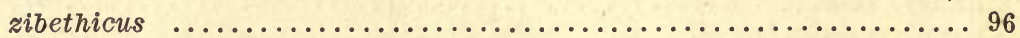

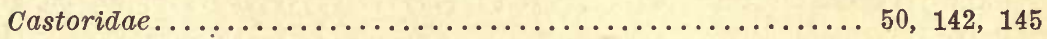

Cats, enemies of rodents............................. 137

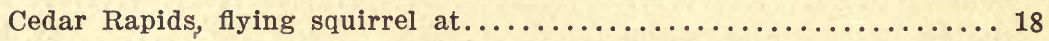

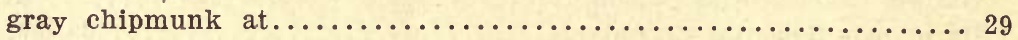

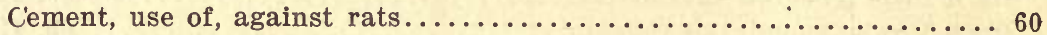

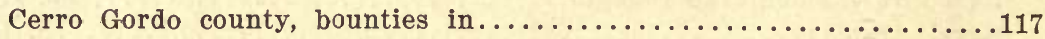

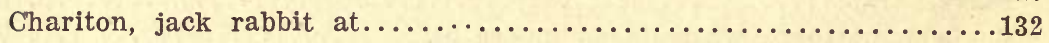

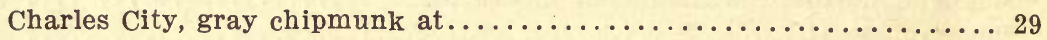

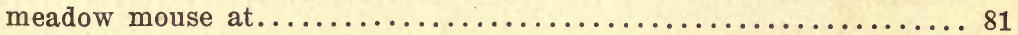

northern white-footed mouse at........................ 71

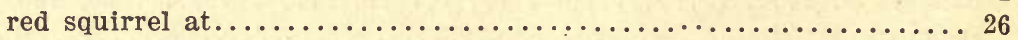

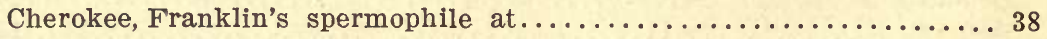

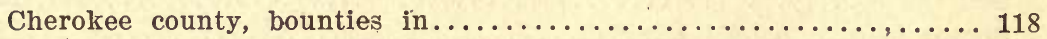

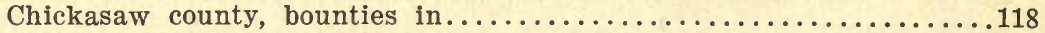

Chipmunk................................. 144

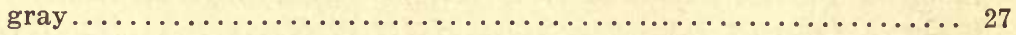

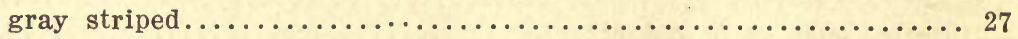

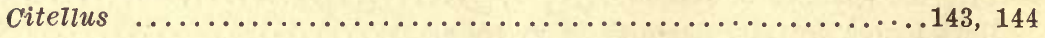

Franklini .................................. 144 
tridecemlineatus tridecemlineatus................. 29, 144

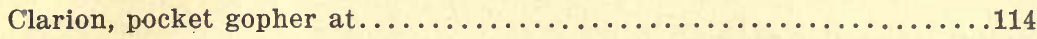

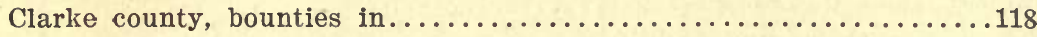

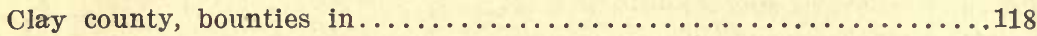

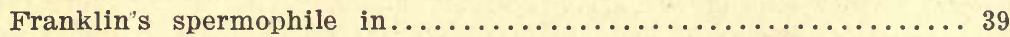

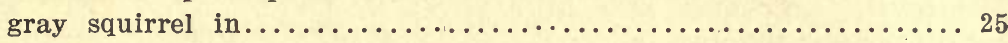

northern white-footed mouse from ....................... 71

prairie white-footed mouse in ................... 74,76

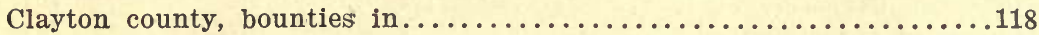

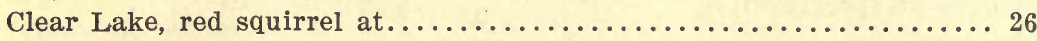

Cooper's hawks, enemies of rodents................. 33, 137

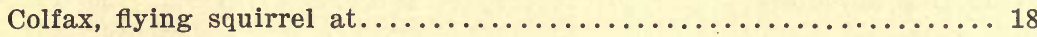

Cory, Charles B....................... 46, 97, 125, 154

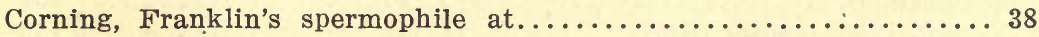

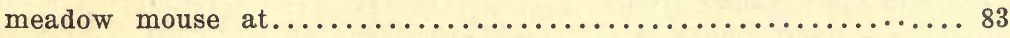

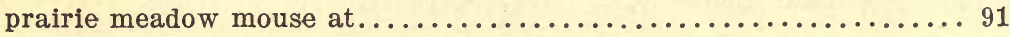

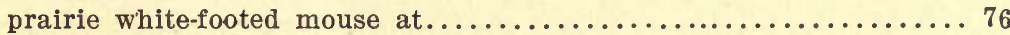

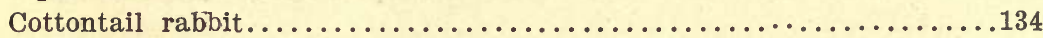

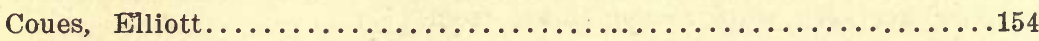

Council Bluffs, northern white-footed mouse at.............. 71

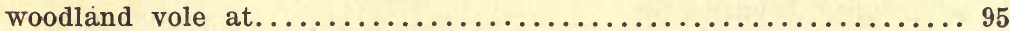

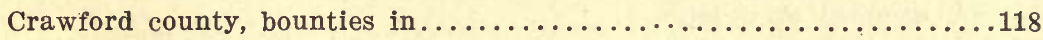

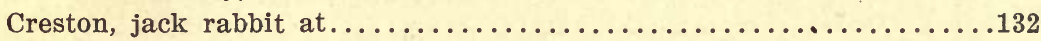

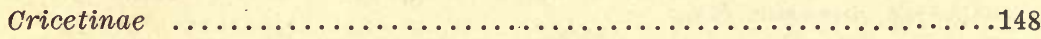

Crows, enemies of rodents..................... 85

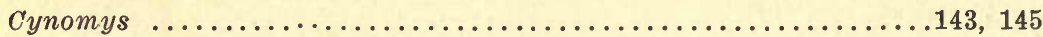

ludovicianus ludovicianus..................... 40, 145

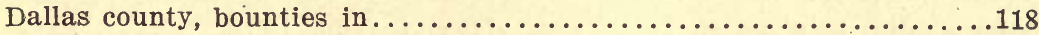

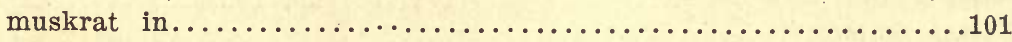

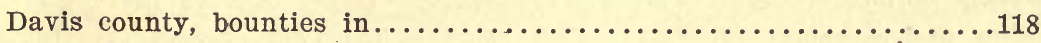

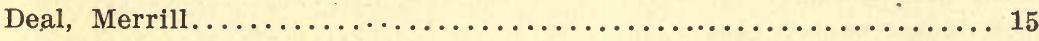

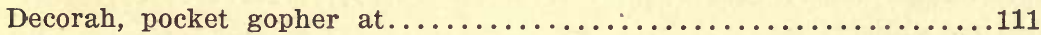

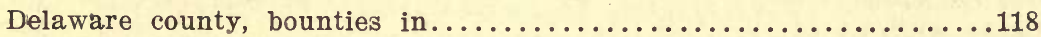

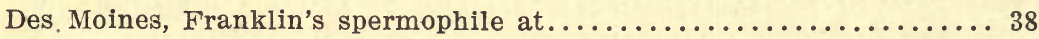

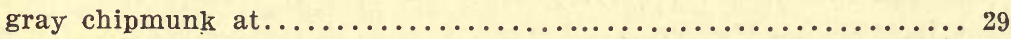

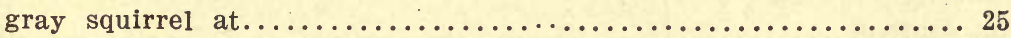

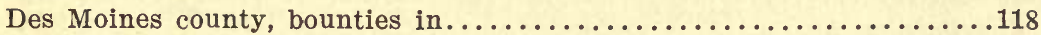

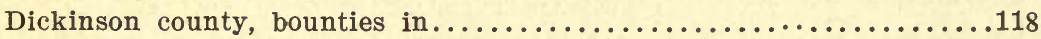

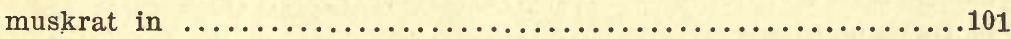

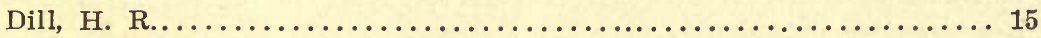

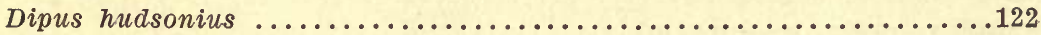

Dogs, enemies of rodents.......................60, 137

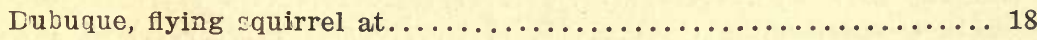

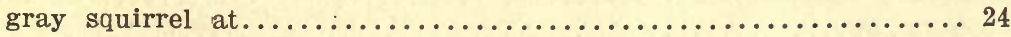

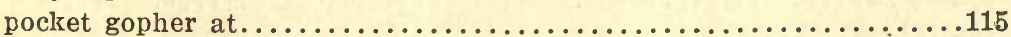

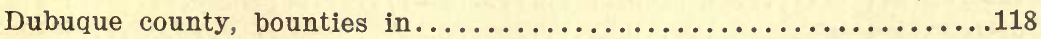

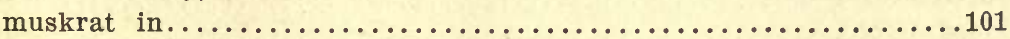

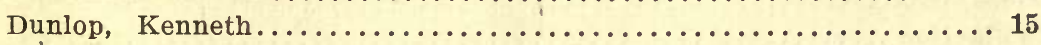

Duplicidentata .................................... 152 


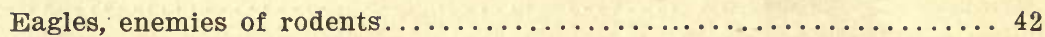

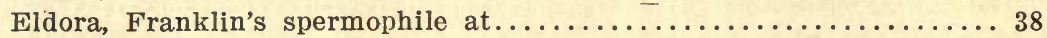

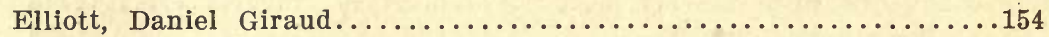

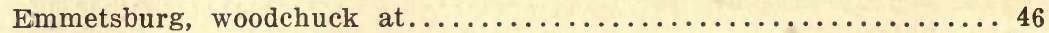

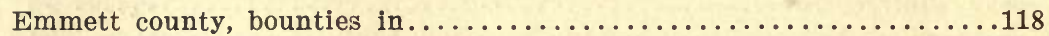

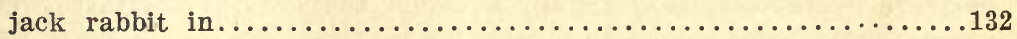

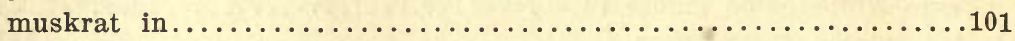

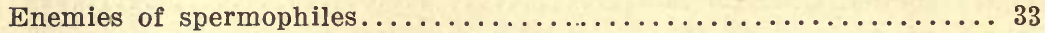

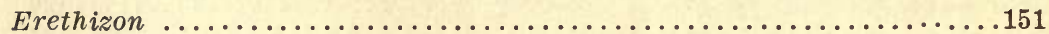

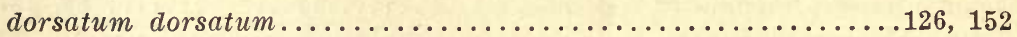

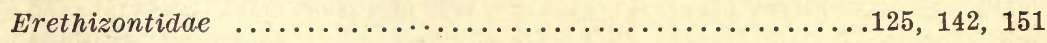

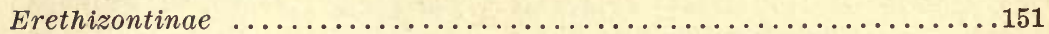

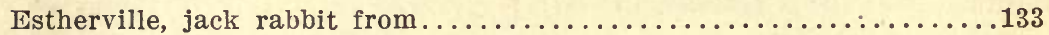

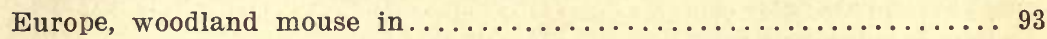

Fairport, northern white-footed mouse from................. 71

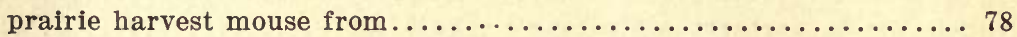

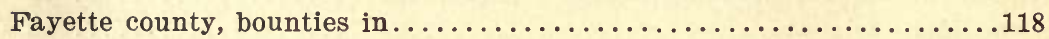

Ferrets, enemies of rodents....................... 60

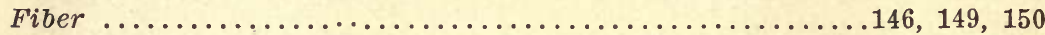

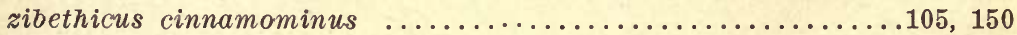

zibethicus zibethicus ....................... 96, 150

Field, Henry............................ 61, 129

Field Museum of Natural History..................... 47

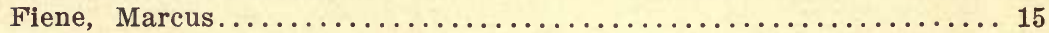

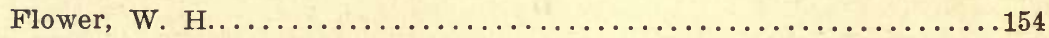

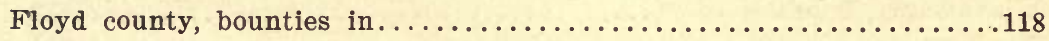

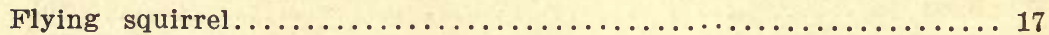

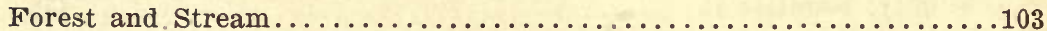

Fort Dodge, beaver near.............................. 51

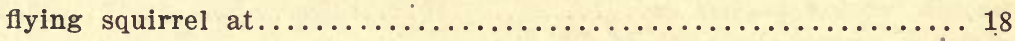

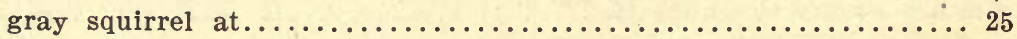

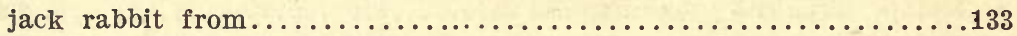

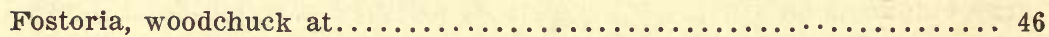

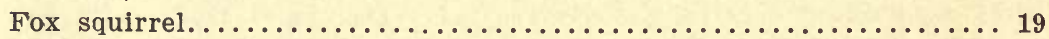

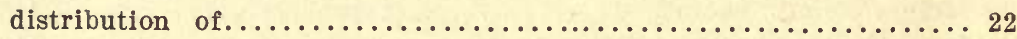

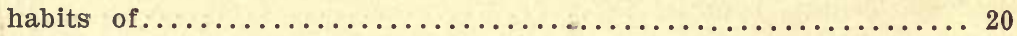

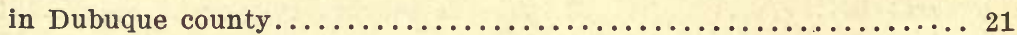

Foxes, enemies of rodents............................. 137

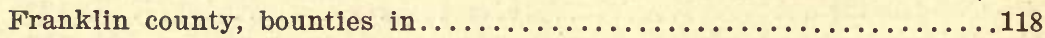

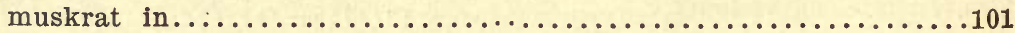

Franklin"s spermophile............................... 144

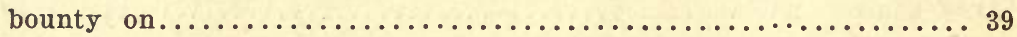

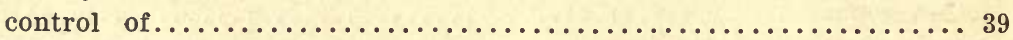

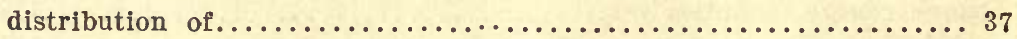

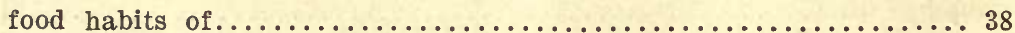

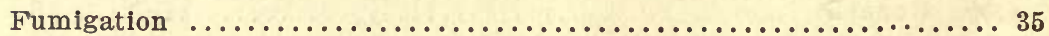




\section{G}

Geomyidae

Geomys

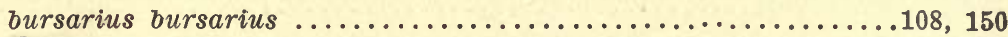

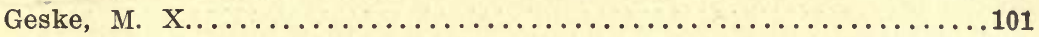

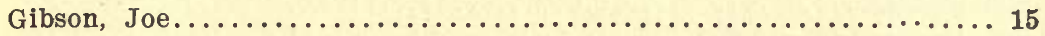

Gilmore, Franklin's spermophile at..................... 38

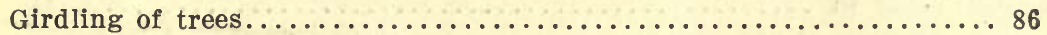

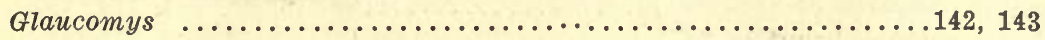

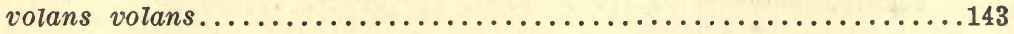

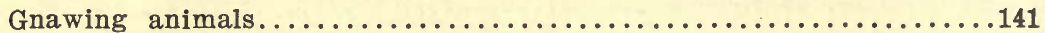

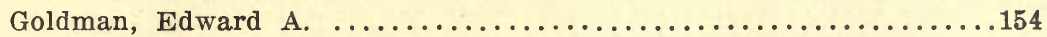

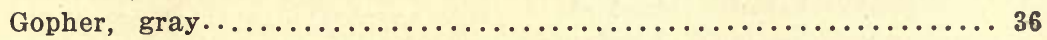

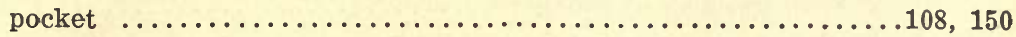

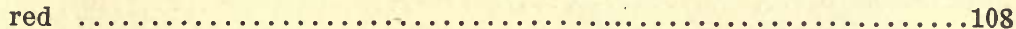

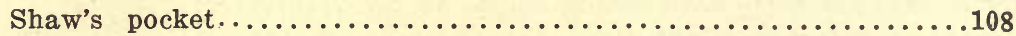

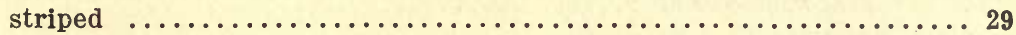

Goss' lemming mouse............................... 150

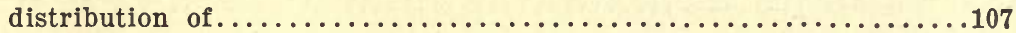

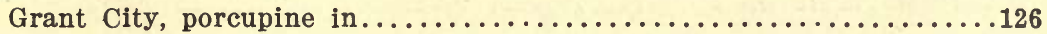

Gray chipmunk................................ 144

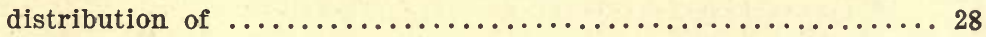

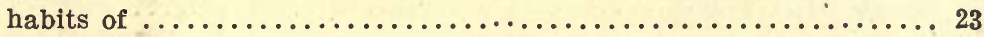

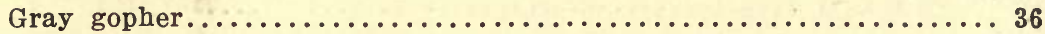

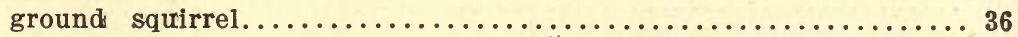

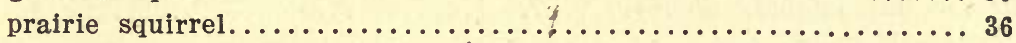

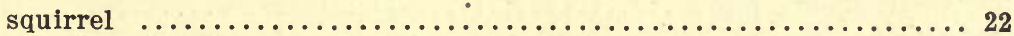

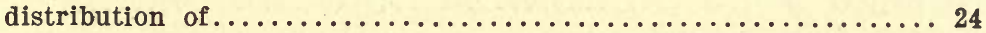

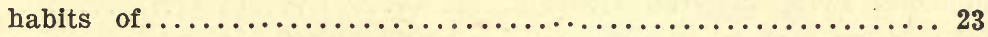

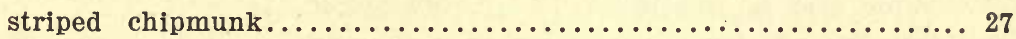

Great horned owls, enemies of rodents.................. 33, 137

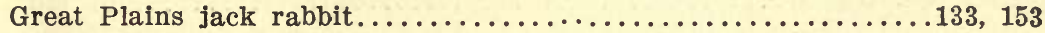

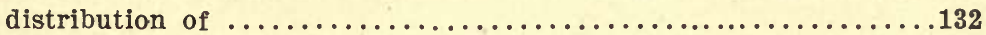

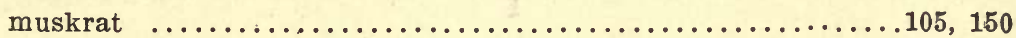

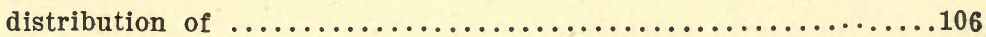

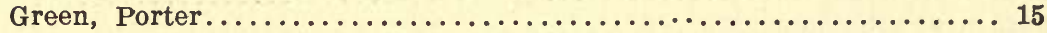

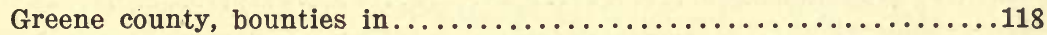

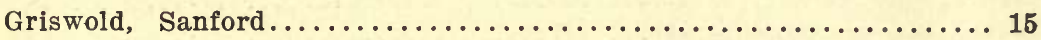

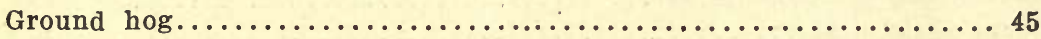

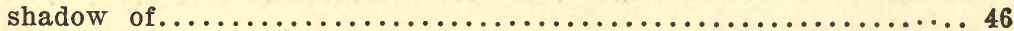

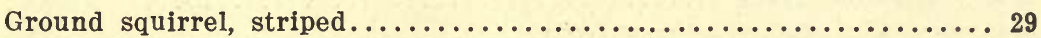

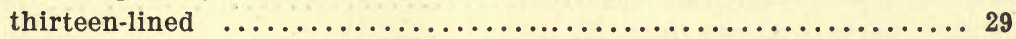

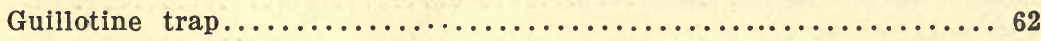

Gwynn, Mr. ................................. 129, 132

II

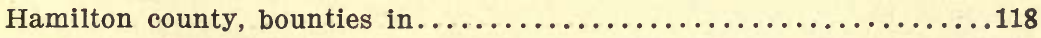

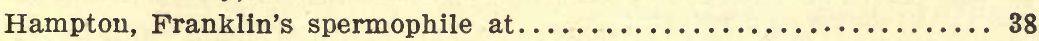

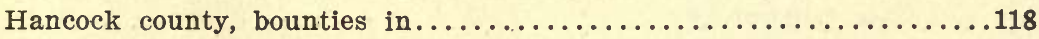

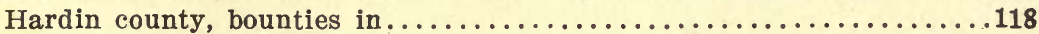




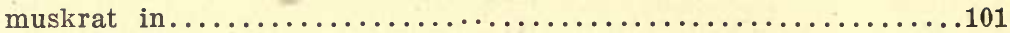

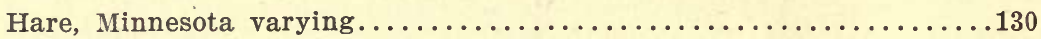

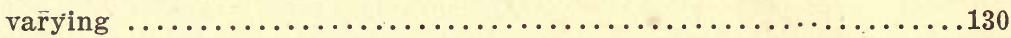

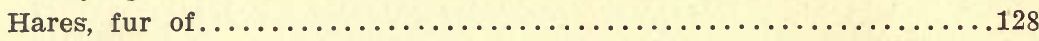

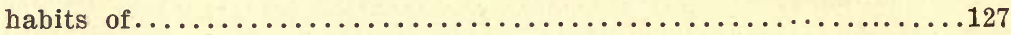

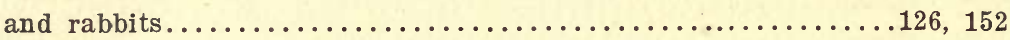

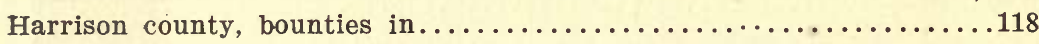

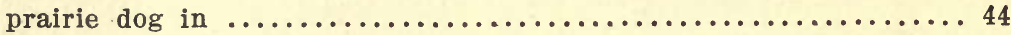

Hawks, enemies of rodents..............

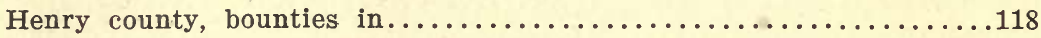

Herons, enemies of rodents.................... 85

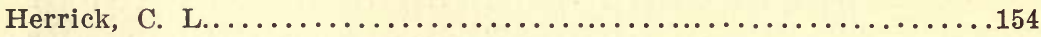

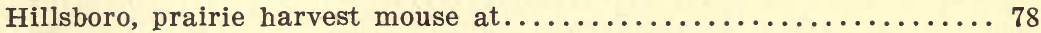

Hog-nosed snakes, enemies of rodents........................

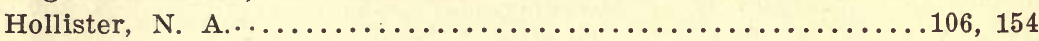

Homestead, northern white-footed mouse at................ 71

prairie meadow mouse at............................. 91

prairie white-footed mouse at........................ 76

House mouse................................. 147

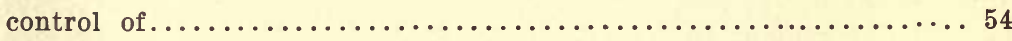

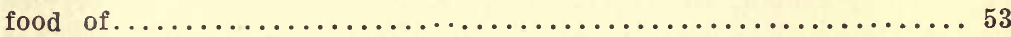

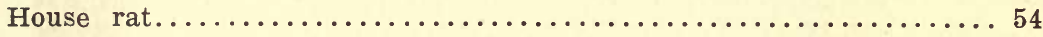

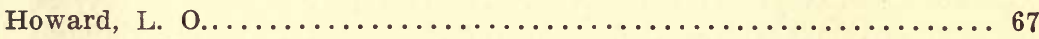

Howell, A. H................................ 154, 155

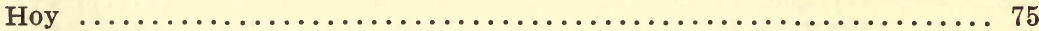

Hudson Bay jumping mouse............................. 151

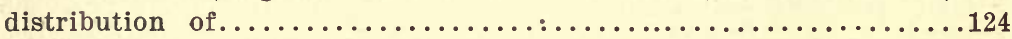

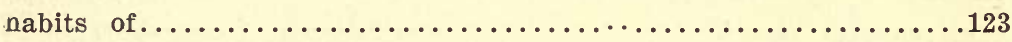

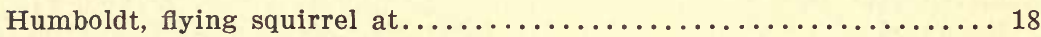

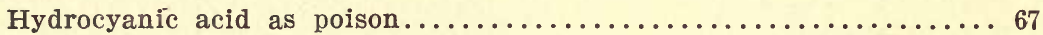

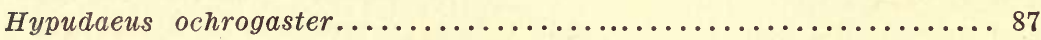

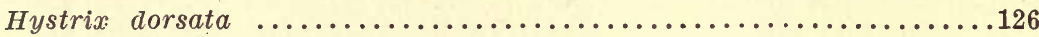

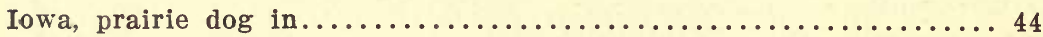

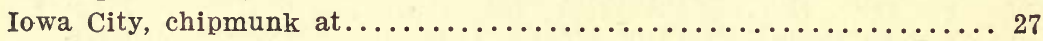

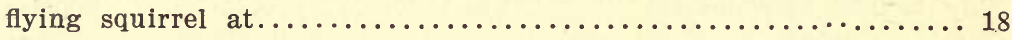

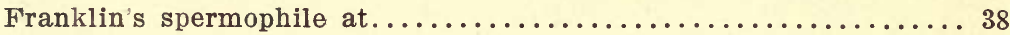

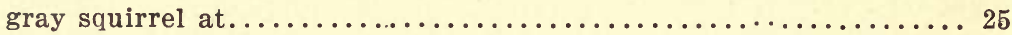

meadow mouse from..$\ldots \ldots \ldots \ldots \ldots \ldots \ldots \ldots \ldots \ldots \ldots \ldots \ldots \ldots$

northern white-footed mouse from....................... 71

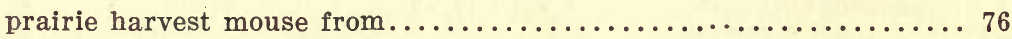

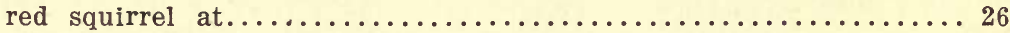

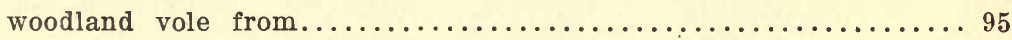

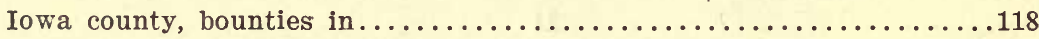

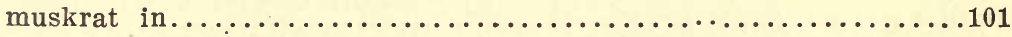

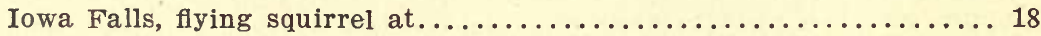

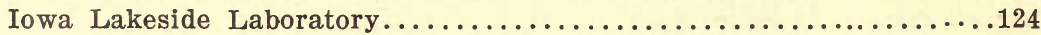




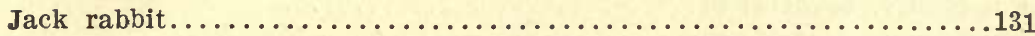

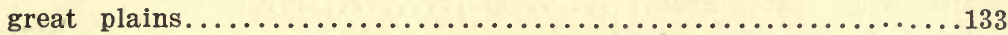

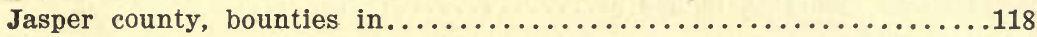

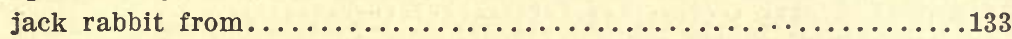

Jefferson, meadow mouse from......................... 81

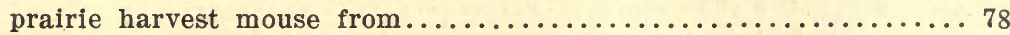

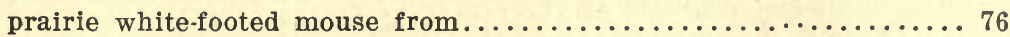

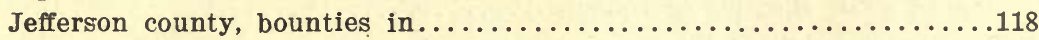

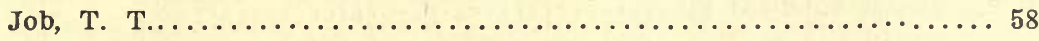

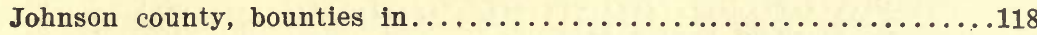

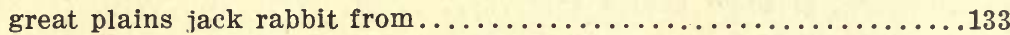

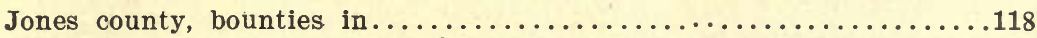

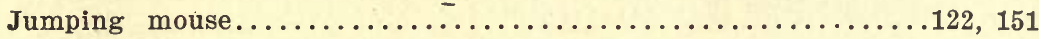

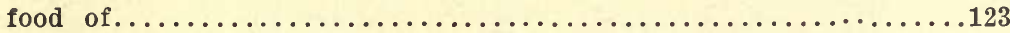

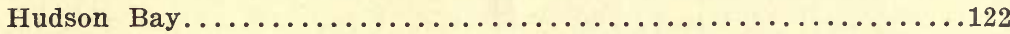

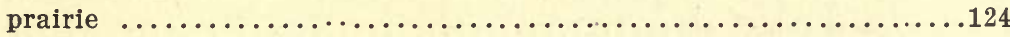

$\mathbf{K}$

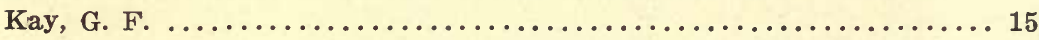

Kennicott, Robert $\ldots \ldots \ldots \ldots \ldots \ldots \ldots \ldots \ldots \ldots \ldots \ldots \ldots \ldots, 75,90,101$

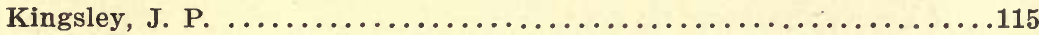

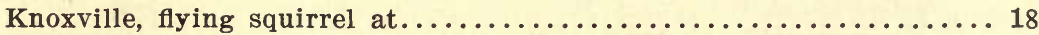

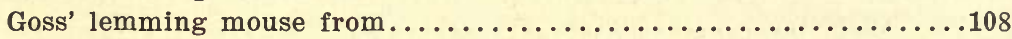

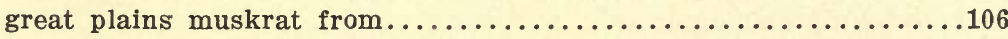

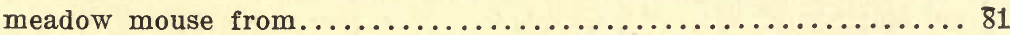

prairig meadow mouse from .......................... 91

prairie white-footed mouse from $\ldots \ldots \ldots \ldots \ldots \ldots \ldots \ldots \ldots \ldots \ldots$

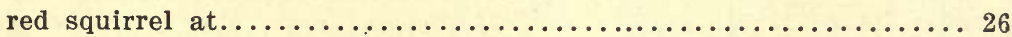

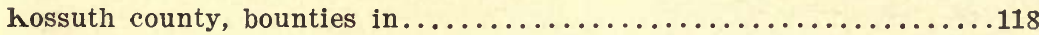

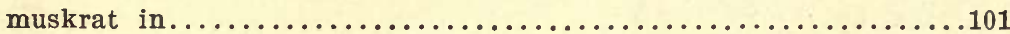

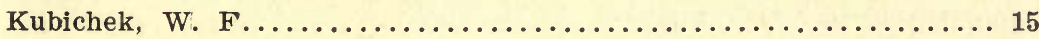

$\mathbf{L}$

Lake Okoboji, Franklin's spermophile at................. 38

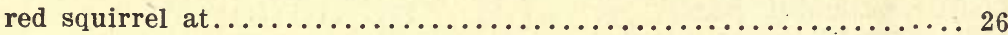

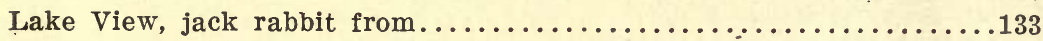

Lantz, D. E............67, 72, 82, 84, 87, 93, 100, 102, 111, 139, 155

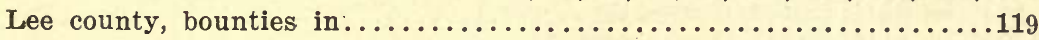

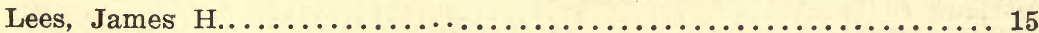

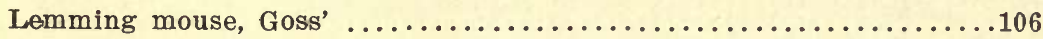

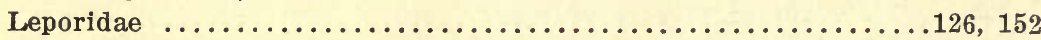

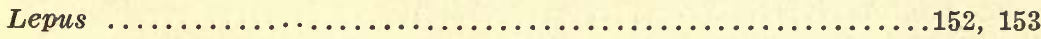

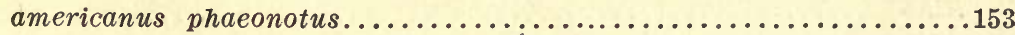

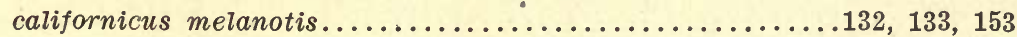

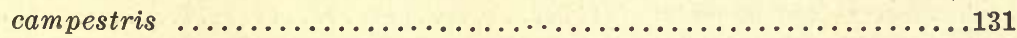

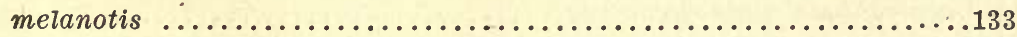

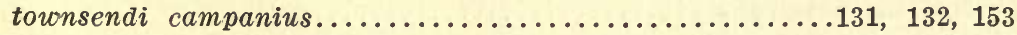

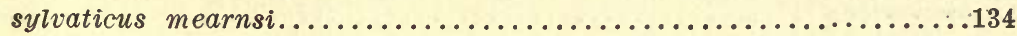


Lime-sulphur wash......................... 86, 139

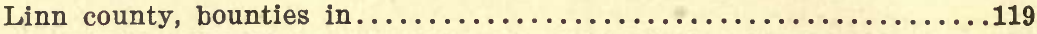

Lizard creek, beaver near............................. 51

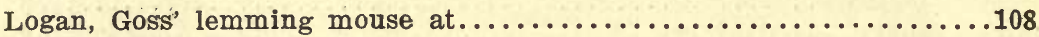

prairie $\operatorname{dog}$ at..................................... 44

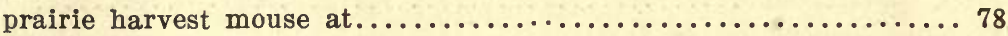

prairie meadow mouse at............................ 91

prairie white-footed mouse at......................... 76

Longeared owls, enemies of rodents............... 85, 137

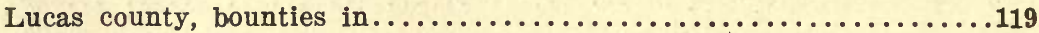

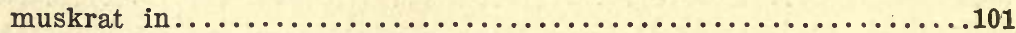

Luxemburg, meadow mouse at....................... 81

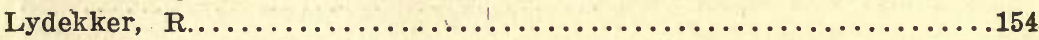

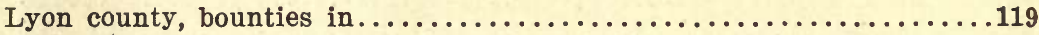

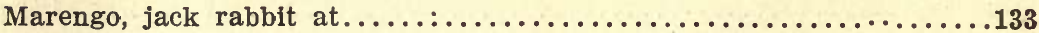

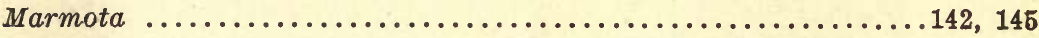

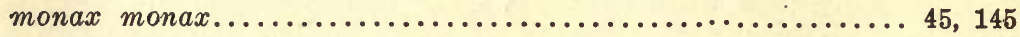

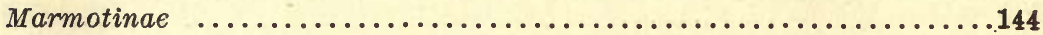

Marsh hawks, enemies of rodents......................... 137

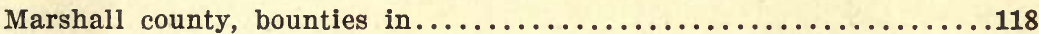

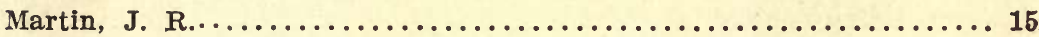

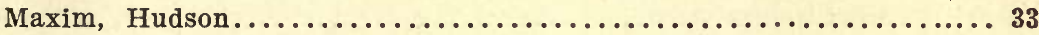

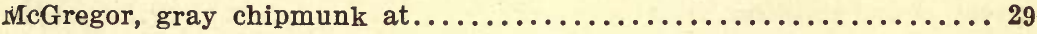

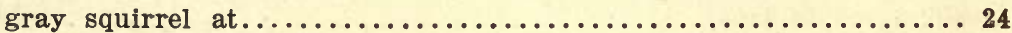

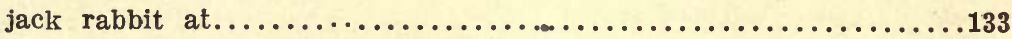

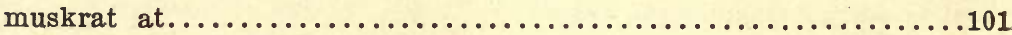

Meadow mouse.............................. 149

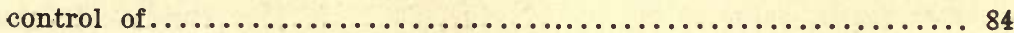

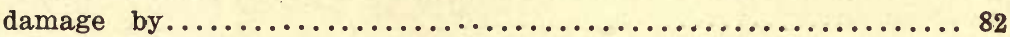

distribution of $\ldots \ldots \ldots \ldots \ldots \ldots \ldots \ldots \ldots \ldots \ldots \ldots \ldots \ldots \ldots \ldots \ldots$

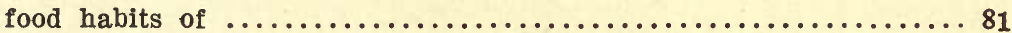

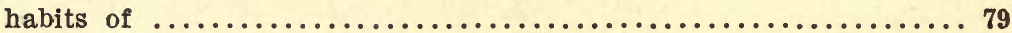

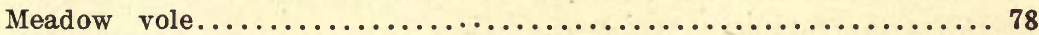

Mearns cottontail rabbit................................... 153

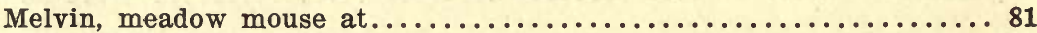

prairie meadow mouse at......................... 91

prairie white-footed mouse at....................... 76

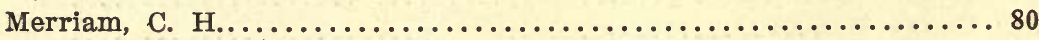

Mice, jumping........................................ 151

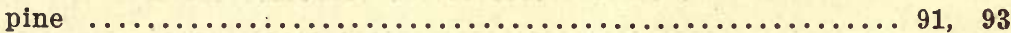

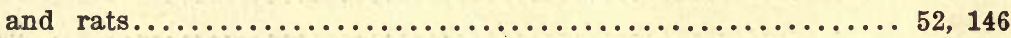

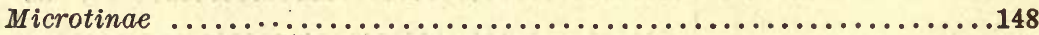

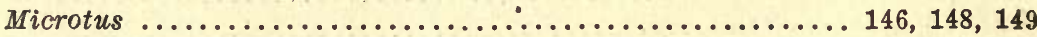

ochrogaster ochrogaster...................... 87, 149

pennsylvanicus pennsylvanicus.................... 78, 149

pinetorum nemoralis .............................. 149

subterraneus $\ldots \ldots \ldots \ldots \ldots \ldots \ldots \ldots \ldots \ldots \ldots \ldots \ldots \ldots \ldots \ldots \ldots \ldots \ldots \ldots$ 
Milford, woodchuck at.............................. 46

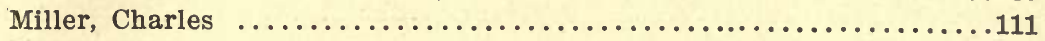

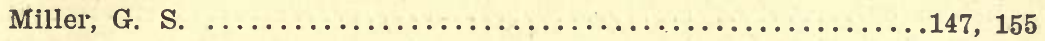

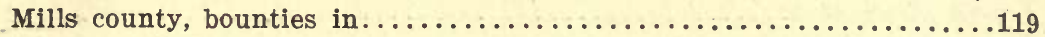

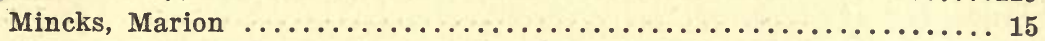

Minks, enemies of rodents.................

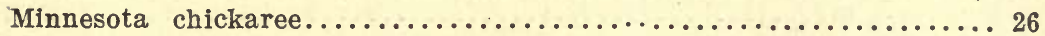

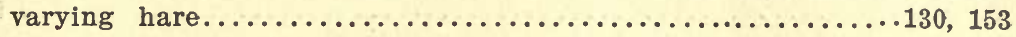

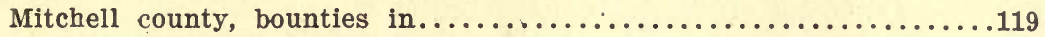

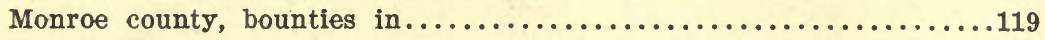

Montgomery county, bounties in...............................

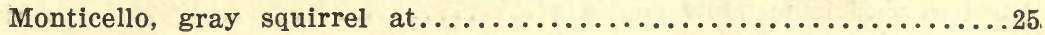

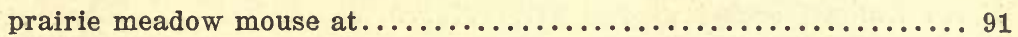

Moody, J. A...................................... 44

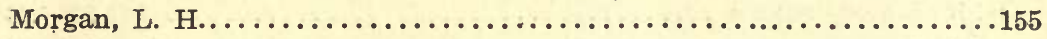

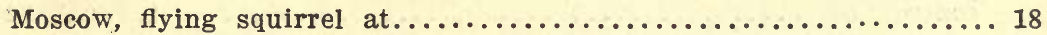

Mount Pleasant, Franklin's spermophile at................ 38

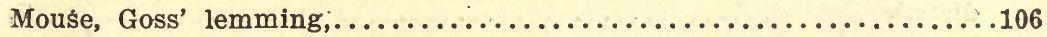

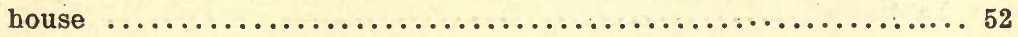

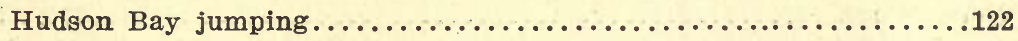

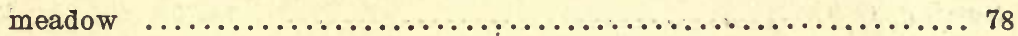

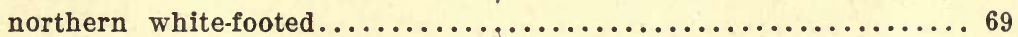

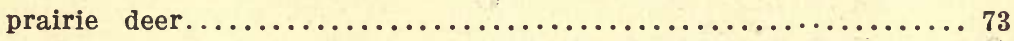

prairie harvest................................ 76

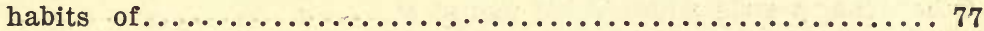

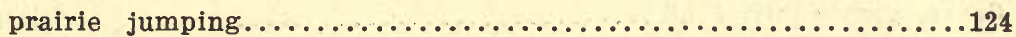

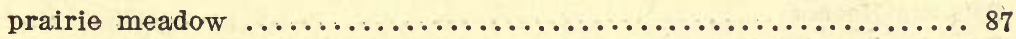

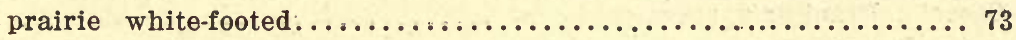

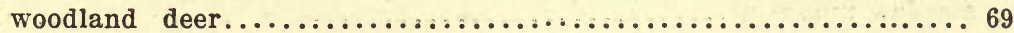

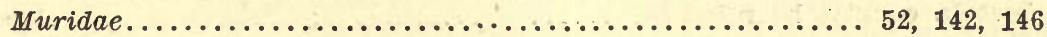

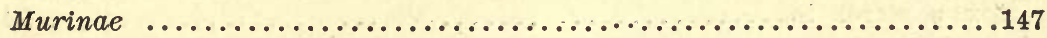

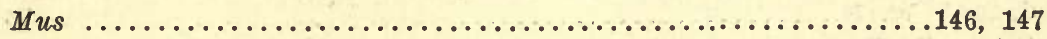

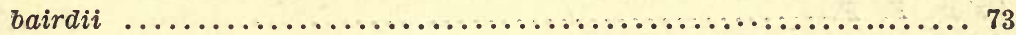

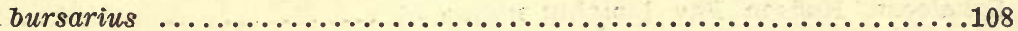

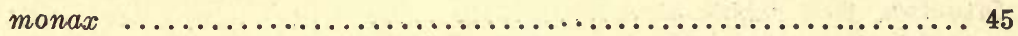

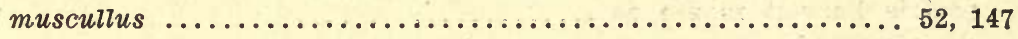

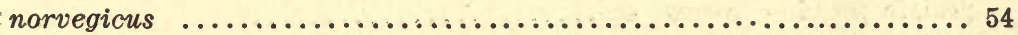

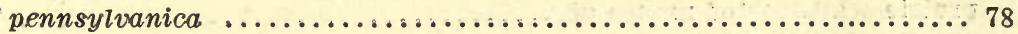

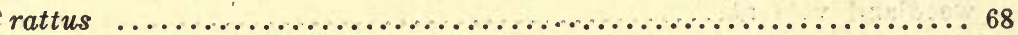

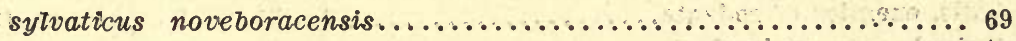

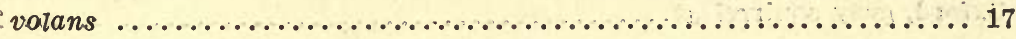

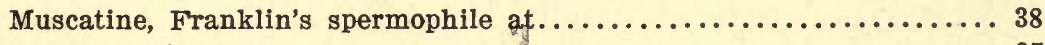

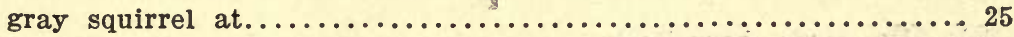

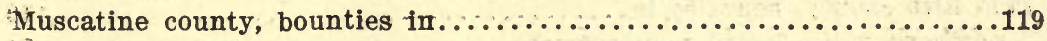

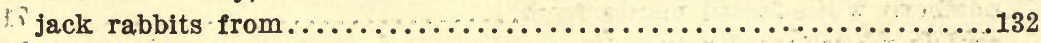

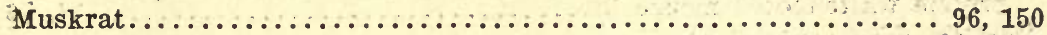

control of $. . \ldots \ldots \ldots \ldots \ldots \ldots \ldots \ldots \ldots \ldots \ldots \ldots \ldots \ldots \ldots \ldots \ldots \ldots \ldots \ldots . .104$

1 damage by .................: : : : : : . : : : : : .........103, 105

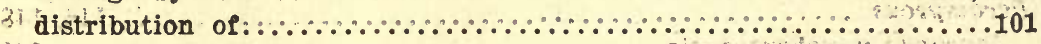

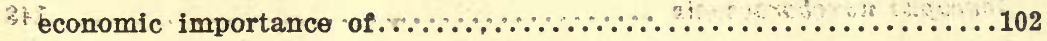




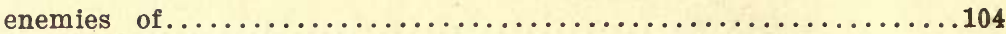

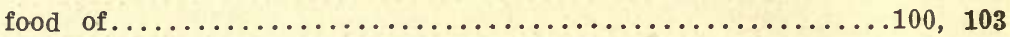

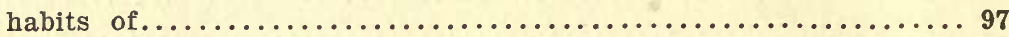

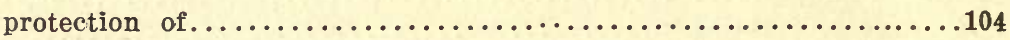

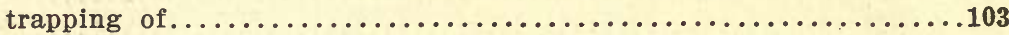

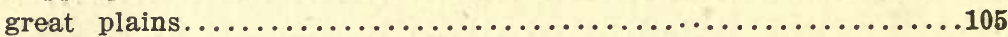

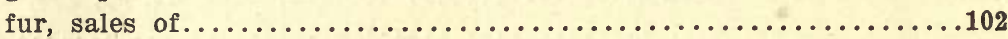

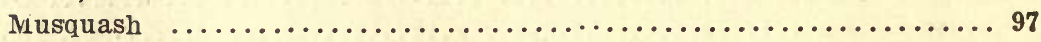

$\mathbf{N}$

Nelson, E. iW........................... 15, 134, 155

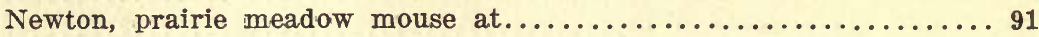

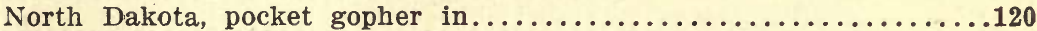

Northern gray squirrel........................ 22, 143

white-footed mouse....................... 63, 148

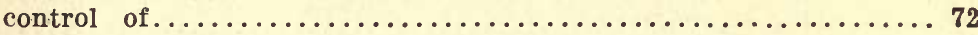

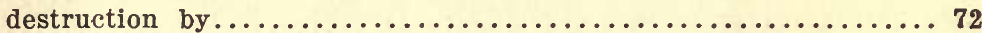

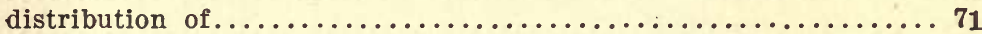

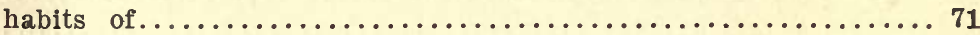

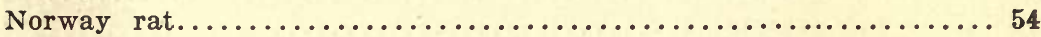

Nutting, C. C...................... 52, 65, 132, 155

$\mathbf{0}$

Oak weevil, destroyed by fox squirrels................... 22

Ocheyedan, prairie white-footed mouse at.................. 76

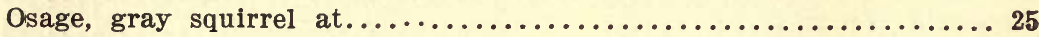

Osborn, Herbert........................... 132, 155

Osceola, Franklin's spermophile at....................... 38

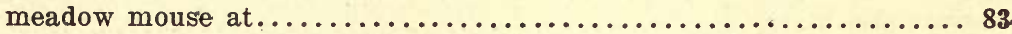

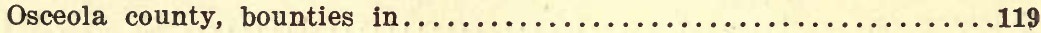

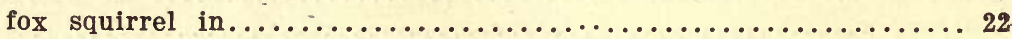

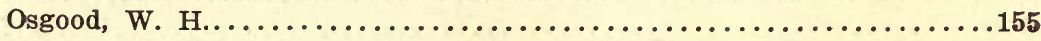

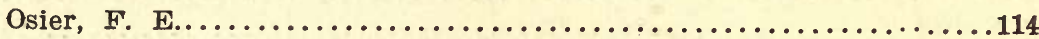

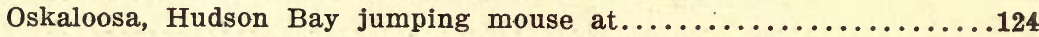

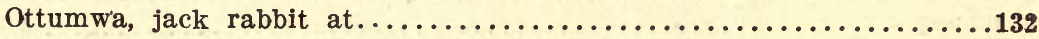

prairie harvest mouse at............................. 78

prairie meadow mouse at. .......................... 91

prairie white-footed mouse at........................ 76

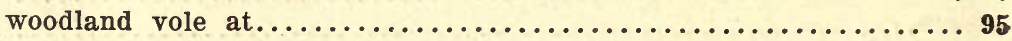

Owls, enemies of rodents.............5. 73, 76, 85, 104, 113, 137

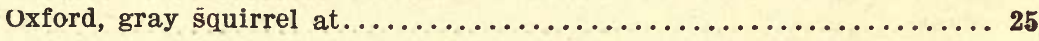

\section{$\mathbf{P}$}

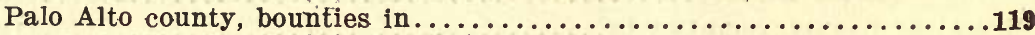

northern white-footed mouse from $\ldots \ldots \ldots \ldots \ldots \ldots \ldots \ldots \ldots \ldots \ldots$

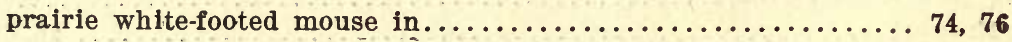

Paralta, gray squirrel at. . . . . . . . . . . . . . 25

Pellett, Frank C............... 15, 19, 44, 46, 53, 78, 111, 130, 134

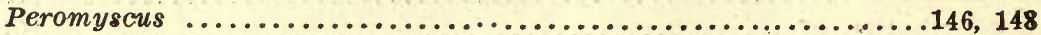

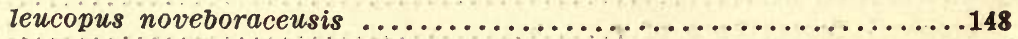


maniculatus bairdi

Phosphorus as poison.

Pine mouse.

food of.

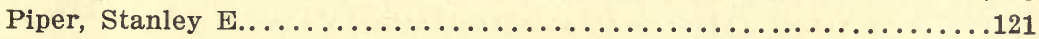

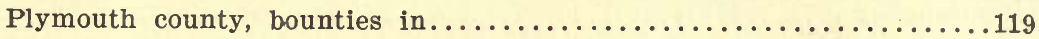

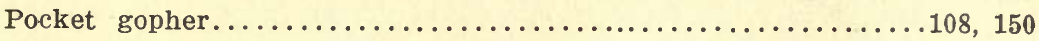

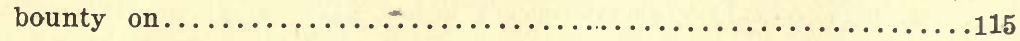

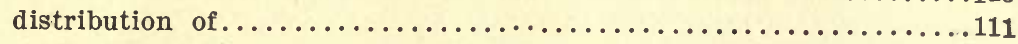

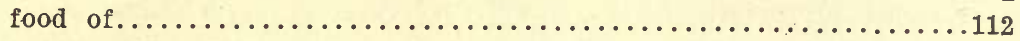

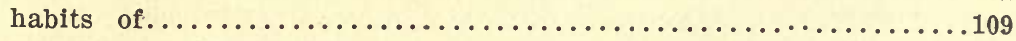

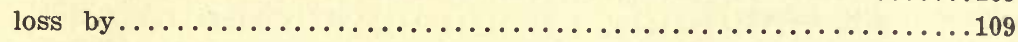

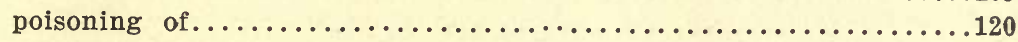

Poison formulæ............................... 42

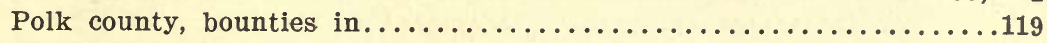

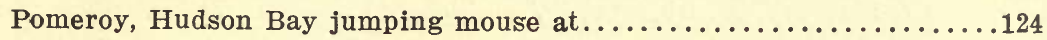

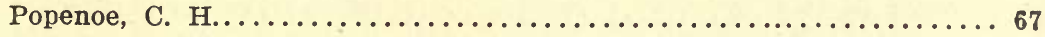

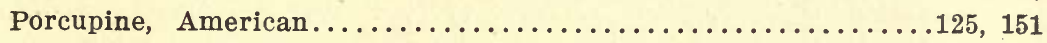

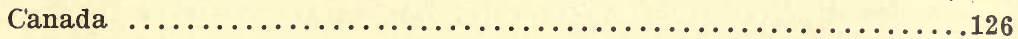

Prairie deer mouse..................................... 73

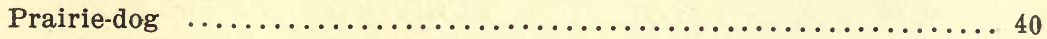

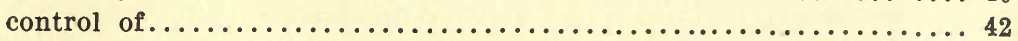

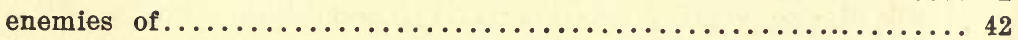

formula of poison for.............................. 42

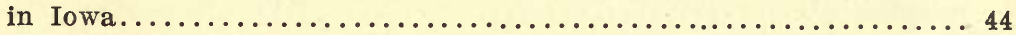

Prairie harvest mouse..................... 10. 107, 148

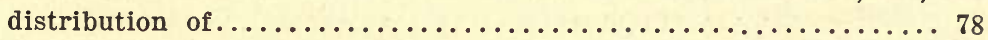

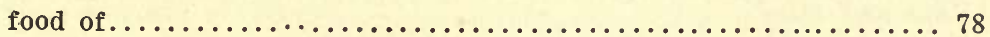

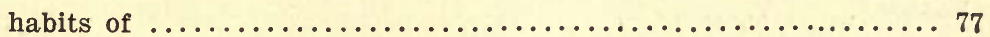

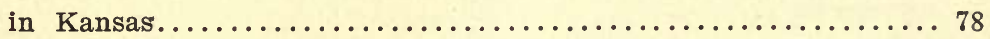

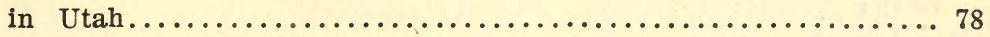

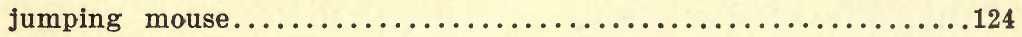

meadow mouse........................... 87, 149

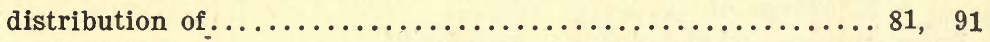

habits of .......................................... 89

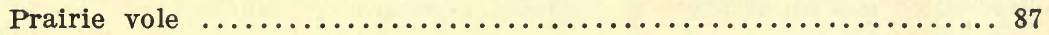

Prairie white-footed mouse................... 53, 73, 148

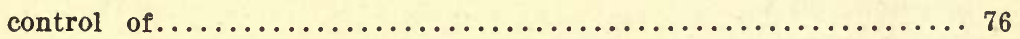

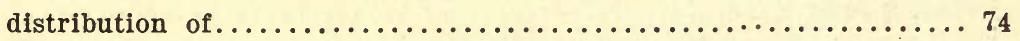

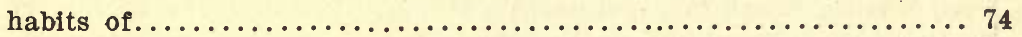

Preble, E. A....................................... 155

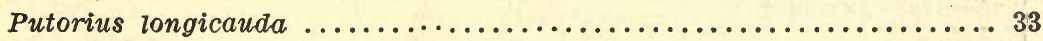

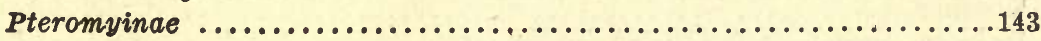

\section{Q}

Quick, E. R............................. 95, 155

\section{$\mathbf{R}$}

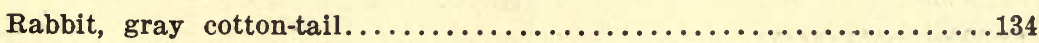

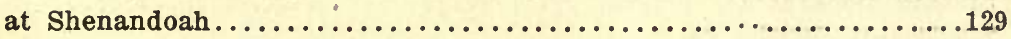




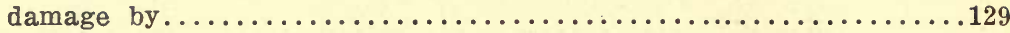

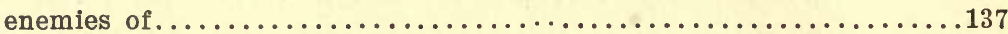

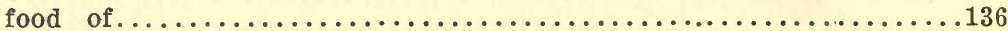

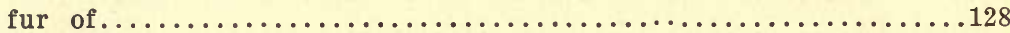

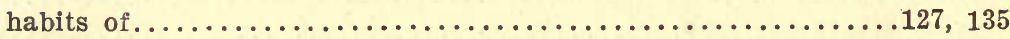

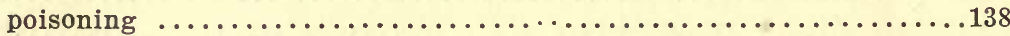

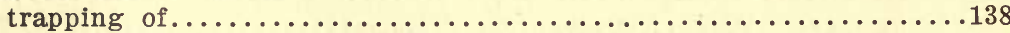

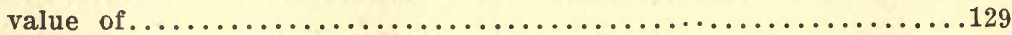

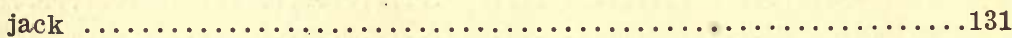

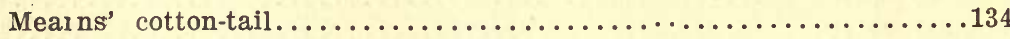

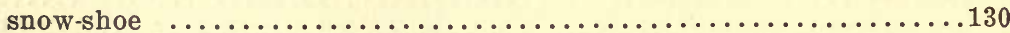

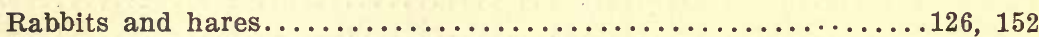

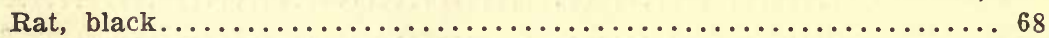

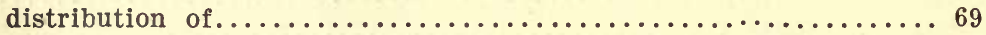

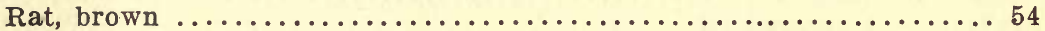

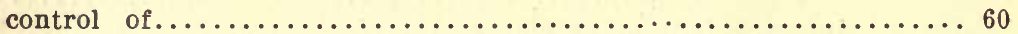

diseases carried by $\ldots \ldots \ldots \ldots \ldots \ldots \ldots \ldots \ldots \ldots \ldots \ldots \ldots \ldots$

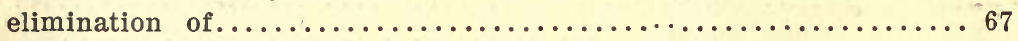

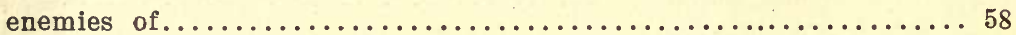

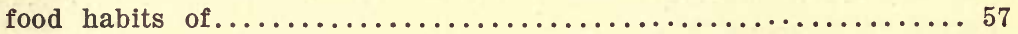

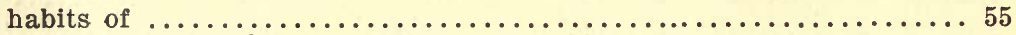

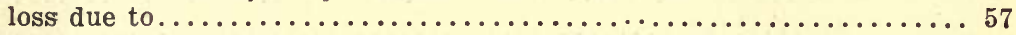

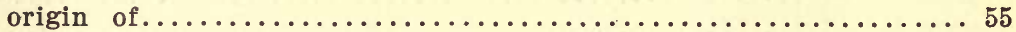

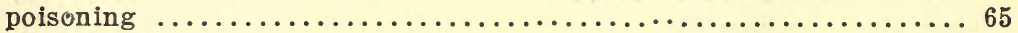

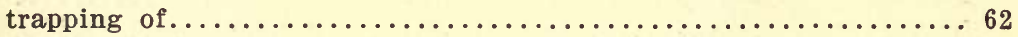

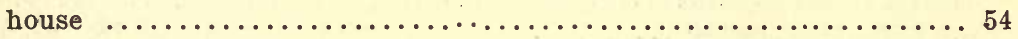

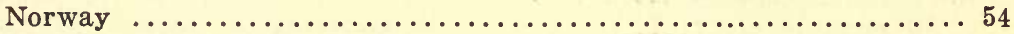

Rats and mice.................................. 146

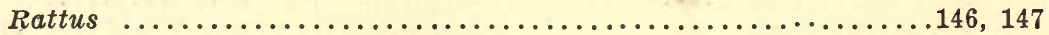

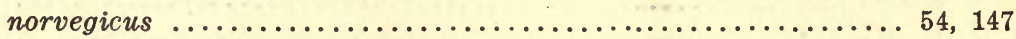

rattus .................................... 147

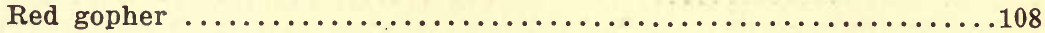

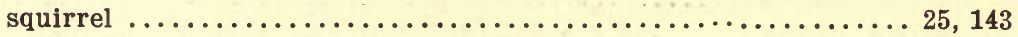

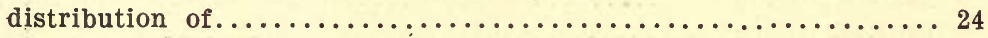

Red-shouldered hawks, enemies of rodents................. 33

Red-tailed hawks, enemies of rodents............. 83, 137

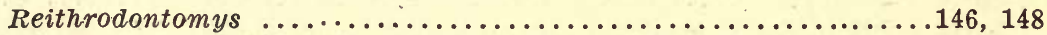

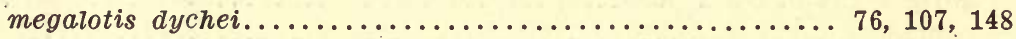

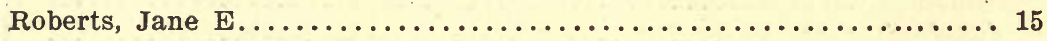

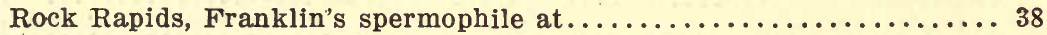

Rockwell City, Franklin's spermophile at.................. 38

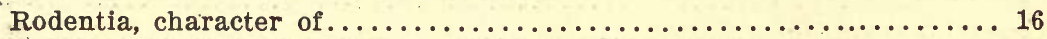

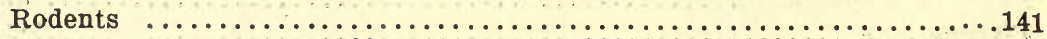

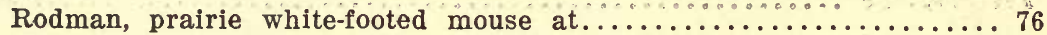

Rough-legged hawks, enemies of rodents.............42, 137

Ruthven, A. G............................ 74, 155

huthven, Franklin's spermophile at..................... 38

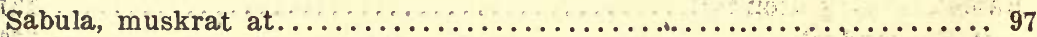

Sac county, beaver in .......................................... 51 


\section{INDEX}

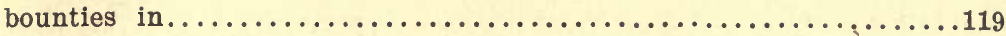

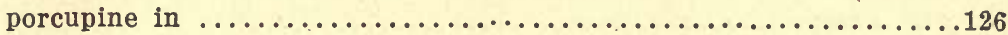

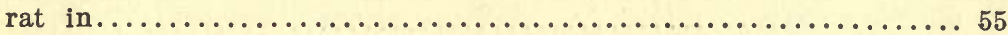

St. Charles county, Missouri, Goss' lemming mouse at.............107

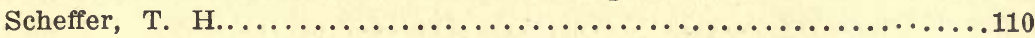

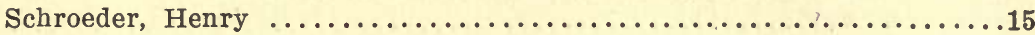

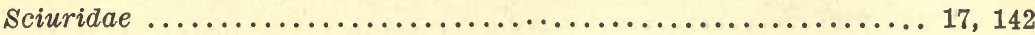

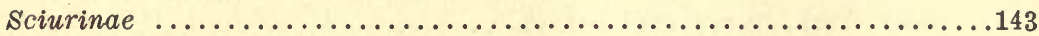

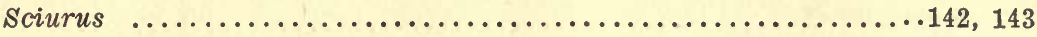

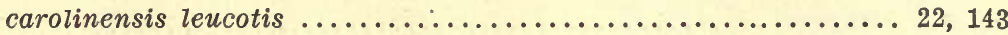

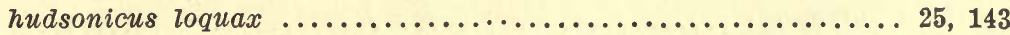

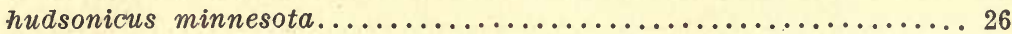

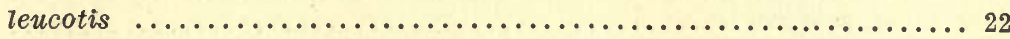

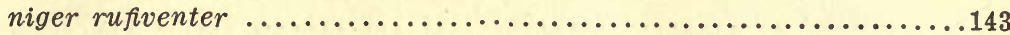

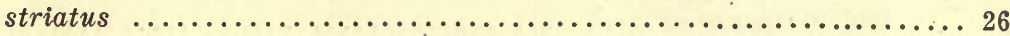

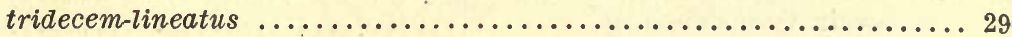

Scott county, bounties in ..................................

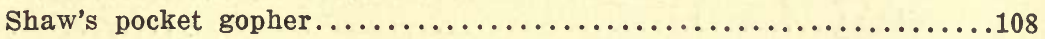

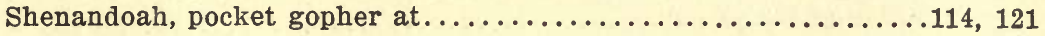

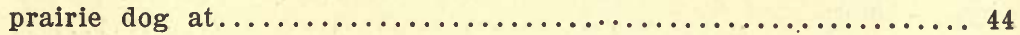

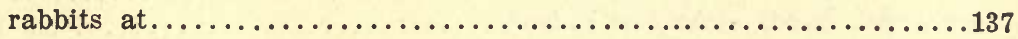

Short-eared owls, enemies of rodents............... 85, 137

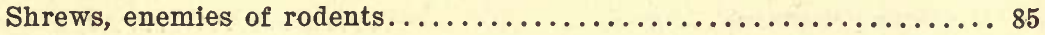

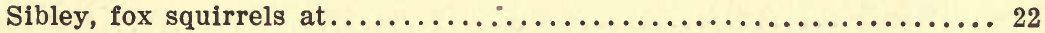

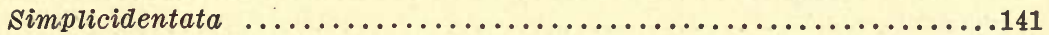

Sioux county, prairie dog in ........................ 44

Skunks, enemies of rodents................. $39,76,85,115$

Snakes, enemies of rodents..................... 73, 76, 114

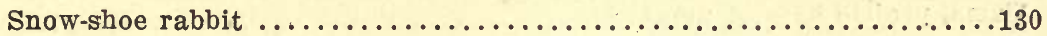

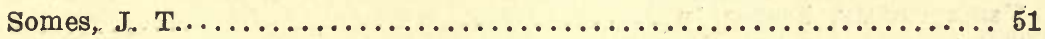

Somes, M. P........................... 44, 51, 133

Southern flying squirrel........................ 17, 143

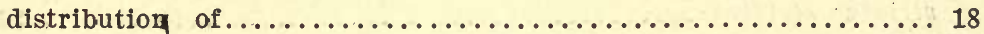

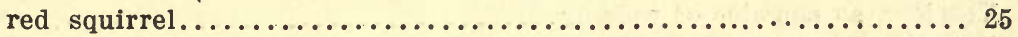

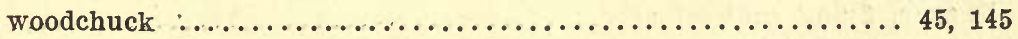

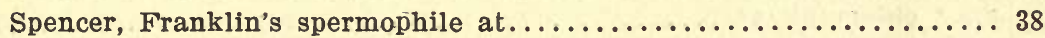

Spermophile ............................... 17, 142

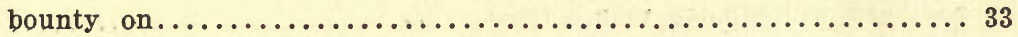

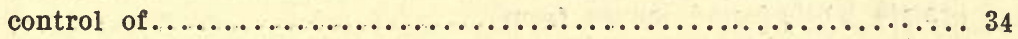

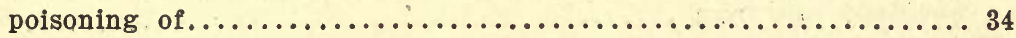

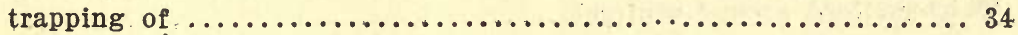

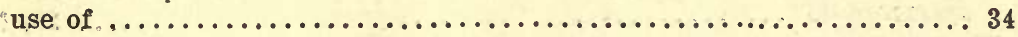

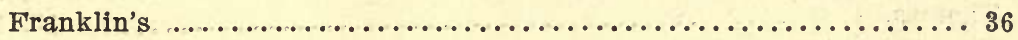

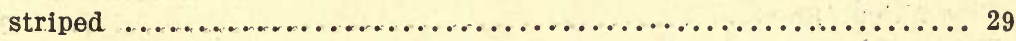

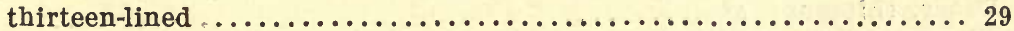

Spurrell, John A.......................15, 22, 51, 55, 102, 126, 133

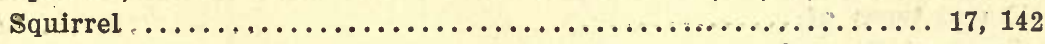

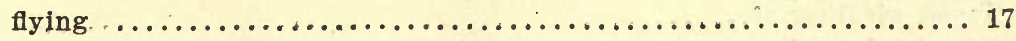

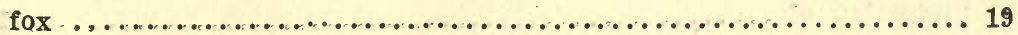

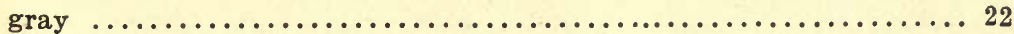


gray ground........................................ 36

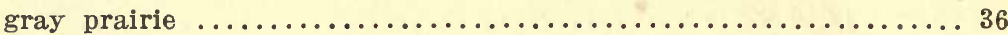

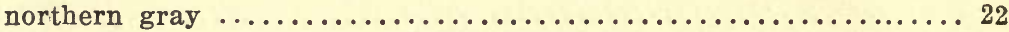

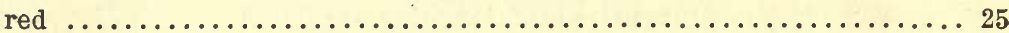

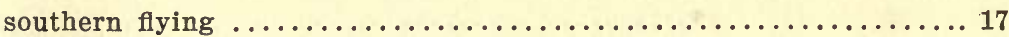

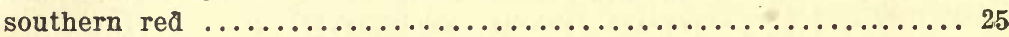

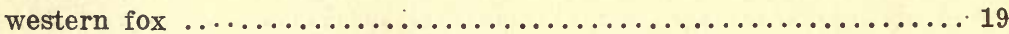

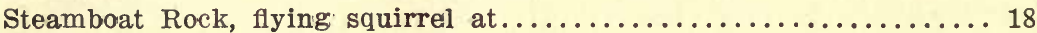

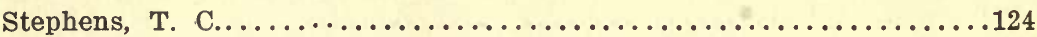

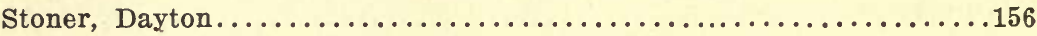

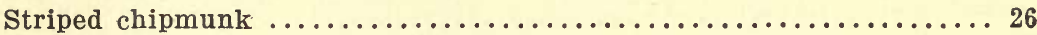

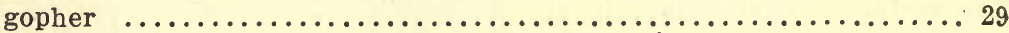

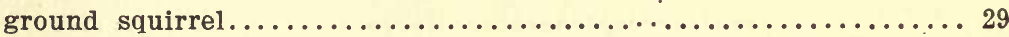

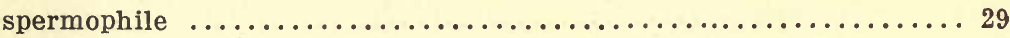

control measures of $\ldots \ldots \ldots \ldots \ldots \ldots \ldots \ldots \ldots \ldots \ldots \ldots \ldots \ldots \ldots \ldots \ldots \ldots$

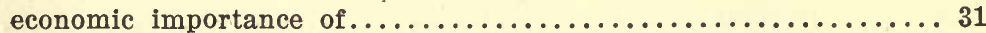

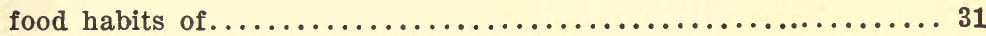

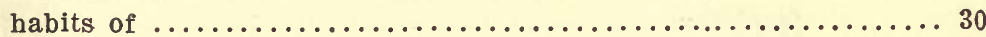

Strychnia sulphate as poison. $\ldots \ldots \ldots \ldots \ldots \ldots \ldots \ldots \ldots, 73,86,138$

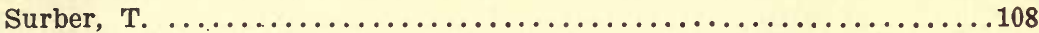

Swainson's hawk, enemy of rodents........................ 137

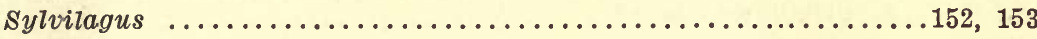

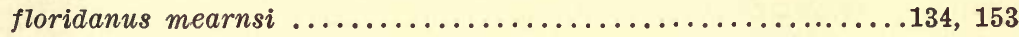

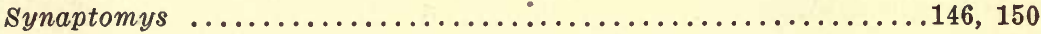

cooperi gossii ............................. 107, 150

\section{$\mathbf{T}$}

Tama, prairie harvest mouse at....................... 78

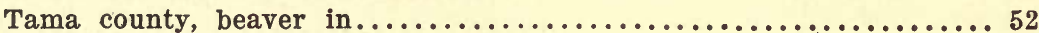

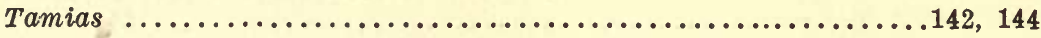

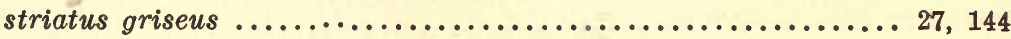

striatus striatus ............................. 26, 144

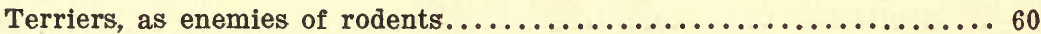

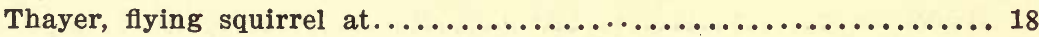

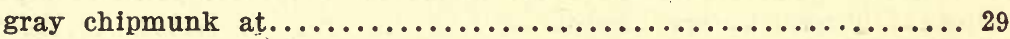

meadow mouse from............................... 81

northern white-footed mouse from ....................... 71

prairie white-footed mouse from $\ldots \ldots \ldots \ldots \ldots \ldots \ldots \ldots \ldots \ldots \ldots$

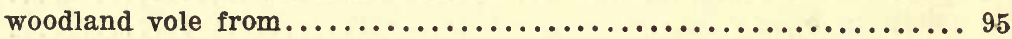

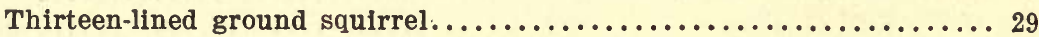

spermophile $\ldots \ldots \ldots \ldots \ldots \ldots \ldots \ldots \ldots \ldots \ldots \ldots \ldots \ldots \ldots \ldots \ldots$. $\ldots \ldots \ldots, 144$

Thomas, A. 0....................................... 111

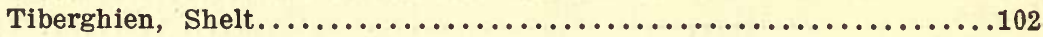

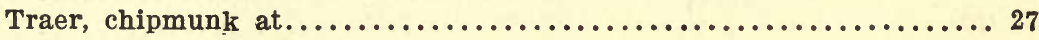

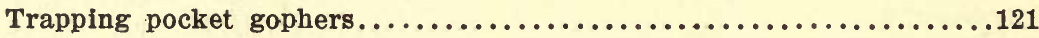

Traps, types of.................................... 62

Trees, girdling of .................................. 86

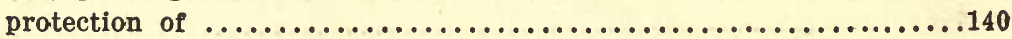


Union county, bounties in ...............................119

United States Biological Survey, work of.................... 14 - Department of Agriculture

$41,43,51,54,62,63,64,72,92,103,109,112,135,136$

Treasury Department................................ 156

\section{$\mathbf{v}$}

Van Hyning, T............................ 126, 130, 156

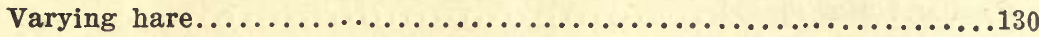

Vinton, prairie white-footed mouse at...................... 75

Vole, meadow ....................................... 78

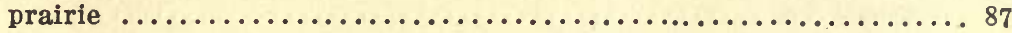

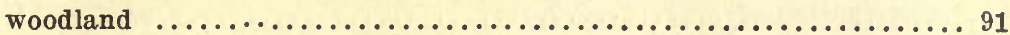

\section{$\mathbf{W}$}

Wall Lake, beaver near................................ 51

flying squirrel at...................................... 18

fox squirrel at........................................ 22

jack rabbit at..........................................

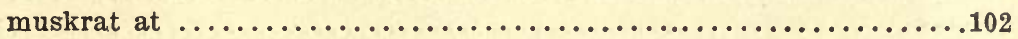

northern white-footed mouse at........................ 71

prairie harvest mouse at............................... 78

prairie meadow mouse at............................. 91

prairie white-footed mouse at........................... 76

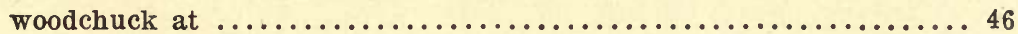

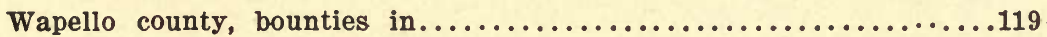

Warren county, bounties in...................................

Waukon, gray squirrei at............................... 24

meadow mouse at.................................... 81

prairie meadow mouse at.............................. 91

prairie white-footed mouse at........................... 76

Wayland, flying squirrel at.............................. 18

gray chipmunk at................................... 29

northern white-footed mouse at.......................... 71

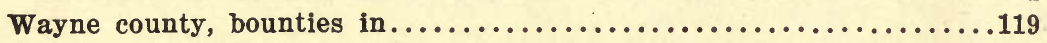

Weasels, enemies of rodents..............33, 59, 73, 76, 85, 115, 137

Welch nursery............................121, 129, 132, 137

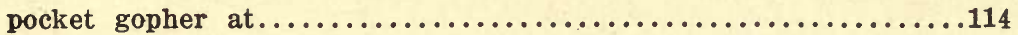

Wellhouse rabbit trap....................................137

West Bend, jack rabbit at................................133

West Liberty, Franklin's spermophile at.................... 38

Western fox squirrel............................... 19, 143

White-footed mouse, northern.......................... 53

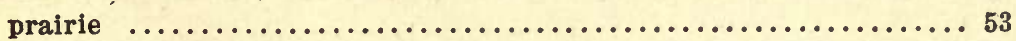

White-tailed jack-rabbit..............................131, 153

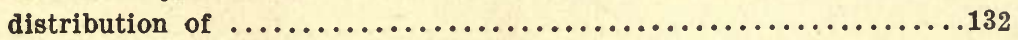

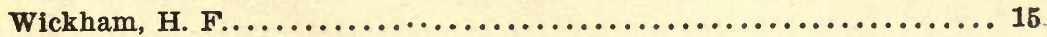

Winnebago county, bounties in..........................119

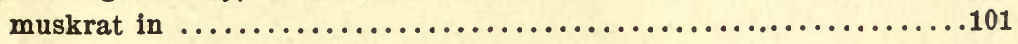


Winneshiek county, bounties in ........................... 119

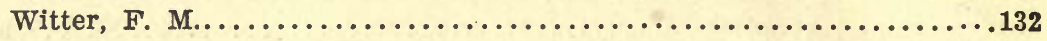

Wolves, enemies of rodents...................... 85, 137

Wood, N. A...................................... 74, 155

Woodbury county, bounties in ............................... 119

Woodchuck .............................. 17, 45, 142

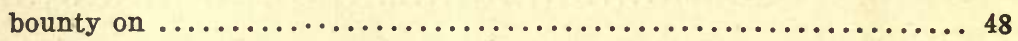

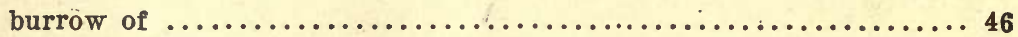

food habits of.$\ldots \ldots \ldots \ldots \ldots \ldots \ldots \ldots \ldots \ldots \ldots \ldots \ldots \ldots \ldots \ldots \ldots$

Woodland deer mouse $\ldots \ldots \ldots \ldots \ldots \ldots \ldots \ldots \ldots \ldots \ldots \ldots \ldots \ldots \ldots . \ldots \ldots 9 . \ldots \ldots$

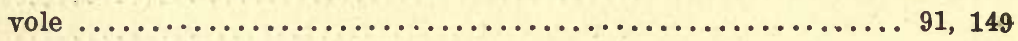

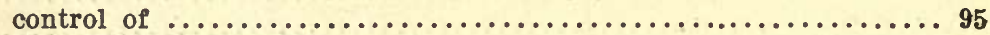

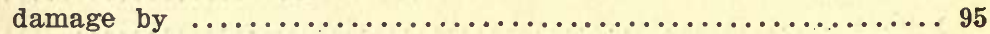

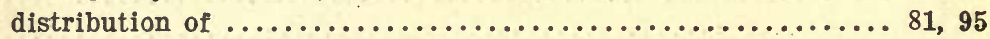

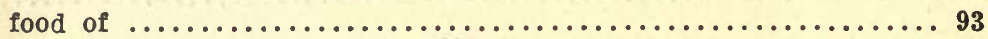

Wright county, bounties in.................................

$\mathbf{Z}$

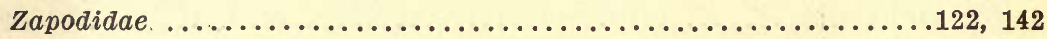

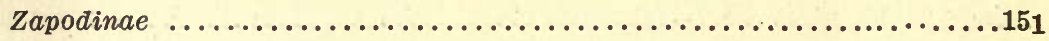

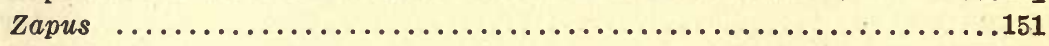

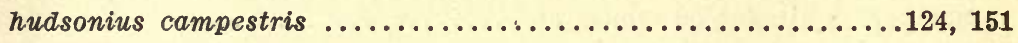

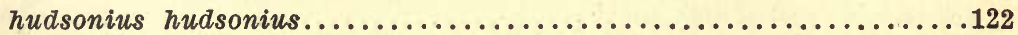








\section{DAY USE}

\section{RETURN TO DESK FROM WHICH BORROWED}

\section{EARTH SCIENCES LIBRARY}

This book is due on the last date stamped below, or on the date to which renewed.

Renewed books are subject to immediate recall.

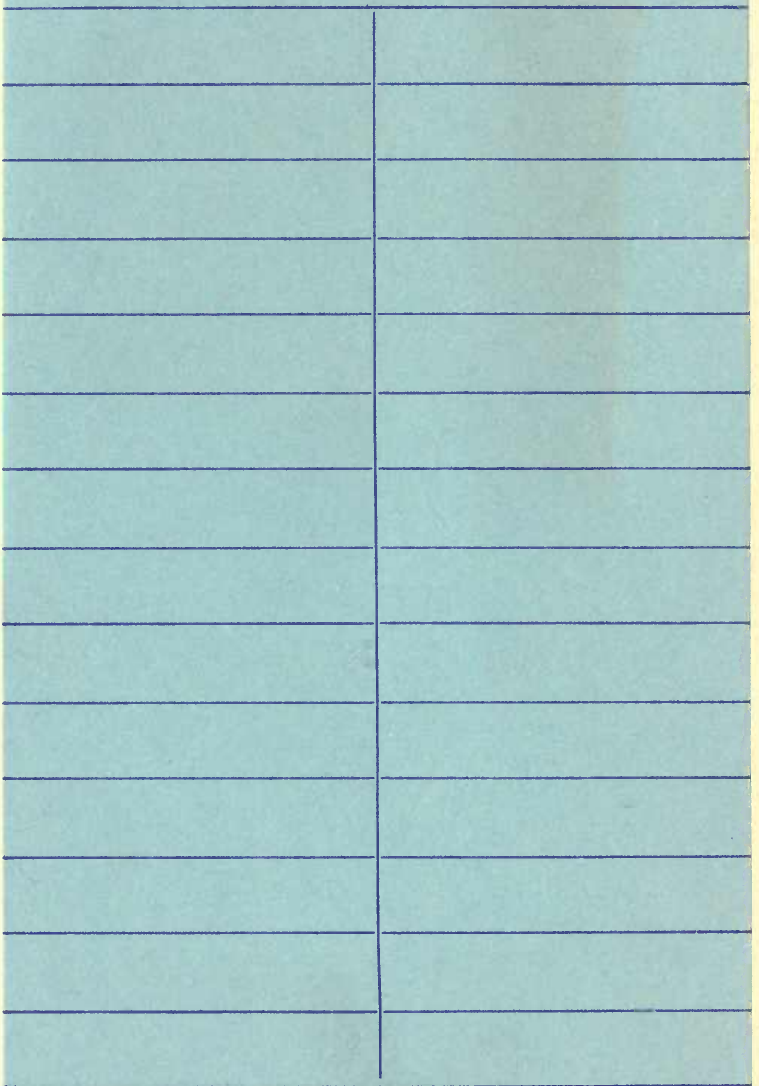




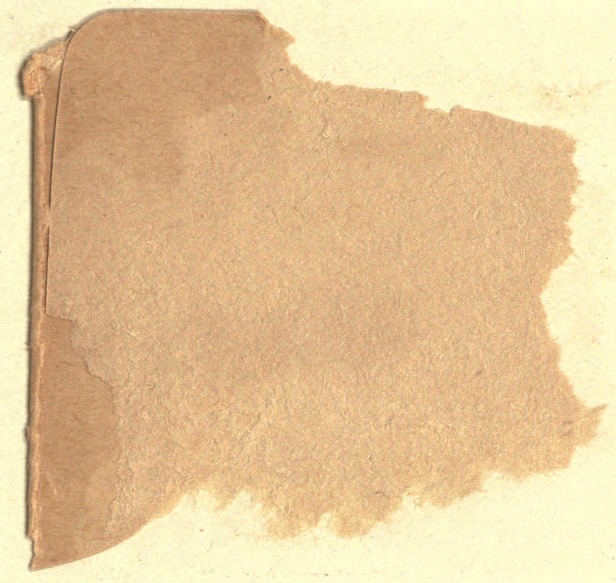




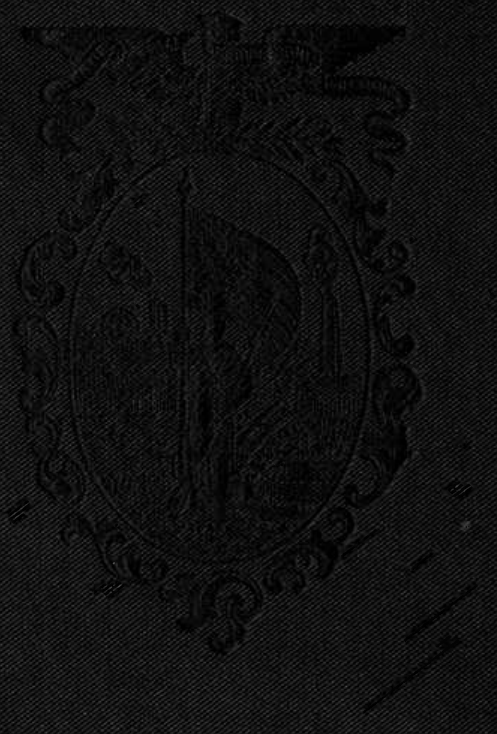

